\title{
BIOGEOMORPHOLOGY OF COASTAL SEAS
}

How benthic organisms, hydrodynamics and sediment dynamics shape tidal sand waves

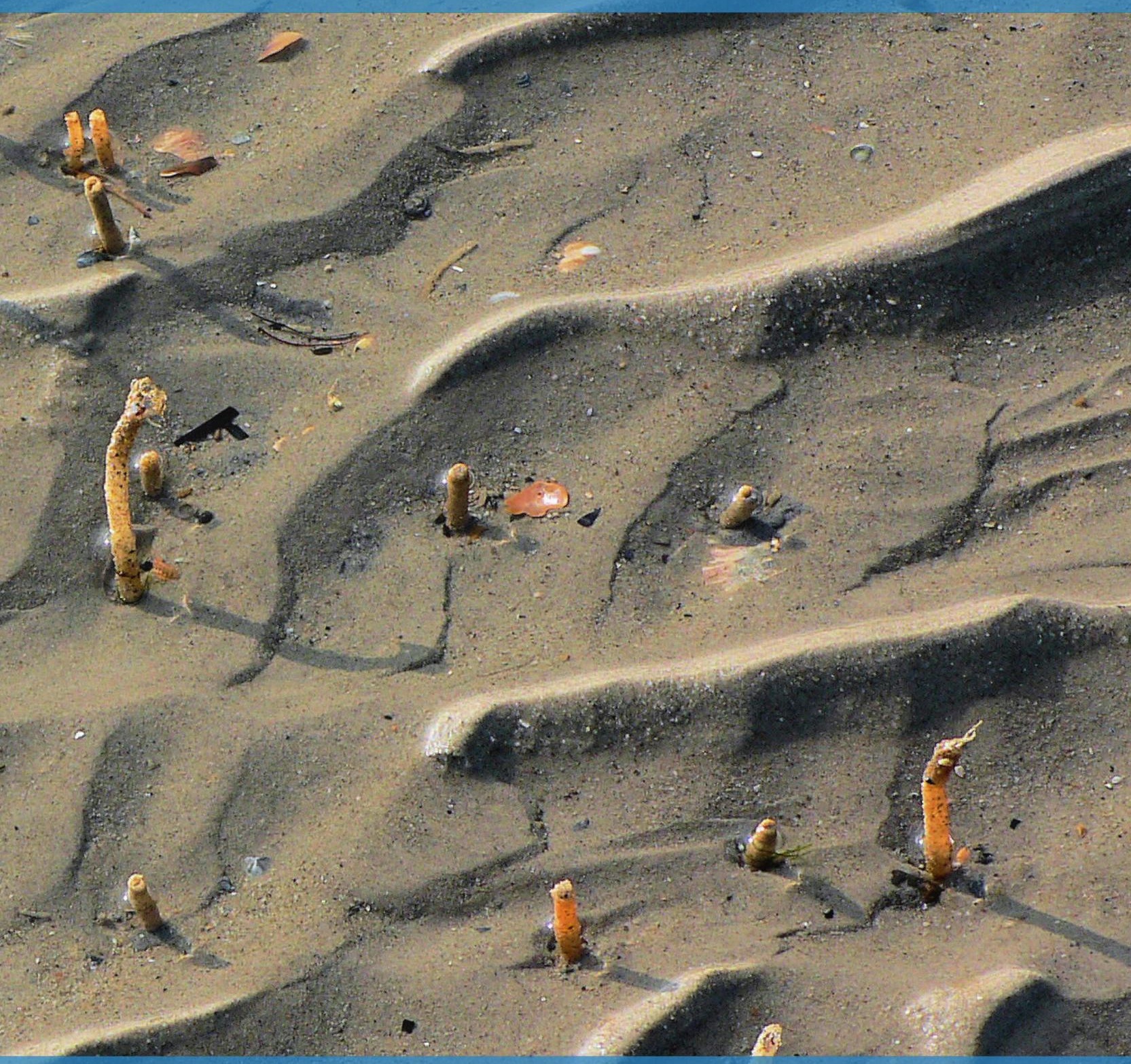

Bas W. Borsje 


\section{BIOGEOMORPHOLOGY OF COASTAL SEAS}

HOW BENTHIC ORGANISMS, HYDRODYNAMICS AND SEDIMENT

DYNAMICS SHAPE TIDAL SAND WAVES 
Promotion committee:

prof. dr. F. Eising

prof. dr. S.J.M.H. Hulscher

prof. dr. P.M.J. Herman

prof. dr. S. Degraer

prof. dr. ir. H. Ridderinkhof

prof. dr. ir. H.J. De Vriend

dr. P. Le Hir

dr. ir. M.J. Baptist

dr. ir. D.C.M. Augustijn
University of Twente, chairman and secretary University of Twente, promotor

Radboud University Nijmegen, promotor

Ghent University

Utrecht University

University of Twente

IFREMER

IMARES

University of Twente

ISBN 978-90-365-3434-5

Copyright (c) 2012 by Bas W. Borsje

Cover: Sand ripples and sand tubes at Studland (UK), courtesy of Jessica Winder Printed by GildePrint, Enschede, The Netherlands 


\title{
BIOGEOMORPHOLOGY OF COASTAL SEAS
}

\author{
HOW BENTHIC ORGANISMS, HYDRODYNAMICS AND SEDIMENT \\ DYNAMICS SHAPE TIDAL SAND WAVES
}

\section{PROEFSCHRIFT}

ter verkrijging van

de graad van doctor aan de Universiteit Twente, op gezag van de rector magnificus, prof. dr. H. Brinksma, volgens besluit van het College voor Promoties in het openbaar te verdedigen op vrijdag 26 oktober 2012 om 16.45 uur

door

Bastiaan Wijnand Borsje geboren op 16 juni 1983 te Ede 
Dit proefschrift is goedgekeurd door de promotoren:

prof. dr. S.J.M.H. Hulscher

prof. dr. P.M.J. Herman 
'...DE ZEE EN IK HADDEN EEN GRANDIOOS GESPREK...'

(ACDA And De Munnik, 1997) 



\section{Contents}

$\begin{array}{ll}\text { Voorwoord } & 11\end{array}$

$\begin{array}{lr}\text { Summary } & 13\end{array}$

$\begin{array}{lr}\text { Samenvatting } & 15\end{array}$

1 Introduction $\quad 17$

1.1 Biogeomorphology of coastal seas . . . . . . . . . . . . . . . 17

1.2 Subtidal seabed patterns . . . . . . . . . . . . . . . . . 19

1.3 Ecosystem engineering species . . . . . . . . . . . . . . . . 19

1.4 Problem formulation . . . . . . . . . . . . . . . . . . 21

1.5 Research approaches: field observations, flume experiments and model studies . . . . . . . . . . . . . . . . . . . 21

1.6 Understanding tidal sand wave formation . . . . . . . . . . . . 23

1.7 Objectives and research questions . . . . . . . . . . . . . . . . . 24

1.8 Outline of the thesis . . . . . . . . . . . . . . . . . . . 24

2 Modeling tidal sand wave formation in a numerical shallow water $\begin{array}{lr}\text { model } & 27\end{array}$

2.1 Introduction . . . . . . . . . . . . . . . . . . . 28

2.2 Model description . . . . . . . . . . . . . . . . . . . . . . 30

2.2 .1 Hydrodynamics . . . . . . . . . . . . . . . . . . . . 30

2.2.2 Sediment transport and bed evolution . . . . . . . . . . 31

2.2 .3 Model set-up . . . . . . . . . . . . . . . . . . . 32

2.3 Results . . . . . . . . . . . . . . . . . . . . . . 33

2.3 .1 Hydrodynamics . . . . . . . . . . . . . . . . . . . . . 33

2.3 .2 Bed evolution . . . . . . . . . . . . . . . . 35

2.3 .3 Migration . . . . . . . . . . . . . . . . . . . 37

2.4 Comparison model results and field data . . . . . . . . . . . . . 40

2.5 Discussion . . . . . . . . . . . . . . . . . . . . . . . . 4 41

2.6 Conclusions . . . . . . . . . . . . . . . . . . . . 44

3 The role of suspended load transport in the occurrence of tidal sand $\begin{array}{ll}\text { waves } & 45\end{array}$

3.1 Introduction . . . . . . . . . . . . . . . . . . . 46

3.2 Field data on sand wave occurrence and transport regime . . . . . . . . 47

3.3 Model description . . . . . . . . . . . . . . . . . . . . . 50

3.3 .1 Hydrodynamics . . . . . . . . . . . . . . . . . . . 50

3.3.2 Sediment transport and bed evolution . . . . . . . . . . 51 
3.3 .3 Model set-up . . . . . . . . . . . . . . . . . . . . . 52

3.4 Results . . . . . . . . . . . . . . . . . . . . . 54

3.4 .1 Sediment transport rates . . . . . . . . . . . . 54

3.4 .2 Bed evolution . . . . . . . . . . . . . 57

3.4.3 Critical conditions for sand wave generation . . . . . . . . 59

3.5 Discussion . . . . . . . . . . . . . . . 60

3.6 Conclusions . . . . . . . . . . . . . . . . . . . . 61

4 Modeling biogeomorphological influences for offshore sand waves 63

4.1 Introduction . . . . . . . . . . . . . . . . . . . 64

4.2 Offshore environment of the Dutch Coast . . . . . . . . . . . . . . . 64

4.3 Impact of subtidal biota on sediment dynamics and hydrodynamics . . . 68

4.4 Modeling the role of biogeomorphological influences on seabed patterns $\quad 70$

4.4.1 Parameterization of biological activity . . . . . . . . . . 72

4.4 .2 Modeling results . . . . . . . . . . . . . . . . 74

4.5 Discussion . . . . . . . . . . . . . . . . . 77

4.6 Conclusions . . . . . . . . . . . . . . . . . . . . 79

5 On the paramaterization of biological influences on offshore sand wave $\begin{array}{lr}\text { dynamics } & 81\end{array}$

5.1 Introduction . . . . . . . . . . . . . . . . . . . 82

5.2 Parameterization of biological activity . . . . . . . . . . . 82

5.2.1 Tube-building worm - Lanice conchilega . . . . . . . . . . . 84

5.2 .2 Bivalve - Tellina fabula . . . . . . . . . . . . 86

5.2.3 Sea urchin - Echinocardium cordatum . . . . . . . . . 87

5.3 Modeling biogeomorphological interactions for offshore sand waves . . . 88

5.3.1 Biogeomorphological model description . . . . . . . . . . . 88

5.3 .2 Study area . . . . . . . . . . . . . . . . . . 92

5.3 .3 Results . . . . . . . . . . . . . . . . . . . 94

5.4 Discussion . . . . . . . . . . . . . . . . 96

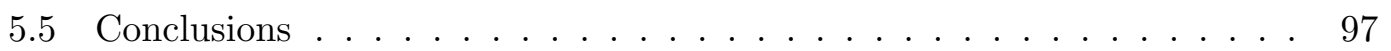

6 Creation and degradation rates of biogeomorphological structures: a $\begin{array}{lr}\text { study on the tube-building polychaete Lanice conchilega } & 99\end{array}$

6.1 Introduction . . . . . . . . . . . . . . . . . . . 100

6.2 Material and Methods . . . . . . . . . . . . . . . . . . . 102

6.2.1 Flume experiments for model validation . . . . . . . . . . . . . 102

6.2 .2 Model set-up . . . . . . . . . . . . . . . . . . 103

6.2.3 Distinguishing the dominant transport mode by Rouse number . 107

6.3 Results . . . . . . . . . . . . . . . . . . . . 107

6.3.1 Hydrodynamic effects of patches - measurements \& modeling . . 107

6.3.2 Modeling geomorphodynamics of patches - biological factors . . . 110

6.3.3 Modeling geomorphodynamics of patches - physical factors . . . 110

6.3.4 Modeling geomorphodynamics of patches - degradation . . . . . 113

6.4 Discussion and Conclusions . . . . . . . . . . . . . . . . . . 113 
7 Modeling bio-physical influences on seasonal variation in sand wave $\begin{array}{lr}\text { dynamics } & 117\end{array}$

7.1 Introduction . . . . . . . . . . . . . . . . . . 118

7.2 Study area. . . . . . . . . . . . . . . . . . . . . . . . 119

7.3 Data and model set-up . . . . . . . . . . . . . . . . 120

7.4 Results . . . . . . . . . . . . . . . . . . . . . . . 122

7.5 Discussion . . . . . . . . . . . . . . . . . . . . . . . . . . 124

7.6 Conclusions . . . . . . . . . . . . . . . . . . . . . . 125

8 Self-organization in the underwater landscape: exploring bio-physical $\begin{array}{lr}\text { interactions in tidal sand wave fields } & 127\end{array}$

8.1 Introduction . . . . . . . . . . . . . . . . . . . . 128

8.2 Model . . . . . . . . . . . . . . . . . . . . . . . . 130

8.2.1 Schematized sand wave model . . . . . . . . . . . . . 130

8.2.2 Self-organizational sand wave model . . . . . . . . . . . . . 131

8.2 .3 Bio-dynamic sand wave model . . . . . . . . . . . . . . . . 132

8.3 Model Results . . . . . . . . . . . . . . . . . . . . . . . . . . 133

8.3.1 Schematized sand wave model . . . . . . . . . . . . . . 133

8.3.2 Self-organizational sand wave model . . . . . . . . . . . . . . . 134

8.3.3 Bio-dynamic sand wave model . . . . . . . . . . . . . 138

8.4 Discussion . . . . . . . . . . . . . . . . . . . . . . . 140

8.5 Conclusions . . . . . . . . . . . . . . . . . . . . . . . . . . 141

9 Discussion and Conclusions 143

9.1 Discussion . . . . . . . . . . . . . . . . . . . . . . 143

9.1.1 Understanding the formation of landscapes . . . . . . . . . . . 143

9.1.2 Biogeomorphological interactions in landscape formation . . . . . 145

9.1.3 Validation of biogeomorphological interactions . . . . . . . . . 146

9.1.4 Impact of anthropogenic influences on the coupled system . . . . 147

9.2 Conclusions . . . . . . . . . . . . . . . . . . . . . . . 148

$\begin{array}{ll}\text { Bibliography } & 151\end{array}$

$\begin{array}{ll}\text { List of publications } & 165\end{array}$

$\begin{array}{lr}\text { About the author } & 169\end{array}$ 


\section{Voorwoord}

De zee en ik hebben altijd al een bijzondere band gehad. In mijn jeugd heb ik uren aan het strand gespeeld tegen en met het water. Hoe eb en vloed veroorzaakt worden en waarom golven breken, daar hield ik me toen niet mee bezig: ik genoot gewoon! Jaren later toen ik Civiele Techniek ging studeren begon ik de fysica te verklaren en te begrijpen en begon ik het leuk te vinden om de interactie tussen organismen, water en zand te onderzoeken. Ik vond het daarom ook erg leerzaam om tijdens mijn afstudeerscriptie bezig te zijn met deze interactie, en daarom wil ik als eerste Mindert de Vries bedanken voor de kans die hij mij gaf om bij WL|Delft Hydraulics hiermee aan de slag te gaan. Jouw enthousiaste manier van begeleiden, vragen stellen, meedenken en meeleven hebben de basis gelegd voor het onderwerp van mijn promotieonderzoek.

Toen Suzanne Hulscher mij vervolgens de vraag stelde om te promoveren binnen haar groep was de keuze snel gemaakt. Suzanne, ik wil je bedanken voor het vertrouwen in mijn onderzoek en het stimuleren om steeds weer de grens van het bekende te verleggen. Mede hierdoor zie ik er ook naar uit om de komende tijd onderdeel uit te blijven maken van de vakgroep in Twente. Tijdens mijn onderzoek heb ik tevens het voorrecht gehad om begeleid te worden Peter Herman. Peter, je bent een inspirator voor een hele generatie onderzoekers en ik ben nog steeds verbaasd door de snelheid en grondigheid waarmee jij manuscripten van commentaar voorziet en waardoor ik zo trots kan zijn op dit proefschrift.

Met veel verschillende mensen heb ik het kantoor gedeeld in Twente en hierdoor heb ik heel veel geleerd en werkplezier gehad. Speciaal wil ik Jord bedanken voor zijn stimulans om dit boekje op deze manier op te maken en zijn zeer waardevolle rol hierin.

Tijdens mijn promotieonderzoek ben ik één dag in de week blijven werken voor WL|Delft Hydraulics, dat later Deltares werd. Deze combinatie heeft ervoor gezorgd dat ik makkelijk toegang had tot data en modellen en dat ik mijn onderzoeksresultaten snel kon delen met experts in het vakgebied. Ik wil graag Tom Schilperoort en Sharon Tatman bedanken voor hun vertrouwen in mij en de mogelijkheid om op deze manier mijn werk te combineren. Daarnaast wil ik de collega's van de afdeling WQE bedanken die mij steeds weer de motivatie gaven om de lange reis tussen Twente en Delft af te leggen. Ook mooi om te zien dat onze afdeling steeds beter in staat is om verschillende vakgebieden te verbinden en het is goed om te beseffen welke mogelijkheden dit blijft geven in de toekomst!

Daarnaast wil ik de leden van mijn gebruikersgroep bedanken voor hun waardevolle feedback tijdens de vergaderingen en input in alle papers die uiteindelijk tot stand zijn gekomen. Tevens wil ik alle co-auteurs bedanken voor de input in de verschillende papers. Het was een hele beleving om op allerlei verschillende plekken op de wereld ontvangen te worden en te ontdekken dat overal met evenveel passie onderzoek wordt gedaan naar de interactie tussen organismen, water en zand. 
De afgelopen jaren bestond het leven niet alleen uit onderzoek doen en daarom ben ik heel veel vrienden bijzonder dankbaar voor de afleiding die zij mij hebben gegeven op momenten dat ik niet in de trein, in het veld of op kantoor was. Ik ben bijzonder blij dat jullie aanwezig kunnen zijn bij de verdediging en dit belangrijke moment met mij mee kunnen vieren. Jullie zijn onderdeel van dit succes!

Dat ik tijdens de verdediging word bijgestaan door Wouter en Matthijs is een hele eer. Wouter, de vele lunchwandelingen en discussies waren een enorme stimulans voor mij en hebben zeker bijgedragen aan het plezier in het onderzoek. Matthijs, de komende jaren op afstand, maar de keren dat wij elkaar zien wordt het leven gevierd en haal je steeds het beste in mij naar boven.

Mijn ouders wil ik bedanken voor de mogelijkheid die zij mij gegeven hebben om te studeren, maar nog veel meer voor jullie interesse in het onderzoek en het hebben van zulke trotse ouders.

Tot slot wil ik twee mensen bedanken welke mij de gelukkigste mens op aarde maken. Eline, met jou het leven delen is fantastisch! Je hebt mij geleerd om kwetsbaar te zijn, en ik heb gemerkt dat je er zoveel voor terug krijgt. Ook wil ik Sil bedanken voor het geluk dat jij in ons leven geeft. Ik kijk uit naar de vakanties aan het strand wanneer we samen gaan spelen tegen en met het water en dat je mag genieten van de liefde van mama en papa. 


\section{Summary}

\section{Biogeomorphology of coastal seas}

There is growing recognition of the importance of feedbacks between organisms and physical forces in landscape formation; a field labeled biogeomorphology. Biogeomorphological processes typically involve so-called ecosystem engineering species, which are organisms that modify the abiotic environment via their activity or physical structures and thereby create, modify and maintain habitats. Biogeomorphological processes are known to shape a broad range of landscapes. However, in the underwater landscape these interactions have received little attention, despite the high abundance of ecosystem engineering species in the bed of coastal seas.

This thesis aims at understanding the interaction between ecosystem engineering species, hydrodynamics and sediment dynamics in the formation of the underwater landscape. The most dynamic large-scale seabed patterns are tidal sand waves, with wavelengths of several hundreds of meters, heights of several meters and migration rates up to tens of meters per year. Within this dynamic landscape, ecosystem engineering species have a large impact on both the hydrodynamics and the sediment dynamics. In order to understand this interaction, we followed a model approach. Additionally, field observations and flume experiments are executed to obtain input parameters and validation data for the model studies.

\section{Modeling sand wave formation}

Up to now, the processes controlling the dynamics of sand waves are only partly understood and the formation of sand waves has only been studied in idealized models, in which geometry, boundary conditions and turbulence models are strongly schematized. Alternatively, in this thesis we present simulations of sand wave formation with a numerical shallow water model (Delft3D), in which process formulations are more sophisticated. We demonstrate that reproducing the basic sand wave formation mechanisms is possible, but requires careful treatment of vertical resolution and boundary conditions.

By using an advanced spatially and temporally variable turbulence model and modeling sediment transport both as bedload and suspended load transport, we were able to find critical conditions for sand wave formation. The simulations showed that sand waves were only formed when bedload transport was the dominant transport mode. As soon as suspended load transport became the dominant transport regime, sand waves were absent; a relation we also found in field observations. 


\section{Parameterization of ecosystem engineering species activity}

In order to include ecosystem engineering species in an idealized geomorphological model, we linked their activity to physical properties of the seabed. We focused on three ecosystem engineering species on the basis of (i) their abundance in sandy coastal seas, (ii) their strong modification of the environment, and (iii) their contrasting type of feeding and burrowing, and thereby contrasting influence on the sediment dynamics and hydrodynamics. The species selected are the tube-building worm Lanice conchilega, which reduces the near-bottom flow and consequently lowers the ripple height, the clam Tellina fabula which destabilizes the sediment and thereby decreases the critical bed shear stress for erosion and the sea urchin Echinocardium cordatum which redistributes the sediment, resulting in a coarser surface layer and a finer subsurface layer.

The tube-building worm Lanice conchilega was also parameterized in a numerical shallow water model, by adopting a module within the Delft3D model which explicitly accounts for the influence of cylindrical structures on the hydrodynamics (drag and turbulence). We validated this module in a flume experiment in which we measured the flow adaptation both within and outside a patch of worm mimicks with varying tube densities.

\section{Impact of ecosystem engineering species on sand wave characteristics}

Based on field observations for the Dutch part of the North Sea, we determined the contours of high densities of the three selected ecosystem engineering species. Model simulations showed that their activity can be sufficient to change the model behavior from presence to absence of sand waves and thereby significantly improving the model prediction on sand wave occurrence. Moreover, seasonal variation in both the migration rate and wavelength of sand waves is observed in the Marsdiep tidal inlet (The Netherlands). With help of our idealized biogeomorphological sand wave model, we demonstrated that variations in both physical (flow velocity and water temperature) and biological processes (density of tube-building worms) are capable of inducing the observed seasonal variation.

Next, we modeled the impact of tube-building worm patches on a flat seabed. On the small-scale (within the patch) mounds were formed within one year. These mounds affected the hydrodynamics and sediment dynamics on the landscape scale. Finally, we studied the self-organization in the underwater landscape in a two-way coupled biogeomorphological model. Within this model, the initial seabed consisted of small-amplitude randomized perturbations and the seasonal and patchy distribution of tube-building worms was prescribed by a simple tube-building worm growth model. At locations near the critical conditions of sand wave formation, mounds constructed by tube-building worms were able to suppress the formation of sand waves. However, at locations in the bedload regime, the landscape consisted of mounds on the flanks of tidal sand waves.

Given the similarities in model results for tube-building worms, we recommend to use both modeling approaches in a complementary way in future biogeomorphological research: idealized models for the long-term qualitative behavior and numerical shallow water models for short-term detailed predictions. 


\section{Samenvatting}

\section{Biogeomorfologie van ondiepe zeeën}

Het besef dat de interactie tussen organismen en fysische krachten bepalend is in de vorming van het landschap wordt steeds sterker; een onderzoeksveld dat biogeomorfologie wordt genoemd. In biogeomorfologische studies worden organismen bestudeerd die door hun aanwezigheid en activiteiten hun eigen habitat creeëren, aanpassen en in stand houden: het zijn ecosysteem ingenieurs. Echter, biogeomorfologische interacties in het onderwaterlandschap van ondiepe zeeën (zoals bijvoorbeeld de Noordzee) zijn nog niet bestudeerd, ondanks de grote aantallen ecosysteemingenieurs welke op de zeebodem voorkomen.

Deze dissertatie heeft tot doel om de interactie tussen ecosysteemingenieurs, hydrodynamiek en sedimentdynamiek (welke gezamenlijk het onderwaterlandschap vormen) te begrijpen. De meest dynamische grootschalige bodemvormen zijn zandgolven, met een golflengte van enkele honderden meters, een hoogte van enkele meters en een migratiesnelheid van enkele tientallen meters per jaar. In dit dynamische landschap leven ecosysteemingenieurs, welke de hydrodynamiek en sedimentdynamiek lokaal beïnvloeden en een seizoensvariatie in voorkomen laten zien. Om deze interactie te begrijpen, gebruiken we een modelbenadering. Daarnaast zijn veldobservaties en stroomgootexperimenten uitgevoerd om invoer parameters en validatiedata voor de modelstudies te verkrijgen.

\section{Modelleren van de vorming van zandgolven}

Toe nu toe zijn de processen welke de dynamiek van zandgolven controleren slechts gedeeltelijk begrepen en alleen bestudeerd in geïdealiseerde modellen. In deze modellen zijn de geometrie, randvoorwaarden en turbulentiemodellen sterk geschematiseerd. Als een alternatief presenteren wij in deze dissertatie simulaties van zandgolfformatie in een complex numeriek model (Delft3D). In dit model zijn geavanceerde procesformuleringen opgenomen. We laten zien dat voor het reproduceren van de vorming van zandgolven nauwkeurig gelet moet worden op de verticale resolutie en laterale randvoorwaarden.

Door gebruik te maken van een geavanceerd turbulentiemodel en het beschrijven van sedimenttransport als zowel bodemtransport en zwevend transport, vonden wij kritieke condities voor zandgolfformatie. De simulaties lieten zien dat zandgolven alleen gevormd worden wanneer bodemtransport het dominant transportmechanisme was. Zodra zwevend transport het dominante transportmechanisme was, werden zandgolven niet gevormd; een relatie welke we ook in veldobservaties vonden. 


\section{Parameteriseren van het gedrag van ecosysteemingenieurs}

De kwantitatieve beschrijving van de invloed van ecosysteemingenieurs op de fysische omgeving wordt een parameterisatie genoemd. Ten eerste stellen wij een parameterisatie op, welke gebruikt kan worden in geïdealiseerde modellen, voor drie verschillende ecosysteemingenieurs. Criteria voor selectie zijn (i) het veelvuldig voorkomen in zandige ondiepe zeeën (ii) de sterke beïnvloeding van de omgeving en (iii) de contrasterende manier van voeden en graven en daardoor de contrasterende invloed op de hydrodynamiek en sedimentdynamiek. De drie geselecteerde ecosysteemingenieurs zijn de kokerworm Lanice conchilega, welke de stroming bij de bodem vertraagt en daardoor de ribbelhoogte doet afnemen, de zeeschelp Tellina fabula welke het sediment destabiliseert en hiermee de kritieke bodemschuifspanning voor erosie verlaagt en de zee-egel Echinocardium cordatum welke het sediment herverdeelt, waardoor er een grovere laag ontstaat aan het oppervlakte van de zeebodem en een fijnere laag hieronder.

Daarnaast hebben we een parameterisatie voorgesteld, welke gebruikt kan worden in het Delft3D model voor de kokerworm Lanice conchilega. Binnen dit model is een module beschikbaar welke expliciet de invloed van cilinders op de stromingsweerstand en turbulentie beschrijft. In een stroomgootexperiment hebben wij deze module gevalideerd door de stromingsbeïnvloeding zowel buiten als binnen een cluster van drinkrietjes (een imitatie voor de kokerworm Lanice conchilega) te meten.

\section{Invloed van ecosysteemingenieurs op de vorming van zandgolven}

Met behulp van veldobservaties in het Nederlandse deel van de Noordzee, zijn de gebieden waar de drie geselecteerde ecosysteem ingenieurs in grote getale voorkomen bepaald. Simulaties met een geïdealiseerd model laten zien dat de activiteiten van ecosysteemingenieurs in deze gebieden sterk genoeg zijn om de vorming van zandgolven te beletten, en hierdoor de voorspelling van het voorkomen van zandgolven in het model significant te verbeteren. Daarnaast is in het veld een seizoensvariatie in zowel de migratiesnelheid als de golflengte van zandgolven waargenomen. Met behulp van ons geïdealiseerde biogeomorfologische model waren wij in staat om deze seizoensvariatie toe te schrijven aan zowel fysische (seizoensvariatie in stroomsnelheid en watertemperatuur) als biologische processen (seizoensvariatie in dichtheid kokerwormen).

Vervolgens modelleerden wij de invloed van een cluster kokerwormen op een vlakke zeebodem. Op de kleine schaal (in het cluster) werd binnen één jaar een heuveltje gevormd. Dit heuveltje beïnvloedde de hydrodynamiek en sedimentdynamiek in een gebied dat vele malen groter is dan het cluster zelf. Ten slotte bestudeerden wij de zelforganisatie van het onderwaterlandschap in een gekoppeld biogeomorfologisch model. Aan het begin van de simulatie bestond de bodem uit kleine onregelmatige verstoringen, en de ruimtelijke verdeling en seizoensvariatie in dichtheid kokerwormen werd voorgeschreven door een eenvoudig groeimodel. De uitkomsten van het model laten zien, dat in gebieden waar zowel bodemtransport als zwevend transport was, de heuveltjes van kokerwormen ervoor zorgden dat zandgolven niet gevormd werden. Echter, in gebieden waar bodemtransport het dominante transportmechanisme was, bestond het onderwaterlandschap uit heuveltjes gevormd door kokerwormen, gelegen op de flanken van zandgolven. 


\section{Chapter 1}

\section{Introduction}

\subsection{Biogeomorphology of coastal seas}

There is a growing recognition of the importance of feedbacks between organisms and physical forces in landscape formation, which is generally referred to as biogeomorphology (Murray et al., 2008; Reinhardt et al., 2010; Corenblit et al., 2011). Biogeomorphological processes typically involve so-called ecosystem engineering species, which are organisms that modify the abiotic environment via their activity or physical structures and thereby create, modify and maintain habitats (Jones et al., 1994). Biogeomorphological processes shape a broad range of landscapes, ranging from aeolian dunes (Baas and Nield, 2007) and alluvial floodplain rivers (Murray and Paola, 2003; Tal and Paola, 2007) to tidal marshes (D'Alpaos et al., 2007; Kirwan and Murray, 2007; Temmerman et al., 2007). In comparison, biogeomorphological interactions in the underwater landscape have received little attention. They are potentially equally important (Le Hir et al., 2009), but more difficult to observe and to model.

Rabaut (2009) gives qualitative field evidence for the biogeomorphological interactions in subtidal seabed dynamics. By using multibeam echosounder and side-scan sonar technology, both the migration of tidal sand waves and the spatial distribution of the tube-building worm Owenia fusiformis were mapped at several square kilometers of the Belgian North Sea. At locations where O. fusiformis was found in high densities, such as in the troughs of tidal sand waves, the seabed was stabilized and tidal sand waves showed no migration, whereas the tidal sand waves usually migrate 12 meters per year in that part of the Belgian North Sea. However, the study was only a correlative field study and no causal relationships were proved.

The subtidal seabed of coastal seas is highly important both from an economical and ecological perspective, as these areas provide a variety of services to human society and form the habitat for a broad variety of organisms. Many human activities such as maintaining navigation channels and constructing pipelines and telecommunication cables depend on a good understanding of the dynamic behaviour of the subtidal seabed (Németh et al., 2003). The conservation and management of the benthic biodiversity in the coastal zone also requires knowledge about spatial and temporal distribution of organisms and thus the sediment dynamics (Borja et al., 2000). Given the increasing demand for economic activities in future and the need to safeguard the sustainability of shallow shelf seas, studying the dynamic interaction between ecosystem engineering species and the subtidal seabed dynamics is desired. 

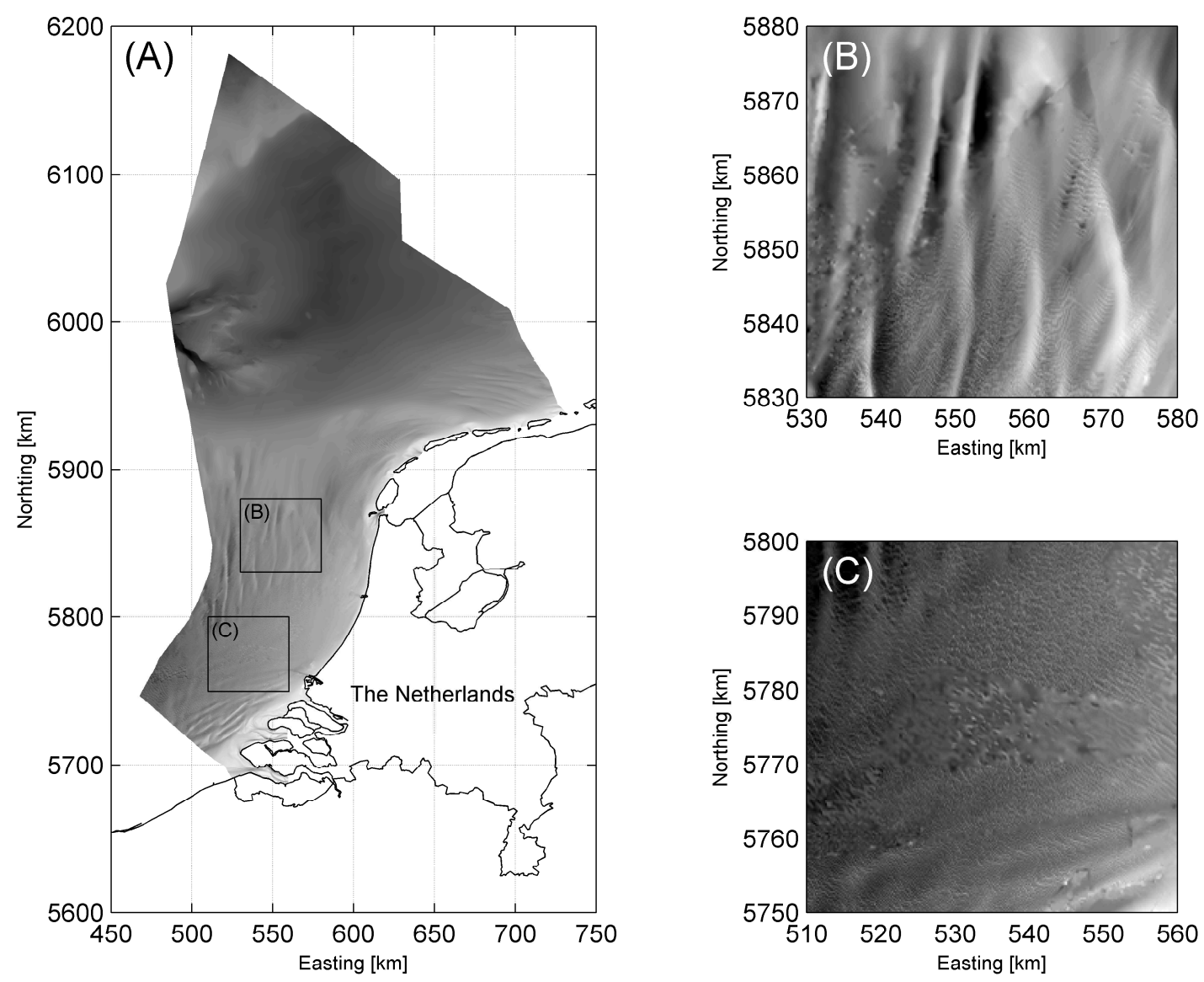

Figure 1.1: Subtidal seabed patterns in the Dutch part of the North Sea (A): tidal sandbanks with typical wavelengths of few kilometers (B) and tidal sand waves with typical wavelengths of hundreds of meters $(\mathrm{C})$. 
Table 1.1: Characteristic spatial and temporal scales of subtidal seabed patterns.

\begin{tabular}{lllll}
\hline & $\begin{array}{l}\text { Wavelength } \\
{[\mathrm{m}]}\end{array}$ & $\begin{array}{l}\text { Amplitude } \\
{[\mathrm{m}]}\end{array}$ & $\begin{array}{l}\text { Time scale } \\
{[\text { year }]}\end{array}$ & $\begin{array}{l}\text { Migration } \\
{\left[\mathrm{m} \mathrm{year}^{-1}\right]}\end{array}$ \\
\hline Mega-ripples & $10^{1}$ & $10^{0}$ & $10^{-1}$ & $10^{2}$ \\
Tidal sand waves & $10^{2}$ & $10^{0}$ & $10^{1}$ & $10^{1}$ \\
Tidal sandbanks & $10^{3}$ & $10^{1}$ & $10^{2}$ & $10^{0}$ \\
\hline
\end{tabular}

\subsection{Subtidal seabed patterns}

The bed of shallow shelf seas is neither flat nor static. Various rhythmic bed patterns are formed due to the complex interaction between the water motion and the sandy seabed. All these bed patterns have characteristic spatial and temporal scales (Table 1.1). On the largest spatial scale tidal sandbanks (Figure 1.1B) are observed with wavelengths (distance between two crests) of several kilometers and amplitudes of several tens of meters (Huntley et al., 1993). Tidal sandbanks hardly migrate and are assumed to evolve on a time scale of centuries (Dyer and Huntley, 1999). Tidal sand waves (Figure 1.1C) are medium scale bed patterns with typical wavelengths between 100 and 1000 meters, amplitudes in the order of $5 \mathrm{~m}$, migration rates up to tens of meters per year and evolving on a time scale of tens of years (Huntley et al., 1993). The orientation of tidal sand waves is almost perpendicular to the direction of the main tidal current (Terwindt, 1971; McCave, 1971). Tidal sand waves are observed in many tide-dominated sandy, shallow shelf seas such as the North Sea (Figure 1.1), Bisanseto Sea, Irish Sea, the shelf off Spain and Argentina and in many straits and tidal inlets around the world (Van Santen et al., 2011). On a much smaller spatial scale, mega-ripples are observed with wavelengths of a couple of meters and a height up to a meter. These mega-ripples are flow-transverse bed patterns, migrate with a rate of about $0.5 \mathrm{~m}$ per day and can be superimposed on sand waves (Tobias, 1989; Ashley, 1990; Wever and Stender, 2000).

Subtidal seabed patterns are explained as morphodynamic instabilities of a flat seabed subject to tidal flow and sediment transport (Richards, 1980; Huthnance, 1982; Hulscher, 1996). Therefore, stability analyses are applied to study the formation of tidal sand banks, tidal sand waves and mega-ripples (for an overview see Dodd et al., 2007; Besio et al., 2008). However, the study of the formation of subtidal seabed patterns is limited, because none of the models is able to reproduce the formation of fully-developed subtidal seabed patterns by random perturbations, as is the case in nature. Therefore we can conclude that the physical mechanisms in the formation of subtidal seabed patterns are not completely understood.

\subsection{Ecosystem engineering species}

The bed of shallow shelf seas is known as a valuable ecosystem (Reise et al., 2010). Different communities can be found on the sandy seabed (Heip et al., 1992; Künitzer et al., 1992; Rabaut et al., 2007) showing a strong spatial and temporal variation (Van Hoey et al., 2004; Baptist et al., 2006). Most of the species live in the top centimeters of the seabed. Many are known as ecosystem engineering species (Jones et al., 1994), as they change the structure of the seafloor environment in ways not done by physical processes alone (Rhoads, 1974; Nowell et al., 1981). Ecosystem engineering 


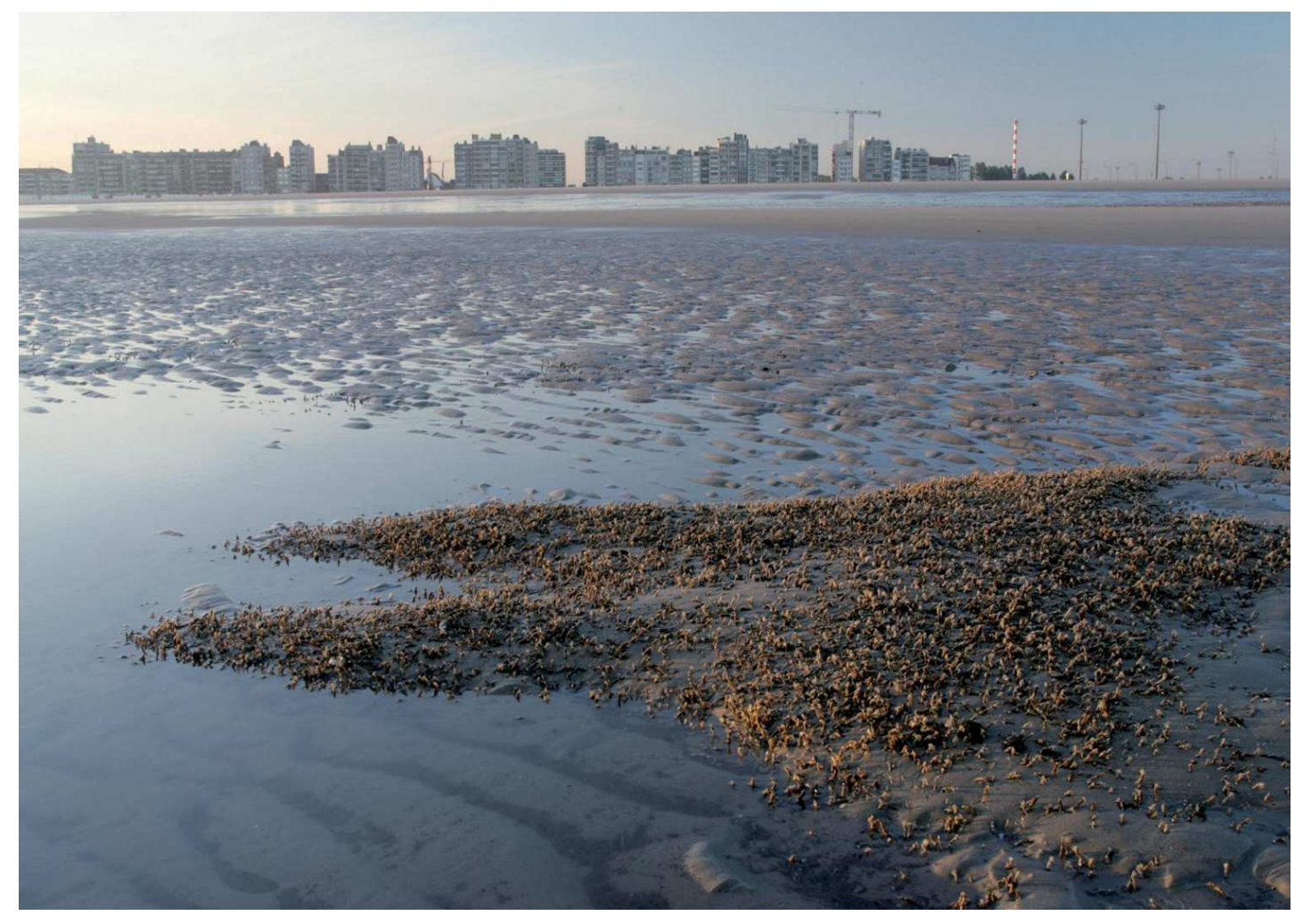

Figure 1.2: The ecosystem engineering species Lanice conchilega occurs in dense patches and stabilizes the sediment. Patches of these tube-building worms are observed at both the intertidal and subtidal seabed. Location of photo: Zeebrugge (Belgium). Photo courtesy: Prof. Dr. Steven Degraer - Ghent University.

species rework the substrate (bioturbation) for feeding, building burrows, locomotion and ventilation, or provide structures by themselves that are used by other species, e.g. tube-building worms (Figure 1.2). The interaction between ecosystem engineering species and hydrodynamics and sediment dynamics has been well studied and clearly shown for the intertidal environment in field studies (e.g. Austen et al., 1999; De Deckere et al., 2001; Andersen et al., 2002), flume experiments (e.g. Widdows et al., 1998; Friedrichs et al., 2000; Van Duren et al., 2006) and modeling studies (e.g. Paarlberg et al., 2005; Lumborg et al., 2006; Borsje et al., 2008a). All these studies conclude that ecosystem engineering species are able to influence both the sediment dynamics and hydrodynamics by several orders of magnitude and can act on a large spatial (several square kilometers) and temporal (seasonal and inter-annual) scale. However, the impact of ecosystem engineering species on the hydrodynamics and sediment dynamics and hence the morphodynamics of the subtidal seabed of coastal seas remains unclear. 


\subsection{Problem formulation}

Until now, the morphodynamic processes in coastal seas are only partly understood and the activity by ecosystem engineering species is not accounted for. Since ecosystem engineering species have been shown to impact the hydrodynamics and sediment dynamics to a great extent, the reliability of the current morphodynamics models is questionable, especially in coastal seas with high abundances of ecosystem engineering species.

The most important biogeomorphological interactions to understand are the cases showing a mutual interaction between physical and ecological processes (Renschler et al., 2007). These mutual bio-physical interactions are defined by Reinhardt et al. (2010) as "feedbacks in which the physical environment regulates the numbers and types of organisms that can coexist in a community and shape the selective environment that drives evolution while, at the same time, the organisms themselves modify the environment in a way that enhances their own persistence". Given the large migration rate and the short time scale of formation of mega-ripples (Table 1.1), ecosystem engineering species will only partly influence the sediment dynamics and hydrodynamics. On the other hand, regarding tidal sandbanks, ecological processes are assumed to hardly influence the formation processes which occur on a relatively large time scale. However, the physical environment will largely regulate the number and types of organisms (Baptist et al., 2006). In contrast, in tidal sand wave formation, both feedback mechanisms are likely to be present. This is due to the comparable spatial and temporal scale: ecosystem engineering species influence the formation of tidal sand waves and the physical environment controls the types, numbers and distribution of ecosystem engineering species. Therefore, in this thesis we will restrict our attention to the biogeomorphological interactions in tidal sand wave formation.

\subsection{Research approaches: field observations, flume exper- iments and model studies}

Three different research approaches are available to unravel the dynamic interactions among ecosystem engineering species, hydrodynamics and sediment dynamics: field observations, flume experiments and model studies. Given the spatial and temporal scales involved in the biogeomorphodynamic interactions of tidal sand waves, flume experiments and field observations will not provide a complete understanding of the dynamic interaction between morphodynamics and ecosystem engineering species. Model studies provide a more generic knowledge and are extrapolated more easily to other locations and circumstances. However, field observations and flume experiments are indispensable to obtain input parameters and validation data for the model studies.

In order to model the three different time scales in biogeomorphological interactions, we introduce the biogeomorphological loop (Figure 1.3), which is an extension of the classical morphological loop (e.g. see Roos and Hulscher, 2003). The separation in three time scales is essential, as the interaction among hydrodynamics, sediment transport and ecosystem engineering activity occurs within a tidal cycle $\left(\mathrm{T}_{\text {hydro }}\right.$ is in the order of half a day) and the bed evolution acts on a much longer time $\left(\mathrm{T}_{m o r}\right.$ is in the order of tens of years in case of tidal sand waves). The time scale $\mathrm{T}_{\text {bio }}$ on which the ecosystem engineering activity varies is seasonal. However, due to morphological changes, the ecosystem engineering activity might also change on a longer time scale (inter-annual). 


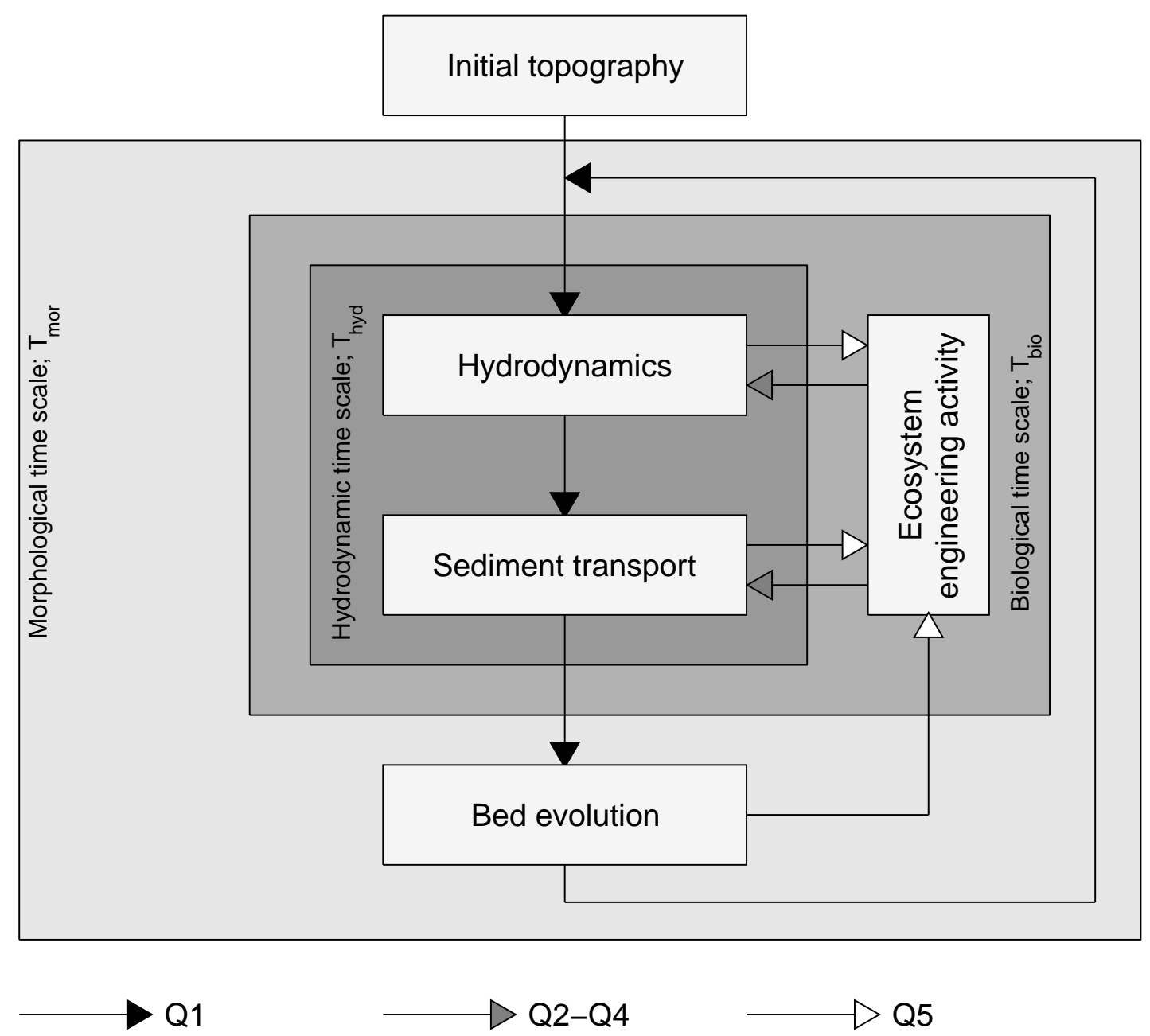

Figure 1.3: The biogeomorphological loop describes the interactions among hydrodynamics, sediment transport, ecosystem engineering activity and bed evolution at three different time scales. Starting from an initial topography, the hydrodynamics initiate the transport of sediment and hence the bed evolution. Both the hydrodynamics and sediment transport are influenced by ecosystem engineering activity. At the same time, the ecosystem engineering activity is influenced by the hydrodynamics, sediment transport and bed evolution. Different arrow colors indicate different research questions (Q1-Q5) which will be discussed in Section 1.7. 


\subsection{Understanding tidal sand wave formation: idealized models vs. numerical shallow water models}

The first model used to explain tidal sand wave formation was formulated by Hulscher (1996). She showed that the interaction of the oscillatory tidal current with a bottom perturbation gives rise to a tide-averaged residual circulation directed from the trough towards the crest of a tidal sand wave. This residual circulation induces a net sediment flux towards the crest of the tidal sand wave, which leads to tidal sand wave growth if the sediment transport overcomes the opposing effect of gravity. The model by Hulscher (1996) was extended in several studies, focusing on the hydrodynamic solution method (Gerkema, 2000, Besio et al., 2003), the inclusion of residual currents and/or overtides (Németh et al., 2002; Besio et al., 2004), turbulence formulation (Komarova and Hulscher, 2000), suspended sediment transport (Blondeaux and Vittori, 2002ab) and grain size variations (Van Oyen and Blondeaux, 2009). The main limitation is that all models listed above are only valid for the initial stage of formation of tidal sand waves (small-amplitude tidal sand waves; the linear regime). When amplitudes increase, non-linear effects become important but these effects cannot be captured with a linear approach. The model validity is thus limited to small-amplitude tidal sand waves. Therefore comparison between wavelengths found in the models with wavelengths found in the field is questionable, despite the reasonable qualitative agreement (Cherlet et al., 2004; Van Santen et al., 2009). Németh et al. (2007) and Van den Berg et al. (2009) proposed a non-linear model in which the tidal sand wave behavior is modeled from its initial stage until an equilibrium shape. In both models, the simulations start with a small-amplitude sinusoidal bed perturbation, with a wavelength based on the fastest growing mode given by a linear stability analysis. The domain length is restricted to the wavelength of a single tidal sand wave, since model simulations on a larger domain show a tendency that the tidal sand wave field evolves towards one large bedform with a wavelength equal to the domain length (Sterlini et al., 2009).

All models listed above are so-called idealized models, which assume simplified physical process formulations. Alternatively, in this thesis we explore the possibility to study tidal sand wave formation in a numerical shallow water model (Delft3D). The advantage of such a model approach is that many physical processes can be included in a sophisticated way (e.g. wind- and wave-driven currents, density gradients, sediment transport, advanced turbulence models). Detailed process formulations are desired for two reasons. First, ecosystem engineering species are known to influence the hydrodynamics and sediment dynamics in a complex way (e.g. Eckman et al., 1981; Friedrichs et al., 2000). Secondly, the simplified physical process formulations used in idealized models result in unrealistic behavior. Moreover, in a numerical shallow water model we can incorporate the heterogeneous distribution of ecosystem engineering species in space and time, thus allowing us to model the patchily distributed ecosystem engineering species. However, given the high spatial and temporal resolution required to model tidal sand wave formation, a numerical shallow water model requires large computational effort. Therefore, using both modeling approaches in a complementary way is essential: numerical shallow water models for the short-term detailed predictions and idealized models for the long-term qualitative behavior. 


\subsection{Objectives and research questions}

The objectives of the thesis are as follows: (1) to model tidal sand wave formation in a numerical shallow water model, (2) to quantify the interactions among ecosystem engineering activity, sediment dynamics and hydrodynamics, (3) to implement and validate biogeomorphological models, and (4) to find the dominant processes and timescales in biogeomorphological interactions for tidal sand waves. The following five research questions are formulated to achieve the objectives:

Q1. Can tidal sand wave formation be reproduced in a numerical shallow water model (Delft3D), and how do the results of the model compare to the results of idealized sand wave models?

Q2. What is the potential impact of biogeomorphological influences on tidal sand wave dynamics?

Q3. How can the most important ecosystem engineering species be parameterized in order to be incorporated in existing geomorphological models?

Q4. Can the biogeomorphological models (Q3) be applied to different test cases, and how do the results of the models compare to field observations?

Q5. By extending a biogeomorphological tidal sand wave model (Q3) with the feedback from the bed evolution, hydrodynamics and sediment transport to ecosystem engineering activity, what are the dominant processes and time scales in this two-way coupled biogeomorphodynamic model?

\subsection{Outline of the thesis}

The thesis consists of nine chapters, in which the five research questions are answered (Figure 1.4). For each chapter the use of field data (black rectangle), models (gray rectangle) or flume experiments (white rectangle) is indicated. Whether the field data, models or flume experiments are taken from literature or presented as new in this thesis is indicated with a triangle and a circle respectively. In all chapters new (biogeo)morphological models are presented. From Chapter 4 onward, distinction is made between one-way and two-way coupled models. In a one-way coupled biogeomorphological model only the impact from ecosystem engineering activity on the physical processes is accounted for (gray arrows in Figure 1.3). In a two-way coupled biogeomorphological model, also the impact of physical processes on ecosystem engineering species occurrence is accounted for (both white and gray arrows in Figure 1.3). In Chapter 6 new flume experiments are presented and in Chapter 3, 4 and 6 new field data are used to set-up the different (biogeo)morphological models and/or to validate the outcome of the (biogeo)morphological models. Within the thesis, distinction is made between idealized models and numerical shallow water models to study tidal sand wave formation, as discussed in Section 1.6 (two pillars in Figure 1.4).

The first part of the thesis is dedicated to the physical mechanisms in tidal sand wave formation. In two chapters, the role of turbulence formulation (Chapter 2) and suspended load transport (Chapter 3) on tidal sand wave formation and occurrence is studied in the numerical shallow water model Delft3D. Next, a literature review is presented on the state-of-the-art on biogeomorphological influences on tidal sand wave 
dynamics. Moreover, a simple representation of the activity by ecosystem engineering species is included in an idealized model (Besio et al., 2008), to obtain a first insight in the potential impact of ecological activity on tidal sand wave occurrence and tidal sand wave length (Chapter 4). In order to link the activity by the ecosystem engineering species to the formation of tidal sand waves, parameterizations are proposed. The parameterization used in the idealized model is a dependency of the critical bed shear stress, roughness height and grain size distribution on the abundance of ecosystem engineering species (Chapter 5). For the numerical shallow water model, the hydrodynamics are extended to explicitly account for the flow through and over the tubes of a tube-building worm field and validated with partly new flume experiments (Chapter 6). The one-way coupled idealized tidal sand wave model is applied in a test case. The impact of ecosystem engineering species on the migration rate of tidal sand waves in the Marsdiep, a tidal inlet in the Netherlands, is studied (Chapter 7). Subsequently, the two-way coupling between ecosystem engineering species and morphodynamics of a tidal sand wave field is studied (Chapter 8). Finally, the results of this thesis are discussed and answers to the research questions are given (Chapter 9). 


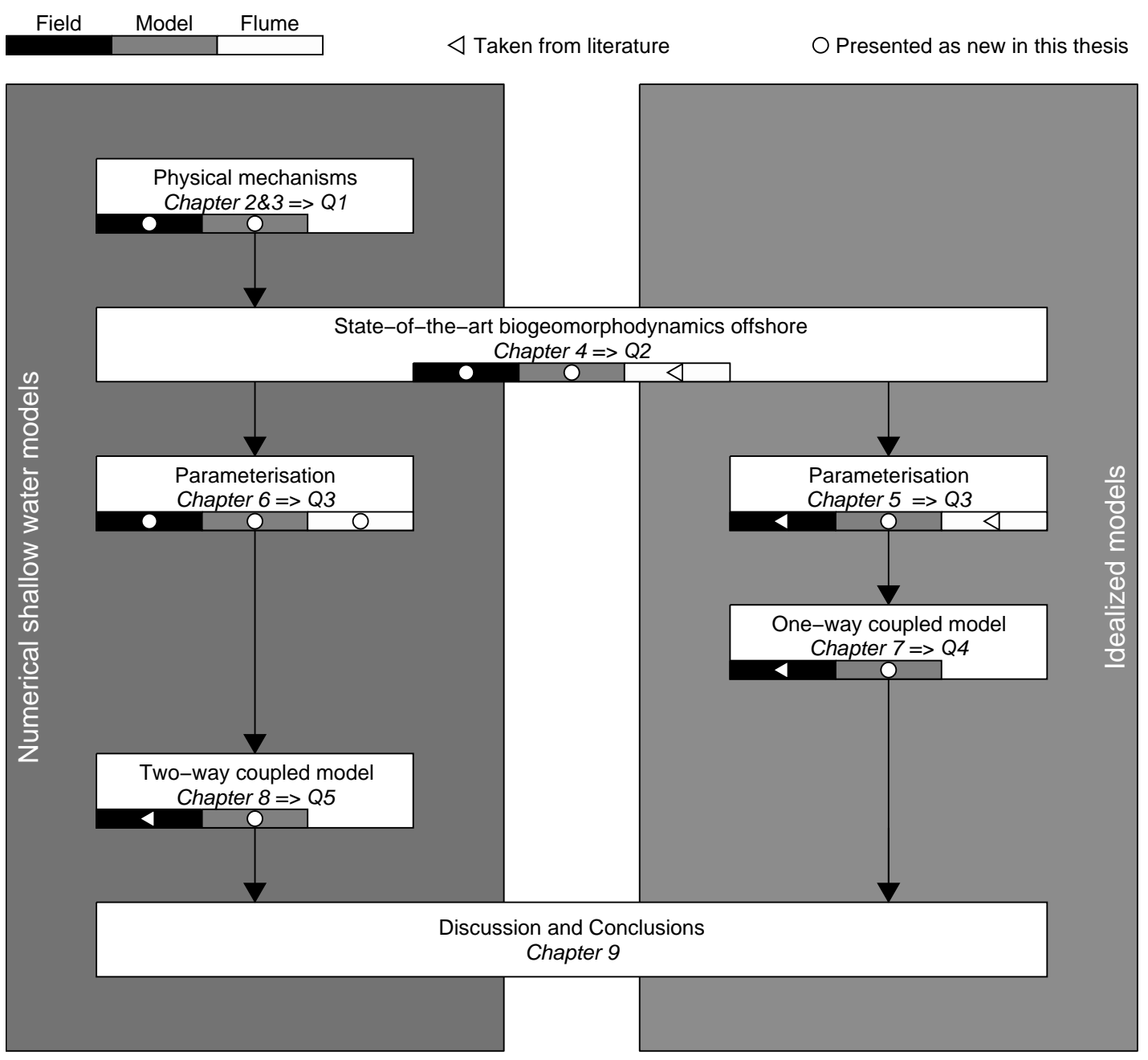

Figure 1.4: Outline of the thesis. The five research questions (Q1-Q5) are discussed in 9 chapters. Whether the field data (black rectangle), models (gray rectangle) or flume experiments (white rectangle) are taken from literature or presented as new in this thesis is indicated with a triangle and circle respectively. Distinction is made between numerical shallow water models (left pillar) and idealized models (right pillar). 


\title{
Chapter 2
}

\section{Modeling tidal sand wave formation in a numerical shallow water model}

This chapter is based on the paper:

B.W. Borsje, P.C. Roos, W.M. Kranenburg, S.J.M.H. Hulscher. Modeling tidal sand wave formation in a numerical shallow water model: the role of turbulence formulation, under review.

\begin{abstract}
Tidal sand waves are prominent dynamic bottom features in shallow sandy seas such as the Southern North Sea. Up to now, the processes controlling the dynamics of these bedforms have only been studied in idealized models, in which geometry, boundary conditions and turbulence models are schematized. Alternatively, in this chapter we present simulations of sand wave formation and migration with a numerical shallow water model (Delft3D), in which we restrict ourselves to bedload transport and study the initial formation stage only. First, it is shown that reproduction of the basic sand wave formation mechanisms in a numerical shallow water model requires careful treatment of model geometry, initial profile, vertical resolution and lateral boundary conditions. Secondly, an intercomparison between the Delft3D model and an idealized sand wave model is performed. Next, we compare the results for two of the built-in turbulence models: constant vertical eddy viscosity model (commonly used in idealized models) and a more advanced spatially and temporally variable vertical eddy viscosity model ( $k-\epsilon$ turbulence model). Finally, the model results are compared with field data on sand wave length. The $k-\epsilon$ turbulence model shows good agreement with the field data, whereas the constant vertical eddy viscosity model overestimates the wavelength of the sand waves considerably.
\end{abstract}




\section{$2.1 \quad$ Introduction}

Large parts of the sandy seabed of shallow seas, such as the North Sea, are covered with rhythmic bed patterns (Huntley et al., 1993). These bed patterns are the result of the complex interaction among hydrodynamics, sediment transport and morphology. The most dynamic large scale bed patterns are tidal sand waves, which regenerate in several years time (e.g. after dredging, see Knaapen and Hulscher, 2002), may grow up to $25 \%$ of the water depth (McCave, 1971), have wavelengths (distance between two successive crests) in the order of hundreds of meters (Van Dijk and Kleinhans, 2005) and migrate at a speed up to tens of meters per year (Terwindt, 1971; Dorst et al., 2009). In the Southern North Sea, sand waves are observed in water depths in the order of $25 \mathrm{~m}$, depth-averaged tidal flow velocity amplitudes around $0.65 \mathrm{~m} \mathrm{~s}^{-1}$ and median grain sizes of $0.35 \mathrm{~mm}$ (Borsje et al., 2009a; Chapter 4).

Given their dynamic behavior, sand waves may pose a hazard to offshore activities, by reducing the water depth of navigation channels, exposing pipelines and telecommunication cables and scouring offshore platforms or wind turbines (Németh et al., 2003). Consequently, insight in the processes controlling the variation in tidal sand wave characteristics is essential for cost-effective management practices. Hulscher (1996) showed that sand wave formation can be explained as an inherent instability of the sandy seabed subject to tidal motion. The interaction of the oscillatory tidal current with a bottom perturbation gives rise to a tide-averaged residual circulation directed from the trough towards the crest of the sand wave. This residual circulation induces a net sediment flux towards the crest of sand waves, which leads to sand wave growth if the sediment transport overcomes the opposing effect of gravity. It is this competition between destabilizing and stabilizing sediment fluxes that defines a preferred wavelength, termed the fastest growing mode (FGM). The model by Hulscher (1996) describes the hydrodynamics by using the three-dimensional shallow water equations. The turbulent stresses are accounted for by combining a constant vertical eddy viscosity with a partial slip condition at the bed. Sediment transport is only modeled as bedload transport. Despite the strongly schematized representation of the physical processes, the occurrence of sand waves in the Southern North Sea was predicted reasonably (Hulscher and van den Brink, 2001). Later, Komarova and Hulscher (2000) extended the model of Hulscher (1996) by introducing a time dependency in the vertical eddy viscosity while keeping a partial slip condition at the bed. Moreover, Gerkema (2000) and Besio et al. (2003) extended the model of Hulscher (1996) by focusing on the hydrodynamic solution method. To explain sand wave migration, Németh et al. (2002) and Besio et al. (2004) introduced a residual current and tidal asymmetry respectively, while keeping the simplified turbulence model. Blondeaux and Vittori (2005ab) and Besio et al. (2006) extended the model proposed by Hulscher (1996) by introducing a depth dependent eddy viscosity in combination with a no-slip condition at the bed. Moreover, both bedload transport and suspended load transport are included in the model. The model was able to reproduce the sand wave length at different locations on the Belgium Continental Shelf fairly well (Cherlet et al., 2007).

All the models discussed above are based on a linear stability analysis. In a linear stability analysis the growth rate of different infinitesimal perturbations is determined and the perturbation with the fastest growing mode is assumed to prevail. The model validity is thus limited to small-amplitude sand waves. Therefore, Németh et al. (2007) and Van den Berg et al. (2012) proposed a non-linear model in which the sand wave 
behavior is modeled from its initial stage until an equilibrium shape. In both models a constant vertical eddy viscosity in combination with a partial slip condition at the bed is adopted. The model of Van den Berg et al. (2012) was able to reproduce the final sand wave length, height and shape at different locations in the Golden Gate region fairly well (Sterlini et al., 2009). However, the migration rates were largely overestimated by the model.

In this chapter we explore the possibility to study sand wave formation in a numerical shallow water model. The advantage of such a model approach is that many physical processes can be included in a sophisticated way (e.g. wind- and wave-driven currents, density gradients, sediment transport, advanced turbulence models). However, given the high spatial and temporal resolution required to model tidal sand wave formation, these models require large computational effort. Also, treatment of lateral boundary conditions requires care. So far, the only study in which a numerical shallow model was used to investigate morphodynamic behavior of a sand wave was done by Tonnon et al. (2007). However, their study focused on one artificial sand wave, which makes it difficult to understand the processes controlling the formation of natural sand wave patterns.

In this study, we use the numerical shallow water model Delft3D with a schematized geometry and focus on small-amplitude sand waves. Consequently, in this chapter we only study the initial stage of sand wave formation. In the Delft3D model different turbulence closure models are built-in. The constant vertical eddy viscosity model is used to make an intercomparison between the Delft3D model and an idealized sand wave model (Van den Berg et al., 2012)). The $k-\epsilon$ turbulence model allows the eddy viscosity to vary both in time and space and is used to determine the role of turbulence formulation on sand wave formation. As pointed out by Besio et al. (2006), the main improvement in the simplified description of sand wave formation in idealized models would be a better turbulence model capable of describing the time variation of turbulence.

The aim of this chapter is twofold. First, we aim to reproduce the initial stage of sand wave formation with a numerical shallow water model. Secondly, we aim to compare two of the built-in turbulence models: constant vertical eddy viscosity and $k-\epsilon$ and the effect on sand wave formation and migration. We compare the model results with field measurements on the wavelength of sand waves in the Southern North Sea.

The outline of this chapter is as follows. First, the Delft3D model set-up is given, including model equations, boundary conditions and geometry (Section 2.2). Next, model results are presented with specific attention for the residual circulation and the growth rates. Moreover, the residual circulation obtained with the Delft3D is compared with the residual circulation obtained with the idealized sand wave model of Van den Berg et al. (2012). Subsequently, the impact of the $k-\epsilon$ turbulence model on the preferred sand wave length and migration is compared with the constant vertical eddy viscosity model (Section 2.3). The model results are compared with sand wave lengths as observed in the Southern North Sea (Section 2.4). Section 2.5 discusses the main findings of this chapter, focusing on the similarities and differences between the model results of the Delft3D model and idealized sand wave models. Finally, the conclusions are given (Section 2.6). 


\subsection{Model description}

\subsubsection{Hydrodynamics}

The formation of sand waves is modeled using the numerical shallow water model Delft3D-FLOW (Lesser et al., 2004). The system of equations consists of horizontal momentum equations, a continuity equation, a turbulence closure model, a sediment transport equation and a sediment continuity equation. The vertical momentum equation is reduced to the hydrostatic pressure relation as vertical accelerations are assumed to be small compared to gravitational acceleration. The model equations are solved by applying sigma layering in the vertical (Deltares, 2012). In this study, the model is run in the 2DV mode, i.e. considering flow and variation in $x$ and $z$ direction only, while assuming zero flow and uniformity in $y$ direction and ignoring Coriolis effects. At the length scales of sand waves, Coriolis effects have been shown to have a negligible effect (Hulscher, 1996).

In terms of the $\sigma$-coordinates, the $2 \mathrm{DV}$ hydrostatic shallow water equations are described by:

$$
\begin{gathered}
\frac{\partial u}{\partial t}+u \frac{\partial u}{\partial x}+\frac{\omega}{(H+\zeta)} \frac{\partial u}{\partial \sigma}=-\frac{1}{\rho_{w}} P_{u}+F_{u}+\frac{1}{(H+\zeta)^{2}} \frac{\partial}{\partial \sigma}\left(\nu \frac{\partial u}{\partial \sigma}\right), \\
\frac{\partial \omega}{\partial \sigma}=-\frac{\partial \zeta}{\partial t}-\frac{\partial[(H+\zeta) u])}{\partial x} .
\end{gathered}
$$

Here $u$ is the horizontal velocity, $\omega$ is vertical velocity relative to the moving vertical $\sigma$-plane, $\rho_{w}$ is the water density, $H$ is water depth below reference datum, $\zeta$ is the free surface elevation, $P_{u}$ is the pressure gradient, $F_{u}$ is the horizontal Reynolds stress and $\nu$ is the vertical eddy viscosity.

Two different turbulence models are used in the simulations presented in this chapter. The first turbulence model assumes a constant value for the vertical eddy viscosity both in time and space (Equation 2.3: Fredsøe and Deigaard, 1992). The second turbulence model is the more advanced $k-\epsilon$ turbulence closure model in which both the turbulent energy $k$ and the dissipation $\epsilon$ are computed (Equation 2.4: Rodi, 1984). The resulting vertical eddy viscosity $\nu$ is variable both in time and space (for details on the $k-\epsilon$ turbulence model formulations see Burchard et al. (2008)):

$$
\begin{gathered}
\nu=\frac{\kappa U H_{0} \sqrt{g}}{6 C}, \\
\nu=c_{\mu} \frac{k^{2}}{\epsilon}
\end{gathered}
$$

in which $\kappa$ is the von kármán constant $(0.41), U$ is the amplitude of the depthaveraged flow velocity, $H_{0}$ is the mean water depth, $g$ is the gravitational acceleration, $C$ is the Chézy roughness coefficient and $c_{\mu}$ is a constant with a recommended value of 0.09 (Rodi, 1984).

At the bed $(\sigma=-1)$, a quadratic friction law is applied and the vertical velocity $\omega$ is set to zero:

$$
\tau_{b} \equiv \rho_{w} \frac{\nu}{(H+\zeta)} \frac{\partial u}{\partial \sigma}=\rho_{w} u_{*}\left|u_{*}\right|, \omega=0
$$


in which $\tau_{b}$ is the bed shear stress and $u_{*}$ is the shear velocity, that relates the velocity gradient at the bed to the velocity $u$ in the lowest computational grid point by assuming a logarithmic velocity profile.

At the free surface $(\sigma=0)$, a no-stress condition is applied and the vertical velocity $\omega$ is set to zero:

$$
\rho_{w} \frac{\nu}{(H+\zeta)} \frac{\partial u}{\partial \sigma}=0, \omega=0
$$

\subsubsection{Sediment transport and bed evolution}

The bedload transport, $S_{b}$ is calculated by (Van Rijn et al., 2004):

$$
S_{b}=0.006 \alpha_{s} \rho_{s} \omega_{s} d M^{0.5} M_{e}^{0.7}
$$

where $\alpha_{s}$ is a correction parameter for the slope effects (see below), $\rho_{s}$ is the specific density of the sediment, $w_{s}$ is the settling velocity of the sediment and $d$ the sediment grain size. $M$ and $M_{e}$, the sediment mobility number and excess sediment mobility number, respectively, are given by:

$$
\begin{gathered}
M=\frac{u_{r}^{2}}{\left(\rho_{s} / \rho_{w}-1\right) g d}, \\
M_{e}=\frac{\left(u_{r}-u_{c r}\right)^{2}}{\left(\rho_{s} / \rho_{w}-1\right) g d},
\end{gathered}
$$

where $u_{r}$ is the magnitude of the equivalent depth-averaged velocity computed from the velocity in the bottom computational layer assuming a logarithmic velocity profile, $u_{c r}$ is the critical depth-averaged velocity for the initiation of motion of sediment based on the Shields curve. If $u_{r}<u_{c r}$ the bedload transport is set to zero.

Bedload transport is affected by bed level gradients, which makes sediment transported downhill more easily than uphill. Following Bagnold (1956), the correction parameter $\alpha_{s}$ for the slope effect for small-amplitude sand waves is given by:

$$
\alpha_{s}=\lambda_{s}
$$

where $\lambda_{s}$ is the slope parameter which is usually taken inversely proportional to the tangent of the angle of repose of sand (Sekine and Parker, 1992) leading to $\lambda_{s}=2.5$.

Finally, the bed evolution is governed by the sediment continuity equation (Exner equation), which reads:

$$
\left(1-\epsilon_{p}\right) \frac{\partial z_{b}}{\partial t}+\frac{\partial S_{b}}{\partial x}=0
$$

in which $z_{b}$ is the upwards positively defined bed level and $\epsilon_{p}=0.4$ is the bed porosity. Equation 2.11 simply states that convergence (or divergence) of the bedload transport rate must be accompanied by a rise (or fall) of the bed profile. 


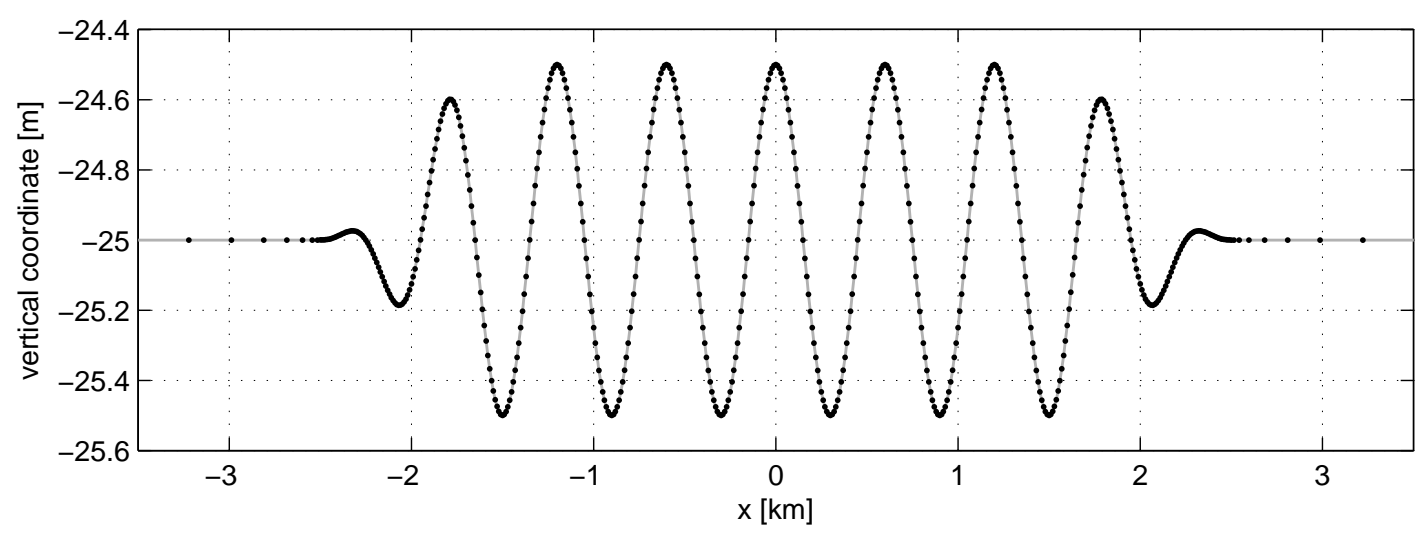

Figure 2.1: Initial bed level for a sand wave field with a wavelength $L=600 \mathrm{~m}$. The crest of the central sand wave is located at $x=0$. The total model domain is $50 \mathrm{~km}$. Horizontal grid points are indicated with dots.

\subsubsection{Model set-up}

In the horizontal orientation, the model domain is 50 kilometers, with a variable horizontal resolution. In the centre of the model domain the grid size is 10 meters, increasing to a value of $1500 \mathrm{~m}$ at the lateral boundaries. In the vertical orientation, the model grid is composed of 20 layers, with small vertical resolution near the bed and increasing towards the water surface. At the lateral boundaries, a so-called Riemann boundary condition is imposed (Verboom and Slob, 1984). For this type of boundary condition, outgoing waves are allowed to cross the open boundary without being reflected back into the computational domain, as happens for other type of boundary conditions. The semi-diurnal depth-averaged velocity amplitude $U_{M 2}$ at these lateral boundaries is set at $U_{M 2}=0.65 \mathrm{~m} \mathrm{~s}^{-1}$ and the tidal frequency $\sigma_{M 2}=1.45 \cdot 10^{-4} \mathrm{~s}^{-1}$. The depth-averaged velocity amplitude is imposed with a logarithmic vertical profile at the lateral boundary. The initial bed level perturbation $z_{b}$ is prescribed by a multiplication of a sinusoidal sand wave pattern of a given wavelength $L$ and amplitude $A$ with an envelope function, ensuring a gradual transition from the flat bed towards the sand wave field in the centre of the domain (Figure 2.1). Consequently, a coarser grid can be used near the boundaries. The mean water depth $H_{0}=25 \mathrm{~m}$ and the sediment grain size $d=0.35 \mathrm{~mm}$. The setting for flow velocity amplitude, mean water depth and grain size resemble a typical North Sea situation for sand wave occurrence (Borsje et al., 2009a; Chapter 4). The Chézy roughness coefficient $C=65 \mathrm{~m}^{1 / 2} \mathrm{~s}^{-1}$, following Tonnon et al. (2007). The initial amplitude of the sand wave $A_{0}=0.5 \mathrm{~m}$. Smaller initial amplitudes show the same quantitative behavior, but require more vertical layers to reproduce the near-bed flow characteristics and are consequently more time consuming. The model is run for two tidal cycles. The first tidal cycle is used for spin-up and no bed level changes are computed during this period. The second tidal cycle is used for determining the bed evolution. All default parameter settings are listed in Table 2.1. The sets of tidal conditions will be referred to in Section 2.3. 
Table 2.1: Overview of the values and dimensions of the model parameters.

\begin{tabular}{llllll}
\hline Description & Symbol & Value(s) & & & Dimension \\
\hline Tidal frequency of $\mathrm{M}_{2}$-tide & $\sigma_{M 2}$ & $1.45 \cdot 10^{-4}$ & & & $\mathrm{~s}^{-1}$ \\
Mean water depth & $H_{0}$ & 25 & & & $\mathrm{~m}$ \\
Sediment grain size & $d$ & 0.35 & & & $\mathrm{~mm}$ \\
Sand wave length & $L$ & {$[160-4500]$} & & & $\mathrm{m}$ \\
\hline Tidal conditions & & $\mathrm{I}$ & $\mathrm{II}$ & $\mathrm{III}$ & \\
\hline Amplitude of horizontal & & & & & \\
$\mathrm{M}_{2}$-tidal velocity & $\mathrm{U}_{M 2}$ & 0.65 & 0.65 & 0.65 & $\mathrm{~m} \mathrm{~s}^{-1}$ \\
Residual current $\mathrm{M}_{0}$ & $\mathrm{U}_{M 0}$ & 0 & 0.05 & 0 & $\mathrm{~m} \mathrm{~s}^{-1}$ \\
Amplitude of horizontal & & & & & \\
M & & & & & \\
Phase lidal velocity between $\mathrm{M}_{2}$ and $\mathrm{M}_{4}$ & $\phi$ & - & - & 120 & $\circ$ \\
\hline
\end{tabular}

\subsection{Results}

\subsubsection{Hydrodynamics}

First, we study the effect of the different turbulence models on the eddy viscosity profile and flow velocity profile for a flat bed. The flat bed serves as the basic state in a linear stability analysis (Dodd et al., 2003). The eddy viscosity profile for the constant vertical eddy viscosity model shows a higher tide-averaged eddy viscosity $\nu_{M 0}$, compared to the $k-\epsilon$ turbulence model (Figure 2.2A). In addition, the $k-\epsilon$ turbulence model also shows a time dependency in $\nu$. The most dominant component shows an amplitude of $\nu_{M 4}=0.025 \mathrm{~m}^{2} \mathrm{~s}^{-1}$ (Figure 2.2B) and a phase $\theta_{M 4}$ of around $120^{\circ}$ (Figure 2.2C).

Given the differences in eddy viscosity profiles, the flow velocity profiles are also different for the two turbulence models for a flat bed (Figure 2.3). The tide-averaged flow velocity profiles $U_{M 0}$ both show small negative flow velocity amplitudes (Figure $2.3 \mathrm{~A}$ ), which will be shown to be much smaller than the tide-averaged flow velocity profiles for a wavy bed (residual circulation cell). Nevertheless, the small negative flow velocity amplitudes will induce a migration rate of the sand wave field in the order of centimeters per year (Section 2.3.3). The dominant flow velocity component $U_{M 2}$ shows a larger near-bed velocity for the constant vertical eddy viscosity model compared to the $k-\epsilon$ turbulence model (Figure 2.3B). The phase is comparable for both turbulence models (Figure 2.3C).

Next, we replace the flat bed with a wavy bed with a wavelength $L=600 \mathrm{~m}$ in order to study the hydrodynamic response. As shown by Hulscher (1996), due to the interaction of the flow with the wavy bed, the tide-averaged residual sea level is $180^{\circ}$ out of phase with the bottom perturbation. As a consequence, averaged over one tidal cycle, the flow velocity profiles show a residual circulation cell: tide-averaged flow velocities directed from the trough of the sand wave towards the crest near the bed for both turbulence models (Figure 2.4). In order to compare the results of the Delft3D model with an idealized sand wave model, we compare the residual circulation cell obtained with the Delft3D model with the residual circulation cell obtained with an idealized sand wave model of Van den Berg et al. (2012). In the model of Van den Berg et al. (2012) the eddy viscosity $\nu$, water depth $H$, wavelength $L$, flow velocity amplitude $U_{M 2}$, tidal frequency $\sigma_{M 2}$ and initial sand wave amplitude $A_{0}$ are chosen 

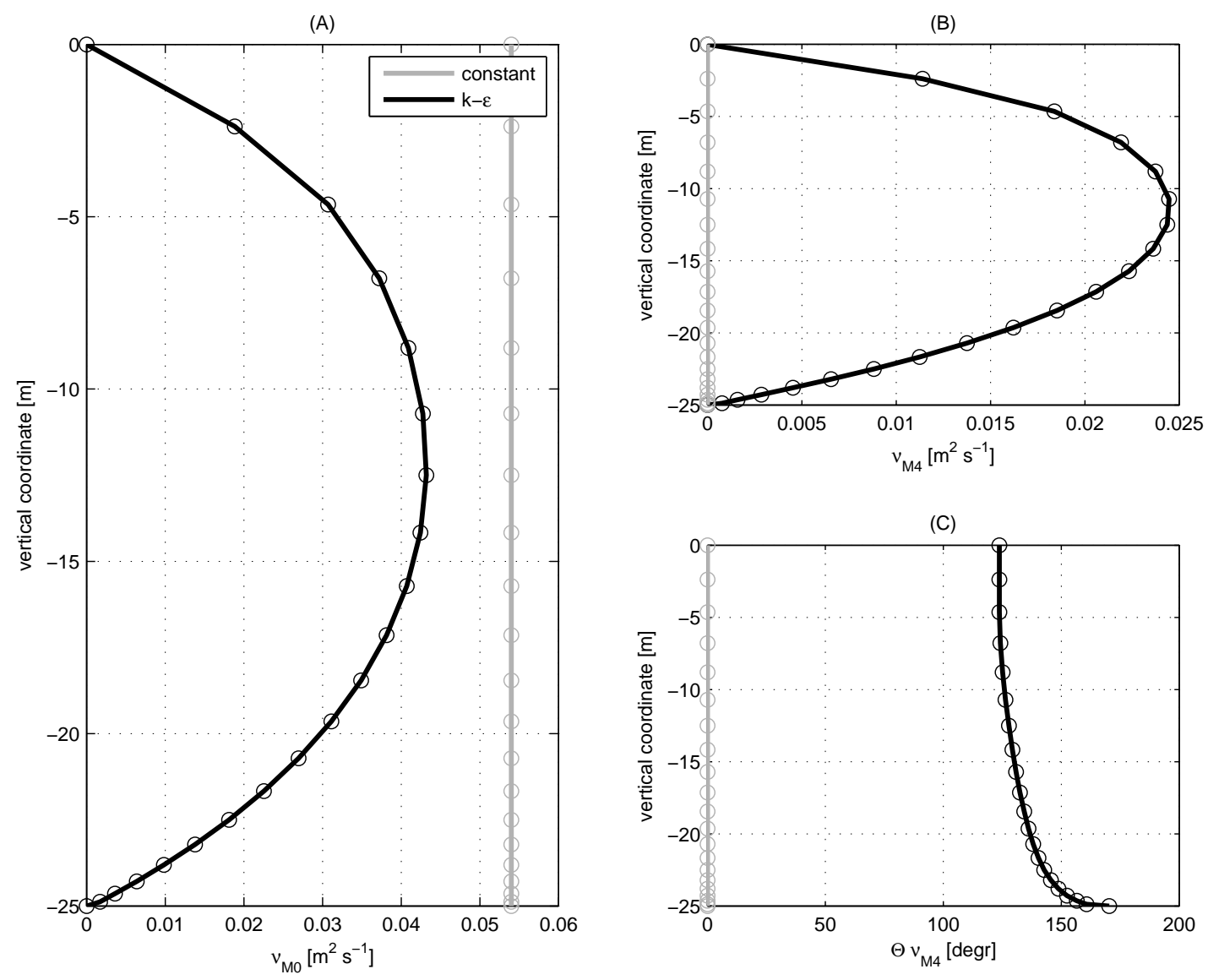

Figure 2.2: Eddy viscosity profiles $\nu\left[\mathrm{m}^{2} \mathrm{~s}^{-1}\right]$ for the constant vertical eddy viscosity model (gray line) and the $k-\epsilon$ turbulence model (black line). Tide-averaged values of the eddy viscosity $\nu_{M 0}\left[\mathrm{~m}^{2} \mathrm{~s}^{-1}\right](\mathrm{A})$ and the second harmonic eddy viscosity component $\nu_{M 4}\left[\mathrm{~m}^{2} \mathrm{~s}^{-1}\right](\mathrm{B})$ and phase $\theta \nu_{M 4}\left[^{\circ}\right](\mathrm{C})$ for a flat bed. (Case I in Table 2.1).

identical to our model set-up (Table 2.1; Case I). For all other parameter settings, the default parameters are taken (Van den Berg et al. (2012)). Comparison of the tideaveraged flow velocity profile $u_{M 0}\left[\mathrm{~m} \mathrm{~s}^{-1}\right]$ at the flank for the Delft3D model (Figure 2.4B; black line) with the idealized model by Van den Berg et al. (2012) (Figure 2.4B; gray line) shows good agreement. Especially the tide-averaged flow velocity amplitudes near the bed coincide. In conclusion, the numerical shallow water model adopted in this chapter is capable of reproducing the tide-averaged residual current as earlier found in the idealized model of Van den Berg et al. (2012).

Qualitatively, the residual circulation cells are similar for both turbulence models (Figure 2.4). However, compared to the constant vertical eddy viscosity model, the $k-\epsilon$ turbulence model shows weaker near-bed velocities and the centre of the residual circulation cell is found closer the bed. The strength of the residual circulation cell is small compared to the amplitude of the tidal velocity. However, the strength of the tide-averaged flow velocity near the bed is much larger for the wavy bottom case (Figure 2.4B and Figure 2.4D), compared to the flat bed (Figure 2.3A). 

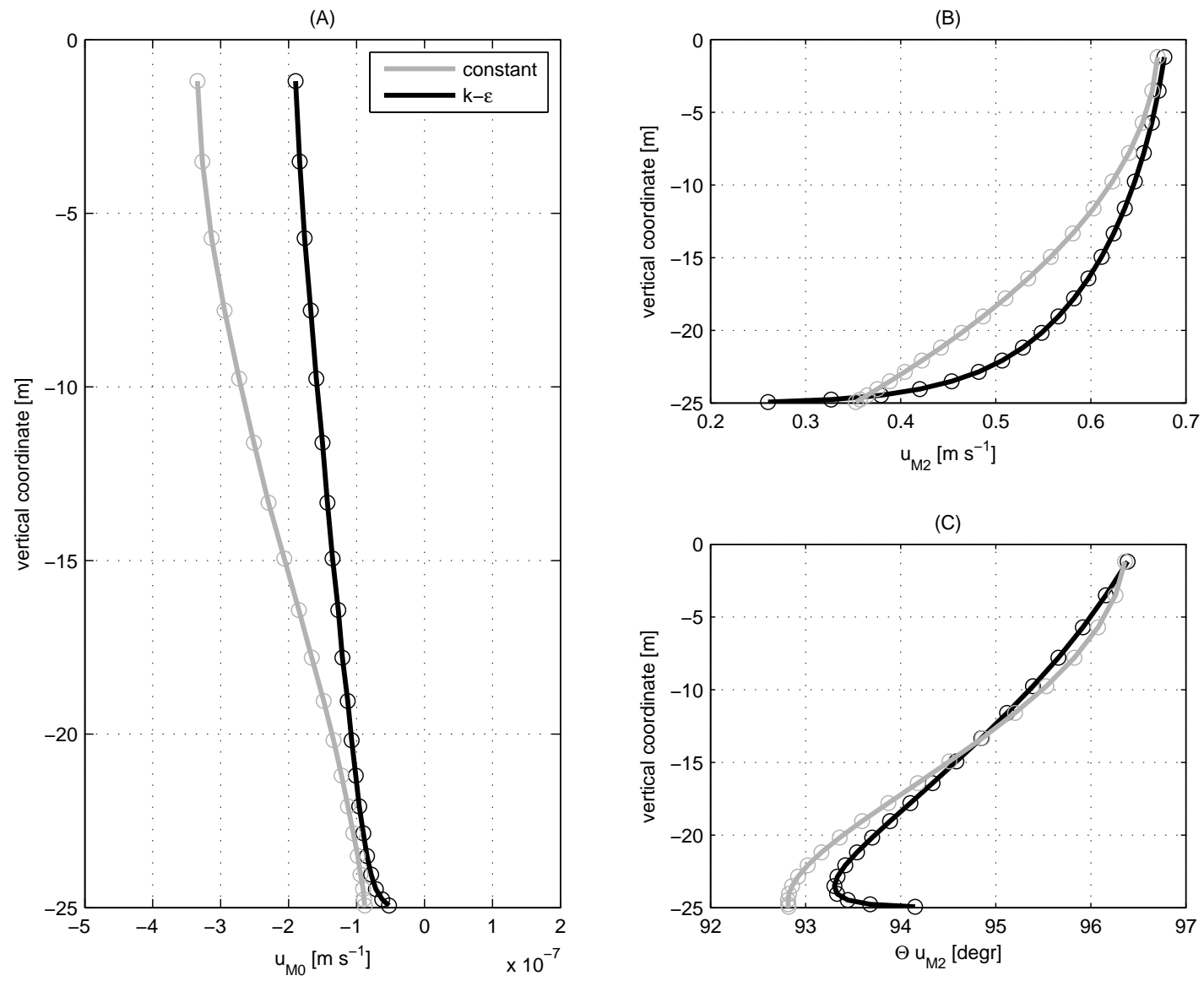

Figure 2.3: Flow velocity profiles $u\left[\mathrm{~m} \mathrm{~s}^{-1}\right]$ for the constant vertical eddy viscosity model (gray line) and the $k-\epsilon$ turbulence model (black line). Tide-averaged values of the flow velocity $u_{M 0}\left[\mathrm{~m} \mathrm{~s}^{-1}\right](\mathrm{A})$ and the first harmonic flow velocity component $u_{M 2}$ [m s$s^{-1}$ (B) and phase $\theta u_{M 2}$ [degr] (C) for a flat bed. (Case I in Table 2.1).

\subsubsection{Bed evolution}

Now let us investigate the growth rate as a function of the topographic wave number $k$ $=2 \pi / L$, for both turbulence models, and isolating the contributions due to the plain bedload transport (neglecting slope-induced transport) and the slope-induced transport (Case I Table 2.1). We have varied the wavelength $L$ in a range of $160 \mathrm{~m}$ till $4500 \mathrm{~m}$ (Table 2.1). Assuming exponential growth (which is valid for small-amplitude sand waves (Besio et al., 2008)), the growth rate $\gamma_{R}$ for the bed perturbation is calculated by:

$$
\gamma_{R}=\frac{1}{T} \Re\left[\log \left(\frac{A_{1}}{A_{0}}\right)\right],
$$

where $T$ is the tidal period, $A_{1}$ is the bed amplitude of the sand wave after one tidal cycle of morphodynamic computation. $A_{1}$ is determined by a Fast Fourier Transform (FFT) of the central part of the sand wave domain. Positive values of $\gamma_{R}$ indicate growth of the bottom perturbation, whereas negative values indicate decay.

Given the direction of the tide-averaged near-bed velocities, a small net transport 

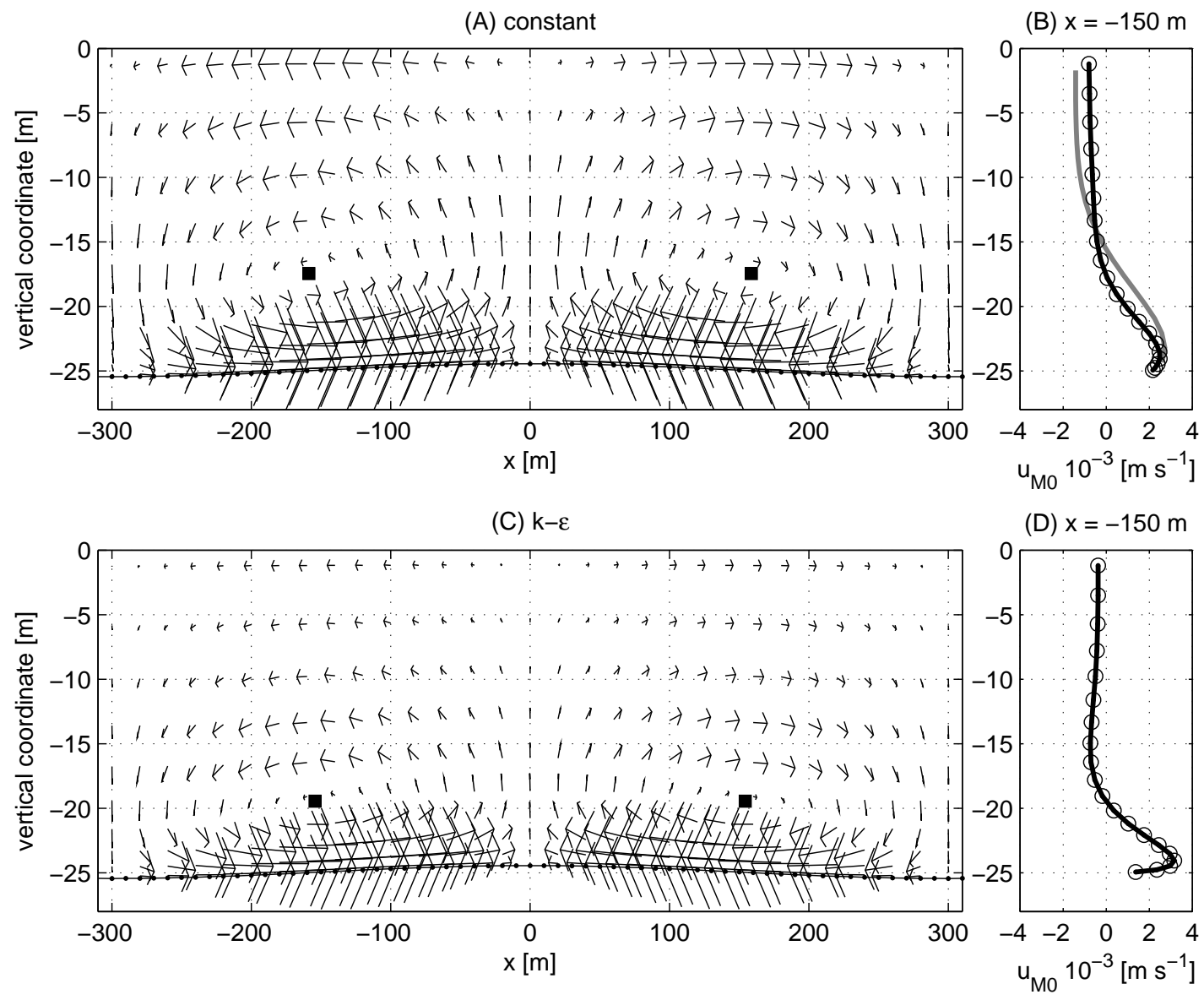

Figure 2.4: Tide-averaged residual current over a sand wave with wavelength $L=600$ $\mathrm{m}$, for a simulation with the constant vertical eddy viscosity model (A) and the $k-\epsilon$ turbulence model $(\mathrm{C})$. The centre of the residual circulation cell is indicated with a black square. Tide-averaged flow velocities profiles $u_{M 0}\left[\mathrm{~m} \mathrm{~s}^{-1}\right]$ are shown at the flank $x=-L / 4=-150 \mathrm{~m}$ for the constant vertical eddy viscosity (B) and $k-\epsilon$ turbulence model (D). (Case I in Table 2.1). The tide-averaged flow velocity profile $u_{M 0}\left[\mathrm{~m} \mathrm{~s}^{-1}\right]$ at the flank for the idealized model by Van den Berg et al. (2012) is shown with the gray line (B).

of sediment directed from the trough towards the crest of the sand wave is expected when slope-induced transport is neglected. For a given wavelength of the sand wave, water depth and flow velocity amplitude, the strength of the residual circulation cell can be determined. In general, the sand wave with the largest wave number causes the strongest residual circulation cell. Consequently, neglecting the slope-induced transport, the sand wave with the smallest wavelength shows the largest growth rate, for both turbulence models (Figure 2.5A). However, the growth rate for the constant vertical eddy viscosity model is larger, due to the stronger tide-averaged near-bed velocities for a given wave number.

Due to the slope effect, the sand wave tends to decay. The slope-induced transport is the strongest for large wave numbers. The slope of the bed form is equal for both simulations for a given wave number, but the magnitude of the transport rate is much 

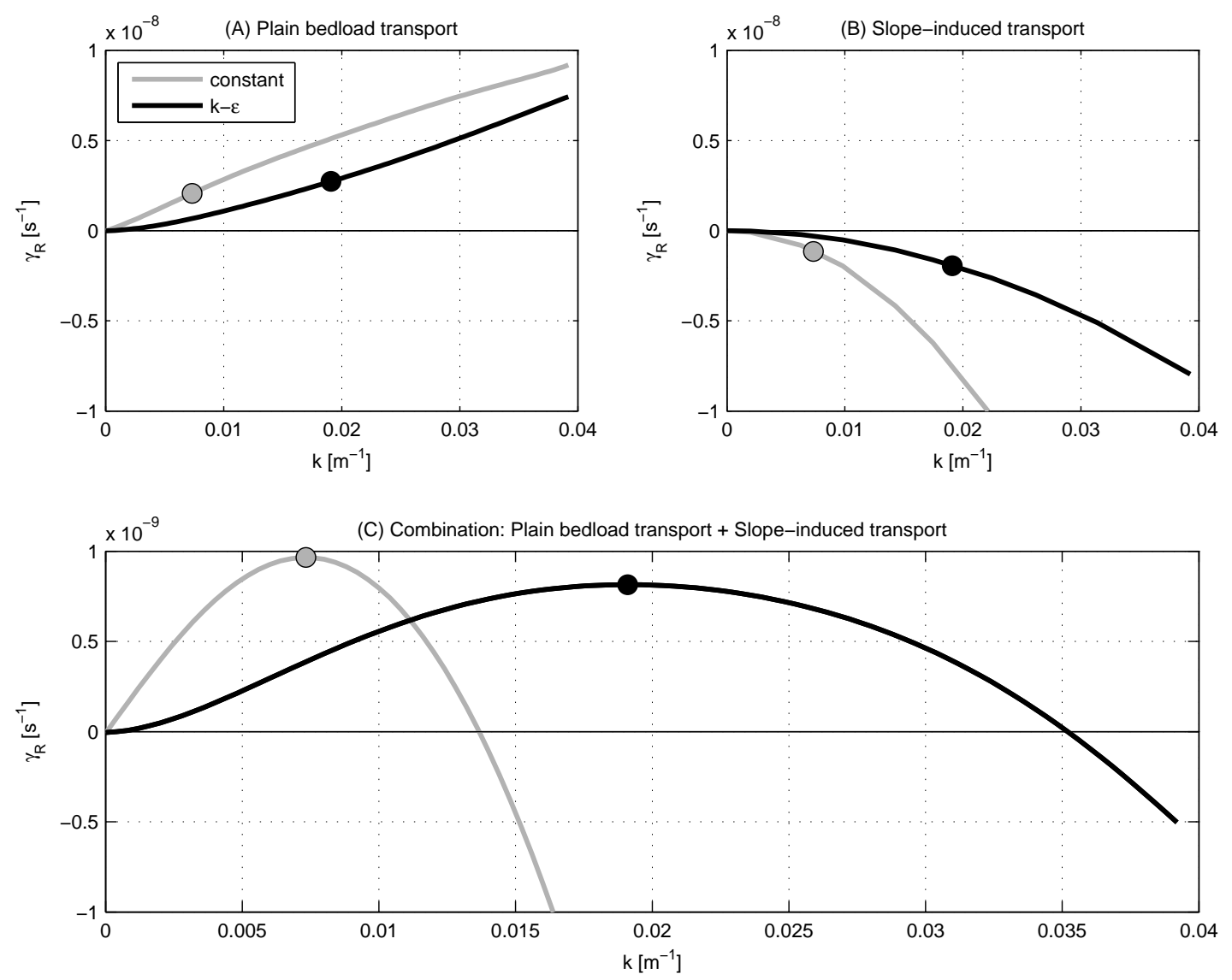

Figure 2.5: The total growth rate curve $(\mathrm{C})$ is the sum of the plain bedload transport component (A) and the slope-induced transport component (B). On the horizontal axis the wave number $k\left[\mathrm{~m}^{-1}\right]$ is given and on the vertical axis the growth rate $\gamma_{R}\left[\mathrm{~s}^{-1}\right]$. The circles indicate the growth rates belonging to the fastest growing mode $L_{F G M}$. Two turbulence models are shown: constant vertical eddy viscosity (gray line) and $k-\epsilon$ turbulence model (black line). (Case I in Table 2.1).

larger for the constant vertical eddy viscosity model, resulting in a stronger slopeinduced transport (Figure 2.5B).

The total growth curve is the sum of the plain bedload transport and the slopeinduced transport (Figure 2.5C). The fastest growing mode is the wave number which triggers the fastest initial growth. In conclusion, the wavelength for the fastest growing mode for the constant vertical eddy viscosity model is much larger $\left(L_{F G M}=870 \mathrm{~m}\right)$, compared to the $k-\epsilon$ turbulence model $\left(L_{F G M}=330 \mathrm{~m}\right)$.

\subsubsection{Migration}

For a symmetrical forcing, sand waves do not migrate. However, if a residual current $U_{M 0}$ or another tidal component (e.g. the quarter-diurnal $\mathrm{M}_{4}$-tidal component) is present next to the semi-diurnal tidal component $\mathrm{M}_{2}$, the sand waves may display migration (Németh et al., 2002; Besio et al., 2004). Typical values for the residual current $U_{M 0}$ and the amplitude of the $\mathrm{M}_{4}$-tidal component $U_{M 4}$ are $0.05 \mathrm{~m} \mathrm{~s}^{-1}$ for the North Sea (Besio et al., 2004). The phase lag between the $\mathrm{M}_{2}$ and $\mathrm{M}_{4}$-tidal component 
determines the direction of migration (Besio et al., 2004), whereas the residual current causes sand waves to migrate always in the downstream direction (Németh et al., 2002). Besio et al. (2004) showed that for a phase lag of $120^{\circ}$ between the $\mathrm{M}_{2}$ and $\mathrm{M}_{4}$-tidal component sand wave migration in the upstream direction is possible.

In this section we show the results for four simulations. The first two simulations are the inclusion of a residual current $U_{M 0}$ of $0.05 \mathrm{~m} \mathrm{~s}^{-1}$ on top of the default model settings (Case II in Table 2.1) for both turbulence models. The next two simulations are the inclusion of a $\mathrm{M}_{4}$-tidal component of $U_{M 4}=0.05 \mathrm{~m} \mathrm{~s}^{-1}$ and a phase lag $\phi=$ $120^{\circ}$ between the $\mathrm{M}_{2}$ and $\mathrm{M}_{4}$-tidal component for both turbulence models (Case III in Table 2.1). Sand wave migration implies that $A_{1}$ is a complex quantity and the migration rate $\gamma_{I}$ of the sand wave is calculated by:

$$
\gamma_{I}=\frac{-1}{k T} \Im\left[\log \left(\frac{A_{1}}{A_{0}}\right)\right] .
$$

By including a residual current $U_{M 0}$, the sand wave shows a positive migration rate, which means migration in the direction of the residual current. For the fastest growing mode the migration speed $\gamma_{I}=9 \mathrm{~m}$ year $^{-1}$ for the constant vertical eddy viscosity model (Figure 2.6B black circle), while for the $k-\epsilon$ turbulence model, the migration
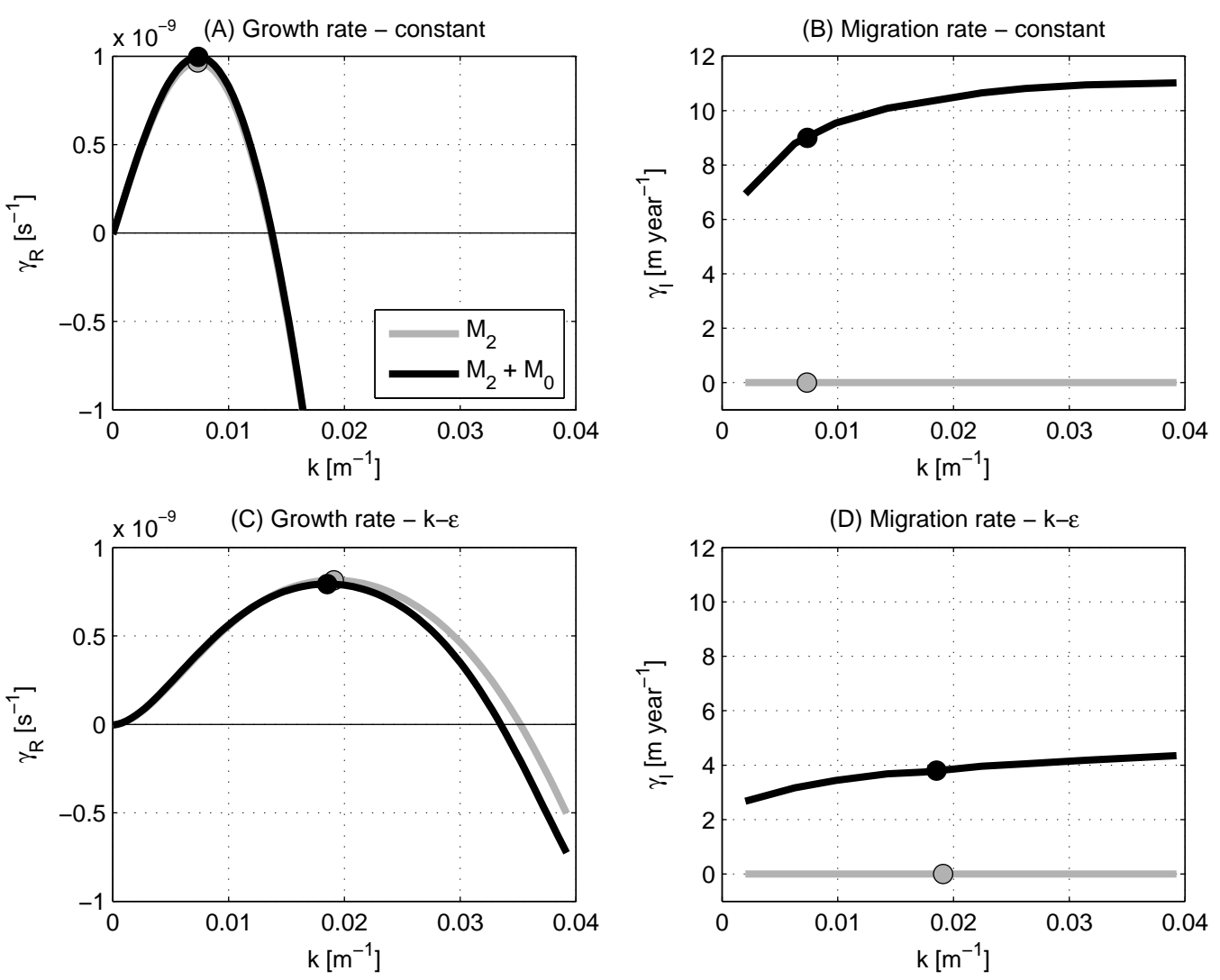

Figure 2.6: Growth rate $\gamma_{R}\left[\mathrm{~s}^{-1}\right]$ and migration rate $\gamma_{I}\left[\mathrm{~m}\right.$ year $\left.{ }^{-1}\right]$ as a function of wave number $k\left[\mathrm{~m}^{-1}\right]$, for constant vertical eddy viscosity (top) and $k-\epsilon$ (bottom). Distinction is made between only $\mathrm{M}_{2}$ tidal forcing (gray line) and combined $\mathrm{M}_{2}$ and $\mathrm{M}_{0}$ tidal forcing (black line). The circles indicate the growth rates and migration rates belonging to the fastest growing modes $L_{F G M}$. (Case II in Table 2.1). 
rate for the fastest growing mode $\gamma_{I}=3.8 \mathrm{~m} \mathrm{year}^{-1}$ (Figure $2.6 \mathrm{D}$ black circle). As expected, the migration rate for the symmetrical forcing $\left(\mathrm{M}_{2}\right.$-tidal component) is nearly zero (order of centimeters per year: Figure 2.6B and Figure 2.6D gray circles). The growth curves are nearly identical for both turbulence models (Figure 2.6A and Figure $2.6 \mathrm{C}$ ), indicating that the inclusion of a small residual current will not change the strength of the residual circulation cell and hence the fastest growing mode. The larger migration rate for the constant vertical eddy viscosity model is caused by the larger transport rates compared to the $k-\epsilon$ turbulence model.

By including a $\mathrm{M}_{4}$-tidal component with a phase lag $\phi=120^{\circ}$ with the $\mathrm{M}_{2}$-tidal component, the sand wave shows a negative migration rate, which means migration in the upstream direction (Figure 2.7). For the fastest growing mode the migration speed $\gamma_{I}=-1.9 \mathrm{~m} \mathrm{year}^{-1}$ for the constant vertical eddy viscosity model (Figure 2.7B black circle), while for the $k-\epsilon$ turbulence model, the migration rate for the fastest growing mode $\gamma_{I}=-1.1 \mathrm{~m} \mathrm{year}^{-1}$ (Figure 2.7D black circle). Again, the migration rate for the symmetrical forcing $\left(\mathrm{M}_{2}\right)$ is nearly zero (Figure 2.7B and Figure 2.7D gray circles) and the growth curves are nearly identical for both turbulence models (Figure 2.7A and Figure 2.7C).
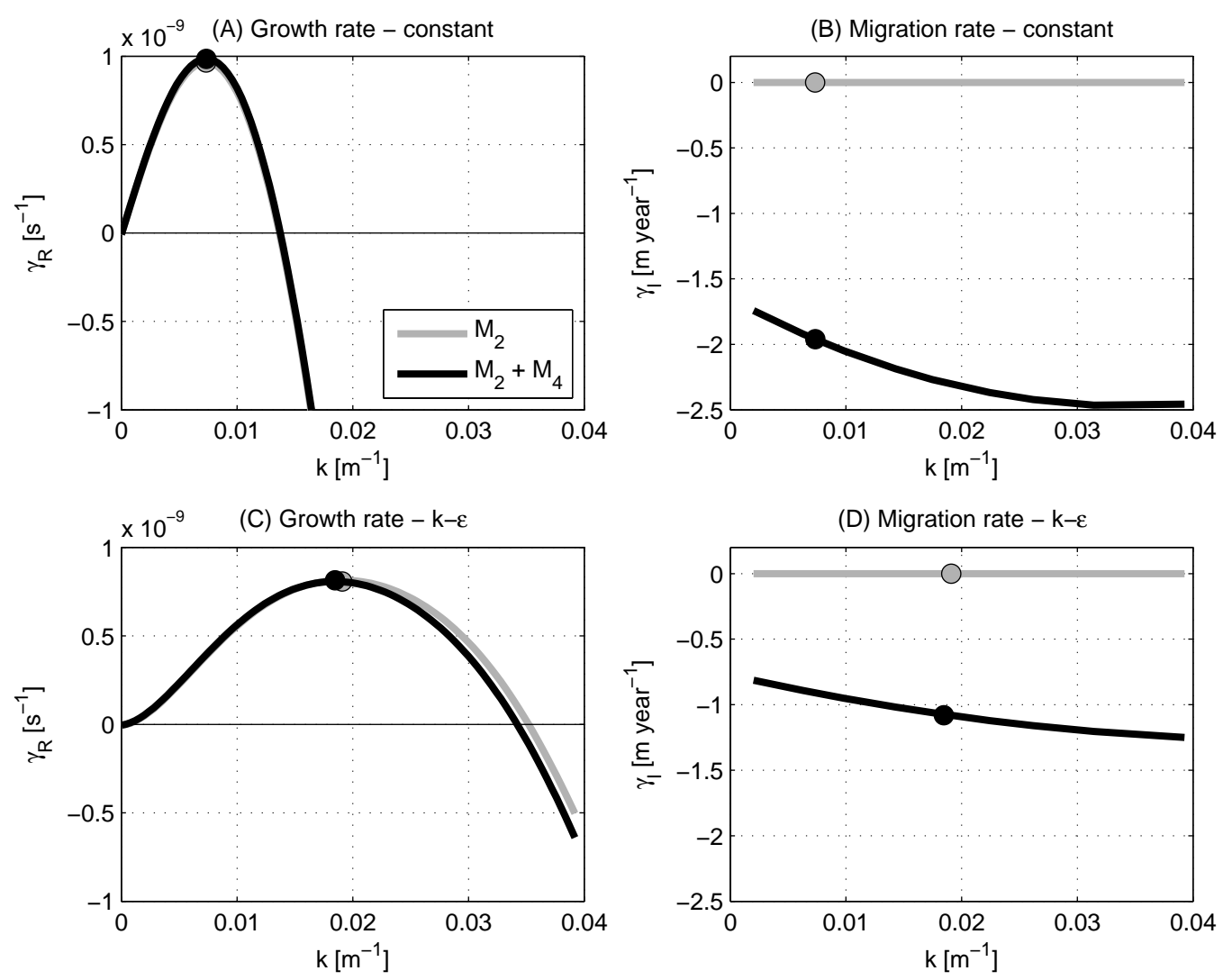

Figure 2.7: Growth rate $\gamma_{R}\left[\mathrm{~s}^{-1}\right]$ and migration rate $\gamma_{I}\left[\mathrm{~m}\right.$ year $\left.^{-1}\right]$ as a function of wave number $k\left[\mathrm{~m}^{-1}\right]$, for constant vertical eddy viscosity (top) and $k-\epsilon$ (bottom). Distinction is made between only $\mathrm{M}_{2}$ tidal forcing (gray line) and combined $\mathrm{M}_{2}$ and $\mathrm{M}_{4}$ tidal forcing (black line). The circles indicate the growth rates and migration rates belonging to the fastest growing modes $L_{F G M}$. (Case III in Table 2.1). 

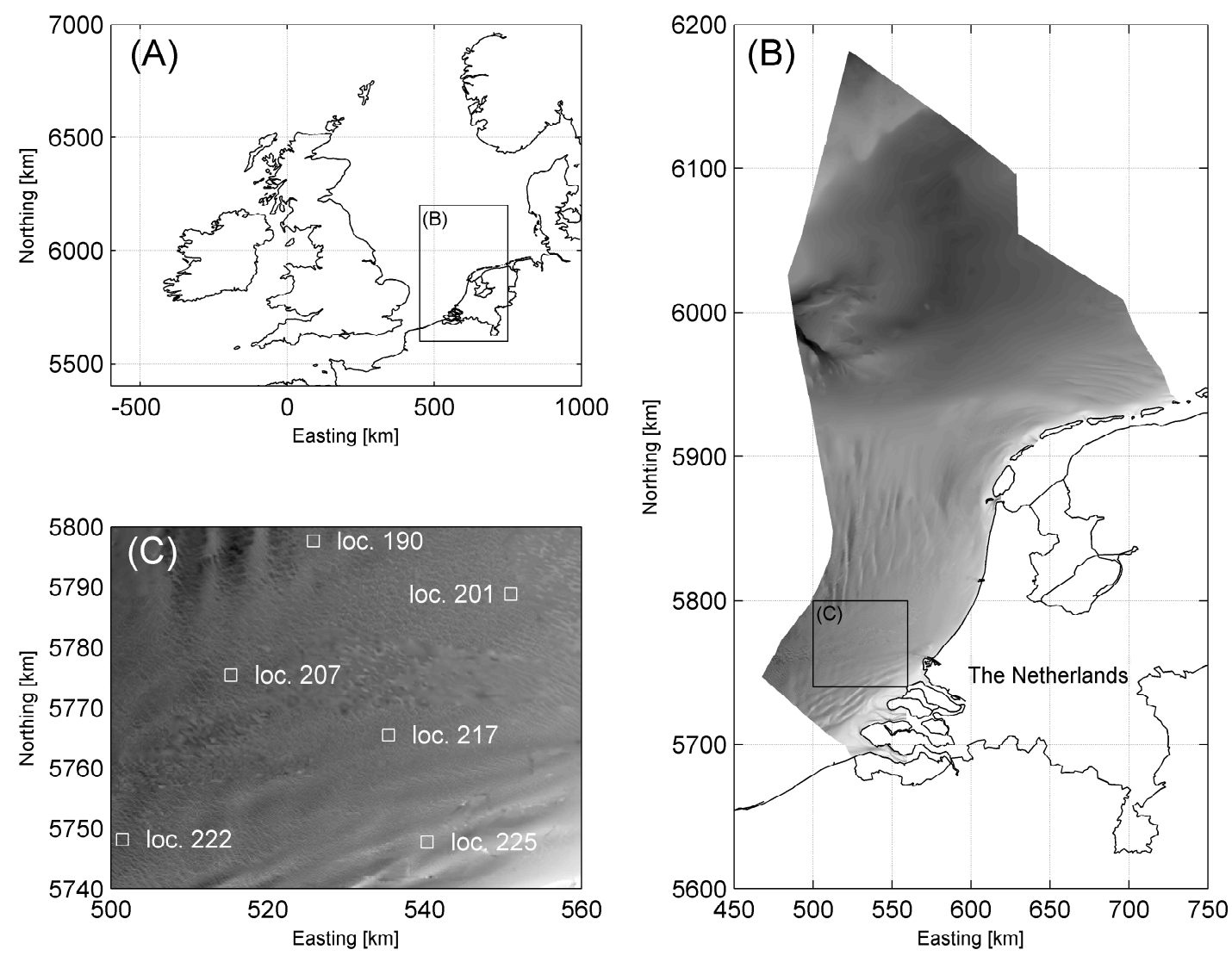

Figure 2.8: Location of sand wave fields (C) used in the comparison of the model results, located in the Dutch part of the North Sea (B) in North-West Europe (A).

\subsection{Comparison of model results with sand wave lengths in the Southern North Sea}

The results of the model are compared with field data on sand wave length on the Dutch Continental Shelf (Figure 2.8B). Comparison of the migration rates found in the model with field data is difficult, as the standard deviation in migration rates is in the same order as the average migration rate in the field (Besio et al., 2004). Nevertheless, the range in migration rates found in the simulations is comparable to field observations for the North Sea (Dorst et al., 2009). Recently, Van Santen et al. (2011) presented an overview of 23 locations where sand waves are found on the Dutch continental shelf for which the flow velocity amplitude $U_{M 2}$, grain size $d$, mean water depth $H_{0}$ and sand wave length $L$ is given. Because only bedload transport is included in the model, six locations are selected (Figure 2.8C) which are located in a mean water depth $H_{0}$ of around 30 meters, a flow velocity amplitude $U_{M 2}$ of around $0.70 \mathrm{~m} \mathrm{~s}^{-1}$ and a grain size $d$ of around $0.32 \mathrm{~mm}$ (Table 2.2). As a result, bedload transport is expected to be the dominant transport mechanism. The range in fastest growing mode is determined for both turbulence models by taking the mean of two of the three parameters and taking either the maximum or the minimum of the third parameter (Table 2.2). The result of the simulation in which the $k-\epsilon$ turbulence model is used agrees much better with the field data compared to the constant vertical eddy viscosity model (Figure 2.9). 
Table 2.2: Mean wavelength $L$ of sand wave fields at six locations in the Dutch part of the North Sea. Data on the amplitude of the flow velocity $U_{M 2}$, mean water depth $H_{0}$, grain size $d$ and mean wavelength $L$ are given by Van Santen et al. (2011). Location numbers correspond to the numbers shown in Figure 2.8.

\begin{tabular}{lllll}
\hline Location no. & $U_{M 2}\left[\mathrm{~m} \mathrm{~s}^{-1}\right]$ & $H_{0}[\mathrm{~m}]$ & $d[\mathrm{~mm}]$ & $L[\mathrm{~m}]$ \\
\hline '225' & 0.70 & 21.33 & 0.36 & 220 \\
'222' & 0.73 & 34.63 & 0.34 & 490 \\
'217' & 0.68 & 29.30 & 0.27 & 290 \\
'207' & 0.72 & 31.51 & 0.28 & 320 \\
'201' & 0.64 & 25.70 & 0.36 & 400 \\
'190' & 0.65 & 30.59 & 0.32 & 290 \\
\hline Range & {$[0.64-0.73]$} & {$[21.33-34.63]$} & {$[0.27-0.36]$} & {$[220-490]$} \\
\hline Mean & 0.69 & 28.84 & 0.32 & 335 \\
\hline
\end{tabular}

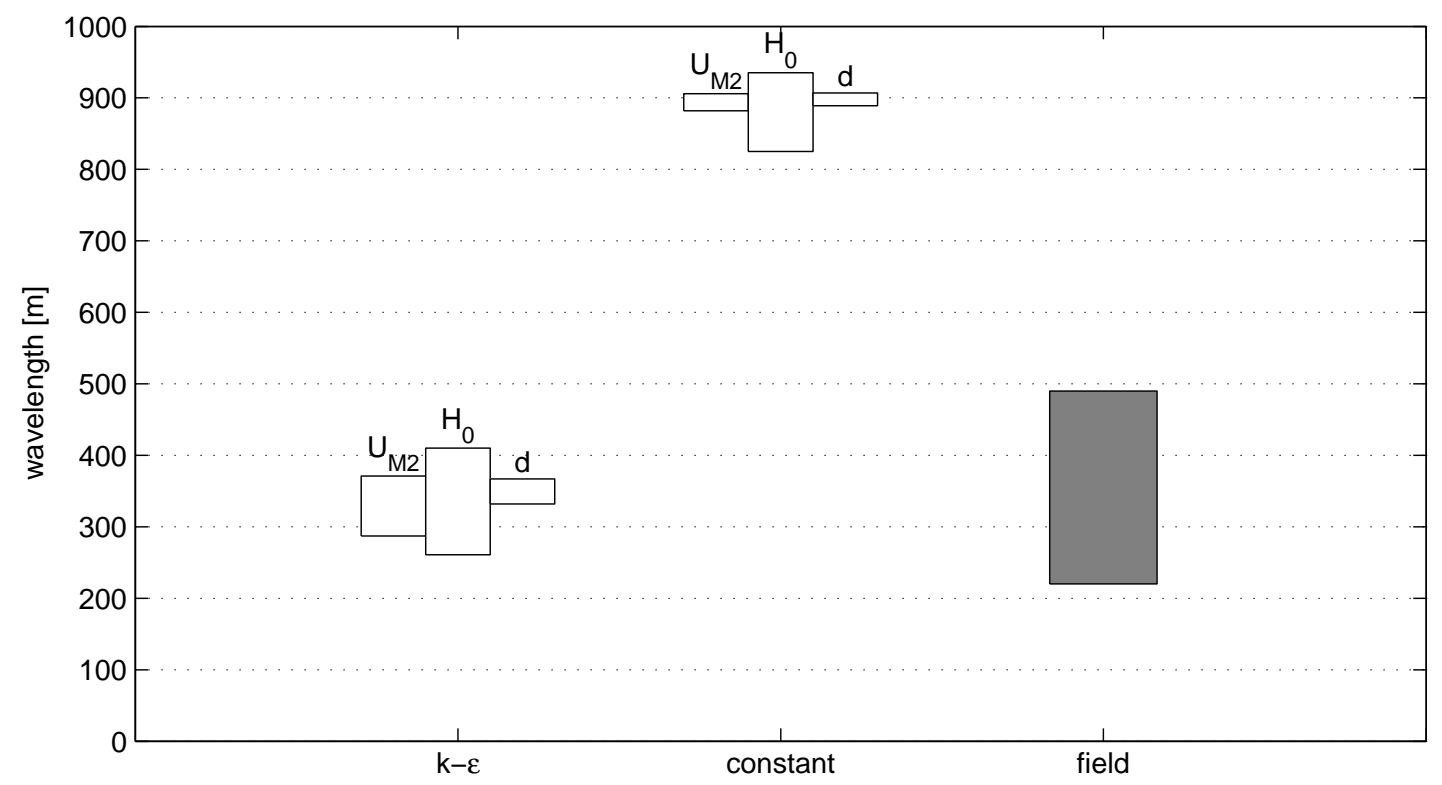

Figure 2.9: Range in fastest growing mode for both turbulence models, by taking either the maximum or the minimum in flow velocity amplitude $U_{M 2}$, mean water depth $H_{0}$ and grain size $d$ while taking the mean of the other parameters (Table 2.2). The gray bar indicates the variation in wavelength $L$ measured in the field, as given by Van Santen et al. (2011).

\subsection{Discussion}

This chapter presents simulations with the numerical shallow water model Delft3D, in which the initial stage of sand wave formation has been reproduced. The formation of sand waves, extensively studied with idealized models, has never been reproduced in a numerical shallow water model before. The main difficulty in reproducing sand wave formation in a numerical shallow water model is the reflection of the tidal wave by the imposed lateral boundary. In engineering practice, Delft3D is usually run with a flow velocity at one lateral boundary and a water level at the opposite lateral boundary (e.g. Tonnon et al., 2007). Because these lateral boundary conditions are reflective, a small 
net tide-averaged current will be present in the modeling domain. The magnitude of this reflective net current is in the same order of magnitude as the net current induced by the bottom topography (see the residual circulation cells in Figure 2.4). In this study, Riemann lateral boundary conditions have been used instead, in which outgoing waves can cross the open boundary without being reflected back into the computation domain.

The resolution used to reproduce sand wave formation is $10 \mathrm{~m}$ in horizontal direction in the sand wave domain and 20 layers in vertical direction, for which the layers close to the bed have a vertical resolution in the order of ten centimeters. The fine horizontal resolution is necessary to have enough grid cells to cover the smallest sand waves modeled $\left(L_{\min }=160\right.$ meter $)$. The fine vertical resolution is necessary to model the strong gradient in flow velocity profile near the bed (Figure 2.4). For a finer vertical resolution near the bed the results were the same, whereas for a coarser vertical resolution near the bed, the flow velocities near the bed were overestimated, resulting in slightly longer sand waves.

The overestimation in wavelength of sand waves by using a constant vertical eddy viscosity is often corrected for by increasing the bed roughness (e.g. Van Santen et al., 2011; Sterlini et al., 2009; Németh et al., 2002). An increase in bed roughness causes a steeper gradient in flow velocity near the bed, and therefore a flow velocity profile which matches the velocity profile calculated with the $k-\epsilon$ turbulence model better. Nevertheless, by increasing the roughness of the bed, both the bed shear stress and the bedload transport rate increase. Consequently, the fastest growing mode could be matched for the two different turbulence models (Figure 2.10). However, by increasing the bed roughness, the migration rate will increase to unrealistic values, as discussed by Sterlini et al. (2009) and Németh et al. (2002), up to $150 \mathrm{~m} \mathrm{year}^{-1}$. Moreover, the bed roughness is not an independent parameter, the value depends on the grain size and, when ripples form, on hydrodynamic conditions. Therefore, correcting the overestimation in wavelength for idealized models with a constant eddy viscosity by increasing the bed roughness will not only result in unrealistic high migration rates but is also physically incorrect.

The results of the numerical shallow water model are comparable to the results of idealized models (Besio et al., 2008): sand waves with a wavelength in the order of several hundreds of meters and a growth rate in the order of $10^{-2}$ year $^{-1}$ are found. However, the main difference between both type of models is the shape of the growth curve near $k=0$ (Figure 2.5C). The growth curve for idealized models and the numerical shallow water model with constant vertical eddy viscosity is concave, while the growth curve for the numerical shallow water model in which a $k-\epsilon$ turbulence model is adopted is convex. As a consequence, the growth rate for very long sand waves is much smaller for the $k-\epsilon$ turbulence model, compared to the constant vertical eddy viscosity model. For a wavelength of e.g. $L=3000 \mathrm{~m}$ the growth rate for the $k-\epsilon$ turbulence model is 10 times smaller, but still shows a positive growth rate (Figure 2.5C). So far, the $k-\epsilon$ turbulence model did not damp the long sand waves as shown in Komarova and Hulscher (2000). However, the numerical shallow water model presented in this chapter contains many additional processes, so that it is a good starting point to investigate the damping of long sand waves further, starting with the role of suspended sediment on sand wave formation. Moreover, a next step is to run the model for a longer period and study the mechanisms which control the equilibrium shape of sand waves. 


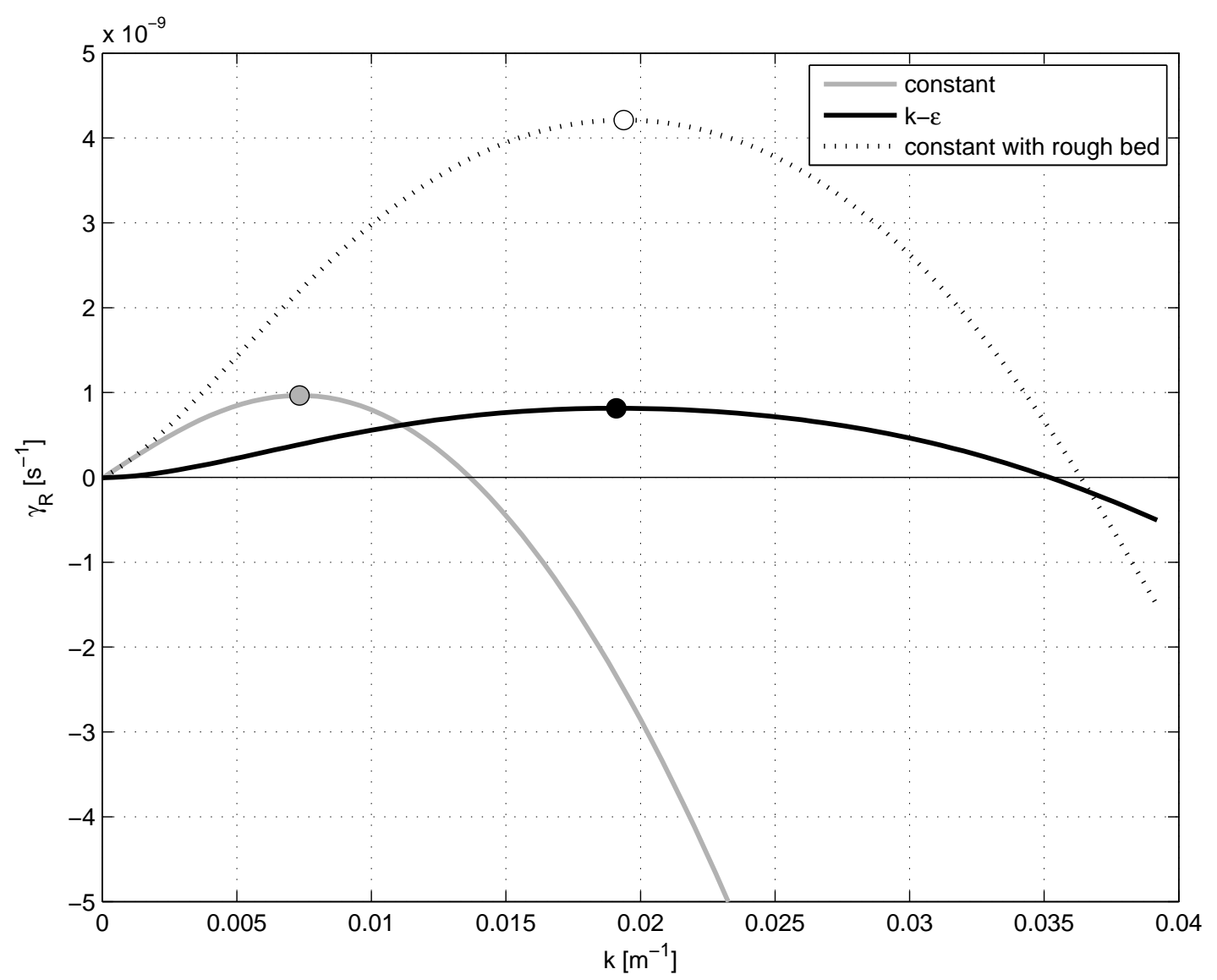

Figure 2.10: Total growth curve and fastest growing mode for the constant vertical eddy viscosity model (gray line - gray circle), $k-\epsilon$ turbulence model (black line - black circle) and the constant vertical eddy viscosity model with a rough bed (black dashed line - white circle). Chézy roughness $C=65 \mathrm{~m}^{1 / 2} \mathrm{~s}^{-1}$ and $C=48 \mathrm{~m}^{1 / 2} \mathrm{~s}^{-1}$ for the default case and the rough bed case respectively. (Case I in Table 2.1). 


\subsection{Conclusions}

The initial stage of tidal sand wave formation has been successfully reproduced in a numerical shallow water model (Delft3D). In order to resolve the tide-averaged vertical residual current over a sand wave, non-reflective lateral boundaries and a high resolution both in time and space is needed.

The model has been run with two turbulence models: constant vertical eddy viscosity and an advanced spatially and temporally variable vertical eddy viscosity model ( $k-\epsilon$ turbulence model). For the same tidal conditions, the constant vertical eddy viscosity model showed higher tide-averaged near-bed velocities, and consequently caused longer sand waves and higher migration rates compared to the $k-\epsilon$ turbulence model.

Next, we compared field data on sand wave length of the Southern North Sea with the results of both turbulence models. The $k-\epsilon$ turbulence model showed good agreement with the field data, whereas the constant vertical eddy viscosity model overestimates the wavelength of the sand waves considerably.

The spatially and temporally variable vertical eddy viscosity caused much smaller growth rates for long sand waves compared to idealized models in which the vertical eddy viscosity is time independent. However, both for idealized models and the $k-\epsilon$ turbulence model the growth rates for long sand waves were still positive. Future research will study whether the inclusion of suspended sediment in combination with a $k-\epsilon$ turbulence model will lead to negative growth rates for long sand waves. 


\title{
Chapter 3
}

\section{The role of suspended load transport in the occurrence of tidal sand waves}

This chapter is based on the paper:

B.W. Borsje, W.M. Kranenburg, P.C. Roos, J. Matthieu, S.J.M.H. Hulscher. The role of suspended load transport in the occurrence of tidal sand waves, under review.

\begin{abstract}
Tidal sand waves are dynamic bed patterns which are formed by the complex interaction among hydrodynamics, sediment transport and morphology. Field data from the Southern North Sea show that sand waves are absent where suspended load transport is the dominant transport mode. In order to understand the mechanisms responsible for the absence of sand waves, we study the influence of suspended sediment on the formation of tidal sand waves with a numerical shallow water model (Delft3D). Model simulations are presented in which both the vertical eddy viscosity and the vertical sediment diffusivity are spatially and temporally variable $(k-\epsilon$ turbulence model). First, it is shown that the preferred wavelength of sand waves for a relatively large grain size is hardly influenced by the inclusion of suspended sediment, whereas for a relatively small grain size the flat bed is stable and no sand waves evolve. Secondly, it is shown that suspended load transport causes the damping of long sand waves, resulting in a finite range of wavelengths that experience growth. Finally, by varying flow velocity amplitude and grain size, critical conditions for sand wave formation are found. Comparison of these critical conditions with field data on the occurrence of sand waves shows good agreement.
\end{abstract}




\subsection{Introduction}

Sand waves are rhythmic bed patterns which are found on the bed of sandy shallow seas. The wavelengths of these bed patterns are up to hundreds of meters, the heights are several meters and the migration rates are up to several meters per year (McCave, 1971; Terwindt, 1971; Huntley et al., 1993). Sand waves are observed in many tide-dominated sandy shallow shelf seas like the North Sea, Bisanseto Sea, Irish Sea, the shelf off Spain and Argentina and in many straits and tidal inlets around the world (Van Santen et al., 2011 and references herein). It is the combination of dimensions, dynamics and occurrence that makes tidal sand waves a practically relevant marine bed pattern. Moreover, human activities like maintaining navigation channels and constructing pipelines and telecommunication cables may interact with the dynamic character of the sand waves (Németh et al., 2003). Therefore, insight in the processes controlling the variation in tidal sand wave dynamics is essential for cost-effective management practices.

Field observations indicate a relation between suspended load transport and sand wave growth. Along the Dutch coast, McCave (1971) observed a decrease in both sand wave height and the prevalence of super-imposed megaripples in space. He attributed this to a decrease in sediment size and consequently an increase in suspended load transport. Later, the damping effect of suspended load transport on sand wave height was also found in observational studies worldwide by e.g. Rubin and McCulloch (1980), Ernsten et al. (2005) and Buijsman and Ridderinkhof (2008). These observations motivate us to study the physical mechanisms responsible for the damping of sand waves by suspended load transport.

The formation of sand waves has been explained as a free instability of the sandy seabed subject to tidal motion. Hulscher (1996) showed that the interaction of the oscillatory tidal current with a bottom perturbation gives rise to a tide-averaged residual circulation directed from the trough towards the crest of the sand wave. This residual circulation induces a net bedload sediment flux towards the crest of sand waves, which leads to sand wave growth if the sediment transport overcomes the opposing effect of gravity. It is this competition between destabilizing and stabilizing sediment fluxes that defines a preferred wavelength, termed the fastest growing mode (FGM). Gerkema (2000) and Besio et al. (2003) extended the model of Hulscher (1996) by focusing on the hydrodynamic solution method. To explain sand wave migration, Németh et al. (2002) and Besio et al. (2004) introduced a residual current and tidal asymmetry, respectively. Németh et al. (2007) and Sterlini et al. (2009) proposed a non-linear model in which the sand wave behavior is modeled from its initial stage until an equilibrium shape. In all the models mentioned above only bedload transport is included and the turbulent stresses are accounted for by combining a constant vertical eddy viscosity with a partial slip condition at the bed. Komarova and Hulscher (2000) extended the model of Hulscher (1996) by introducing a time dependency in the vertical eddy viscosity, while retaining only bedload transport. Blondeaux and Vittori (2005ab) and Besio et al. (2006) introduced a depth dependent eddy viscosity profile and a no-slip condition at the bed. Moreover, suspended sediment dynamics were included in the model. The results of the model showed that sediment carried in suspension indeed provides a damping effect on the growth rate of sand waves. However, the physical mechanism responsible for the damping effect due to suspended load transport has not been explained.

The dynamics of the suspended load transport are known to be complex given 
the vertical sediment diffusivity involved in the transport equation of suspended load transport. In the models by Blondeaux and Vittori (2005ab) and Besio et al. (2006), the vertical sediment diffusivity only depends on the height from the bed. The numerical shallow water model used by Borsje et al. (2012a; Chapter 2) accounts for both spatially and temporally varying vertical sediment diffusivity and therefore we consider this a good starting point to further investigate the role of suspended load transport on the initial stage of formation of sand waves. Next to that, based on field observations sand waves are known to have a limited range in wave lengths (e.g. Van Santen et al., 2011). Whereas slope-induced transport is able to suppress short sand waves, we are also interested in particularly a mechanism which is able to suppress long sand waves. Up to now, models fail to suppress the growth of very long sand waves, and simulations on a large spatial domain show that the sand wave field finally evolves towards one large bedform with a wavelength equal to the domain length (Sterlini et al., 2009), indicating that the essential physical mechanisms are not yet fully understood. As shown by Borsje et al. (2012a; Chapter 2), the spatially and temporally variable vertical eddy viscosity $(k-\epsilon$ turbulence model) already causes much smaller growth rates for long sand waves compared to idealized models in which the vertical eddy viscosity is time independent. However, the growth rates for long sand waves were still positive. Whether the inclusion of suspended sediment in combination with a $k-\epsilon$ turbulence model will lead to negative growth rates for long sand waves will be investigated in this chapter.

The aim of this chapter is twofold. First of all, based on field observations we aim to further investigate the role of suspended load transport in the occurrence of sand waves in the field. Secondly, we aim to understand the role of suspended load transport in sand wave formation and occurrence with help of a numerical shallow water model (Delft3D). We compare the model results with field data on sand wave occurrence in the Southern North Sea.

\subsection{Field data on sand wave occurrence and transport re- gime}

Field observations suggest a relation between transport regime and the occurrence of sand waves (McCave, 1971). To quantify the transport regime, we use the dimensionless Rouse number $P$ (e.g. Fredsøe and Deigaard, 1992). The Rouse number $P$ is the ratio between the downward motion of the sediment due to gravity and the upward motion due to the water motion:

$$
P=\frac{w_{s}}{\kappa u_{*}}
$$

where $w_{s}$ is the settling velocity of the sediment, $\kappa$ is the von Kármán constant (0.41) and $u_{*}$ is the shear velocity. For the settling velocity of sediment $w_{s}$, we use the relation given by Van Rijn (1993) for a grain size $d$ between 0.1 and $1 \mathrm{~mm}$ :

$$
w_{s}=\frac{10 \nu_{w}}{d}\left(\sqrt{1+\frac{0.01\left(\rho_{s} / \rho_{w}-1\right) g d^{3}}{\nu_{w}^{2}}}\right) .
$$

Here $\nu_{w}$ is the kinematic viscosity coefficient of water, $\rho_{s}$ is the specific density of the sediment, $\rho_{w}$ is the density of water and $g$ is gravitational acceleration. 
The shear velocity $u_{*}$ is defined by

$$
u_{*}=\sqrt{\frac{\tau_{b}}{\rho_{w}}},
$$

where $\tau_{b}$ is the bed shear stress, which is calculated by:

$$
\tau_{b}=\frac{\rho_{w} g U_{M 2}^{2}}{C^{2}},
$$

where $U_{M 2}$ is the amplitude of the horizontal $\mathrm{M}_{2}$-tidal velocity and $C$ is the Chézy roughness coefficient, which is calculated by:

$$
C=18 \log \left(\frac{12 H}{k_{s}}\right),
$$

where $k_{s}$ is the bottom roughness height and $H$ the water depth. Because most sand waves are covered with megaripples (Tobias, 1989; Van Santen et al., 2011), we use the megaripple predictor proposed by Van Rijn (1993) to calculate the bottom roughness height $k_{s}$ :

$$
k_{s}=1.1 \Delta_{s}\left(1-\exp \left(-25 \Delta_{s} / \Gamma_{s}\right)\right),
$$

where $\Delta_{s}$ is the megaripple height and $\Gamma_{s}$ is the megaripple length. Following Van Santen et al. (2011), we take $\Delta_{s}=0.2 \mathrm{~m}$ and $\Gamma_{s}=10 \mathrm{~m}$. The different transport regimes are classified as follows (Fredsøe and Deigaard, 1992):

suspended load transport $(P<1.2)$,

incipient suspended load transport $(1.2<P<2.5)$,

bedload transport $(P>2.5)$.

We calculate the local Rouse numbers $P$ for the Dutch Continental Shelf, for which we use data provided by Borsje et al. (2009a; Chapter 4) on flow velocity amplitude $U_{M 2}$, mean water depth $H_{0}$ and sediment grain size $d$. The data are provided on a uniform grid of $2 \times 2 \mathrm{~km}$. The locations of sand wave fields on the Dutch Continental Shelf are provided by Hulscher and Van den Brink (2001), based on geological charts by the Dutch Geological Service and sand wave data from Van Alphen and Damoiseaux (1989).

All three transport regimes are present at the Dutch Continental Shelf (Figure 3.1A). However, the sand wave fields are characterized by Rouse numbers $P$ closer to the bedload transport regime and sand waves are hardly found where (incipient) suspended load transport is dominant (Figure 3.1B).

Additionally, we calculated the Rouse number $P$ for 32 locations where sand waves are observed around the world, for which the tidal flow velocity amplitude $U_{M 2}$, mean water depth $H_{0}$ and sediment grain size $d$ are known. From these 32 locations, 23 are in the Dutch part of the North Sea (Van Santen et al., 2011), 7 are in the Belgian part of the North Sea (Cherlet et al., 2007), 1 is in San Francisco Bay in the USA (Sterlini et al., 2009) and 1 is in the Gulf of Cadiz in Spain (Németh et al., 2007). The Rouse numbers $P$ at these locations are between 1.9 and 5.0, which is comparable to the range in Rouse numbers $P$ presented in Figure 3.1B. 
(A) Dutch Continental Shelf

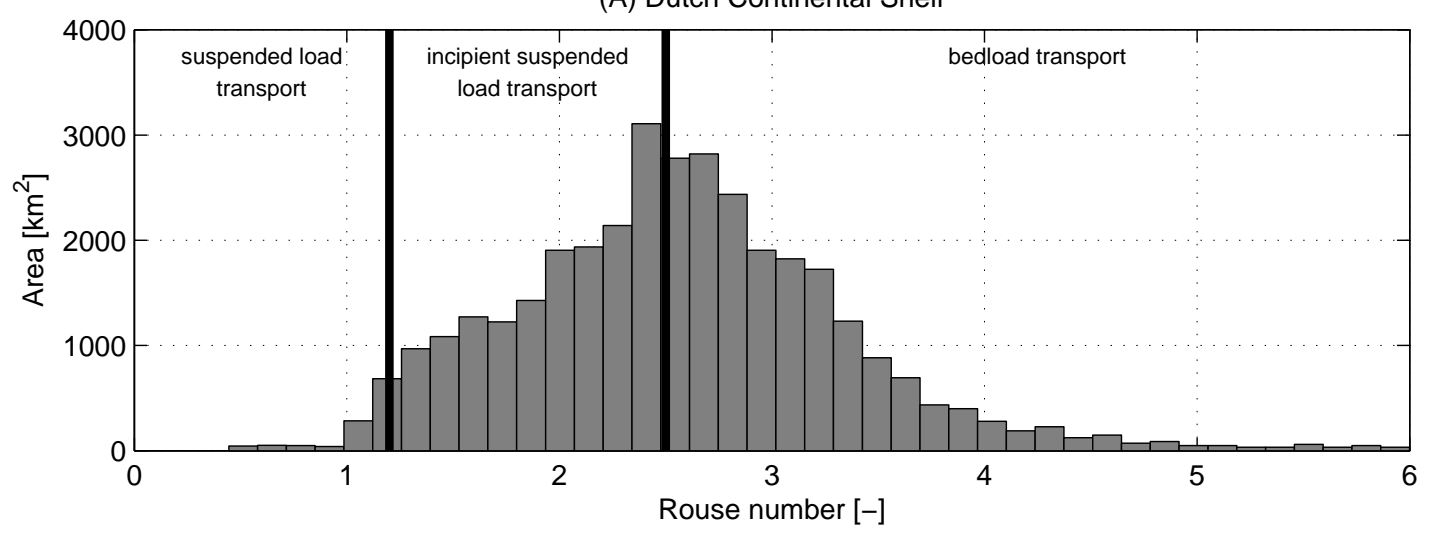

(B) Dutch Continental Shelf covered with sand waves

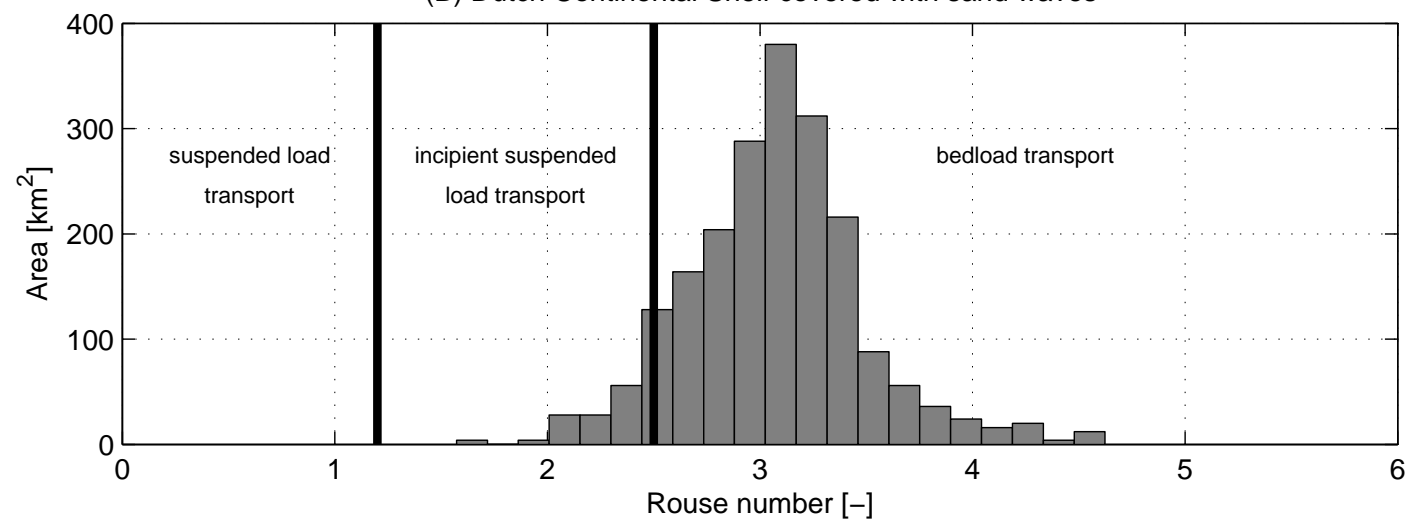

Figure 3.1: Range in Rouse number $P$ for the Dutch Continental Shelf $(\mathrm{A})$ and range in Rouse number $P$ for all sand wave fields observed on the Dutch Continental Shelf (B). Distinction is made between three different transport regimes (Fredsøe and Deigraard, 1992). 


\subsection{Model description}

\subsubsection{Hydrodynamics}

The formation of sand waves is modeled using the numerical shallow water model Delft3D-FLOW (Lesser et al., 2004). The model description is discussed in detail in Borsje et al. (2012a; Chapter 2). In this chapter we only summarize the most important equations and focus on the description of suspended sediment dynamics.

The system of equations consists of horizontal momentum equations, a continuity equation, a turbulence closure model, a sediment transport equation, an advectiondiffusion transport equation and a sediment continuity equation. The vertical momentum equation is reduced to the hydrostatic pressure relation as vertical accelerations are assumed to be small compared to gravitational acceleration. The model equations are solved by applying sigma layering in the vertical. In this study, the model is run in the 2DV mode, i.e. considering flow and variation in $x$ and $z$ direction only, while assuming zero flow and uniformity in $y$ direction and ignoring Coriolis effects. At the length scales of sand waves, Coriolis effects have been shown to have a negligible effect (Hulscher, 1996).

In terms of the $\sigma$-coordinates, the $2 \mathrm{DV}$ hydrostatic shallow water equations are described by:

$$
\begin{gathered}
\frac{\partial u}{\partial t}+u \frac{\partial u}{\partial x}+\frac{\omega}{(H+\zeta)} \frac{\partial u}{\partial \sigma}=-\frac{1}{\rho_{w}} P_{u}+F_{u}+\frac{1}{(H+\zeta)^{2}} \frac{\partial}{\partial \sigma}\left(\nu \frac{\partial u}{\partial \sigma}\right), \\
\frac{\partial \omega}{\partial \sigma}=-\frac{\partial \zeta}{\partial t}-\frac{\partial[(H+\zeta) u])}{\partial x} .
\end{gathered}
$$

Here $u$ is the horizontal velocity, $\omega$ is vertical velocity relative to the moving vertical $\sigma$-plane, $\rho_{w}$ is the water density, $H$ is water depth below reference datum, $\zeta$ is the free surface elevation, $P_{u}$ is the pressure gradient, $F_{u}$ is the horizontal Reynolds stress and $\nu$ is the vertical eddy viscosity. The vertical eddy viscosity $\nu$ is calculated in the $k-\epsilon$ turbulence closure model in which both the turbulent energy $k$ and the dissipation $\epsilon$ are computed (Rodi, 1984). The resulting vertical eddy viscosity $\nu$ is variable both in time and space.

At the bed $(\sigma=-1)$, a quadratic friction law is applied and the vertical velocity $\omega$ is set to zero:

$$
\tau_{b} \equiv \rho_{w} \frac{\nu}{(H+\zeta)} \frac{\partial u}{\partial \sigma}=\rho_{w} u_{*}\left|u_{*}\right|, \omega=0
$$

in which $\tau_{b}$ is the bed shear stress and $u_{*}$ is the shear velocity, that relates the velocity gradient at the bed to the velocity $u$ in the lowest computational grid point by assuming a logarithmic velocity profile (please note the difference between Equation 3.4 and 3.9).

At the free surface $(\sigma=0)$, a no-stress condition is applied and the vertical velocity $\omega$ is set to zero:

$$
\rho_{w} \frac{\nu}{(H+\zeta)} \frac{\partial u}{\partial \sigma}=0, \omega=0
$$




\subsubsection{Sediment transport and bed evolution}

The bedload transport, $S_{b}$ is calculated by (Van Rijn et al., 2004)

$$
S_{b}=0.006 \alpha_{s} \rho_{s} \omega_{s} d M^{0.5} M_{e}^{0.7},
$$

where $\alpha_{s}$ is a correction parameter for the slope effects (see below), $\rho_{s}$ is the specific density of the sediment, $w_{s}$ is the settling velocity of the sediment and $d$ the sediment grain size. $M$ and $M_{e}$ are the sediment mobility number and excess sediment mobility number respectively. Bedload transport is affected by bed level gradients, which makes sediment transported downhill more easily than uphill. Following Bagnold (1956), the correction parameter $\alpha_{s}$ for the slope effect for small-amplitude sand waves is given by:

$$
\alpha_{s}=\lambda_{s},
$$

where $\lambda_{s}$ is the slope parameter which is usually taken inversely proportional to the tangent of the angle of repose of sand (Sekine and Parker, 1992) leading to $\lambda_{s}=2.5$.

The suspended sediment concentration is calculated by solving the advection-diffusion equation:

$$
\frac{\partial c}{\partial t}+\frac{\partial(c u)}{\partial x}+\frac{\partial\left(w-w_{s}\right) c}{\partial z}=\frac{\partial}{\partial x}\left(\epsilon_{s, x} \frac{\partial c}{\partial x}\right)+\frac{\partial}{\partial z}\left(\epsilon_{s, z} \frac{\partial c}{\partial z}\right),
$$

where $c$ is the mass concentration of sediment; $\epsilon_{s, x}$ and $\epsilon_{s, z}$ are the sediment diffusivity coefficients in $x$ and $z$ direction respectively. The horizontal sediment diffusivity $\epsilon_{s, x}$ and vertical sediment diffusivity $\epsilon_{s, z}$ are taken equal to the horizontal and vertical eddy viscosity respectively.

Suspended sediment includes all sediment transported above the reference height, $a=0.01 H$. The reference concentration, $c_{a}$ at height $a$ is given by (van Rijn, 2007):

$$
c_{a}=0.015 \rho_{s} \frac{d T_{a}^{1.5}}{a D_{*}^{0.3}} .
$$

Here $T_{a}$ is the non-dimensional bed shear stress:

$$
T_{a}=\frac{u_{c} \tau_{b}-\tau_{c r}}{\tau_{c r}},
$$

where $u_{c}$ is the efficiency factor, which is the ratio between the grain related friction factor and the total current related friction factor, $\tau_{c r}$ the critical bed shear stress for the initiation of motion of sediment and $D_{*}$ is the non-dimensional particle diameter. Details on the calculation of the efficiency factor, critical bed shear stress and nondimensional particle diameter can be found in Apatsos et al. (2011). At the free surface, the vertical diffusive fluxes are set to zero. Details on the calculation of the suspended sediment concentration profile in the Delft3D model are given by Deltares (2012).

Finally, the bed evolution is governed by the sediment continuity equation (Exner equation), which reads:

$$
\left(1-\epsilon_{p}\right) \frac{\partial z_{b}}{\partial t}+\frac{\partial\left(S_{b}+S_{s}\right)}{\partial x}=0,
$$

in which $\epsilon_{p}=0.4$ is the bed porosity, $S_{b}$ is the bedload transport (Equation 3.11) and $S_{s}$ is the suspended load transport, calculated by: 


$$
\int_{a}^{(H+\zeta)}\left(u c-\epsilon_{s, z} \frac{\partial c}{\partial x}\right) d z .
$$

Equation 3.16 simply states that convergence (or divergence) of the total transport rate must be accompanied by a rise (or fall) of the bed profile.

\subsubsection{Model set-up}

In the horizontal, the model domain is 50 kilometers, with a variable horizontal resolution. In the centre of the model domain the grid size is 10 meters, increasing to a value of $1500 \mathrm{~m}$ at the lateral boundaries. In the vertical, the model grid is composed of 20 layers, with small vertical resolution near the bed and increasing towards the water surface. At the lateral boundaries, a Riemann boundary condition is imposed (Verboom and Slob, 1984). For this type of boundary condition, outgoing waves are allowed to cross the open boundary without being reflected back into the computational domain. The tidal frequency $\sigma_{M 2}$ of the semi-diurnal depth-averaged velocity amplitude $U_{M 2}$ is set at $1.45 \cdot 10^{-4} \mathrm{~s}^{-1}$. The initial bed level perturbation $z_{b}$ is prescribed as the product of a sinusoidal sand wave pattern with a given wavelength $L$ and amplitude $A$ with an envelope function. This ensures a gradual transition from the flat bed towards the sand wave field in the centre of the domain (Figure 3.2). Consequently, a coarser grid can be used near the boundaries.

The Chézy roughness coefficient $C$ is calculated by Equation 3.5. The initial amplitude of the sand wave $A_{0}=0.5 \mathrm{~m}$. Smaller initial amplitudes show the same quantitative behavior, but require more vertical layers to reproduce the near-bed flow characteristics and are consequently more time consuming. The model is run for two tidal cycles. The first tidal cycle is used for spin-up and no bed level changes are allowed. During the second tidal cycle bed level changes are allowed. Assuming exponential growth (which is valid for small-amplitude sand waves (Besio et al., 2008)), the growth rate $\gamma_{R}$ for the bed perturbation is calculated by:

$$
\gamma_{R}=\frac{1}{T} \Re\left[\log \left(\frac{A_{1}}{A_{0}}\right)\right],
$$

where $T$ is the tidal period, $A_{1}$ is the bed amplitude of the sand wave after one tidal cycle of morphodynamic computation. $A_{1}$ is determined by a Fast Fourier Transform (FFT) of the central part of the sand wave domain. Positive values of $\gamma_{R}$ indicate growth of the bottom perturbation, whereas negative values indicate decay.

All values and dimension of the sets of tidal conditions are listed in Table 3.1. The settings for flow velocity amplitude $U_{M 2}$, mean water depth $H_{0}$ and grain size $d$ resemble a typical North Sea situation for sand wave occurrence (Borsje et al., 2009a; Chapter 4). The sets of tidal conditions will be referred to in Section 3.4. 


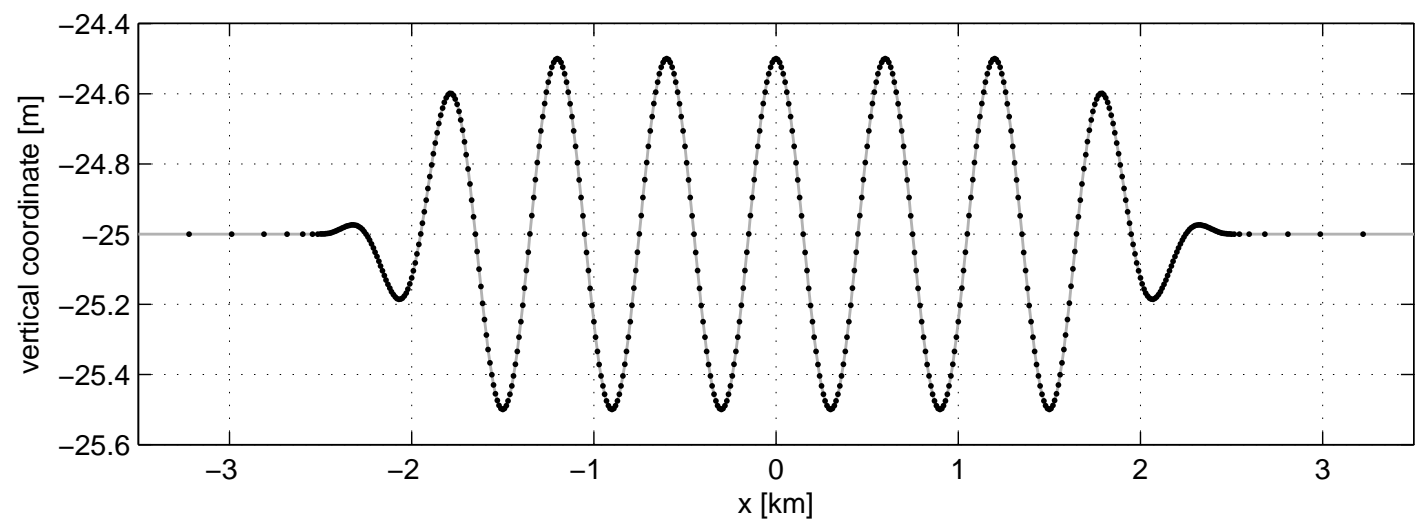

Figure 3.2: Initial bed level for a sand wave field with a wavelength $L=600 \mathrm{~m}$. The crest of the central sand wave is located at $x=0$. The total model domain is $50 \mathrm{~km}$. Horizontal grid points are indicated with dots.

Table 3.1: Overview of the values and dimensions of the model parameters.

\begin{tabular}{llllll}
\hline Description & Symb. & Value(s) & & Dim. \\
\hline Tidal conditions & & I & II & III & \\
\hline Amplitude of & & & & & \\
M $_{2}$-tidal velocity & $\mathrm{U}_{M 2}$ & 0.65 & 0.65 & $0.65-0.8$ & $\mathrm{~m} \mathrm{~s}^{-1}$ \\
Mean water depth & $H_{0}$ & 25 & 25 & 25 & $\mathrm{~m}$ \\
Sediment grain size & $d$ & $0.2,0.35$ & $0.2,0.35$ & $0.25-0.3$ & $\mathrm{~mm}$ \\
Wave number & $k$ & $2 \pi / 600$ & $0.4 \cdot 10^{-3}-0.04$ & $0.4 \cdot 10^{-3}-0.04$ & $\mathrm{~m}^{-1}$ \\
Rouse number & $P$ & $1.4,3.0$ & $1.4,3.0$ & $1.9-2.5$ & - \\
\hline
\end{tabular}


(A) Tide-averaged suspended sediment concentration $\left\langle c>\left[\mathrm{kg} \mathrm{m}^{-3}\right] \mathrm{d}=0.35 \mathrm{~mm}\right.$

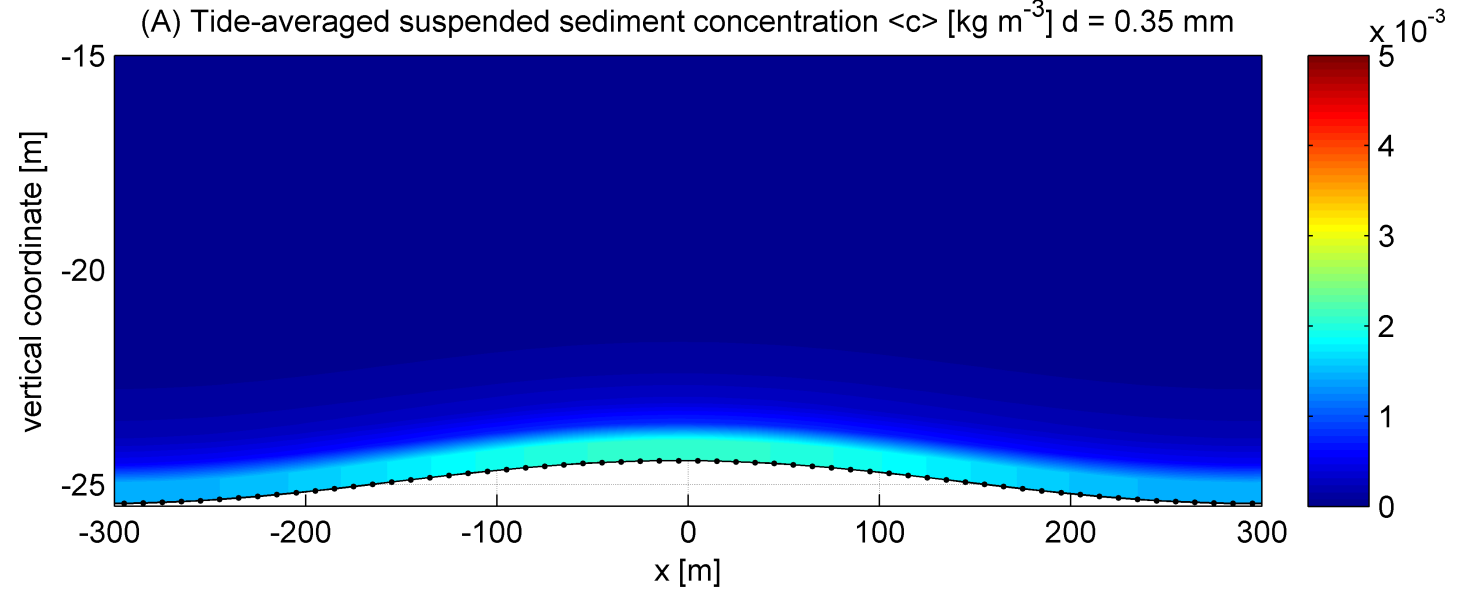

(B) Tide-averaged suspended sediment concentration $\left\langle c>\left[\mathrm{kg} \mathrm{m}^{-3}\right] \mathrm{d}=0.2 \mathrm{~mm}\right.$

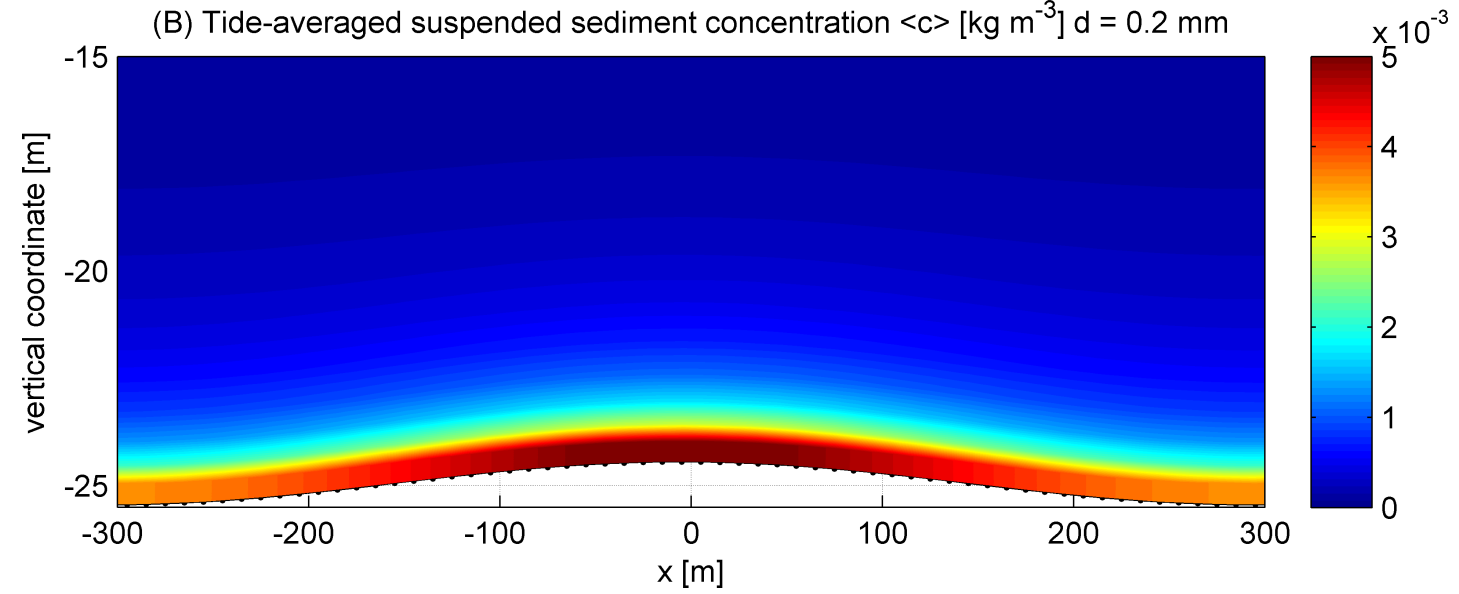

Figure 3.3: Tide-averaged suspended sediment concentrations $\langle c\rangle\left[\mathrm{kg} \mathrm{m}^{-3}\right]$ above a sand wave with wavelength $L=600 \mathrm{~m}$, for a grain size of $d=0.35 \mathrm{~mm}$ (A) and a grain size of $d=0.2 \mathrm{~mm}(\mathrm{~B})$. The sand wave crest is located at $x=0$. For clarity, only the lowest 10 meters of the water column are shown. (Case I in Table 3.1).

\subsection{Results}

\subsubsection{Sediment transport rates}

First, the model is run for two different grain sizes $(d=0.2 \mathrm{~mm}$ and $d=0.35 \mathrm{~mm})$ a flow velocity amplitude $U_{M 2}=0.65 \mathrm{~m} \mathrm{~s}^{-1}$, a mean water depth $H_{0}=25 \mathrm{~m}$ and a sand wave with a wavelength $L=600 \mathrm{~m}$ (Case I in Table 3.1). The values for the mean water depth $H_{0}$, flow velocity amplitude $U_{M 2}$ and wavelength $L$ are identical to those used by Borsje et al. (2012a; Chapter 2). A grain size of $d=0.35 \mathrm{~mm}$ is the average grain size found in sand waves in the North Sea, whereas a grain size of $d=0.2 \mathrm{~mm}$ is smaller than the smallest grain size found in sand waves (Borsje et al., 2009a; Chapter 4).

Focusing on the suspended sediment concentrations, we observe higher tide-averaged suspended sediment concentrations $\langle c\rangle$ above the crest than in the trough (Figure 3.3). This difference can be explained by the slightly higher flow velocities above the crest of the sand wave compared to the trough. Not surprisingly, tide-averaged suspended sediment concentrations $\langle c\rangle$ are higher for smaller grain sizes (Figure 3.3B) 

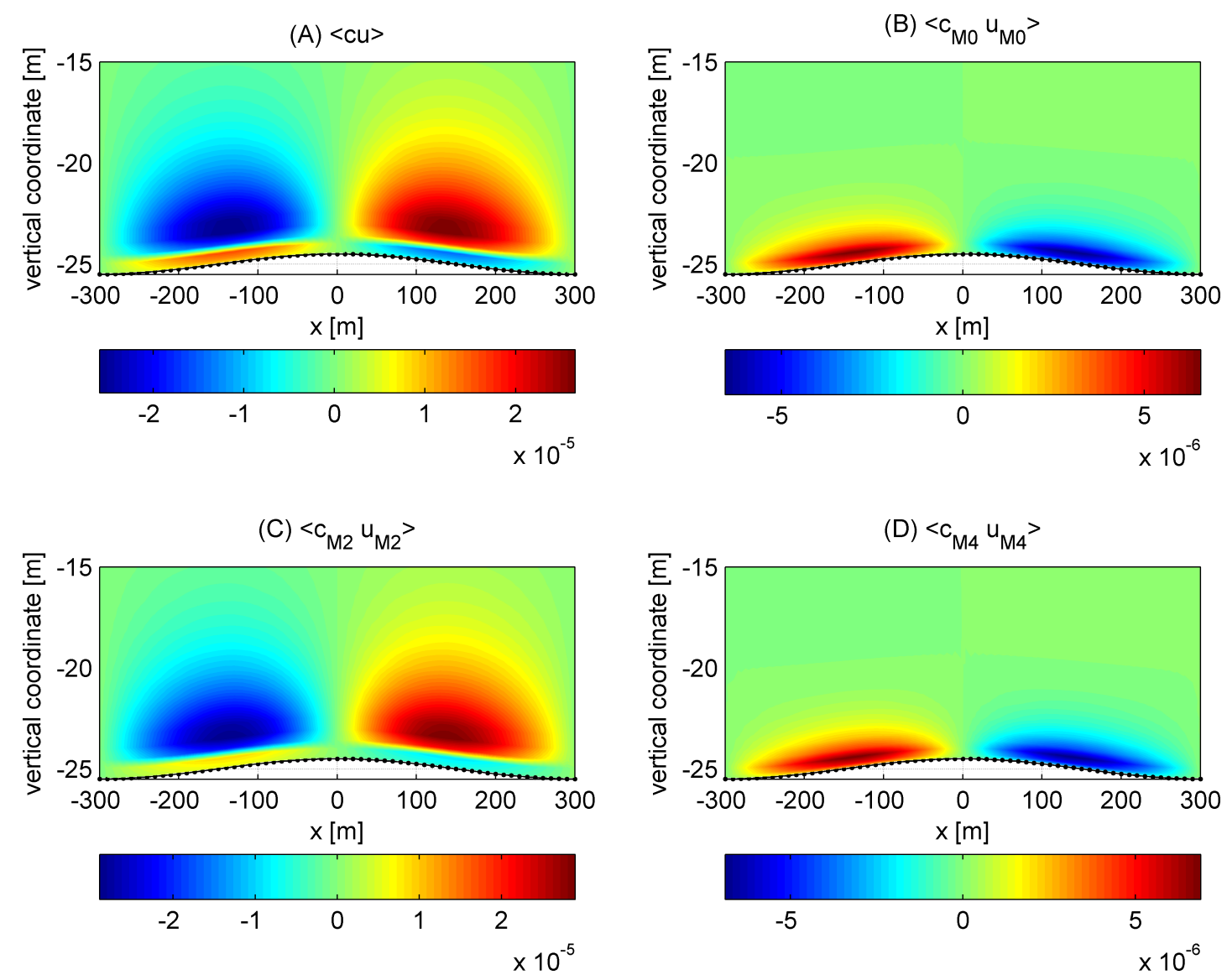

Figure 3.4: Tide-averaged suspended sediment flux $\langle c u\rangle\left[\mathrm{kg} \mathrm{s}^{-1} \mathrm{~m}^{-2}\right]$ above a sand wave with wavelength $L=600 \mathrm{~m}(\mathrm{~A})$, and the separate contributions to it from the mean $\left\langle c_{M 0} u_{M 0}>\right.$ (B), first $\left\langle c_{M 2} u_{M 2}>\right.$ (C) and second $\left\langle c_{M 4} u_{M 4}>\right.$ (D) harmonic components of concentration $c$ and horizontal velocity $u$. Grain size $d=0.2 \mathrm{~mm}$. For clarity, only the lowest 10 meters of the water column are shown. (Case I in Table 3.1).

compared to larger grain sizes (Figure 3.3A). Sediment concentration maxima occur near the bed, and decrease rapidly higher in the water column. At 1 meter above the crest, the tide-averaged suspended sediment concentrations $\langle c\rangle$ are already $38 \%$ and $55 \%$ of the tide-averaged reference concentration $\left\langle c_{a}\right\rangle$, for grain sizes of $d=0.35$ $\mathrm{mm}$ and $d=0.2 \mathrm{~mm}$ respectively.

For small grain sizes, the tide-averaged bedload transport rate $\left\langle S_{b}\right\rangle$ is smaller than for large grain sizes (Figure 3.5A). However, the total load is much larger for small grain sizes. Remarkably, the tide-averaged suspended load transport rate $\left\langle S_{s}\right\rangle$ (Figure 3.5B) is opposite in sign compared to the tide-averaged bedload transport rate $\left.<S_{b}\right\rangle$ (Figure 3.5A). Since the divergence or convergence in transport rates determines the growth or decay of the sand wave (Equation 3.16), both transport mechanisms induce an opposite effect on sand wave formation. The bedload transport induces sand wave growth and suspended load transport provides a damping effect. For small grain sizes $(d=0.2 \mathrm{~mm})$ the magnitude of the tide-averaged suspended load transport $\left\langle S_{s}\right\rangle$ is even larger than the magnitude of the tide-averaged bedload transport rate $<S_{b}>$, inducing a decay of the sand wave for this wavelength and tidal condition. Tide-averaged bedload transport rates $\left\langle S_{b}\right\rangle$ are much less sensitive to grain size 
variation compared to tide-averaged suspended load transport rates $\left\langle S_{s}>\right.$ (Figure $3.5)$.

The damping effect of suspended load transport on sand wave formation originates from slight differences in sediment concentration between both halves of the tidal cycle. Both during positive and negative flow, the absolute horizontal velocities $u$ and the sediment concentrations $c$ are higher above the crest of the sand wave compared to the trough. As a consequence, during the downhill motion (from the crest to the trough) the suspended load transport rate is larger at the flank of a sand wave compared to the uphill motion (from the trough to the crest). Figure 3.4 shows the various contributions to the tide-averaged suspended load transport rate $\langle c u\rangle$. Just as for bedload transport, the mean flow $\left\langle c_{M 0} u_{M 0}\right\rangle$ (Figure 3.4B) induces a convergence of suspended load transport at the sand wave crest and hence growth of the sand wave. However, the tide-averaged suspended load transport $\langle c u\rangle$ (Figure 3.4A) is clearly dominated by the flattening contribution from velocity and concentration fluctuations with the frequency of the tide $\left\langle c_{M 2} u_{M 2}>\right.$ (Figure $3.4 \mathrm{C}$ ).
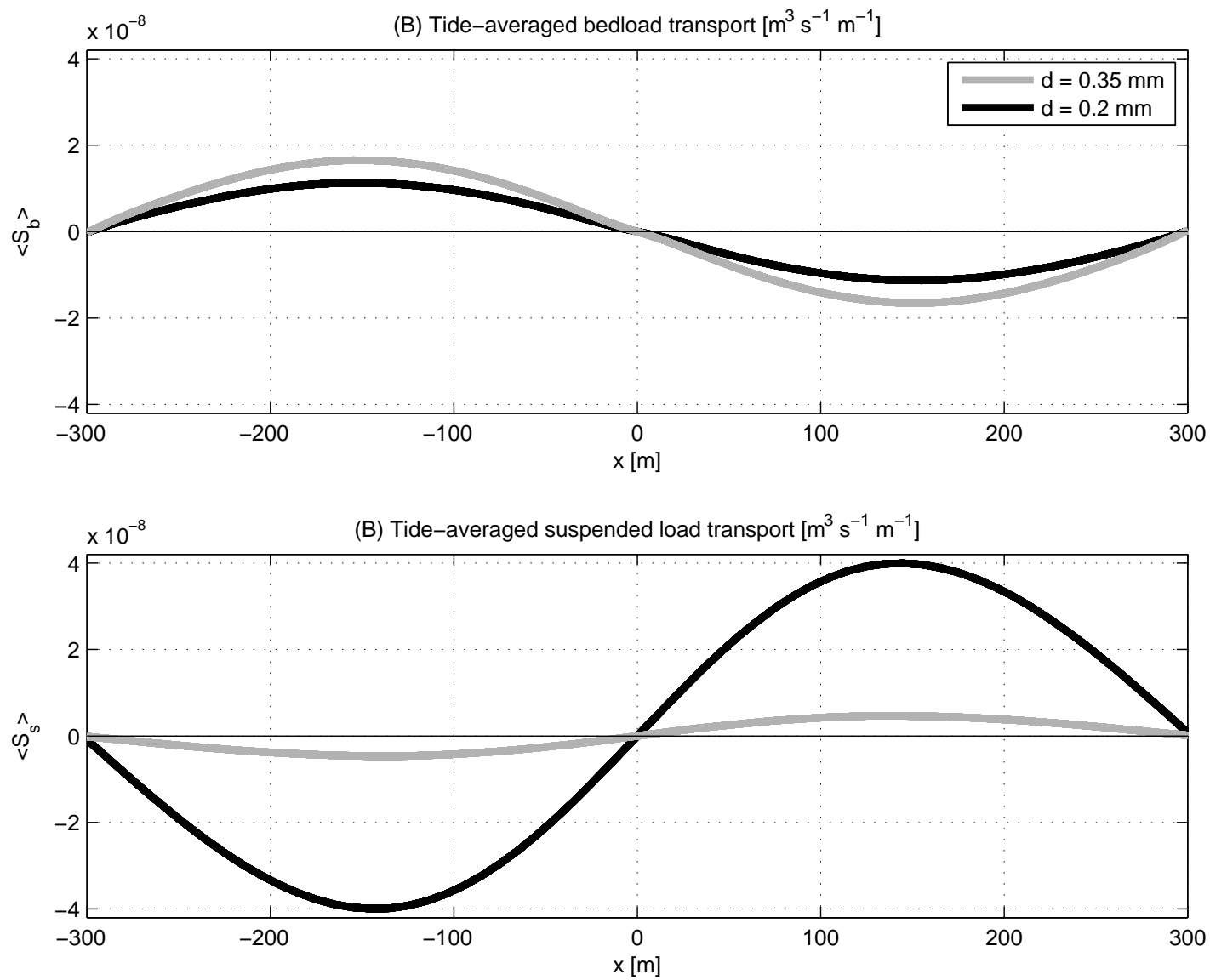

Figure 3.5: Tide-averaged transport rates $\left[\mathrm{m}^{3} \mathrm{~s}^{-1} \mathrm{~m}^{-1}\right]$ over a sand wave with wavelength $L=600 \mathrm{~m}$, for the bedload transport $<S b>$ (including slope-induced transport) (A) and the suspended load transport $\langle S s\rangle$ (B), for a grain size of $d=$ $0.35 \mathrm{~mm}$ (gray line) and $d=0.2 \mathrm{~mm}$ (black line). (Case I in Table 3.1). 

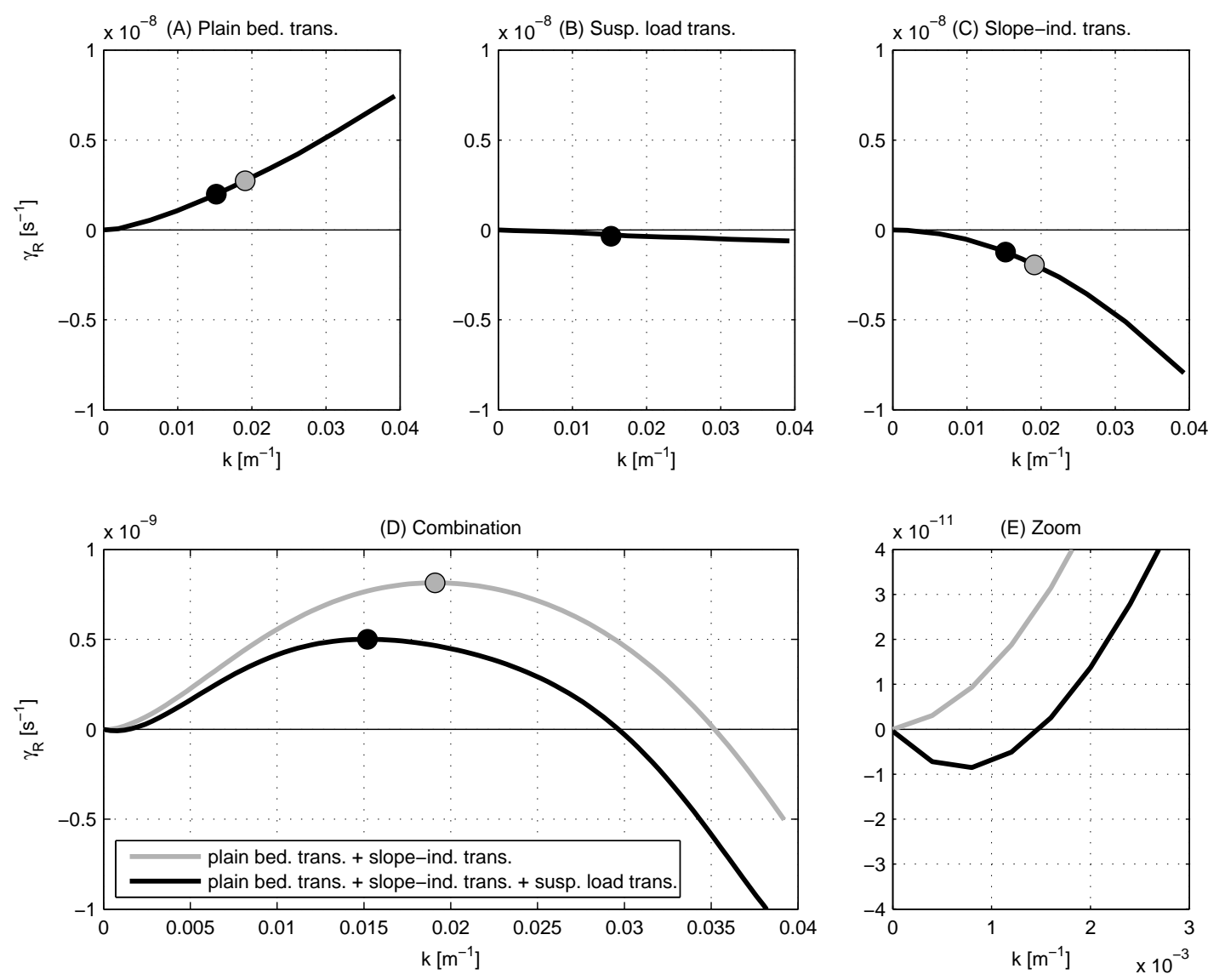

Figure 3.6: The total growth rate curve (D) is the sum of the plain bedload transport component (A), the suspended load transport component (B) and the slope-induced transport component $(\mathrm{C})$ for a grain size of $d=0.35 \mathrm{~mm}$. On the horizontal axis the wave number $k\left[\mathrm{~m}^{-1}\right]$ is given and on the vertical axis the growth rate $\gamma_{R}\left[\mathrm{~s}^{-1}\right]$. The circles indicate the growth rates belonging to the fastest growing mode $L_{F G M}$. Distinction is made between the growth curve for a combination of the plain bedload transport component and slope-induced transport component (gray line) and a combination for the plain bedload transport component, suspended load transport component and slope-induced transport component (black line). A zoom of the total growth curve is given in (E) for small wave numbers $k$. (Case II in Table 3.1).

\subsubsection{Bed evolution}

Next, we study the damping effect of suspended load transport on the growth curve by varying the topographic wave number $k=2 \pi / L$ for two grain sizes, while keeping the flow velocity amplitude $U_{M 2}$ and mean water depth $H_{0}$ constant (Case II in Table 3.1). The damping effect of suspended load transport is the strongest for the largest wave numbers (Figure 3.6B and 3.7B). For a grain size of $d=0.35 \mathrm{~mm}$ the contribution of the suspended load transport to the total growth rate is relatively small (compared to the plain bedload transport and the slope-induced transport). However, for a grain size of $d=0.2 \mathrm{~mm}$, the contribution of suspended load transport is in the same order of magnitude as the plain bedload transport and the slope-induced transport (Figure 3.6). The fastest growing mode is slightly influenced for relatively coarse grains. The 

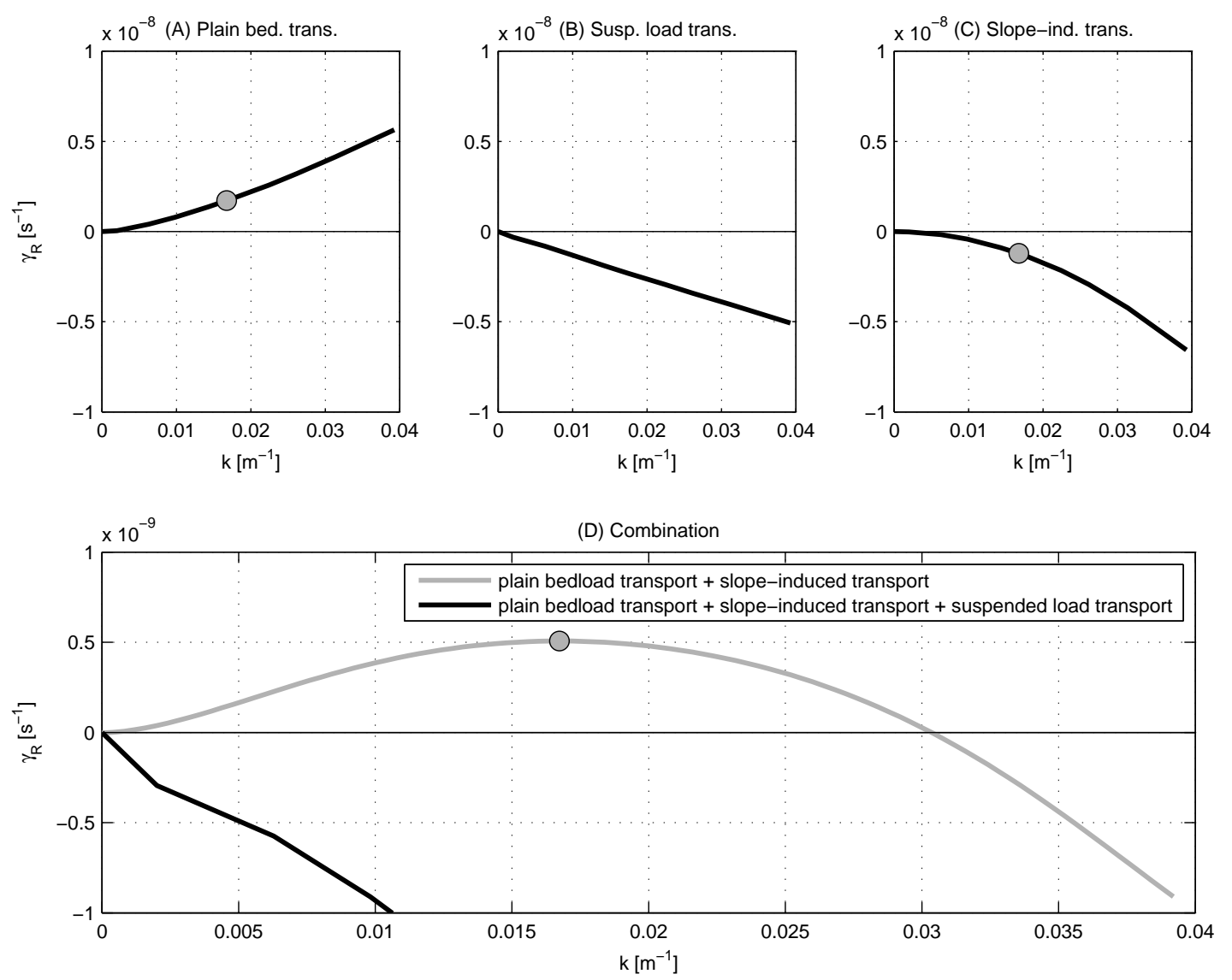

Figure 3.7: The total growth rate curve (D) is the sum of the plain bedload transport component (A), the suspended load transport component (B) and the slope-induced transport component $(\mathrm{C})$ for a grain size of $d=0.2 \mathrm{~mm}$. On the horizontal axis the wave number $\mathrm{k}\left[\mathrm{m}^{-1}\right]$ is given and on the vertical axis the growth rate $\gamma_{R}\left[\mathrm{~s}^{-1}\right]$. The circles indicate the growth rates belonging to the fastest growing mode $L_{F G M}$. Distinction is made between the growth curve for a combination of the plain bedload transport component and slope-induced transport component (gray line) and a combination for the plain bedload transport component, suspended load transport component and slopeinduced transport component (black line). (Case II in Table 3.1).

fastest growing mode increases from $L_{F G M}=330 \mathrm{~m}$ to $L_{F G M}=400 \mathrm{~m}$ by including suspended sediment (Figure 3.6). For relatively small grains all bottom perturbations are damped and sand waves are absent due to the inclusion of suspended sediment dynamics. However, without considering suspended sediment a fastest growing mode of $L_{F G M}=370 \mathrm{~m}$ is found (Figure 3.7).

Another interesting observation is the damping of long sand waves for a relative large grain size (Figure 3.6E). Whereas the slope-induced transport suppresses very short sand waves, suspended sediment dynamics causes very long sand waves to decay. For this tidal condition we find positive growth rates for sand waves with a wavelengths between $L=200 \mathrm{~m}$ and $L=4200 \mathrm{~m}$. 


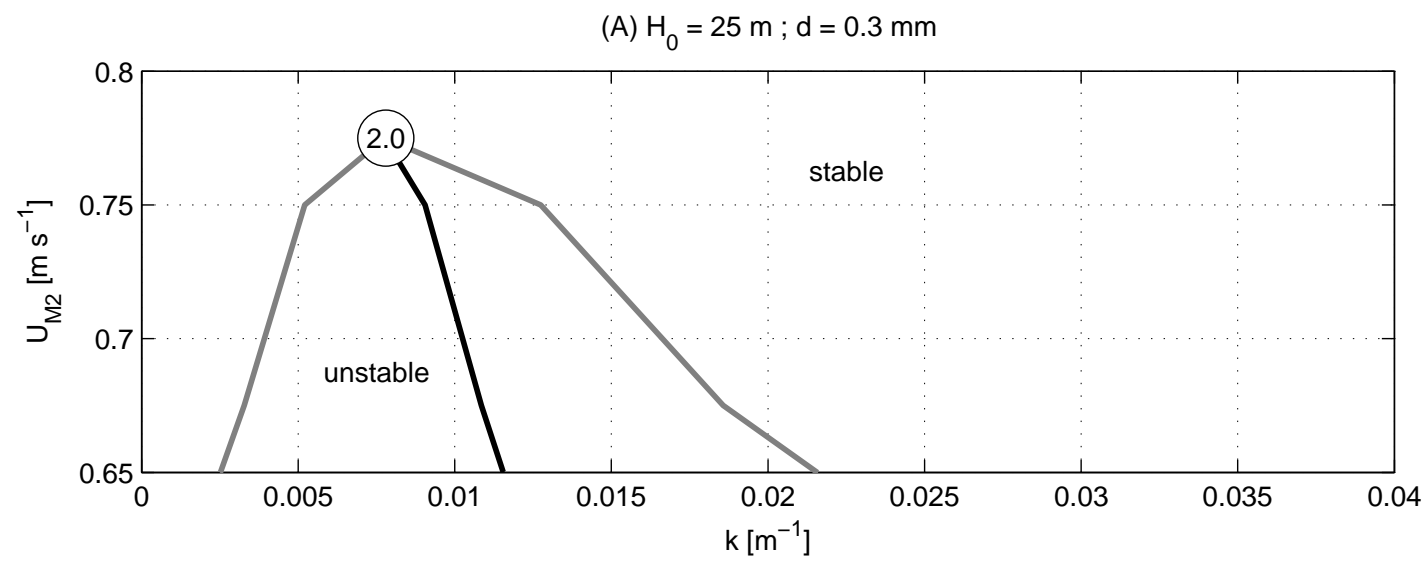

(B) $U_{M 2}=0.65 \mathrm{~m} \mathrm{~s}^{-1} ; \mathrm{H}_{0}=25 \mathrm{~m}$

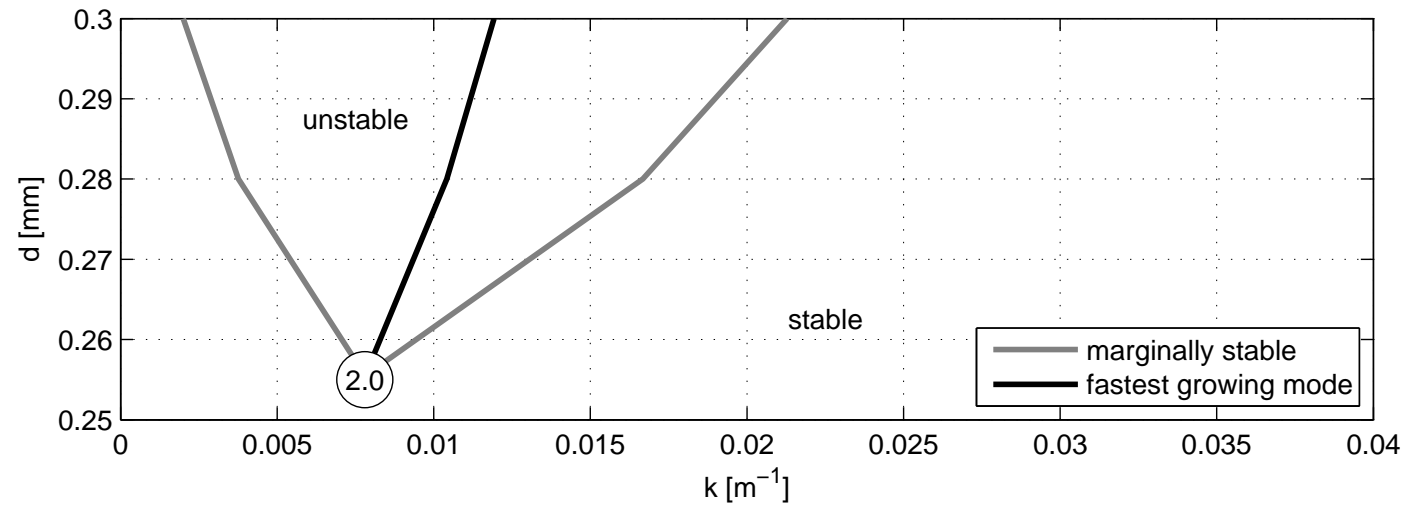

Figure 3.8: Marginal stability condition (gray line), which discriminates between positive growth rates (unstable) and negative growth rates (stable) as function of the wave number $k\left[\mathrm{~m}^{-1}\right]$ for a variation in flow velocity amplitude $U_{M 2}\left[\mathrm{~m} \mathrm{~s}^{-1}\right](\mathrm{A})$ and grain size $d[\mathrm{~mm}](\mathrm{B})$, while keeping the other parameters equal to the settings given in the title of the two subplots. The growth rate with the fastest growing mode is indicated with the black line. The Rouse number $P$ for the marginal stable condition is indicated in the circle. (Case III in Table 3.1).

\subsubsection{Critical conditions for sand wave generation}

The model results show negative growth rates for both long sand waves and short sand waves (Figure 3.6). This motivates us to investigate whether we can find critical conditions for sand waves formation. We start with a simulation for which the Rouse number $P=2.5$ (lower limit of bedload transport regime: Figure 3.1) and vary successively the flow velocity amplitude $U_{M 2}$ and grain size $d$ towards the suspended load transport regime according to the parameter range given in Table 3.1 (Case III). The parameter settings for the reference run (for which the Rouse number $P=2.5$ ) is as follows: flow velocity amplitude $U_{M 2}=0.65 \mathrm{~m} \mathrm{~s}^{-1}$, mean water depth $H_{0}=25 \mathrm{~m}$ and grain size $d$ $=0.3 \mathrm{~mm}$. The Rouse number $P$ is hardly dependent on the mean water depth $H_{0}$, which is therefore taken constant in this analysis.

For the reference run, the fastest growing mode $L_{F G M}=540 \mathrm{~m}$ and sand waves with a wavelength between $L=2500 \mathrm{~m}$ and $L=290 \mathrm{~m}$ show positive growth rates (Figure 3.8). By increasing the flow velocity amplitude $U_{M 2}$ the fastest growing mode 
$L_{F G M}$ increases. The situation for which sand waves are marginally generated is for a flow velocity amplitude $U_{M 2}=0.775 \mathrm{~m} \mathrm{~s}^{-1}$ and a corresponding Rouse number $P=2.0$ (Figure 3.8A). For higher flow velocity amplitudes, all bed perturbations are damped and the flat bed is stable. Next, we decrease the grain size $d$ (Figure 3.8B). Marginally generated sand waves are observed for a Rouse number $P=2.0$. The critical grain size $d=0.255 \mathrm{~mm}$ for the given tidal forcing.

\subsection{Discussion}

In this chapter we study the relation between suspended load transport and the occurrence of sand waves, both in the field and in a numerical shallow water model (Delft3D). In the field, sand waves are only observed in regions where bedload is the dominant transport mode. Where suspended load becomes the dominant transport mode, sand waves are not found. The same relation is found in model simulations in which the effect of suspended load transport on sand wave formation and occurrence is studied. We found critical conditions for sand wave occurrence by using an advanced $k-\epsilon$ turbulence model with the inclusion of suspended sediment dynamics. A combination of an advanced turbulence model with suspended sediment dynamics has never been applied before in sand wave modeling. Nevertheless, critical conditions for sand wave generation were presented earlier by Komarova and Hulscher (2000), who employed a linear stability analysis on an idealized sand wave model in which only bedload transport was included. They used the slope parameter to control the unstable modes and found a critical mode of $L_{c r i t}=571 \mathrm{~m}$ for a mean water depth $H_{0}=45 \mathrm{~m}$ and for a critical slope parameter $\lambda_{s}=21$. They used a turbulence model (in which viscosity is mean water depth times near-bed velocity) where the time-dependency was crucial to find the critical conditions. This is in line with our result, that the advanced $k-\epsilon$ turbulence model with the inclusion of suspended sediment dynamics is able to generate the critical conditions whereas the constant viscosity is not able to do so. However, in our analysis we find critical conditions for more realistic parameter settings. Such a result was not presented in idealized models including suspended sediment (Blondeaux and Vittori 2005ab; Besio et al., 2006).

The model results hardly depend on the choice of roughness predictor. In our model, the Chézy roughness coefficient $C$ is a function of the local water depth $H$ and roughness height $k_{s}$ (Equation 3.5). Following Van Rijn (1993), the roughness height $k_{s}$ of the megaripples on top of the sand waves is spatially uniform (Equation 3.6). In other roughness predictors, also the effect of grain size $d$ on the roughness height is taken into account (e.g. Soulsby and Whitehouse (2005) as applied by Besio et al. (2006)). By applying the roughness predictor by Soulsby and Whitehouse (2005) for the tidal conditions we used (Table 3.1), the roughness height $k_{s}$ shows a variation of $36 \%$, which results in a variation of $3 \%$ in Chézy roughness coefficient $C$, and the model results hardly changed by using the roughness predictor by Soulsby and Whitehouse (2005) instead of using the roughness predictor by Van Rijn (1993). Moreover, by applying the roughness predictor by Soulsby and Whitehouse (2005) in the field data analysis (Section 3.2), a Rouse number $P=2.1$ indicates the lower limit of sand wave occurrence, a value which is comparable to the value of $P=2.0$ found by using the roughness predictor by Van Rijn (1993). 


\subsection{Conclusions}

Analysis of field data on sand wave occurrence showed that sand waves are only found where bedload transport is the dominant transport mode. Where suspended load transport is the dominant transport regime, sand waves are absent. The lower limit of sand wave occurrence in the field is found at a Rouse number $P=1.9$.

Model simulations with the numerical shallow water model Delft3D showed that the damping effect of suspended load transport is caused by the advection of suspended sediment, resulting in a tide-averaged divergence in suspended load transport at the sand wave crest and hence sand wave decay. For relatively large grain sizes $(d=0.35$ $\mathrm{mm}$ ) the preferred wavelength of the sand wave was hardly influenced by including suspended sediment, due to the small suspended sediment concentrations. However, for a relatively small grain size $(d=0.2 \mathrm{~mm})$, the damping effect of suspended load transport in combination with slope-induced transport dominated over the growth mechanism due to bedload transport leading to a stable flat bed.

Idealized models in which suspended sediment dynamics were included showed a positive growth rate for long sand waves. Alternatively, model simulations in this chapter showed that suspended load transport in combination with an advanced turbulence model caused very long sand waves to damp, resulting in a finite range of wavelengths of sand waves that experience growth. Based on this result, critical conditions for sand wave occurrence were found in the model by varying the flow velocity amplitude and grain size independently. The simulations showed that sand waves were only formed for Rouse numbers $\mathrm{P}>2.0$, a value which is comparable to the field observations. 


\title{
Chapter 4
}

\section{Modeling biogeomorphological influences for offshore sand waves}

This chapter has been published as:

B.W. Borsje, M.B. de Vries, T.J. Bouma, G. Besio, S.J.M.H. Hulscher, P.M.J. Herman, 2009. Modeling bio-geomorphological influences for offshore sand waves. Continental Shelf Research 29, 1289-1301. doi: 10.1016/j.csr.2009.02.008.

\begin{abstract}
The coastal environment shows a wide range of bed patterns, for which sand waves and sandbanks are among the most common. Less known in this context is the high benthic diversity in the coastal environment, which gives rise to the question to what extent the benthos interacts with the shape of the seabed. This paper reviews field and flume experiments on biogeomorphological influences between benthos and sediment and tests the hypothesis that both the occurrence and the dimensions of sand waves are dependent on the benthic diversity in the North Sea. Mathematical inclusions to account for biological activity in idealized models reveal that biota is able to influence the wave length of sand waves significantly, compared to the default case. More importantly, the models indicate that biota is able to induce bed patterns under conditions when the physical parameters suggest a stable flat bed and vice versa. Present model explorations indicate that future research should focus on the parameterization of subtidal biological activity on sediment dynamics and thereby on seabed patterns. Such knowledge will enable process based modeling of the spatial and temporal variation in biological activity on seabed morphodynamics and validate the proposed modeling approach with field measurements.
\end{abstract}




\subsection{Introduction}

Coastal areas are highly important both from an ecological and economical perspective, as these areas serve both for a broad variety of human activities and form the habitat for a broad variety of organisms. Many human activities such as offshore constructions, maintaining navigation channels and constructing pipelines and telecommunication cables depend on a good understanding of sediment dynamics in coastal waters (Németh et al., 2003). The conservation and management of the benthic biodiversity in the coastal zone also requires knowledge about spatial and temporal distribution of macrobenthic species and thus the sediment dynamics (Borja et al., 2000). Hence there is both from an ecological and economical perspective a growing interest in the biophysical interactions between benthos and their sedimentary environment. Studies from intertidal areas indicate that benthos can strongly influence local sediment composition and dynamics, by acting as either stabilizers or destabilizers (e.g. Widdows and Brinsley, 2002). The subtidal seabed is neither flat nor static, and significant differences can be found in the benthic assemblage related to meso-scale bedforms at the subtidal seabed (e.g. Baptist et al., 2006). Nevertheless, the feedback effects from these assemblages to the characteristics of the subtidal bedforms have not yet been studied.

Nowadays, idealized models are often used to predict seabed dynamics (for an overview see Besio et al., 2008). However, the hydrodynamics and sediment dynamics in these models lack correction for biological activity. Given the predictive power of the idealized models, extending the models with biological activity will give us a tool to better manage the utilization and conservation of the seabed.

The aim of this paper is (1) to explore the influences of biota on bedforms in a subtidal environment and (2) to propose formulations to include biogeomorphological influences in idealized models. We will achieve these objectives by reviewing the offshore environment both from a morphodynamic and biological perspective (Section 4.2) and from the known impact of some key benthic species in the subtidal environment on the hydrodynamics and sediment dynamics (Section 4.3). We subsequently focus on methods to model such biogeomorphological influences between key benthic species and hydrodynamics plus sediment dynamics (Section 4.4). Next, the main findings of this chapter are discussed (Section 4.5), leading to important general conclusions (Section 4.6). In the present chapter we use the Dutch part of the North Sea as an example, as it has been relatively well described with respect to bedforms and organisms (details in the next Sections).

\subsection{Offshore environment of the Dutch Coast}

The Dutch part of the North Sea covers roughly $57000 \mathrm{~km}^{2}$ with a maximum water depth of $70 \mathrm{~m}$ (Figure 4.1A). Several bed forms are present on the offshore seabed (Figure 4.1B), distinguishable by their wave length, height, orientation with respect to the tidal current and their capability to migrate. Sandbanks (Figure 4.1C) have wave lengths (distance between two crests) of a few kilometers and amplitudes of tens of meters. The orientation of the crests with respect to the principal direction of the tidal current is up to $40^{\circ}$ anticlockwise in the Northern Hemisphere. There is no evidence that sandbanks move (Dyer and Huntley, 1999). Sand waves (Figure 4.1D) have much smaller wave lengths (of the order of hundreds of meters), while the heights are up to 5 $\mathrm{m}$. Sand waves migrate with a speed of tens of meters per year (McCave, 1971). Their 
orientation is almost perpendicular to the direction of the main current. Sandbanks are associated with relatively weak tidal currents, whereas sand waves are related to strong tidal currents. As a result, sandbank and sand wave fields sometimes partly overlap.

The sandbanks and sand waves occurring in the Dutch part of the North Sea differ in location (top panel Figure 4.2, after Hulscher and van den Brink, 2001), and together cover approximately $42 \%$ of the Dutch part of the North Sea. Combining the locations with maps showing the spatial distribution of physical properties like mud content (defined as the weight of the mud fraction divided by the weight of the total sample), median grain size, slope, current velocity and water depth (Figure 4.3), it can be seen that the sandbanks and sand waves clearly differ in some of their physical characteristics (Figure 4.2 bottom panel). Not surprisingly, the spatial analysis clearly shows that sand waves do not occur in muddy environments.

The bottom of the North Sea is inhabited by a great number of benthic organisms that live in and on the bottom of the sea (Heip et al., 1992, Künitzer et al., 1992, Rabaut et al., 2007). By their activities these benthic organisms can modify their

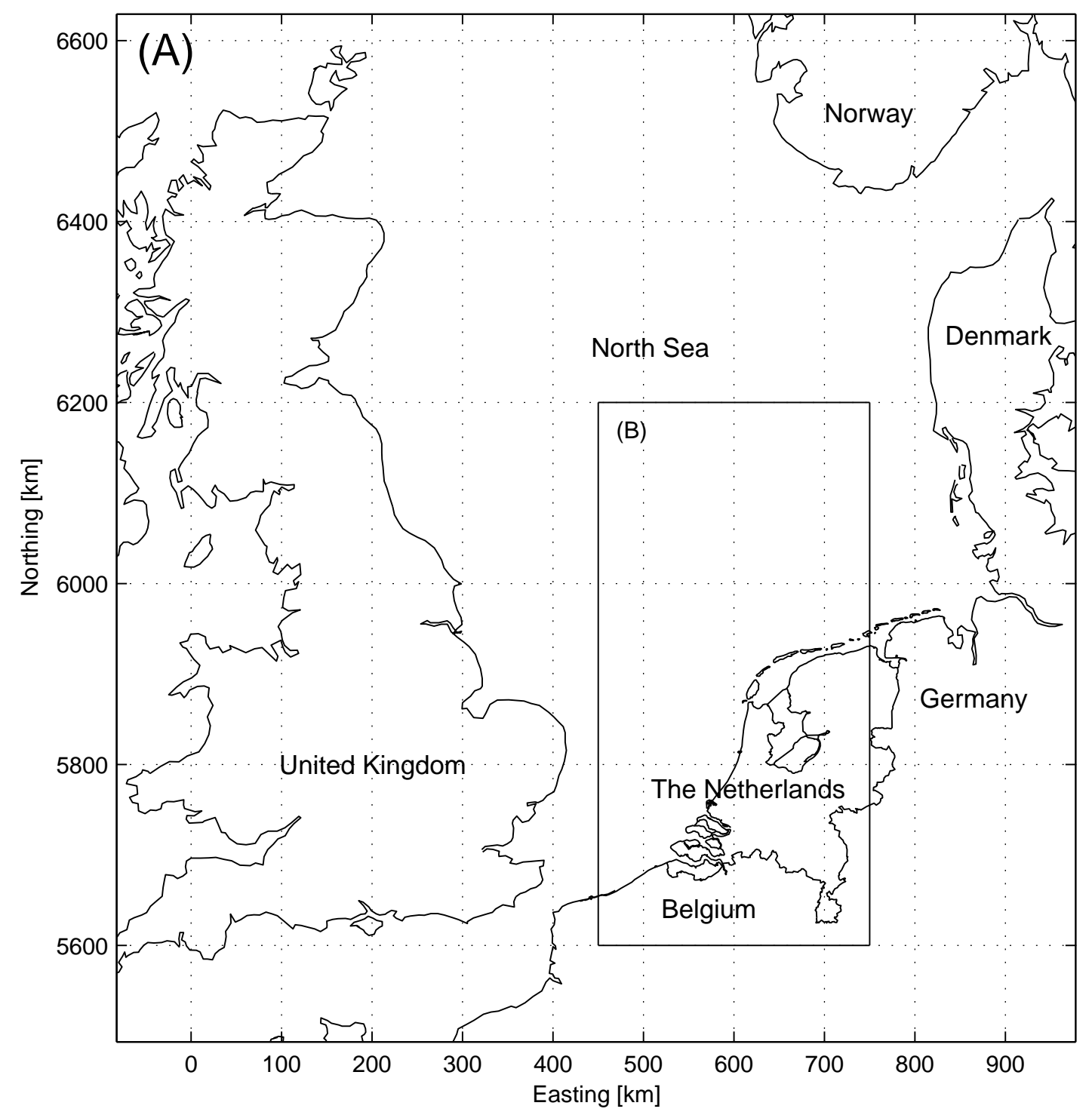



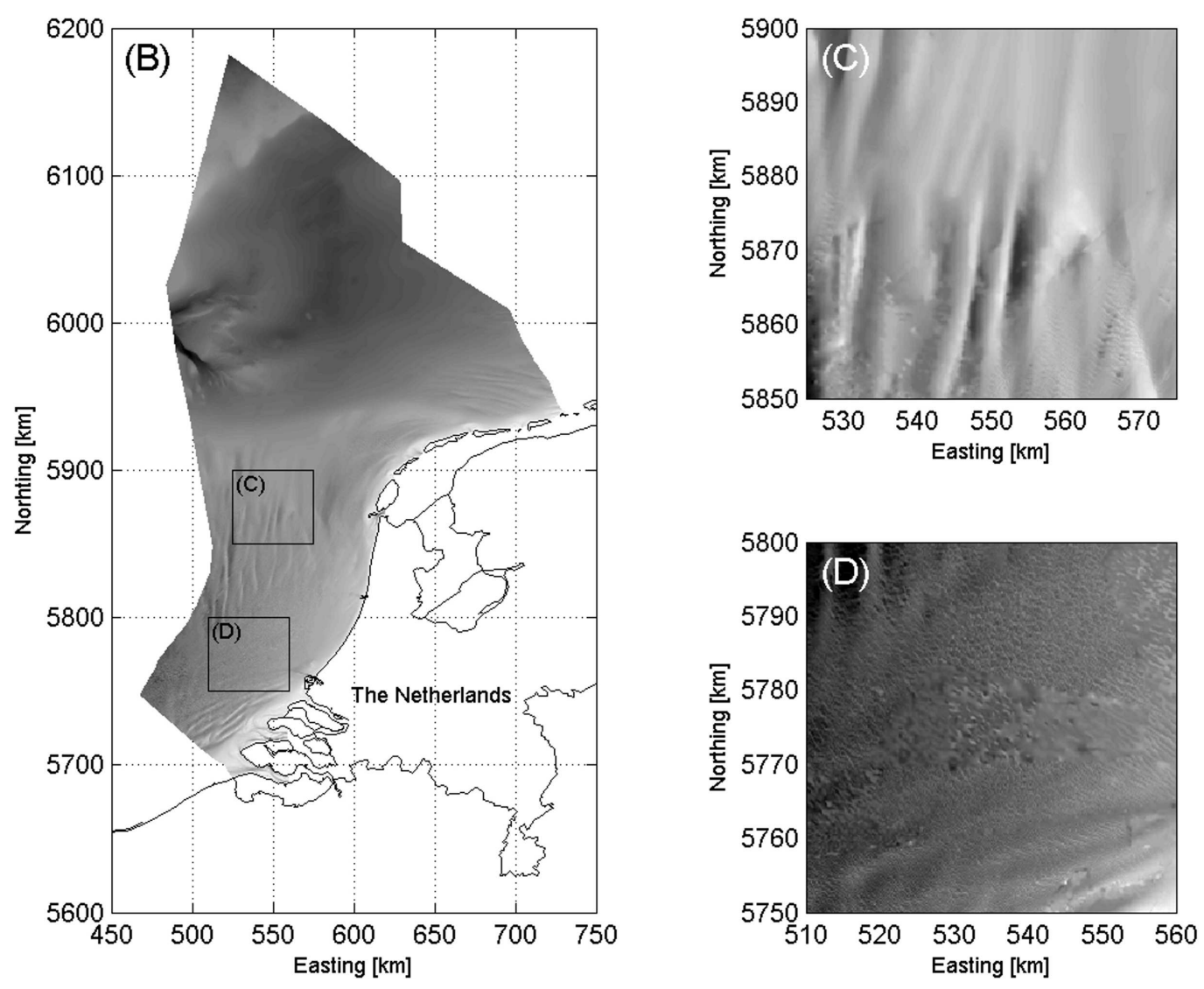

Figure 4.1: Seabed patterns in the Dutch part of the North Sea ((A: previous page) and (B)), in which sandbanks (C) and sand wave fields (D) can be distinguished. Gridsize is $200 \times 200 \mathrm{~m}$.

habitat, which is generally referred to as biogeomorphological influence. The benthic community's composition on the seabed is generally related to physical parameters like median grain size, slope, mud content and water depth. Consequently, we only focus on benthos existing in the parameter range presented in Figure 4.2.

In the present chapter, we focus on three species that are (1) characteristic for benthos living in sand waves and sandbanks in the North Sea, (2) can be found in large amounts in and on the bed and (3) have significant influences on the surrounding environment. The first one is the sea urchin Echinocardium cordatum (Mortensen, 1927), which is usually 40-50 $\mathrm{mm}$ in length, has a density distribution of around 20 individuals per $\mathrm{m}^{2}$ and lives up to $200 \mathrm{~mm}$ deep into the sediment. The second species is the tube-building worm Lanice conchilega (Holthe, 1986). The worm can reach a length up to $150 \mathrm{~mm}$, partly protruding from the sediment, and its density distribution is locally extremely large (over 3000 individuals $\mathrm{m}^{-2}$ ). Finally, the third species we study is the clam Tellina fabula (Tebble, 1966), which has a maximum shell length of $20 \mathrm{~mm}$, a slightly smaller density distribution compared to E. cordatum of around 15 individuals per $\mathrm{m}^{2}$ and lives up to $100 \mathrm{~mm}$ deep in the sediment.

The influence of these three species on the sediment dynamics and hydrodynamics will be compared to the default case, which is defined as the situation in which no biological activity is present. 

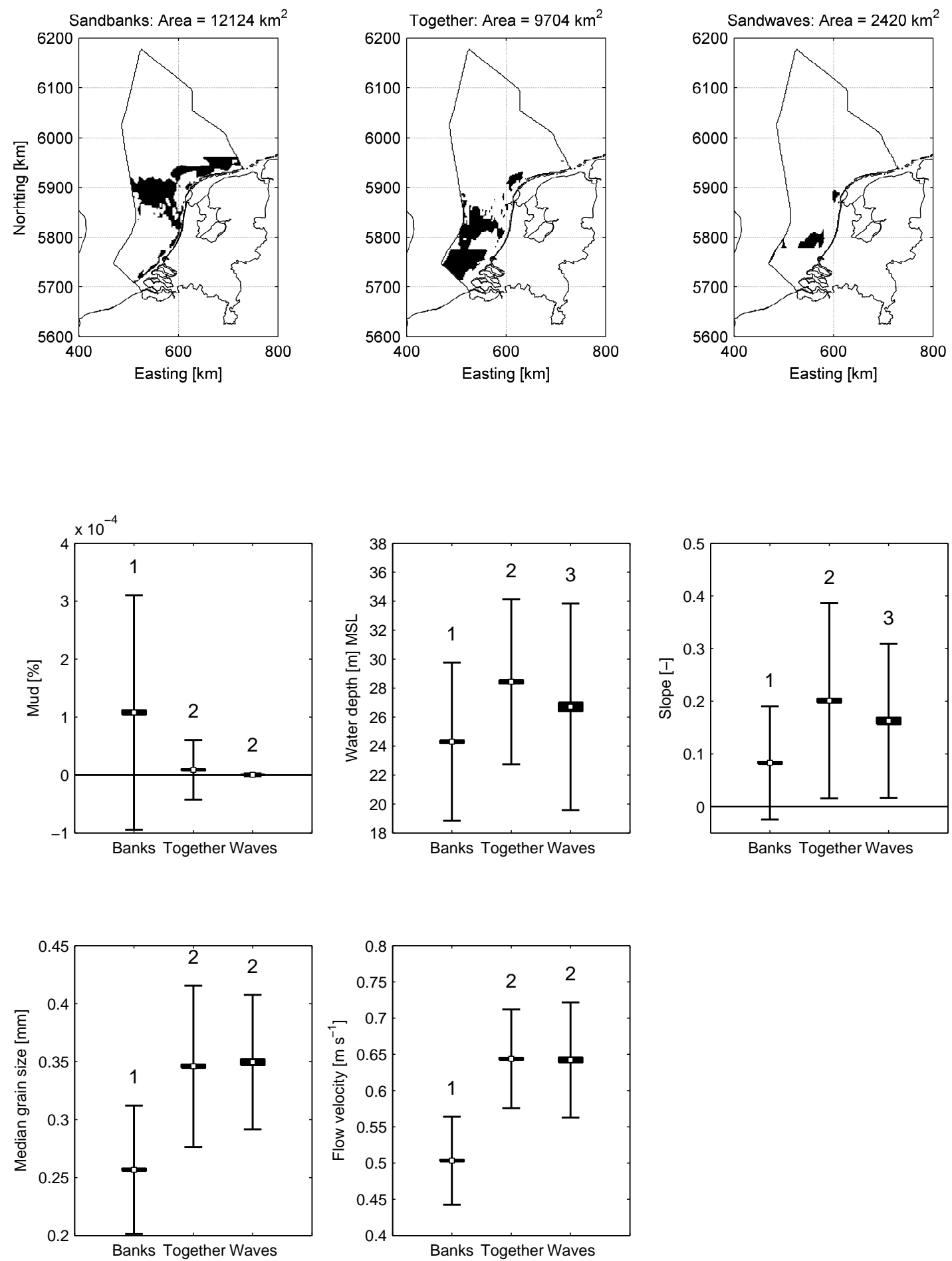

Figure 4.2: Occurrence of sandbanks and sand waves in the Dutch part of the North Sea and the relation to physical parameters. Mean, box: standard error, whiskers: standard deviation. Different numbers (1-3) point to significant differences among means (post hoc LSD test: $\left.p_{0}<0.05\right)$ 

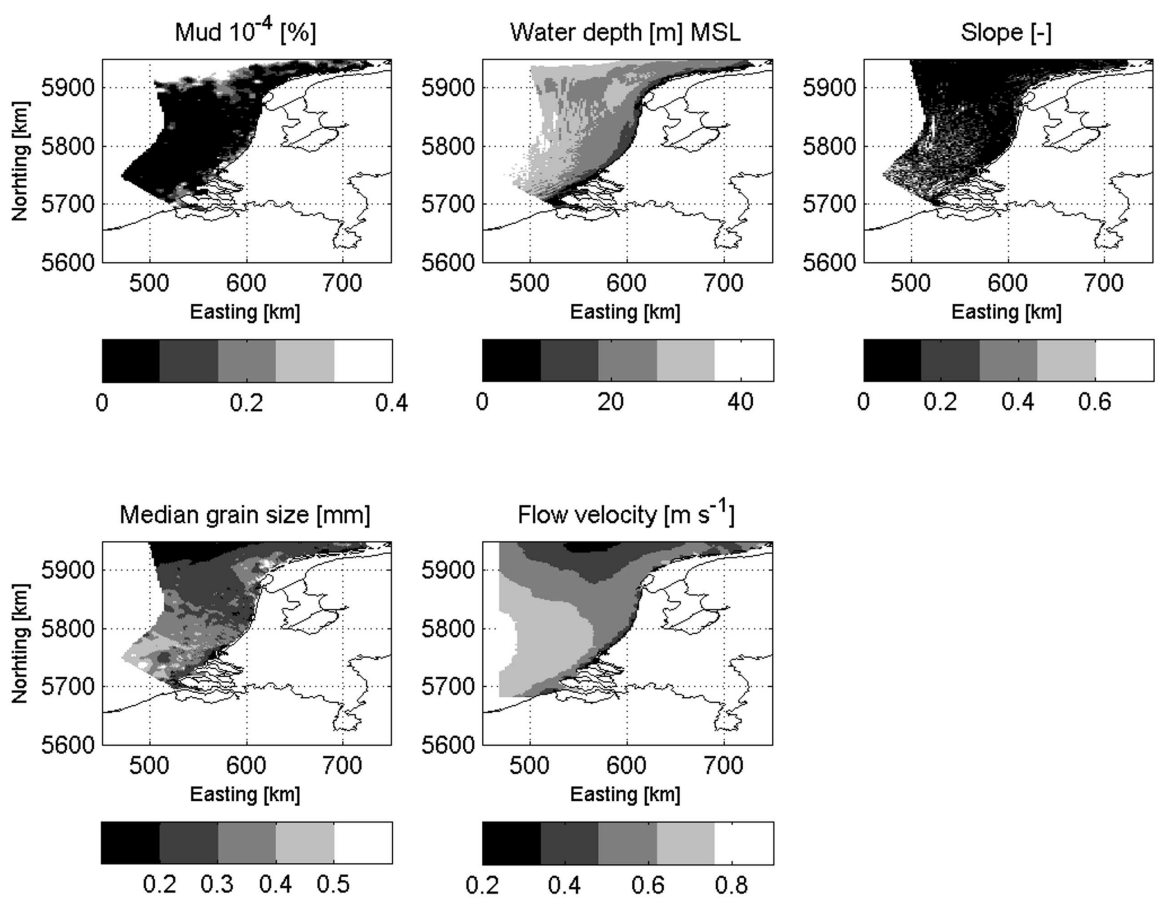

Figure 4.3: Spatial distribution of the physical parameters, focusing on the area of interest (see Figure 4.2 top panels). Grid size is $2 \times 2 \mathrm{~km}$, resulting in nearly 15,000 grid cells for the Dutch part of the North Sea.

\subsection{Impact of subtidal biota on sediment dynamics and hydrodynamics}

The interaction between biota and sediment dynamics has been well studied and clearly shown for the intertidal environment in field studies (e.g. Austen et al., 1999, De Deckere et al., 2001, Andersen et al., 2002), flume experiments (e.g. Widdows et al., 1998, Orvain et al., 2006, Van Duren et al., 2006) and modeling studies (e.g. Paarlberg et al., 2005, Lumborg et al., 2006, Borsje et al., 2008a). From these studies it has become evident that the intertidal biota can influence the hydrodynamics in different ways, like adding roughness to the bottom (e.g., by mussels, Van Leeuwen et al., 2008), or flow deceleration within epibenthic structures (e.g., by vegetations, Bouma et al., 2007). Most importantly, all these studies conclude that biota is able to influence both the sediment dynamics and hydrodynamics by several orders of magnitude and can act on a large spatial (tidal basin) and temporal (seasonal and inter-annual) scale. Compared to the benthos biomass per unit area in intertidal systems, the benthos biomass in subtidal areas in the North Sea is much smaller. Nevertheless, some explorative studies already show that such relatively small benthic biomass can still influence the sediment dynamics significantly (e.g. Knaapen et al., 2003). We will now review the available research for three benthic species that are likely to be relevant for subtidal sandbanks and sand waves: Echinocardium cordatum, Lanice conchilega, and Tellina fabula. 


\section{Biogeomorphological interactions in offshore seabed patterns (not on scale)}

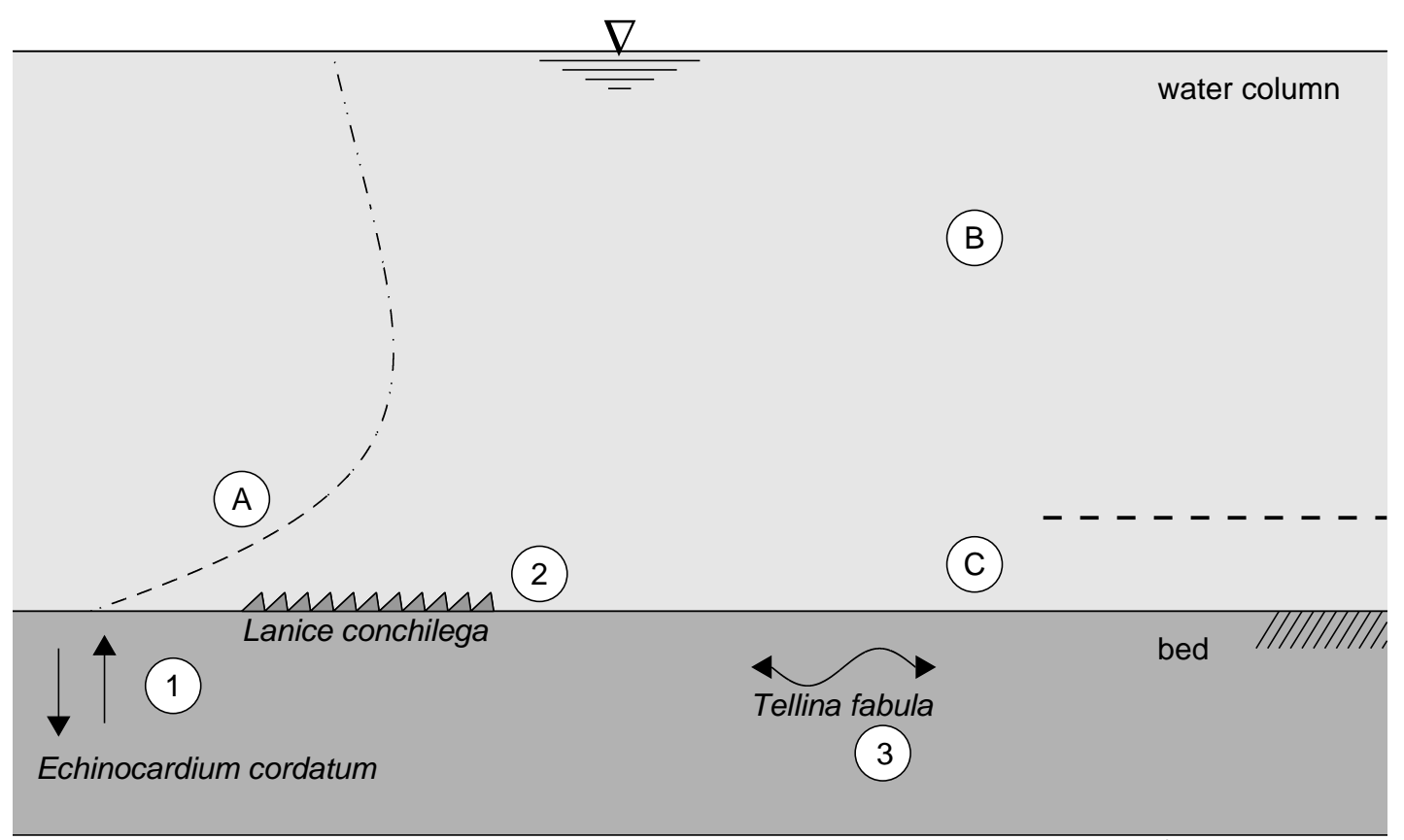

$1=$ transport of fine particles deeper into the sediment $\rightarrow$ larger grain size; $d_{*}^{*}$

2 = lower near bed velocities $\rightarrow$ more sedimentation $\rightarrow$ lower ripple heigth; $\Delta_{r}$

$3=$ disturbance of the surficial sediment structure $\rightarrow$ lower critical bed shear stress; $\theta_{\mathrm{cr}}$

$A=$ Eddy viscosity; $v_{T}^{*}$

$B=$ Suspended sediment concentration; $c(x, y, z)$

$\mathrm{C}=$ Bed load transport; $\mathrm{q}_{\mathrm{Bx}}, \mathrm{q}_{\mathrm{By}}$

Figure 4.4: Schematic overview of the biogeomorphological influences (1-3) by Echinocardium cordatum, Lanice conchilega and Tellina fabula, and the consequences for the sediment dynamics and hydrodynamics (A-C), which will be discussed in Section 4.4.

The sea urchin Echinocardium cordatum has been shown to displace up to 20,000 $\mathrm{cm}^{3} \mathrm{~m}^{-2}$ day ${ }^{-1}$, causing all the surface sediment to be reworked about once every 3-4 days (Lohrer et al., 2005). Moreover, field experiments in the Gullmar Fjord (Western Sweden) show that the reworking intensity was directly related to the biovolume of the E. cordatum individuals (Gilbert et al., 2007). Being a surface deposit feeder, E. cordatum may rapidly transport particles from the sediment surface deeper into the sediment (Osinga et al., 1997), which results in a heterogeneous sediment distribution in the top centimeters of the bed (Figure 4.4). Although E. cordatum is regarded as a non-selective deposit feeder (Lohrer et al., 2005), its feeding activity will for two reasons result in a top layer of the sediment that consists of relatively coarser particles, compared to the default case in the absence of benthos. Firstly, E. cordatum feeds on organic matter. Given that fine sediment is richer in organic matter, compared to coarse sediment (Burone et al., 2003), E. cordatum moves to a new spot after it has reworked all the fine sediment, leaving the coarser sediment particles that are not ingested at their original position on top of the sediment (Cramer et al., 1991). Secondly, the chance to get ingested and brought downward is larger for small particles relative to coarse particles, as finer particles have a relative larger surface area. A comparable non- 
selective deposit feeder (Arenicola marina), is able to double the grain size in the top five centimeters of the bed, compared to the case in which no A. marina was included, for an experiment with initially the same vertical sediment distribution (Baumfalk, 1979).

The tube-building worm Lanice conchilega, is known to occur in high densities which have a decelerating effect on the near bottom flow, and thereby cause fine particles to deposit within such patches (Eckman et al., 1981, Rabaut et al., 2007). Given both the lower near-bottom flow velocity and a smaller median grain size at the sediment surface compared to the default case in the absence of benthos, the ripples on top of the sediment surface are lower (Figure 4.4), as observed in the field by Featherstone and Risk (1977). Such an effect is highly important, as ripples are the main origin of sea bed roughness and one of the main determinants of the amount of sediment transported (Soulsby, 1983). Given the maximum density of L. conchilega found in the North Sea (3000 ind. $\mathrm{m}^{-2}$ ) the near bottom velocity will reduce to $30 \%$ of the near bottom flow, relative to the default case, according to the flume experiment by Friedrichs et al. (2000). Such flow reduction will decrease the ripple height up to $70 \%$, based on empirical relations given by O'Donoghue et al. (2006).

The bivalve Tellina fabula is a selective deposit feeder as well as a suspension feeder. Due to its burrowing and feeding activities, the surficial sediment structure is disturbed, making it more prone to erosion (Austen et al., 1999). Data on the ecosystem engineering species capacity of the bivalve $T$. fabula are scarce, but the sediment modification by the bivalve Macoma balthica is much better known (e.g. Widdows et al., 2000). Whereas both bivalves have comparable feeding strategies, they occur in quite different sediment types: $M$. balthica is mostly found in muddy sediments, while $T$. fabula prefers fine sand. Therefore, the distribution of $M$. balthica is concentrated in muddy estuaries and bays, like the Wadden Sea, and in a narrow zone along the coast, in contrast to T. fabula which can be found in all other parts of the North Sea. Based on field measurements, Borsje et al.(2008a) constructed a parameterization of the relation between the biomass of $M$. balthica and the critical bed shear stress. At low biomass, the grazers cause a large modification of the critical bed shear stress, whereas at high biomass the grazers will not further reduce the critical bed shear stress. In other words, for large biomass grazers, the critical bed shear stress is estimated to be about $60 \%$ compared to the critical bed shear stress for the default case.

\subsection{Modeling the role of biogeomorphological influences on seabed patterns}

As first pointed out by Huthnance (1982), bed patterns associated with tides are often free instabilities of the sea bed, originating from the interaction between the sandy sea bed and the depth-averaged water motions induced by tide propagation. Hulscher (1996) elaborated on this idea, and found that sand waves are generated by residual vertical circulation cells, whereby sediment at the trough is transported towards the crests. The occurrence of sand waves and sandbanks can be fairly predicted for the North Sea in both a qualitative (Hulscher and van den Brink, 2001) and quantitative way (Cherlet et al., 2007). The latter two studies both used linear stability analysis to determine a specific wave length and an orientation of the most unstable component of the bed perturbations, which can be assumed to coincide with the appearing bedform. For a detailed explanation on the theory behind the use of linear stability analysis for 
understanding morphodynamic behaviour of coastal systems see Dodd et al. (2003).

The model used in the present chapter is based on the work by Besio et al. (2006) and later modified by Cherlet et al. (2007), who modeled sand wave lengths along the Belgium continental shelf. By linking the relations described in Section 4.3 with the idealized model of Cherlet et al. (2007), a first insight can be obtained into the possible influence of benthos on the wave length and occurrence of offshore sand waves.

In order to perform the linear stability analysis, firstly the flow field must be evaluated and secondly a predictor for the sediment transport rate needs to be imposed. The parameterization of biological activity on the hydrodynamics and sediment transport is discussed in Section 4.4.1. The results of the inclusion of biogeomorphological influences in the model are subsequently discussed in Section 4.4.2.

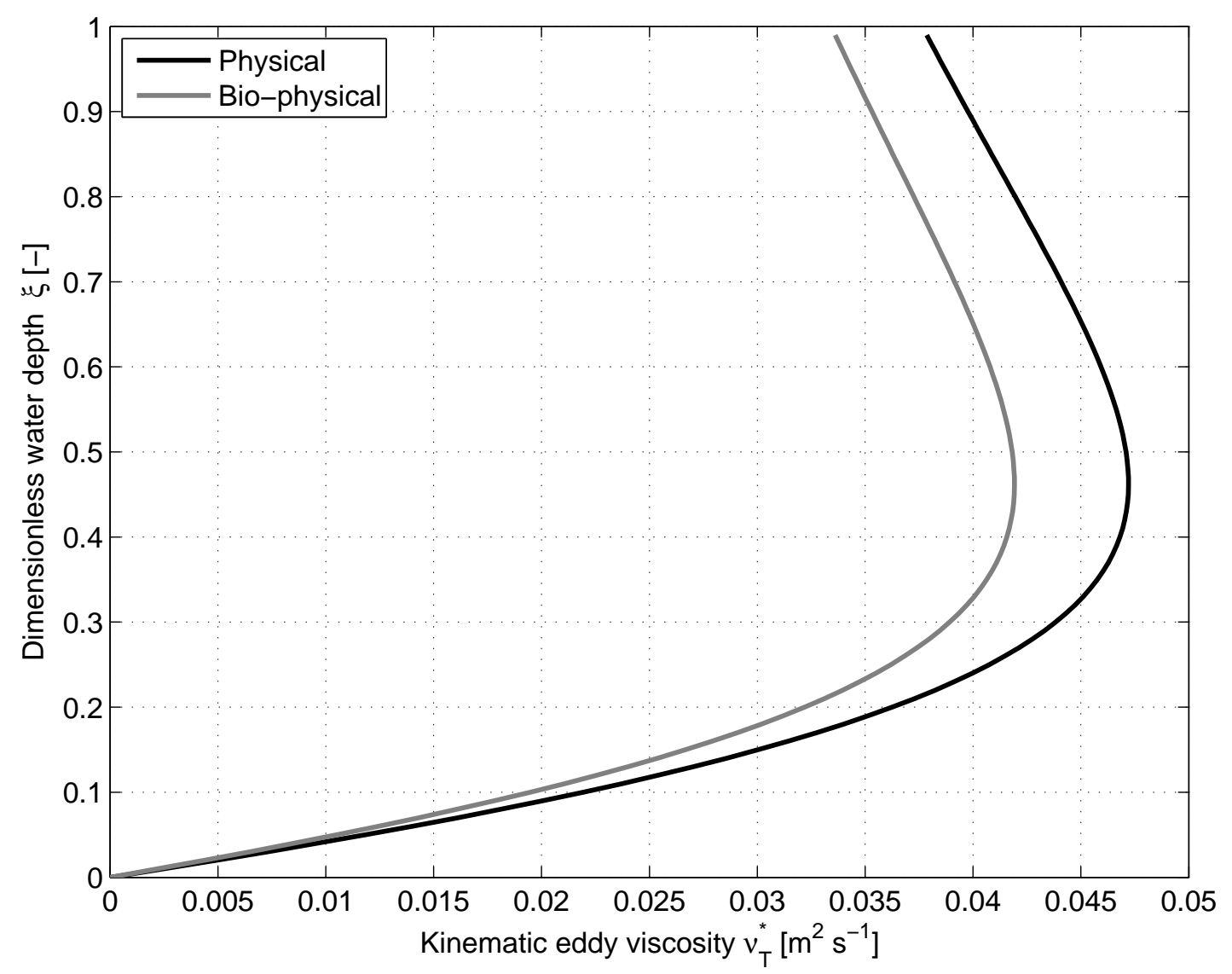

Figure 4.5: Kinematic eddy viscosity $\left(\nu_{T}^{*}\right)$ plotted against dimensionless water depth $(\zeta)$ for the physical case and the case in which biological activity by Lanice conchilega is included. Kinematic eddy viscosity profile is shown for a typical North Sea case: water depth $h_{0}^{*}=25 \mathrm{~m}$, grain size $d^{*}=0.3 \mathrm{~mm}$ and flow velocity is $U_{0}^{*}=0.6 \mathrm{~m} \mathrm{~s}^{-1}$. Consequently, the ripple height in the default case $\left(\Delta_{r}^{* 0}\right)$ is much larger compared to the bio-physical case $\left(\Delta_{r}^{*}\right)$. 


\subsubsection{Parameterization of biological activity}

Borsje et al. (2008a) suggested to quantify the influence of the biological activity by:

$$
\Delta_{r}^{*}=\Delta_{r}^{* 0} f_{\text {Lanice,stab },}
$$

where $f_{\text {Lanice,stab }}$ is the biological factor for the ripple height $\left(\Delta_{r}^{* 0}\right)$. The superscript '0' for the ripple height represents the value without the influence of biological activity (default). A star denotes dimensional quantities. The biological factor is dependent on the abundance of $L$. conchilega. As discussed in Section 4.3, the minimum value for $f_{\text {Lanice,stab }}$ for the North Sea area is 0.3 .

By adopting a representative North Sea case (water depth $=25 \mathrm{~m}$; grain size $=0.3$ $\mathrm{mm}$; flow velocity $=0.6 \mathrm{~m} \mathrm{~s}^{-1}$; Figure 4.2) and reducing the ripple height to $30 \%$, the eddy viscosity profile shows a clear biological influence compared to the physical case without biology (Figure 4.5). For the given parameter settings, the default ripple height is $20 \mathrm{~mm}$. However, the L. conchilega abundance will reduce the ripple height to $6 \mathrm{~mm}$. The corresponding lower eddy viscosity causes both lower suspended sediment concentrations and lower bedload transport rates, compared to the default case that does not include biological effects. In relative terms, the decrease in suspended load transport is large compared to the decrease in bedload transport, as the eddy viscosity is mainly influenced in the suspended load region, and not close to the bed, where the bedload transport takes place. Moreover, a lowering of the ripple height is related to a lowering of the bed shear stress, resulting in lower bedload transport rates and suspended sediment concentrations, compared to the default case. Accordingly, the wave length of the sand waves will become smaller compared to the default case.

Similar to the biological influence by L. conchilega, the influence of the biological activity by $T$. fabula and E. cordatum can be quantified by:

$$
\begin{gathered}
\theta_{c r}=\theta_{c r}^{0} f_{\text {Tellina,destab },} \\
d_{50}^{*}=d_{50}^{* 0} f_{\text {Echinocardium,stab }},
\end{gathered}
$$

where $f_{\text {Tellina,destab }}$ and $f_{\text {Echinocardium,stab }}$ are the (de)stabilizing biological factors for the critical bed shear stress and grain size, respectively, $\theta_{c r}$ is the critical Shields parameter below which no sediment moves and $d_{50}^{*}$ is the median grain size. Again, the superscript ' 0 ' for the critical bed shear stress and the median grain size represent the values without the influence of biological activity (default). The biological factor is dependent on the abundance of T. fabula and E. cordatum. As discussed in Section 4.3, the minimum value for $f_{\text {Tellina,destab }}$ for the Dutch part of the North Sea area is 0.6 , while the maximum value for $f_{\text {Echinocardium, stab }}$ is 2 .

Burrowing and grazing activities by T. fabula cause a decrease in critical bed shear stress. Consequently, both the bedload and suspended load transport will increase. The exact influence on the wave length of sand waves is difficult to predict, since the contribution of both transport modes to the sand wave length depends on the physical conditions. For low flow velocities, the suspended load is small, and bedload transport rates will be relatively higher compared to the default case, due to the decrease in critical bed shear stress. Consequently, the wave length of sand waves will be smaller, relative to the default case. However, for higher flow velocities, the rate of suspended load becomes important and its presence provides a stabilizing contribution to the process leading to sand wave formation. As a result, the wave length of sand waves will be longer, compared to the default case. E. cordatum redistributes the sediment, 
resulting in a larger median grain size at the sediment-water interface, compared to the default case. First of all, the bedload and suspended load transport will decrease, due to the larger grain size and consequently a larger critical bed shear stress. Moreover, an increase in grain size will result in a higher roughness height, and therefore higher bed shear stresses. In contrast, a lower roughness height is induced by L. conchilega. In summary, the overall effect of different types of biota on the sand wave length is difficult to predict, given the various influences on the different model parameters. Therefore, including the extreme biological factors in the idealized model (Cherlet et al., 2007) is valuable to give some insight into the possible influence biota have on the sand wave length and sand wave occurrence.
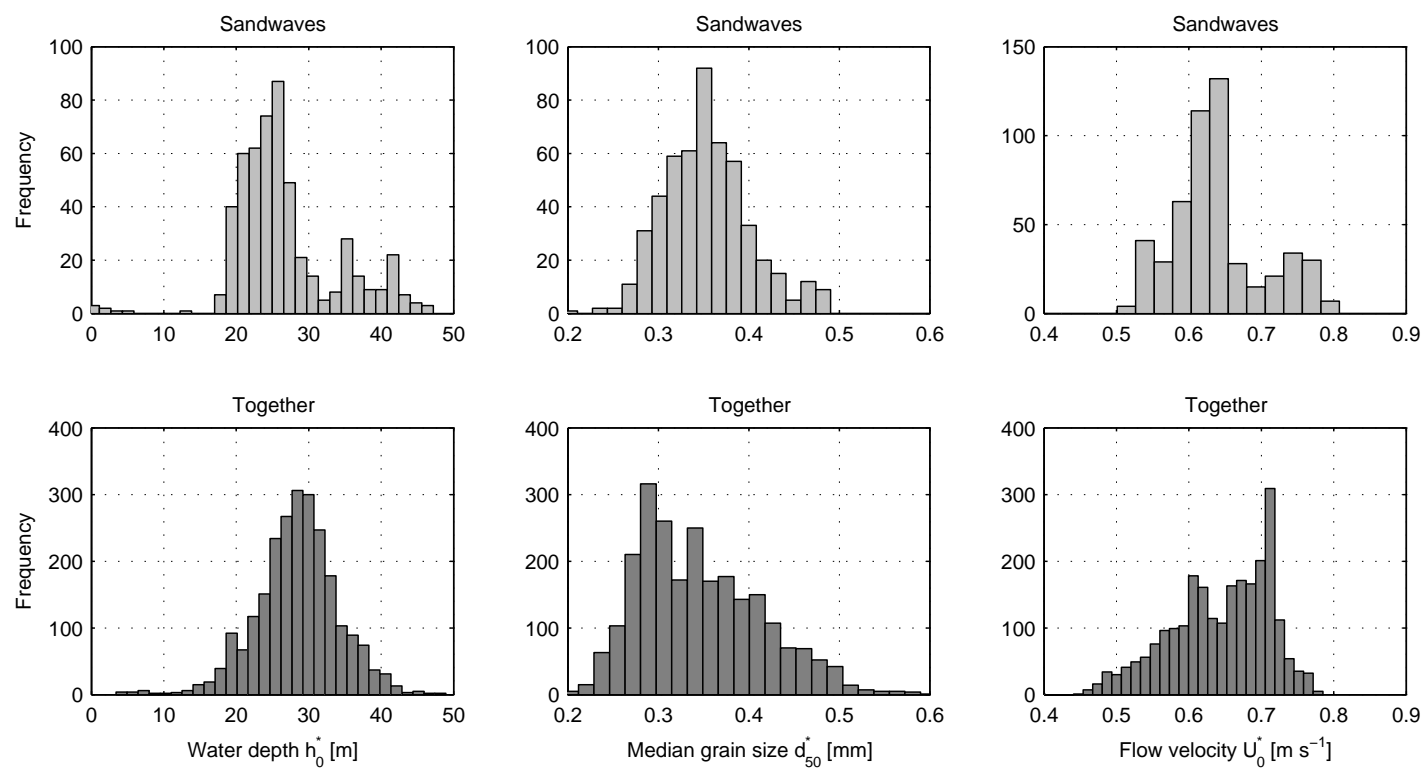

Figure 4.6: Histograms plots for water depth $\left(h_{0}^{*}\right)$, median grain size $\left(d_{50}^{*}\right)$ and flow velocity $\left(U_{0}^{*}\right)$. Distinction between areas where sand waves occur (top panels) and areas where both sand waves and sandbanks occur (lower panels), for reference see Figure 4.2 . 
Table 4.1: Range of process parameters used in the idealized biogeomorphological model for the local water depth $h_{0}^{*}$, grain size $d^{*}$ and flow velocity $U_{0}^{*}$.

\begin{tabular}{llll}
\hline & Mean & Minimum & Maximum \\
\hline$h_{0}^{*}[\mathrm{~m}]$ & 30 & 20 & 40 \\
$d^{*}[\mathrm{~mm}]$ & 0.35 & 0.2 & 0.5 \\
$U_{0}^{*}\left[\mathrm{~m} \mathrm{~s}^{-1}\right]$ & 0.65 & 0.5 & 0.8 \\
Tellina fabula & - & - & $\theta_{c r}=0.6 \theta_{c r}^{0}$ \\
Lanice conchilega & - & - & $\Delta_{r}^{*}=0.3 \Delta_{r}^{* 0}$ \\
Echinocardium cordatum & - & - & $d^{*}=2 d^{* 0}$ \\
\hline
\end{tabular}

\subsubsection{Modeling results}

The model is run for two different cases: using the default parameter settings without including biological activity (default case) and a case in which the transport parameters are modified by the presence of biological activity (bio-physical case). All model parameters are listed in Table 4.1. The range in model parameters is based on the histogram plots for the water depth, flow velocity and median grain size (Figure 4.6). Figure 4.7 shows the wave length for both cases in which two of the process parameters are kept constant (mean), and the third process parameter is varied according to the range shown in Table 4.1.

The results for the default case are in accordance with the results discussed by Borsje et al. (2008b), and are only discussed briefly hereafter. By increasing the water depth (left panels Figure 4.7), the wave length for the sand waves in the default case grow almost linearly. This observation is the result of a decrease in the Shields parameter for an increase of water depth, causing lower transport rates and resulting in longer sand waves (Besio et al., 2006). By increasing the median grain size (middle panels Figure 4.7) the default model results first in a shorter wave length. This reduction in wave length is caused by a decrease in suspended sediment concentrations for increasing grain sizes, since the presence of suspended sediment tends to increase the wave length of sand waves. However, once a critical grain size threshold is passed (i.e., $d_{50}^{*}$ around 0.45 $\mathrm{mm}$ ), the wave length of the sand waves increase strongly with grain size, as sediment is only transported as bedload (middle panels Figure 4.7).

Finally, an increase in flow velocity (right panels Figure 4.7) causes a decrease in wave length, indicating that stronger tidal currents tend to generate shorter sand waves. However, the wave length of the sand waves does reach a minimum. The latter may be explained that in case of very strong tidal currents, the suspended sediment provides a stabilizing mechanism, resulting in sand waves with an almost constant wave length.

The results for the bio-physical case show a clear difference, compared to the default case. E. cordatum initiated longer sand waves compared to the physical case. For almost all other model settings, less sediment is transported as both bedload and suspended load in the case for which E. cordatum is included, resulting in longer sand waves. The contradiction for small grain sizes is due to the fact that small grain sizes are related to high suspended sediment concentrations and therefore to longer sand waves. However, due to the presence of E. cordatum the suspended sediment concentrations for small grain sizes are significantly lower, because the grain size at the bed-water interface is doubled. Consequently, the wave length for this typical model settings is 
smaller, compared to the default case.

The influence of $L$. conchilega is clearly opposite to the effect of E. cordatum, as $L$. conchilega causes sand waves to become shorter compared to the physical case (Figure 4.7). The main difference for the case in which L. conchilega is included relative to the case in which E. cordatum is included, is that the former species follows almost the same trend compared to the physical case, whereas the latter species is able to influence both the position and the trend of the line compared to the physical case.

The effect of $T$. fabula on the wave length of the sand waves is limited for current model parameter settings. As discussed before, T. fabula is only influencing the critical bed shear stress. Consequently, in the case where sediment transport is already present, as was the case for our model, T. fabula is hardly influencing the amount of bedload or suspended load transport, and therefore of limited influence on the wave length of the sand waves (Figure 4.7). However, in those physical cases where hardly any sediment transport is initiated, T. fabula is able to have a significant influence on the wave length of sand waves, as shown by Borsje et al. (2008b) for the Belgium Continental Shelf.

We subsequently modeled sand waves at three locations in the North Sea, that were selected based on their contrasting process parameters (Table 4.2). For every location, the model could give three distinctive outcomes. First, sand waves are modeled with a
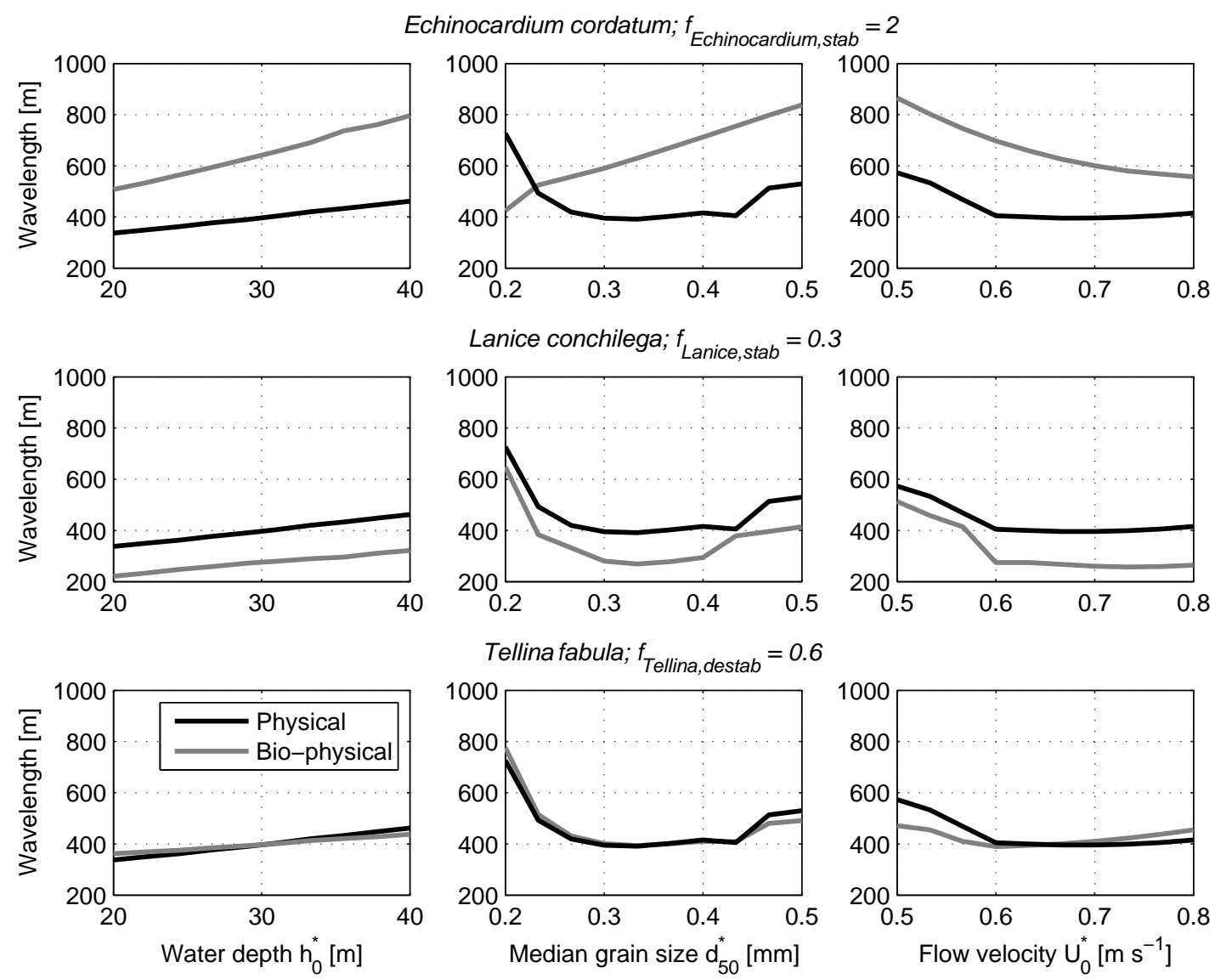

Figure 4.7: Model results for the physical case (black line) and bio-physical case (gray line), for the three different ecosystem engineering species (rows), and variation in the three different process parameters (columns). For reference see Table 4.1. 
Table 4.2: Model settings for the local water depth $h_{0}^{*}$, grain size $d^{*}$ and flow velocity $U_{0}^{*}$, used to construct Figure 4.8 .

\begin{tabular}{llll}
\hline & Location 1 & Location 2 & Location 3 \\
\hline$h_{0}^{*}[\mathrm{~m}]$ & 25 & 5 & 40 \\
$d^{*}[\mathrm{~mm}]$ & 0.2 & 0.3 & 0.5 \\
$U_{0}^{*}\left[\mathrm{~m} \mathrm{~s}^{-1}\right]$ & 0.8 & 0.8 & 0.5 \\
\hline
\end{tabular}

certain wave length (bars in Figure 4.8). Secondly, no sediment transport is initiated (squares in Figure 4.8). Finally, in some cases the bed turns out to be stable and flat due to the stabilizing effect of suspended sediment (triangles in Figure 4.8). Location 1 is characterized by a high flow velocity, small grain size and a moderate water depth. As a result, suspended sediment concentrations are high, resulting in a stable flat bed. However, due to the presence of E. cordatum the grain size at the sediment water interface is larger, relative to the default case. This higher grain size results in lower suspended sediment concentrations, and therefore a less destabilizing effect on the bed. Consequently the presence of E. cordatum allows the triggering of the formation of a wavy bed pattern, while in all other cases the bed is flat. Location 2 only differs from
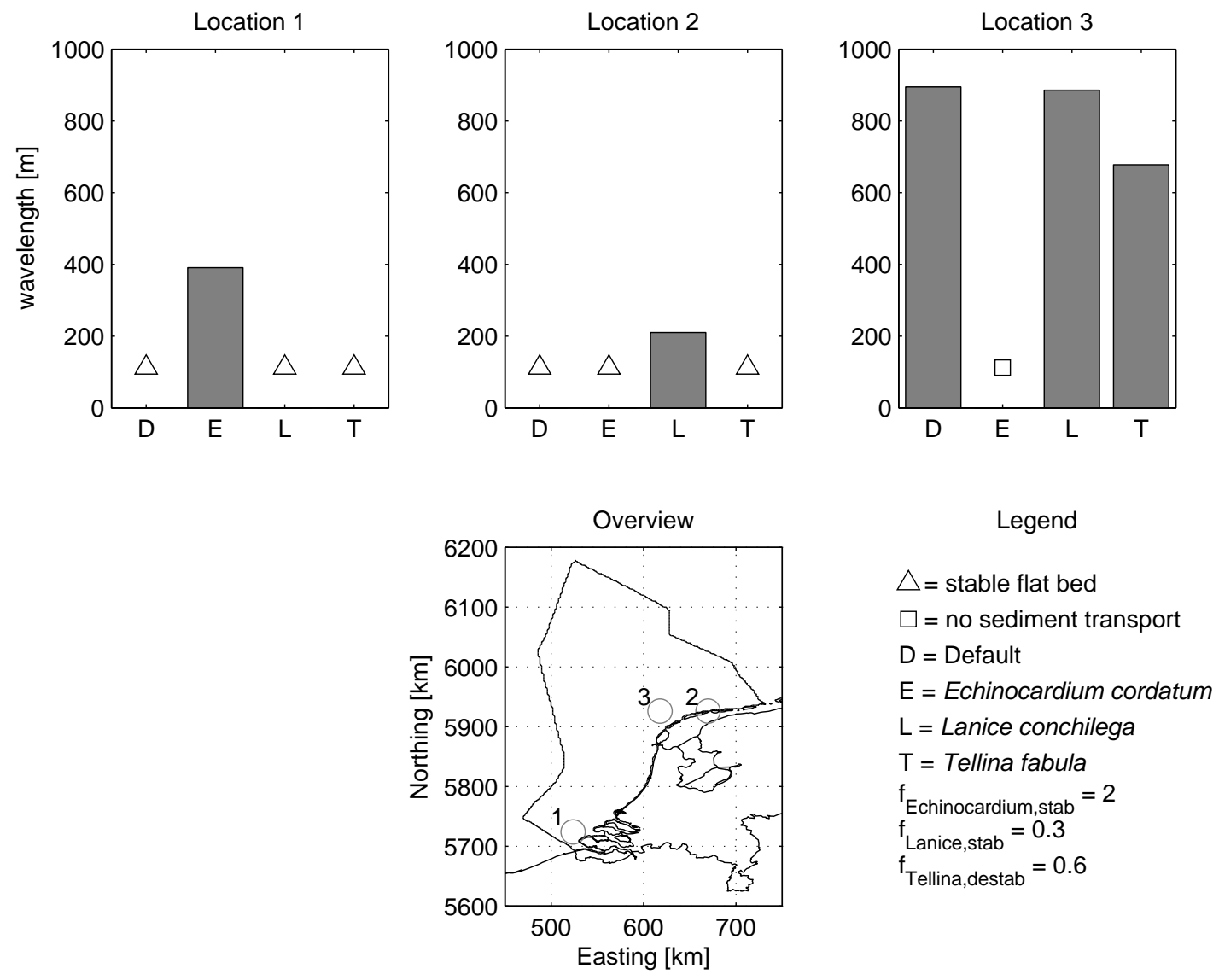

Figure 4.8: Model results for the occurrence of bedforms, for three different location on the Dutch part of the North Sea. Process parameters are shown in Table 4.2. 
location 1 by having a much smaller water depth and a slightly larger median grain size. Similar to what we found for location 1, in most cases, the bed at location 2 also turns out to be a stable flat bed. The model however predicts that L. conchilega is able to reduce the ripple height, and thereby preserving a wavy bed pattern. Finally, location 3 is characterized by a large water depth, and both a moderate flow velocity and grain size. In most cases, sediment is transported and sand waves appear. However, the model indicates that at this location, E. cordatum will increase the grain size of the bed material and as a consequence, the sediment will not be transported.

Based on these model simulations, we conclude that ecosystem engineering species can influence both the wave length and the presence of bedforms significantly.

\subsection{Discussion}

This chapter explored the biogeomorphological influences in offshore seabed patterns, using a model analysis of the interaction between hydrodynamics, geomorphodynamic and biological processes. From the biogeomorphological loop (i.e., an extension of the morphological loop described by Roos and Hulscher, 2003) it is clear that each of these processes have different temporal and spatial scales (Figure 4.9). The separation in three timescales is essential, as the interaction between hydrodynamics, sediment transport and biological processes act within a tidal cycle (half a day) and the bed evolution acts on a much longer time (decades to centuries). The time scale on which the biological processes alter is seasonal. However, there are also strong indications that biological processes may differ on a much longer time and spatial scale, for example, due to a northerly shift in geographical distribution of key species as a result of global warming (Widdows and Brinsley, 2002).

Besides, there are also strong indications that a feedback exists from the bed evolution to the biological community and the processes they influence (e.g. Ryan et al., 2007). For example, Daniell et al. (2008) found a relation between the occurrence of seagrass beds on the one hand and dune migration and sand supply on the other hand. In the present model study, we explored a limited but important number of biological effects within the biogeomorphological feedback loop (i.e., black arrows in Figure 4.9). It is an important challenge for the future to extend these kind of explorations by including both temporal scales plus feedbacks from changes in hydrodynamics, sediment transport and bed evolution to the biological activity (white arrows in Figure 4.9). For this purpose, we first need a better parameterization of the biological activity to include in idealized models and good field data sets for model validation.

Validation of the model results is partly feasible by linking the modeled occurrence of bedforms (Figure 4.9) with the observed occurrence of bedforms (Figure 4.2). However, the presence of biota at the three locations is not explicitly known. Nevertheless, the observed presence of bedforms at location 1 is not in accordance with the default model settings for location 1, suggesting that ecosystem engineering species might be responsible for the occurrence of bedforms at these typical locations. As we have no further information, we cannot verify this hypothesis.

It will also be an important challenge to incorporate anthropogenic influences in future model studies, as human activities may strongly affect biological communities (e.g. bottom trawling, foreshore nourishments, sand mining, dredging activities, construction of offshore wind farms). Given the biogeomorphological influences shown in this chapter, seabed morphology could drastically change when benthic species that act 
as ecosystem engineering species are disturbed by anthropogenic factors. Consequently, we argue that the assessment of human activities on the seabed not only needs to take into account a change in physical processes (e.g. currents, sediment composition, water depth) and the direct influence on the ecosystem, but also the change in biomass of ecosystem engineering species and thereby on seabed morphology. The model proposed in this chapter offers a valuable example on how such problems may be addressed.

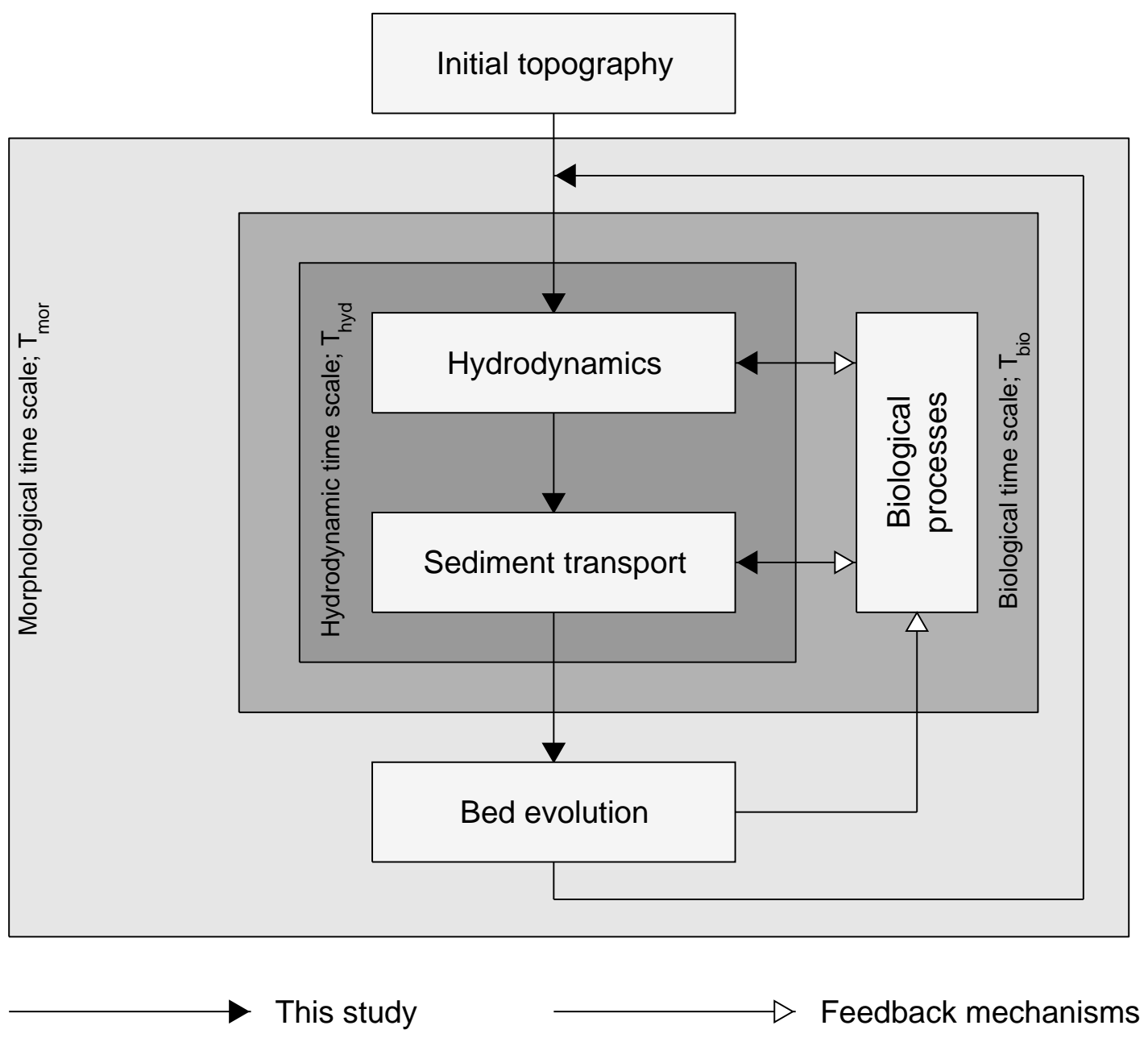

Figure 4.9: The bio-morphological loop, which consists of water movement (hydrodynamics), transport of sediment, biological processes and bed evolution. Starting from an initial topography, the water movement initiates the transport of sediment. Both the hydrodynamics and sediment transport are influenced by biota. The fast time scale of the interaction between hydrodynamics, sediment transport and biological processes compared to the slow time scale of bed evolution, allows us to only focus on the tidal average sediment transport. The result is an updated topography, which is the input to start again the computation of the hydrodynamics and sediment transport rates. 


\subsection{Conclusions}

The Dutch part of the North Sea is not only characterized by different seabed patterns, but also by a diverse biological community. Some ecosystem engineering species within this benthic community are able to significantly influence the sediment transport processes and hydrodynamics in the North Sea area, and thereby have a direct relation to the morphodynamics of the seabed. Firstly, the sea urchin Echinocardium cordatum feeds from the surface sediment layer and brings fine sediment particles to the deeper sediment and consequently influences the vertical sediment distribution. Secondly, the clam Tellina fabula makes the top layer of the sediment more prone to erosion due to its burrowing and grazing activities. Accordingly, the critical bed shear stress for erosion is reduced. Finally, the tube-building worm Lanice conchilega reduces the near bottom flow and by this facilitates the deposition of fine material. As a result, the ripple height on top of the bed forms is reduced.

By including the maximum likely modification of the transport parameters by these ecosystem engineering species in an idealized sand wave model, an initial insight is given into the biogeomorphological interactions in offshore seabed patterns. First of all, the wave length of the bed forms is significantly influenced and even more important: stabilizing ecosystem engineering species are able to preserve a stable flat bed, while the physical conditions suggest bed patterns. Likewise the opposite effect is induced by destabilizing benthos.

Future research should focus on improving the parameterization of biological activity on the sediment transport parameters, and thereby generate a tool to extend current models with both seasonal variation in biological activity and feedbacks from seabed evolution to the composition of the biological community. Moreover, gathering site specific field data both on physical parameters and biological activity will help to validate the proposed modeling approach. 


\section{Chapter 5}

\section{On the paramaterization of biological influences on offshore sand wave dynamics}

This chapter has been published as:

B.W. Borsje, S.J.M.H. Hulscher, P.M.J. Herman, M.B. de Vries, 2009. On the paramaterization of biological influences on offshore sand wave dynamics. Ocean Dynamics 1-13. doi: 10.1007/s10236-009-0199-0.

\footnotetext{
Abstract - The bed of the North Sea is covered by sand waves and houses a great number of macrobenthic animals. These ecosystem engineering species are known to have significant influence on the stability of the bed and thereby on the geomorphology of the seabed. This chapter proposes a parameterization of these biogeomorphological interactions.

Given the abundance of three dominant ecosystem engineering species on the Dutch Continental Shelf, the predicted occurrence of sand waves, in which the parameterization is included, shows significantly better results, compared to the prediction for the default case without biology. Therefore, the inclusion of biological activity could be important to predict the occurrence of sand waves.
} 


\subsection{Introduction}

The interaction between benthos and sediment dynamics in the intertidal area has been exhaustively documented (e.g. Widdows and Brinsley, 2002, and references therein). They show that benthos are able to influence the strength of the bed by several orders of magnitude, and thereby have a significant influence on the sediment dynamics on a large spatial and temporal scale, either by stabilizing or destabilizing the sediment (Borsje et al., 2008a). However, benthos are also present in shallow shelf sea (Heip et al., 1992; Künitzer et al., 1992; Rabaut et al., 2007), for which the North Sea is an example. Although the biomass in the North Sea area is much smaller compared to the benthos biomass per unit area in intertidal area, we still expect strong interactions in the North Sea area (Borsje et al., 2009a; Chapter 4). At the bed of the North Sea, sand waves are excessively present; these rhythmic features can grow up to $25 \%$ of the water depth and migrate with a speed up to tens of meters per year (Tobias, 1989). The migration of these sand waves can conflict with economic interests like navigation and the exposure of oil pipes or telecommunication cables (Morelissen et al., 2003; Németh et al., 2003). Sand wave occurrence in the North Sea was first modeled by Hulscher and van den Brink (2001). Van der Veen et al. (2006) improved the prediction of sand wave occurrence by including both a spatially varying grain size and a threshold for erosion (critical bed shear stress). Recently, different models were proposed (Besio et al., 2006; Németh et al., 2007) by which also the dimensions (wave height and wave length) and migration of sand waves can be predicted. However, all models lack inclusion of biological activity. In order to predict these biogeomorphological interactions in offshore sand wave occurrence, we first need a tool to correct the hydrodynamics and sediment dynamics for biological activity. The aim of this chapter is (i) to propose a parameterization in which biological activity is expressed in physical parameters, and (ii) to validate this parameterization with field data from the Dutch North Sea. The chapter is organized as follows. Section 5.2 describes the selection and the parameterization of three benthic species. The validation of the parameterization is discussed in Section 5.3, where the occurrence of sand waves for the Dutch part of the North Sea is modeled both for the case without biological activity and the case in which the parameterization is included. The main findings of this chapter are discussed in Section 5.4, and we draw conclusions in Section 5.5.

\subsection{Parameterization of biological activity}

Three benthic species are included in the parameterization on the basis of (i) their abundance in the North Sea, (ii) their strong modification of the environment they are living in, and (iii) their contrasting type of feeding and burrowing, and thereby contrasting influence on the sediment dynamics and hydrodynamics. The three species selected are Lanice conchilega, Tellina fabula and Echinocardium cordatum. The selection of the benthic species is discussed in more detail by Borsje et al. (2009a; Chapter 4). The interaction between the selected benthos and the environment is schematized in Figure 5.1. The tube-building worm L. conchilega protrudes several centimeters from the sediment in the water column, and thereby influences the near-bottom flow. For dense tube assemblages the near-bottom flow reduces, fine sediment will deposit and consequently lower ripples are present (Figure 5.1B), compared to the default case (Figure 5.1A). Due to the digging and feeding activities of the bivalve T. fabula up 
(A)

(B)

(C)

(D)

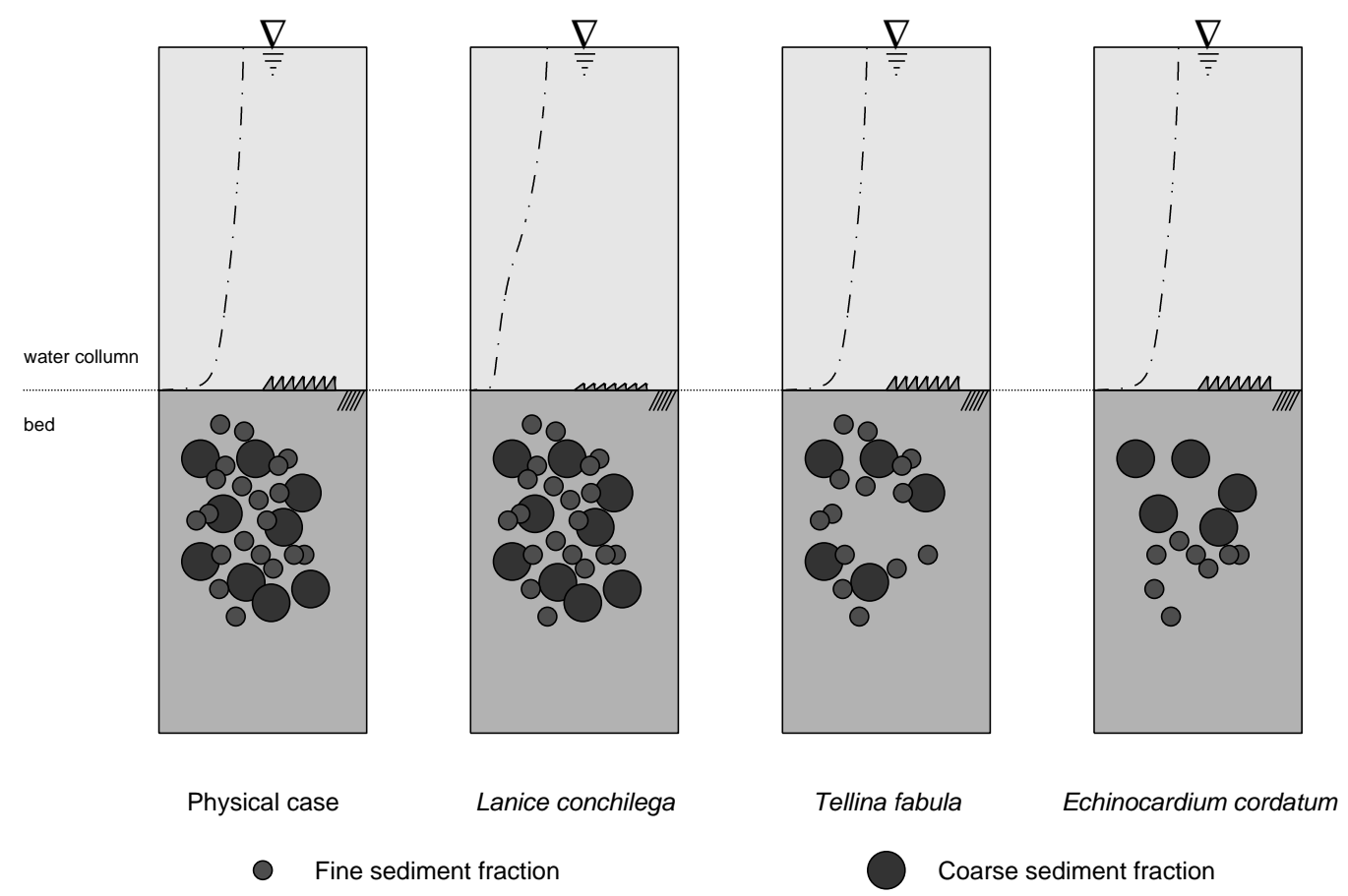

Figure 5.1: Schematized interaction between the selected benthos and their environment. For the default case (A), the sediment fractions are normally distributed over the bed, ripples are present at the sediment-water interface, and the flow velocity profile represents the normal case. Lanice conchilega (B) reduces the near-bottom flow, and hence, the ripples are lowered. Tellina fabula (C) destabilizes the sediment and thereby increases the pore volume. Echinocardium cordatum (D) redistributes the sediment, resulting in a coarser surface layer and a finer subsurface layer.

to $10 \mathrm{~cm}$ deep in the sediment, the properties of the surficial sediment are modified and the sediment is more prone to erosion (Figure 5.1C). Finally, the sea urchin E. cordatum lives in the top 20 centimeters of the bed and segregates sediment in vertical direction (Figure 5.1D), resulting in relatively coarser sediment in the top layer of the bed. Both the stabilizing and destabilizing effects of benthic organisms are parameterized by means of modification of the model parameters, following the suggestion by Knaapen et al. (2003):

$$
x^{b i o}=x^{0} f_{\text {species },(d e) \text { stab }},
$$

in which $x$ is the model parameter, which is influenced by biological activity. The superscript 'bio' represents the value of the parameter $x$ due to biological activity and the superscript ' 0 ' represents the value of the parameter without the influence of biological activity. The parameter $f_{\text {species, }(d e) s t a b}$ represents the stabilizing effect and destabilizing effect of the different benthic organisms respectively. The (de)stabilizing effect is a function of the biomass/abundance of the benthic organisms, as will be discussed for the individual species in the following sections. 

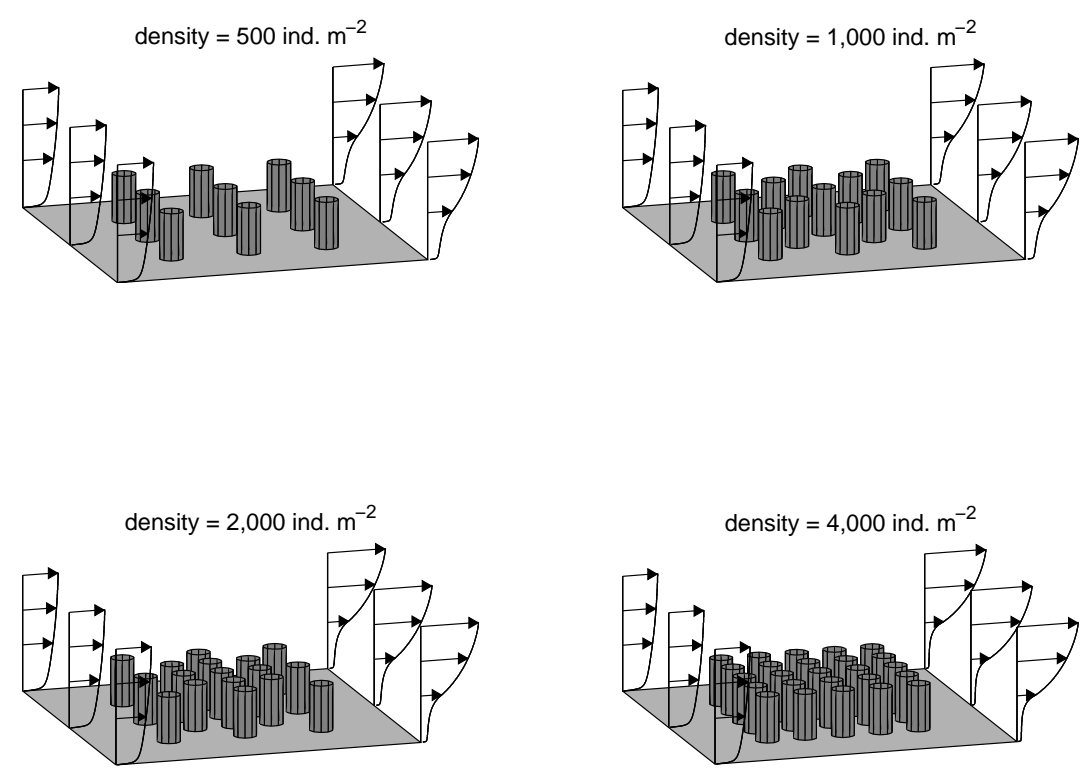

Figure 5.2: Schematic overview of the model set-up to determine the reduction of the flow velocity by Lanice conchilega.

\subsubsection{Tube-building worm - Lanice conchilega}

To model the influence of L. conchilega on the near bottom flow, we represent the tube-building worm by thin piles on the bottom of the seabed. In this way, we are able to include the worms in a vegetation model (Uittenbogaard, 2003). This vegetation model is able to calculate the turbulent flow over and through vegetation (thin piles) in water of limited depth. The vegetation model explicitly accounts for the influence of cylindrical structures on drag and turbulence (Chapter 6). The vegetation model is included in Delft3D-FLOW model, which is a three-dimensional hydrodynamic model (Lesser et al., 2004). The Delft3D-FLOW model computes flow characteristics (flow velocity, turbulence) dynamically in time over a three-dimensional spatial grid. For a detailed mathematical description of the vegetation model see Dijkstra and Uittenbogaard (2010).

Validation of the model outcome is done for two cases. In both cases L. conchilega was mimicked by artificial tubes placed in a regular pattern (Figure 5.2). Flow velocity profiles in front of the tube field and after the tube field are compared. The first case consists of a flume experiment with an abundance of 350 individuals $\mathrm{m}^{-2}$, a free stream velocity of $0.1 \mathrm{~m} \mathrm{~s}^{-1}$ and a tube height of $10 \mathrm{~cm}$. The modeled flow deceleration of $56 \%$ corresponds well with measured reduction of flow velocity of around $60 \%$ (Friedrichs, 1997). The second case consists of a more recent flume experiment (Friedrichs et al., 2000 ), with a free stream velocity of $0.05 \mathrm{~m} \mathrm{~s}^{-1}$, a variation in the abundance of 490 to 3836 individuals $\mathrm{m}^{-2}$ and a tube height of $3.5 \mathrm{~cm}$. Due to the fact that the height of the bottom boundary layer $(\approx 3 \mathrm{~cm})$ was comparable to the height of the tubes, Friedrichs et al. (2000) discuss that the results may vary with different experimental settings, but that the results are qualitatively correct. Nevertheless, the reduction in the near bottom flow velocity modeled with a tube height of $10 \mathrm{~cm}$ and a free stream velocity of $0.05 \mathrm{~m} \mathrm{~s}^{-1}$ shows comparable results with the measured flow deceleration in the flume (Figure 5.3). Comparing these flume and model experiments is acceptable, while the 
population density and not tube length is the main determinant in the deceleration of the flow (Nowell and Church, 1979). Population densities used in the flume experiments are comparable to density distribution measured in the field for L. conchilega.

The flow deceleration by $L$. conchilega will reduce the ripple height both directly and indirectly, as observed in the field by Featherstone and Risk (1977). Directly, by a decrease in energy near the bed and indirectly due to deposition of fine particles in the tube fields and consequently lower ripples. Moreover, another indirect effect is the augmentation of the benthic community with the presence of $L$. conchilega (Rabaut et al., 2007). These ecosystem engineering species burrow and crawl through the top layer of the sediment and in this way break down the ripples. Reduction of the ripple height in the field is site specific (local sediment sorting, amount of suspended sediment and abundance of burrowing and crawling species), and therefore difficult to express in general terms. However, following the empirical relations derived by O'Donoghue et al. (2006), the ripple height will reduce to $60 \%$, given a reduction of the near bottom flow to $30 \%$ of the original near bottom flow velocity. A reduction of $70 \%$ of the bottom flow is chosen to represent the maximum density of $L$. conchilega found in the North Sea area (Borsje et al., 2009a; Chapter 4). Assuming a break down of the ripples by $10 \%$ due to the burrowing and crawling of the ecosystem engineering species, the maximum reduction of the ripple height is $70 \%\left(f_{\text {Lanice }, \text { stab }}=0.3\right)$.

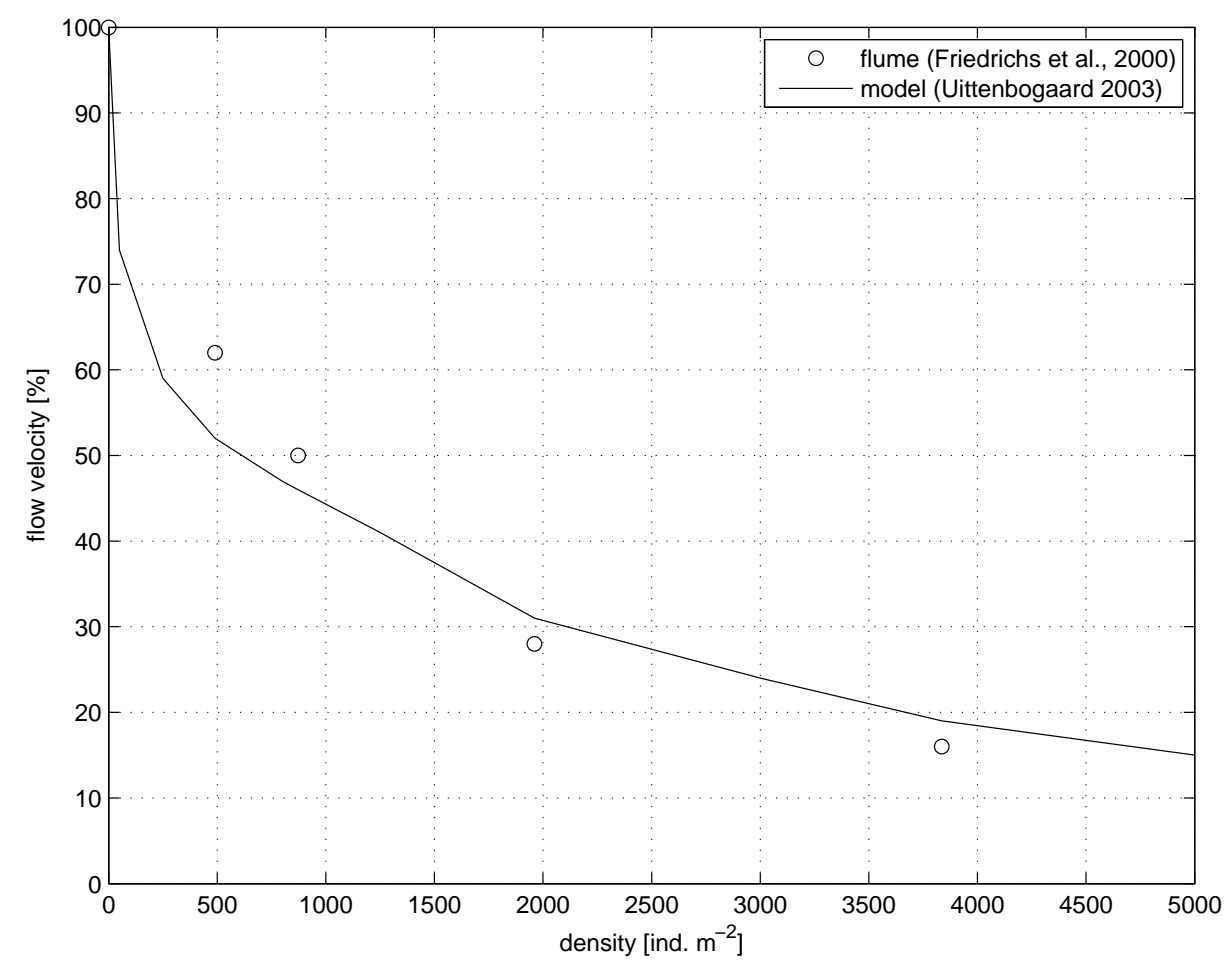

Figure 5.3: Comparison between the flow deceleration by Lanice conchilega for different densities, mimicked in a flume experiment by thin piles (Friedrichs et al., 2000) and model results, by adopting the vegetation model by Uittenbogaard (2003). Deceleration expressed as flow velocity in percent of reference velocity at $1.5 \mathrm{~cm}$ above the sediment surface. 


\subsubsection{Bivalve - Tellina fabula}

Data on the ecosystem engineering species capacity of the bivalve T. fabula are scarce, but the sediment modification by the bivalve Macoma balthica is much better known. Both bivalves have comparable feeding strategies (selective deposit as well as suspension feeding). However, M. balthica is mostly found in muddy sediments, while T. fabula prefers fine sand sediments. Therefore, the distribution of $M$. balthica is much more bordered close to the coast, in contrast to T. fabula which can be found in all other parts of the North Sea. Nevertheless, the relation used for M. balthica to parameterize the sediment destabilization is a good alternative to model the bio-sediment interactions for $T$. fabula. The biomass of the bivalve is related to the critical bed shear stress by a destabilizing factor $\left(f_{\text {Tellina,destab }}\right)$. The destabilizing factor is defined by Borsje et al. (2008a), based on field experiments by Austen et al. (1999), and quantitatively shown in Figure 5.4.

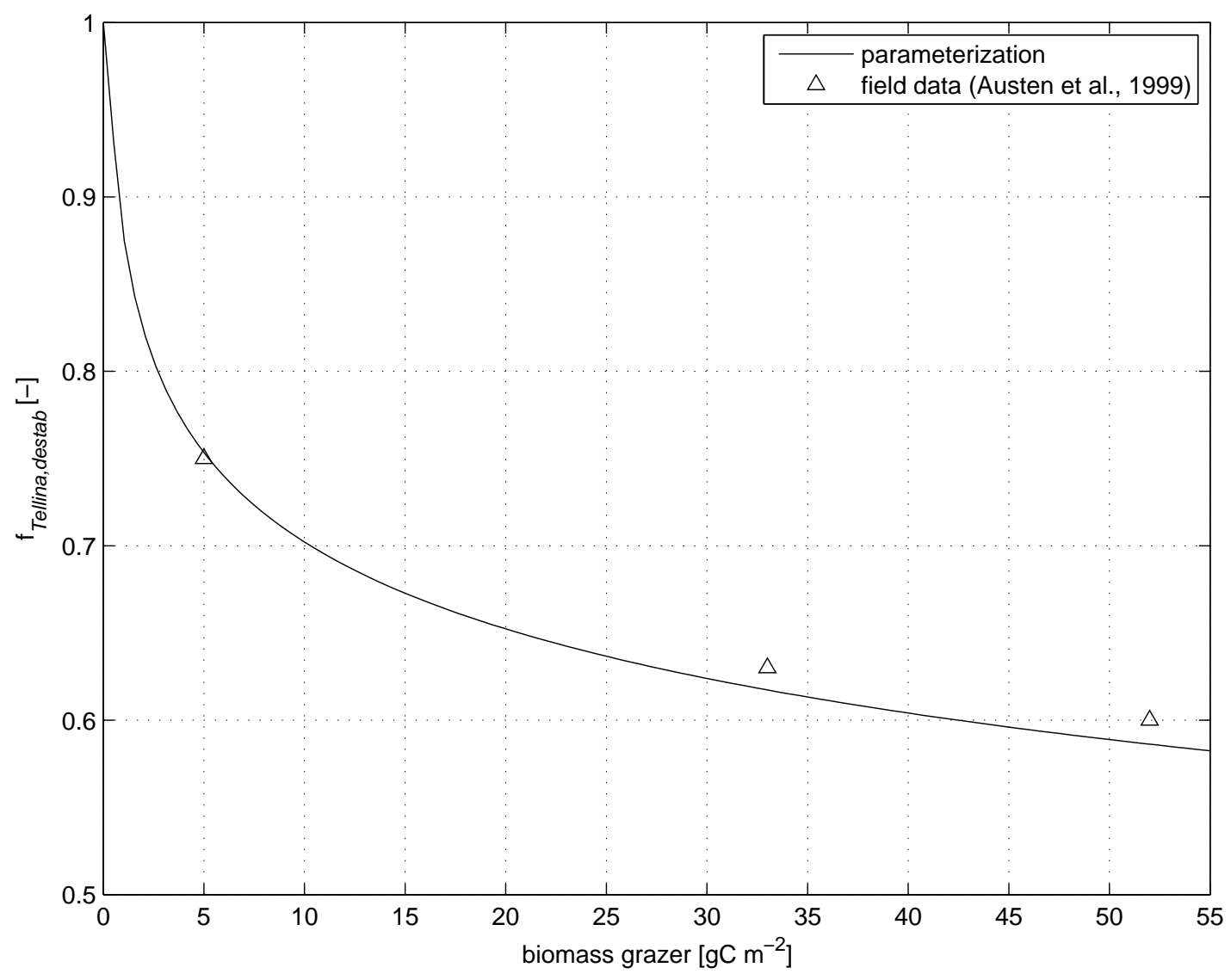

Figure 5.4: Destabilization of the bed by Tellina fabula, expressed in a destabilization factor $\left(f_{\text {Tellina,destab }}\right)$ on the critical bed shear stress, adapted from Borsje et al. (2008a). 


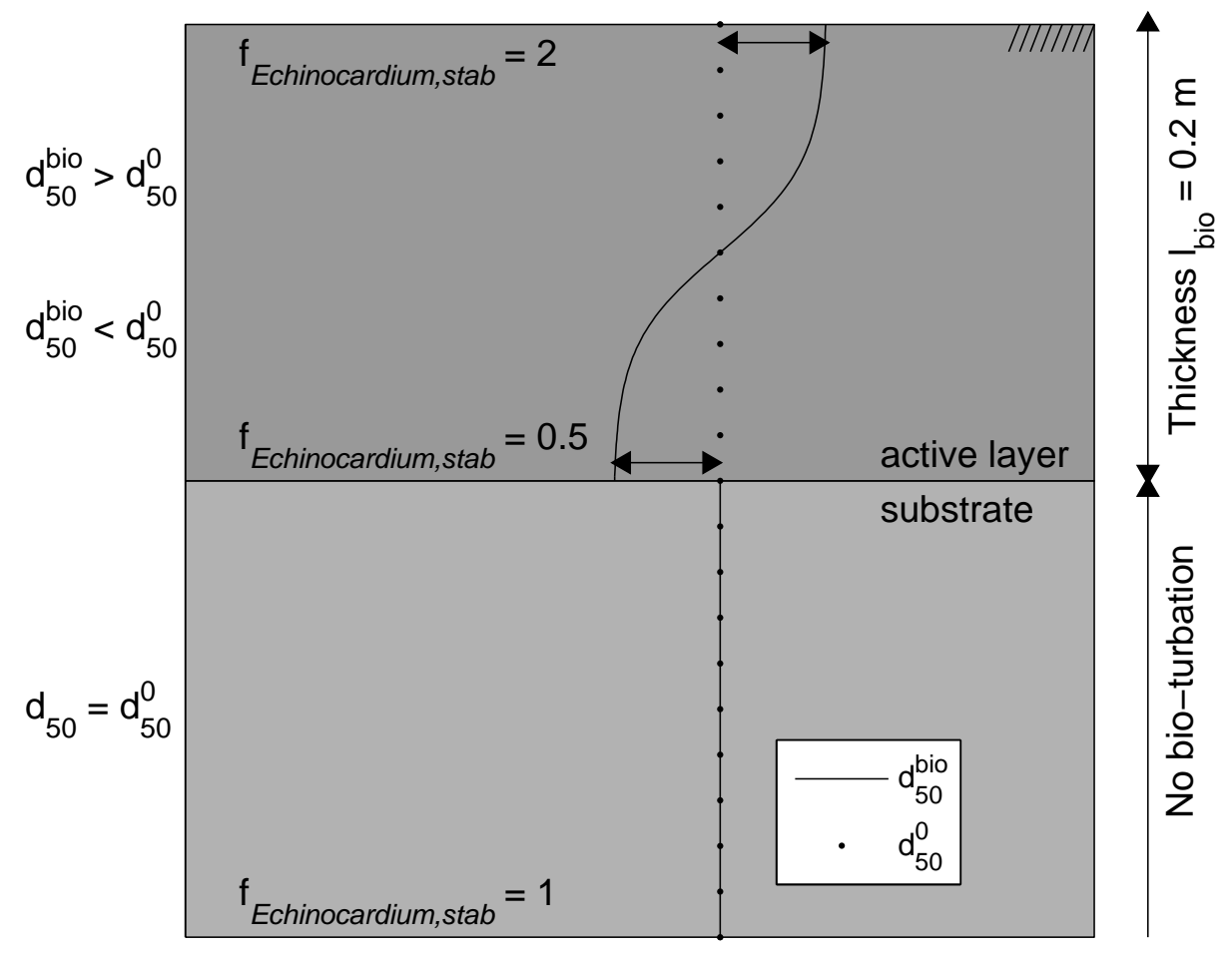

Figure 5.5: Schematic overview of the influence of Echinocardium cordatum on the grain size distribution in the bed. Resulting in a larger grain size in the surface layer and a smaller grain size in the subsurface layer $\left(d_{50}^{\text {bio }}\right)$, compared to the physical case $\left(d_{50}^{0}\right)$, expressed in a stabilization factor $\left(f_{\text {Echinocardium,stab }}\right)$. In the substrate, no bioturbation occurs.

\subsubsection{Sea urchin - Echinocardium cordatum}

E. cordatum causes a change in sediment distribution in the bed, resulting in a relatively coarser layer at the sediment water interface, and relatively finer layer of sediment underneath this layer. E. cordatum is regarded as a non-selective deposit feeder (Lohrer et al., 2005). However, fine particles which have a higher relative surface area and a higher organic content than coarse particles (Bureno et al., 2003) have a higher probability of being ingested and brought downward than coarse particles (Cramer et al., 1991). This causes the heterogeneous sediment distribution in the top centimeters of the bed. To parameterize the transport of particles from the sediment surface deeper into the sediment by E. cordatum, we adopt an active layer concept. In this concept, the probability of entrainment of a particle is defined in a step function, for which the probability of entrainment of a particle has a constant value in an active layer near the bed surface, and vanishes below this layer (Hirano, 1971). The layer underneath the active layer is called the substrate, which is physically covered by the active layer. As a result, the grain size distribution in both layers can be assigned differently. By adopting an active layer thickness which is equal to the area of influence by E. cordatum the 
top layer can be modeled as a bio-turbated layer, while the substrate can be modeled as a non bio-turbated layer. Based on an experimental study for E. cordatum in New Zealand, Lohrer et al. (2005) found that E. cordatum displaces up to $20,000 \mathrm{~cm}^{3} \mathrm{~m}^{-2}$ $\mathrm{d}^{-1}$, suggesting that surface sediment is reworked about every 3 days at sites where $E$. cordatum is abundant.

The heterogeneous vertical sediment distribution is shown in Figure 5.5, in which the thickness of the bio-turbated layer $\left(l_{b i o}\right)$ and the biological stabilization factor for the median grain size needs to be imposed. Based on measurements of Arenicola marina (Baumfalk, 1979), which is also a non-selective deposit feeder, the stabilization factor could reach values up to $2\left(f_{\text {Echinocardium,stab }}=2\right)$, meaning a median grain size twice as large, compared to the default case. The thickness of the bio-turbated layer could reach values up to $0.2 \mathrm{~m}$ (Holtmann et al., 1996).

\subsection{Modeling biogeomorphological interactions for offshore sand waves}

Hulscher (1996) was the first who showed that sand waves can be seen as instabilities of the coupled system (sediment dynamics and hydrodynamics). The interaction of the oscillatory tidal flow with sinusoidal bed perturbations gives rise to a tidally averaged residual flow, in the form of vertical re-circulating cells. If the net displacement of the sediment dragged by this resulting flow pattern is directed toward the crests, the amplitude of the perturbation grows. On the other hand, the perturbation decays if the net motion of the sediment is directed towards the troughs of the bed waviness, i.e. decreasing the amplitude.

The theoretical investigation of sand wave appearance forced by tidal motion has mainly been carried out by means of stability analyses. By applying a linear stability analysis to the coupled system, the wavelength and crest orientation with respect to the principal tidal current is determined. Such an analysis has the following steps. First, the basic state is selected, which represents a flat bed subject to a spatially uniform tidal flow. The second step is the introduction of small amplitude perturbations to the coupled systems and the determination of the growth rate of these perturbations individually. If all growth rates are negative, all bed patterns are damped and we define this as a bed on which no large-scale bed forms occurs. However, if at least one bed pattern has a positive growth rate, the flat bed is unstable and a wavy bed pattern occurs. The wavelength with the fastest growing mode is considered to represent the occurring sand wave. For a detailed explanation on the theory behind the use of linear stability analysis for understanding morphodynamic behavior of coastal systems see Dodd et al. (2003).

\subsubsection{Biogeomorphological model description}

The biogeomorphological model used in the present chapter is based on the work by Hulscher (1996) and later modified by Van der Veen et al. (2006), who developed a large-scale bed form prediction model that uses the parameters water depth, flow velocity and sediment grain size to give site-specific predictions for the type of bed form that occurs at a certain location. The biogeomorphological model is the result of the inclusion of the parameterization of biological processes in the model of Van der Veen (2006). In the model only bedload transport is modeled, since Hulscher (1996) 
assumed that this type of sediment transport is dominant in offshore tidal regimes. The transport equation reads:

$$
S_{b}=\alpha\left(\tau_{b}\right)^{b}\left(\frac{\tau_{b}}{\left|\tau_{b}\right|}-\lambda \nabla h\right) H e\left(1-\frac{\tau_{c r}}{\tau_{b}}\right),
$$

where $S_{b}$ is the volumetric sediment transport vector, $\alpha$ the bedload proportionality parameter, $b$ denotes the non-linearity of transport in relation with the bed shear stress, $\lambda$ is a bed-slope correction term, $h$ the height of the bed form, $\tau_{c r}$ the critical bed shear stress, $\tau_{b}$ is the bottom shear stress and the Heaviside function $\mathrm{He}$ is equal to zero for negative arguments and is equal to 1 for positive arguments. The bed shear stress according to Soulsby (1997) reads:

$$
\tau_{b}=\rho C_{d} u^{2}
$$

where $\rho$ is the density of seawater, $u=(u, v)$ is the velocity vector and $C_{d}$ is the drag coefficient, defined by:

$$
C_{d}=0.0415\left(\frac{Z_{0, s k i n}}{H}\right)^{\frac{2}{7}}
$$

Here, $H$ is the local water depth and $Z_{0, s k i n}$ is the level of zero intercept (the level above the seabed, where the flow velocity is zero) due to grain size only:

$$
Z_{0, \text { skin }}=\frac{d_{50}}{12}
$$

in which $d_{50}$ is the median grain size. In Equation 5.2 the critical bottom shear stress is imposed by:

$$
\tau_{c r}=\theta_{c r} g\left(\rho_{s}-\rho\right) d_{50},
$$

where $g$ is the gravitational acceleration, $\rho_{s}$ is the density of the sediment and $\theta_{c r}$ is the dimensional critical Shields parameter:

$$
\theta_{c r}=\frac{0.30}{1+1.2 D^{*}}+0.055\left(1-e^{-0.020 D^{*}}\right),
$$

where, $D^{*}$ is the dimensionless sediment parameter, prescribed by:

$$
D^{*}=d_{50} \frac{\Delta g^{\frac{1}{3}}}{\nu^{2}}
$$

where $\Delta$ is the relative density and $\nu$ is the kinematic viscosity of water. Water motion driven by the tide is described with the three-dimensional shallow water equations. The flow model and the sediment-transport model are coupled by:

$$
\frac{\partial h}{\partial t}+\frac{\partial S_{b}}{\partial x}+\frac{\partial S_{b}}{\partial y}=0 .
$$

Equation 5.9 simply states that convergence (or divergence) of the sediment flux must be accompanied by a rise (or fall) of the bed profile. The model can be solved, once the resistance parameter and the Stokes number are prescribed. Van der Veen et al. (2006) give expressions for both parameters, by fitting the partial slip model used in Hulscher (1996) to a more realistic turbulence model including a no-slip condition at 
the bed and a parabolic eddy viscosity (Hulscher and Roelvink, 1997). Among other parameters, in both expressions the parameter $z_{0}$ appears, which denotes the level above the seabed, where the flow velocity is zero, and reads (Soulsby, 1983):

$$
z_{0}=2 \Delta_{r}\left(\frac{\Delta_{r}}{\lambda_{r}}\right)^{1.4},
$$

in which (Van Rijn, 1993):

$$
\Delta_{r}=\alpha_{m r} H \quad \lambda_{r}=\beta_{m r} H,
$$

where $\alpha_{m r}=0.03$ and $\beta_{m r}=0.5$, denote dimensionless coefficients for the mega ripple regime in the North Sea (Tobias, 1989) and $\Delta_{r}$ and $\lambda_{r}$ are the mega ripple height and length, respectively. Based on the values of the resistance parameter and the Stokes number, Hulscher (1996) constructed a diagram in which four separate regions are discerned (flat bed, sandbanks, tide parallel ridges and sand waves). Following this diagram, we constructed a new diagram in which the appearance of sand waves is expressed in physical parameters (water depth, flow velocity and grain size; Figure 5.6). As a result, we can easily determine whether the model predicts the occurrence of sand waves at a certain location. The diagram is constructed for different grain sizes. Since smaller grain sizes have a smaller critical bed shear stress, the occurrence of sand waves for smaller grain sizes starts at lower energy levels (smaller water depth and smaller flow velocity).

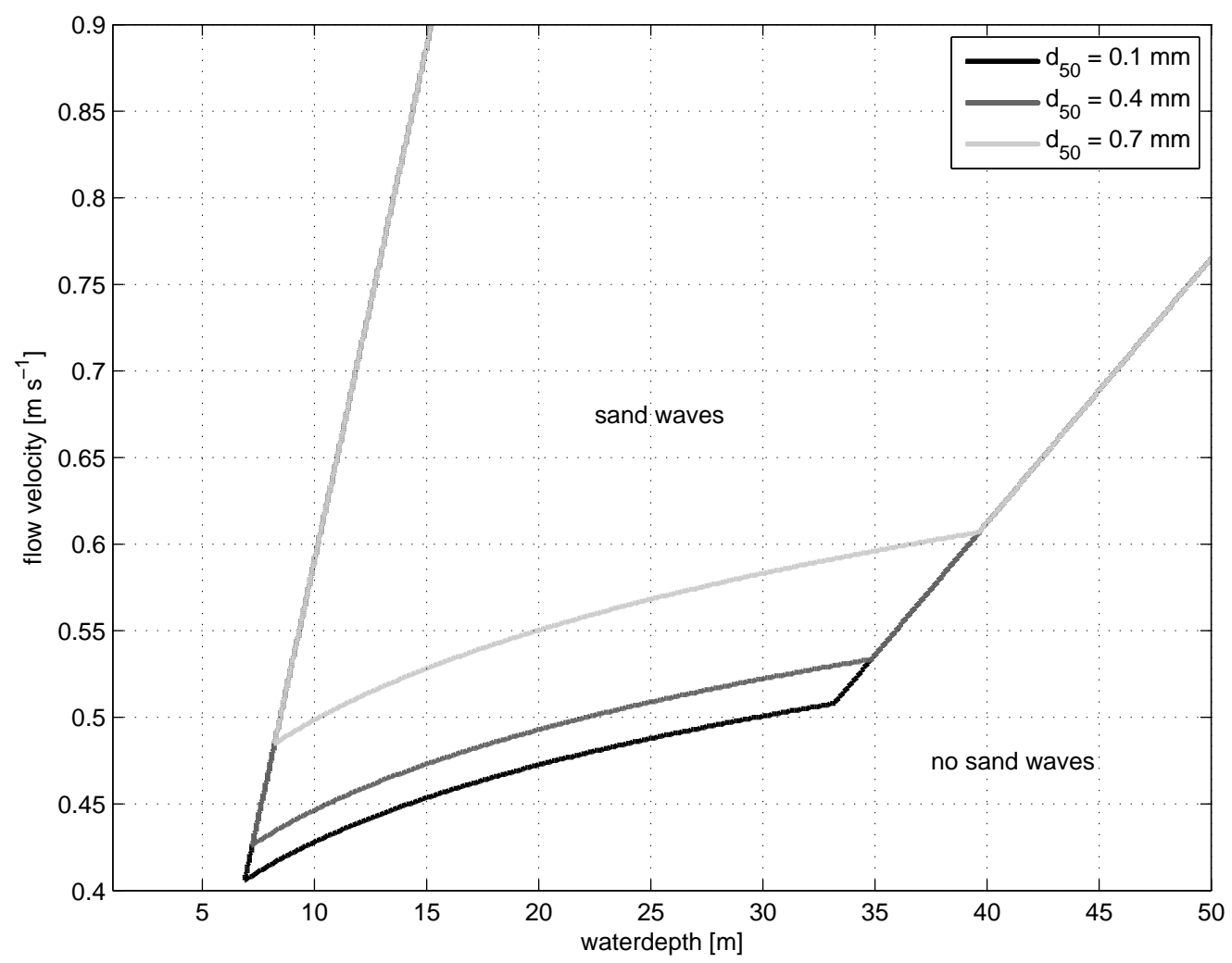

Figure 5.6: Diagram to predict the occurrence of sand waves for different water depth, flow velocity and grain size, modified after Hulscher (1996). 
The inclusion of the parameterization is done by adapting Equation 5.11 for Lanice conchilega, Equation 5.6 for Tellina fabula and Equations 5.5, 5.6 and 5.8 for Echinocardium cordatum, according to the relations presented in Section 5.2, which leads to the following expressions:

$$
\begin{gathered}
\Delta_{r}^{b i o}=\Delta_{r}^{0} f_{\text {Lanice }, \text { stab }}, \\
\theta_{c r}^{\text {bio }}=\theta_{c r}^{0} f_{\text {Tellina,destab }}, \\
d_{50}^{b i o}=d_{50}^{0} f_{\text {Echinocardium,stab }},
\end{gathered}
$$

where $f_{\text {Lanice,stab }}, f_{\text {Tellina,destab }}$ and $f_{\text {Echinocardium,stab }}$ are the (de)stabilizing biological factor for the ripple height, critical bed shear stress and grain size, respectively. Again, the superscript ' 0 ' for the ripple height, critical bed shear stress and grain size represent the values without the influence of biological activity (default).
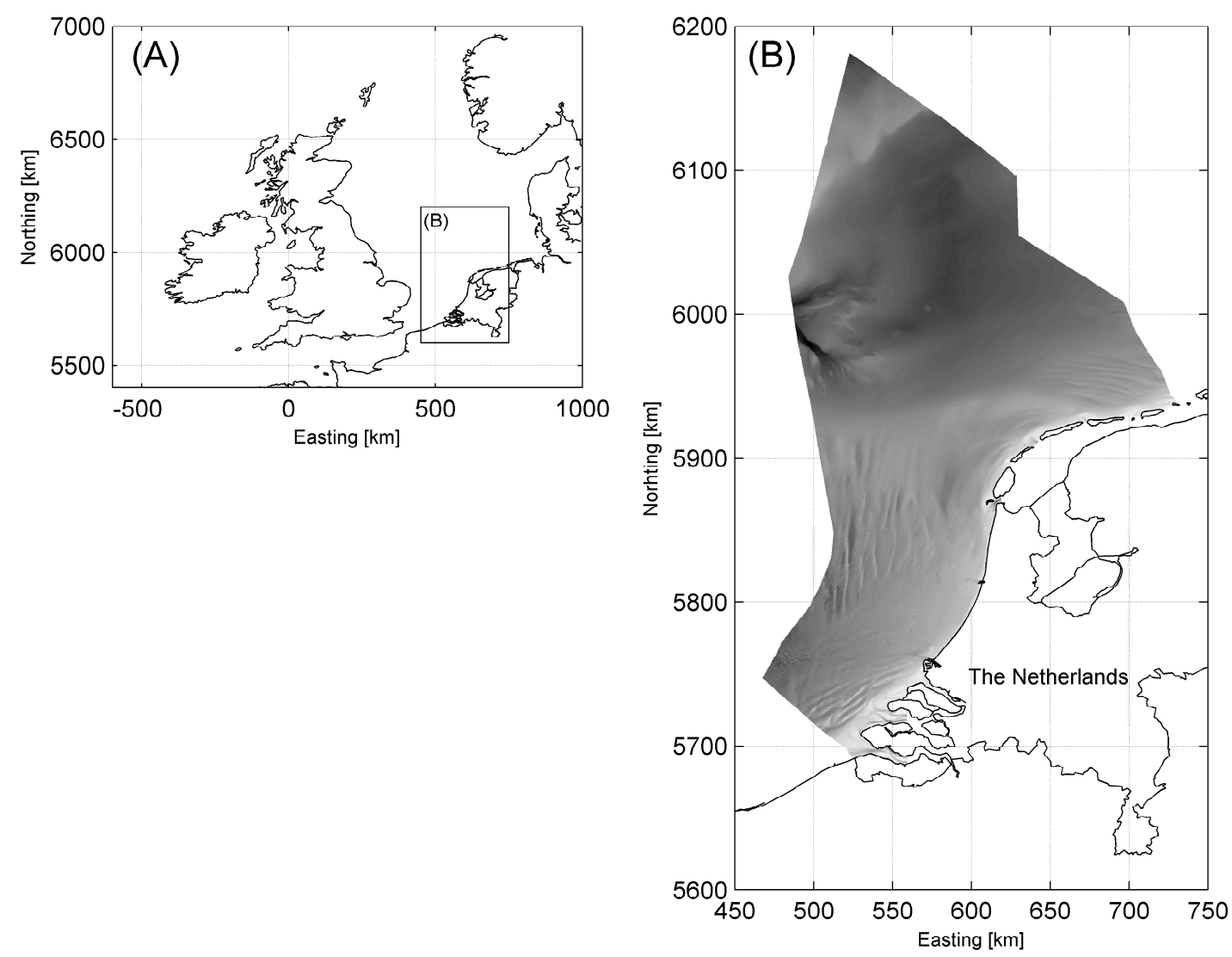

Figure 5.7: Overview of the bathymetry of the Dutch part of the North Sea. Water depths are up to $70 \mathrm{~m}$. 


\subsubsection{Study area}

The Dutch part of the North Sea shows a wide range of large-scale bed patterns (Figure 5.7). Shoreface-connected ridges are the largest bed forms in the study area. These ridges are with an oblique angle connected to the lower shoreface. Wavelength is in the order of kilometers and the amplitude of these bedforms is smaller than 3 meters (Van de Meene and Van Rijn, 2000). The dimensions of tidal sandbanks are comparable to the dimensions of shoreface-connected ridges, although tidal sandbanks widely occur in the offshore part of the North Sea and are not only bounded close to the coast (Dyer and Huntley, 1999). The spatial scale of sand waves is smaller than that of shorefaceconnected ridges and sandbanks. The typical wavelength of sand waves is between 100-800 m, and their amplitude is of the order of $5 \mathrm{~m}$ (Tobias, 1989). Sand waves have the shortest response time of all bedforms described above. Katoh et al. (1998) showed that sand waves regenerate in several years time. Therefore, we focus in this study on sand waves, because the biological time scale is also assumed to comprise several years (e.g. Barrio Froján et al., 2008).

The spatial distribution of the three ecosystem engineering species is extremely scattered (Holtmann et al., 1996). Therefore, in this study we will focus on the contours of high densities of the three species (Figure 5.8).
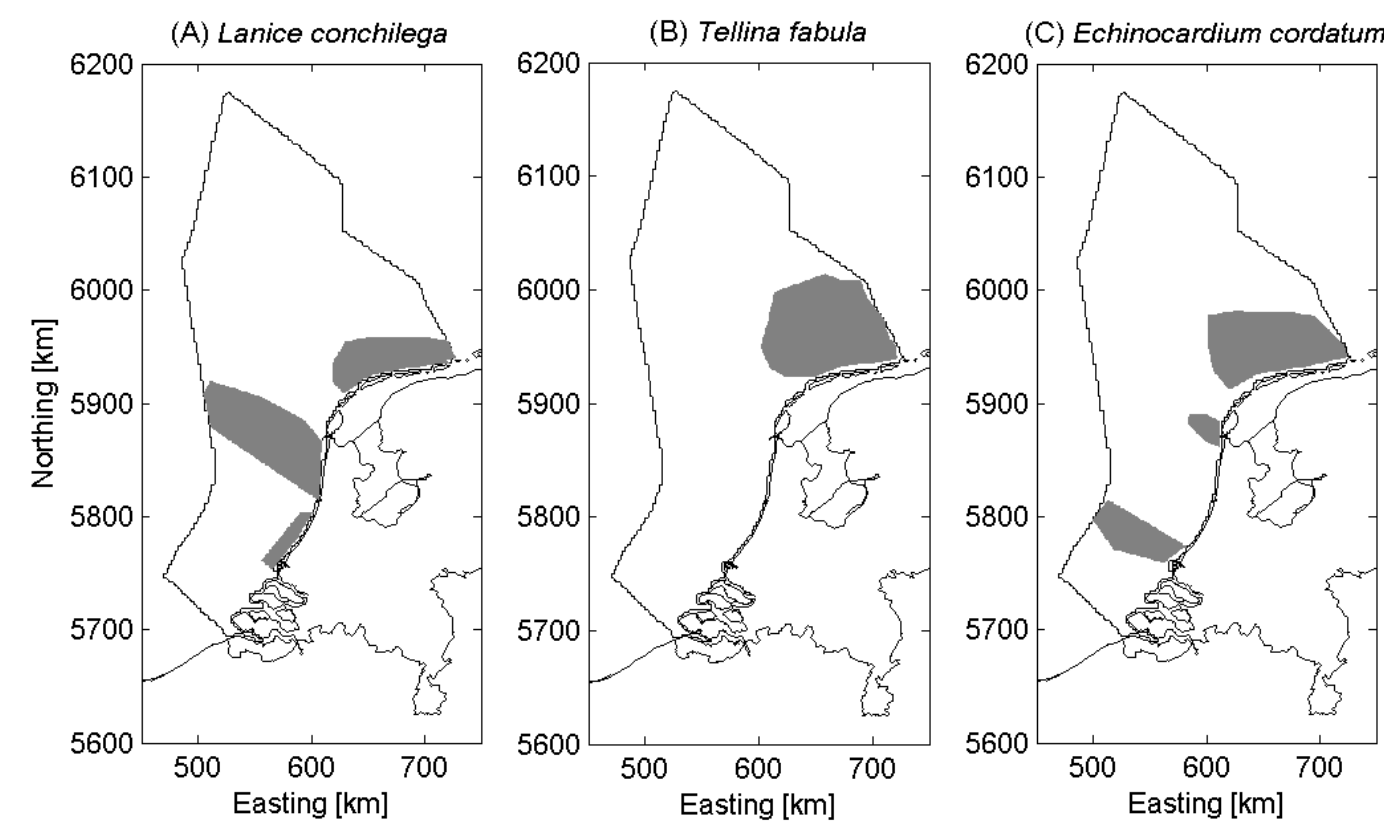

Figure 5.8: Contours of high densities of Lanice conchilega (A), Tellina fabula (B), and Echinocardium cordatum (C) on the bed of the Dutch part of the North Sea. Data adapted from Holtmann et al. (1996). 
(A) Lanice conchilega

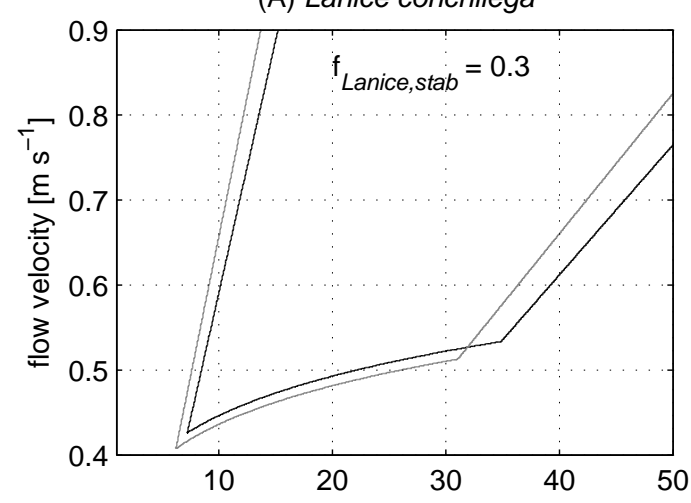

(C) Echinocardium cordatum

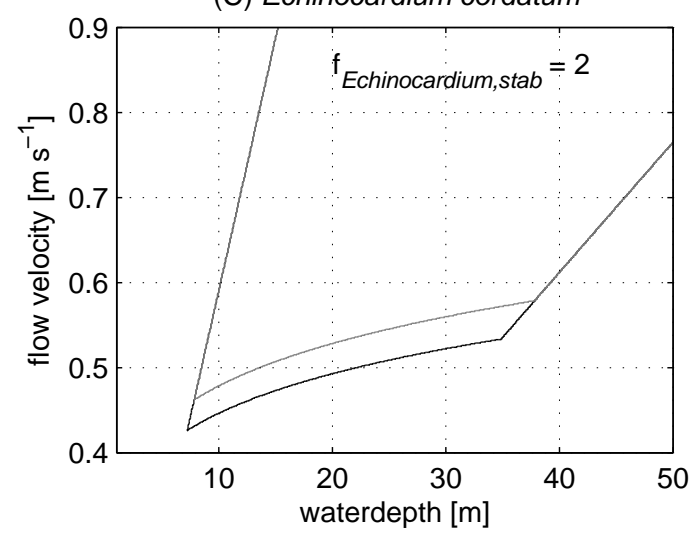

(B) Tellina fabula

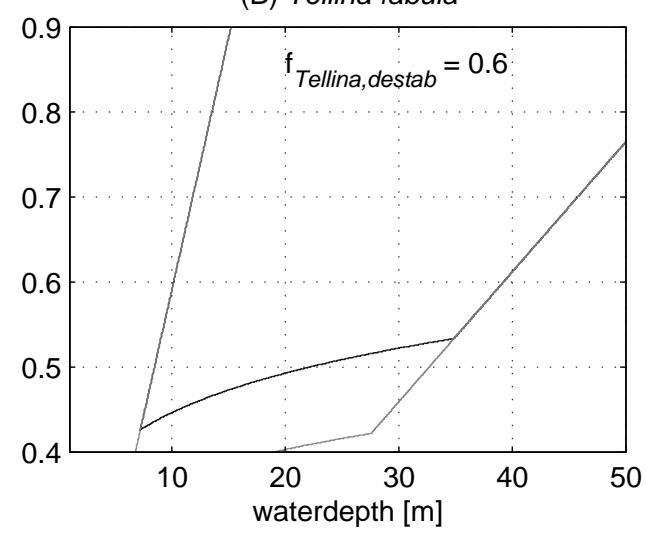

Figure 5.9: Adaptation of the prediction diagram (black line) for Lanice conchilega (A), Tellina fabula (B), and Echinocardium cordatum (C), following Eqs. 5.12, 5.13, and 5.14. Median grain size in the absence of biological activity is $0.4 \mathrm{~mm}$.
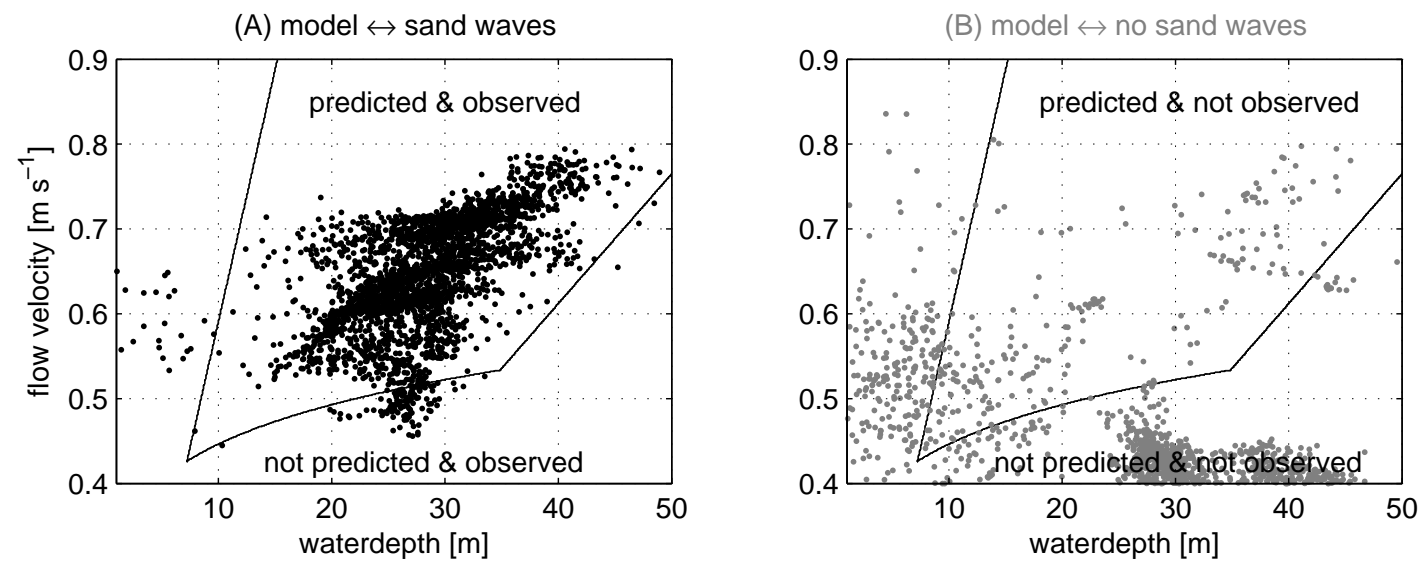

Figure 5.10: Comparison between model prediction (line) and field data (black points are sand wave locations (A); gray points are locations without sand waves (B)) of the occurrence of sand waves without the inclusion of biological activity (data adapted from Hulscher and van den Brink, 2001). 


\subsubsection{Results}

By including the maximum adaptation of the process parameters by biological activity in the model, the area in which sand waves occur is influenced for the three different ecosystem engineering species (Figure 5.9). Since E. cordatum increases the grain size at the sediment water interface, the area for which sand waves are predicted decreases, due to the increase of the critical bed shear stress (Equation 5.6), as already shown in Figure 5.6 for different grain sizes. For the same reason, the area of the occurrence of sand waves for $T$. fabula is increased, due to a decrease in critical bed shear stress. L. conchilega is able to decrease the ripple height, and consequently the level of zero intercept (Equation 5.10). Hulscher and van den Brink (2001) discussed that a decrease in the level of zero intercept will result in a decrease in the area with no model prediction. This results in the occurrence of sand waves at smaller water depths and smaller flow velocities. However, by decreasing the level of zero intercept, also the occurrence of sandbanks is triggered for moderate water depths and flow velocities, resulting in a reduction of the area of occurrence of sand waves.

To validate the proposed parameterization, we compare field data of the occurrence of sand waves adapted from Hulscher and Van den Brink (2001) with model predictions. Data on grain size, water depth and flow velocity are taken from Borsje et al. (2009a; Chapter 4). First, we compare the model results for the case in which no biological activity is included in the model (Figure 5.10). The observed sand waves are reasonably predicted by the model (Figure 5.10A). However, the model results also show a large over-prediction for places where sand waves are predicted and not observed (Figure $5.10 \mathrm{~B})$.

By including the areas where the three ecosystem engineering species are abundant in the model (Figure 5.8), the prediction of the occurrence of sand waves is changed (Figure 5.11; compare A and B). The case in which both sand waves are predicted by the model and observed in the field, is not much influenced by the included biological activity. However, the quite large over-prediction (column predicted AND not observed; Figure 5.12) in the model of Van der Veen et al. (2006) is partly restricted by $L$. conchilega and E. cordatum. Both stabilizing species are able to preserve a flat bed for almost $4000 \mathrm{~km}^{2}$ in the Dutch part of the North, while the physical parameters suggest sand waves. T. fabula destabilize the sediment, and therefore initiates the transport of sediment at lower energy levels, compared to the physical case. As a result, T. fabula is able to decrease the column in which sand waves are not predicted by the model, but observed in the field (Figure 5.12; column not predicted AND observed). However, this column is quite small in the default model, and therefore the destabilizer $T$. fabula is less effective compared to the stabilizers L. conchilega and E. cordatum. Therefore, at places where all three ecosystem engineering species are abundant, the stabilizers $(L$. conchilega and E. cordatum) trigger a flat bed, despite the destabilizing effect of $T$. fabula.

Based on these model simulations, we conclude that ecosystem engineering species can influence the occurrence of sand waves significantly. 


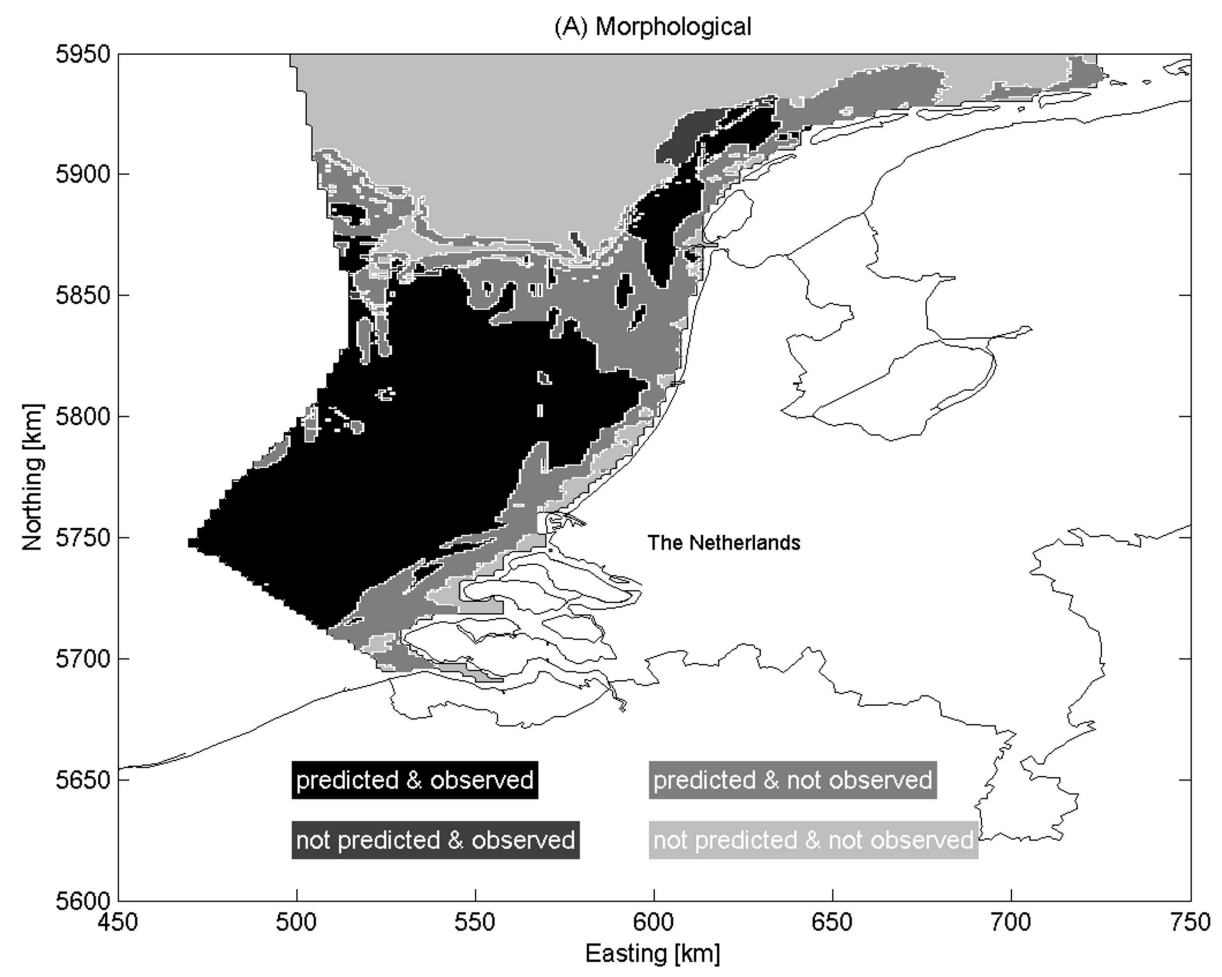

(B) Bio-geomorphological

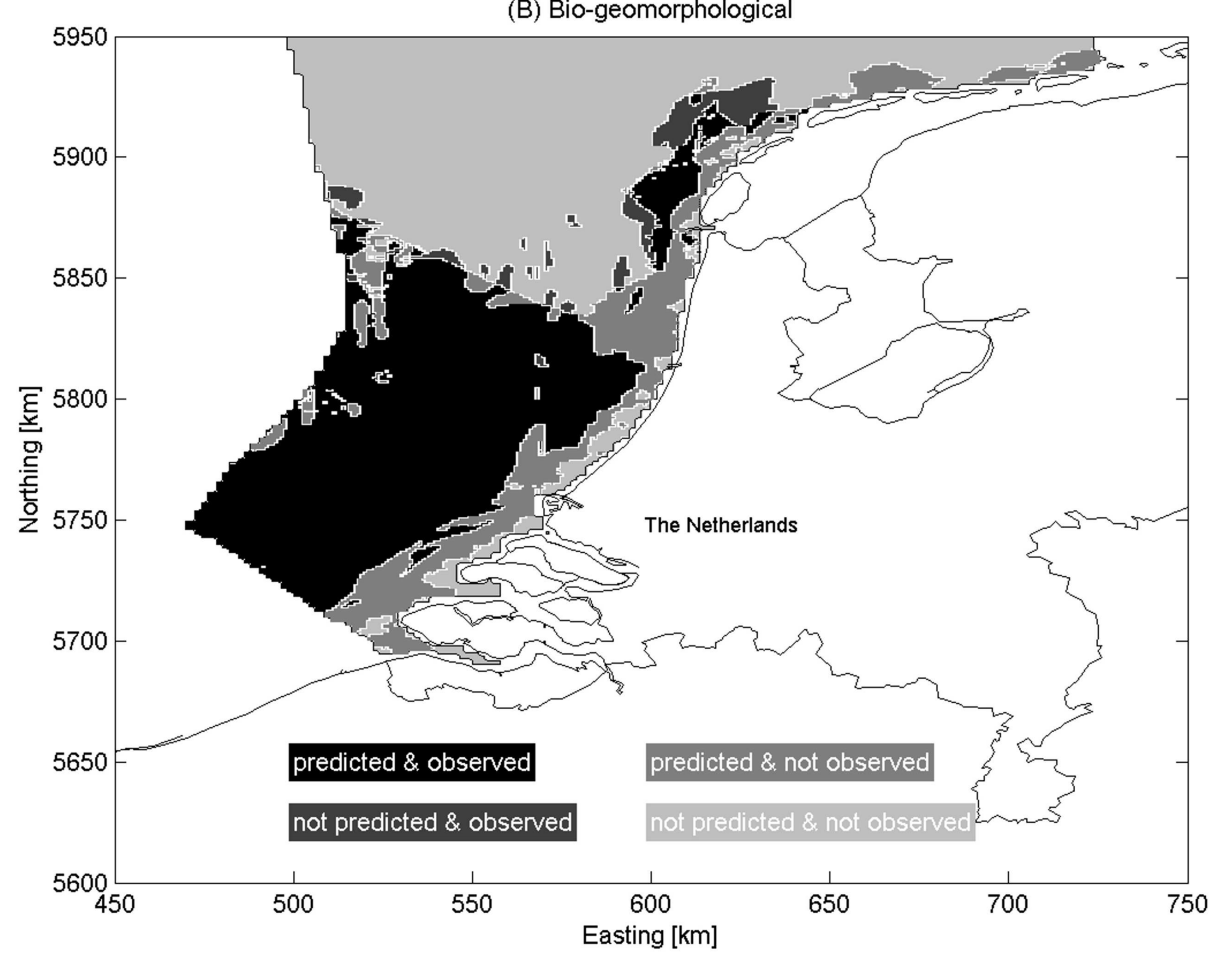

Figure 5.11: Spatial prediction of the occurrence of sand waves, both for the morphological case (A) and the biogeomorphological case (B). 


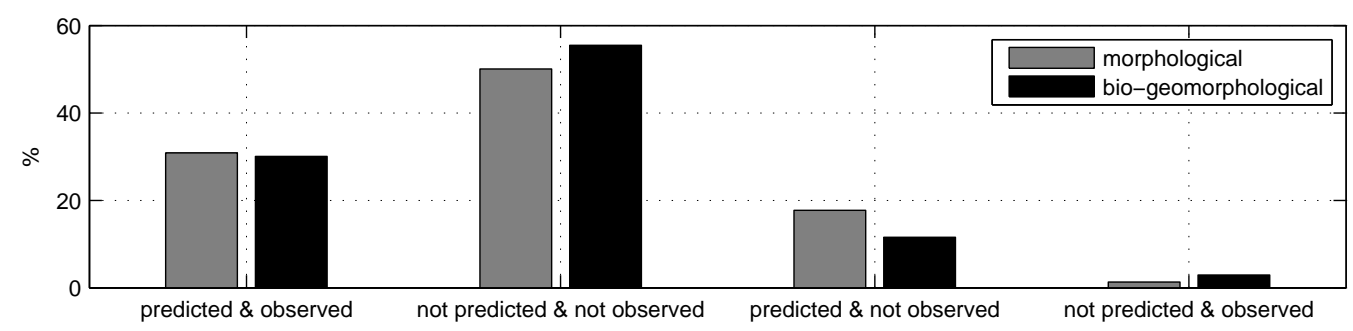

Figure 5.12: Results for the morphological case and biogeomorphological case, evaluated against observed sand wave occurrence in the Dutch part of the North Sea.

\subsection{Discussion}

This chapter proposes a parameterization on the interaction between benthos on the one hand and sediment dynamics and hydrodynamics on the other hand. Validation of the parameterization is executed with field data on the occurrence of sand waves from the Dutch part of the North Sea. The aim of this chapter is not to predict the occurrence of sand waves exactly. Therefore, we first need more site specific data of the biomass of ecosystem engineering species at a certain location. In this chapter we only included the biological activity of the parameterized benthos at locations where the ecosystem engineering species are abundant. Only the dominant influence of the three ecosystem engineering species on the sediment dynamics and hydrodynamics found in literature are included in the parameterization of the biological activity. Among the modification of the ripple height, critical bed shear stress and grain size distribution by L. conchilega, T. fabula, and E. cordatum respectively, also other transport parameters might be influenced. New insights can easily be included in the current parameterization, following the suggestion given in Equation 5.2.

The prediction of sand waves near the coast is still over-predicted (Figuur 5.11B). Among local biological activity, also the stabilizing effect of suspended sediment (Besio et al., 2006) may contribute to the absence of sand waves at these nearshore locations. Moreover, wind waves are not included in the model. Waves are considered to act as a stirring mechanism for sediment, such that the suspended sediment concentrations increase, especially near the coast, where the water depth is limited and in this way may influence the dimensions of sand waves. The model used in this chapter, has recently been extended by different authors (Besio et al., 2006; Németh et al., 2007). Subsequently, it is now also possible to model the dimensions (wave height and wave length) and migration of sand waves. However, in the present chapter we focus on the occurrence of sand waves mainly. The model of Van der Veen (2007) is sufficient for that purpose. Future developments will focus on the impact of benthos on the dimensions and migration speed of sand waves by including the proposed parameterization in the recently developed models. A further important challenge for the future will be to include the effects of temporal variation in benthic biomass on sediment dynamics and hydrodynamics. A fully coupled biological-physical approach would also necessitate the parameterization of the effect of change in sediment dynamics and hydrodynamics on biological activity. In this way we are able to couple the biological and morphological system. By combining the habitat suitability studies of Degraer et al. (2008) with the parameterization proposed in this study, a first insight can be given in the feedback from the change in sedimentary processes to the change in biological activity. 


\subsection{Conclusions}

This chapter proposes a parameterization on the interaction between three subtidal benthic species on the one hand and sediment dynamics and hydrodynamics on the other hand. By including this parameterization in an idealized sand wave model, the occurrence of sand waves is significantly better predicted, compared to the default case. In summary, stabilizing benthos are able to preserve a stable flat bed, while the physical conditions suggest bed patterns. Likewise the opposite effect is induced by destabilizing benthos.

In reality, many more benthic species are present in the North Sea, with a much more variable and finer-grained spatial distribution than modeled in this chapter. Moreover the temporal variation at seasonal and year-to-year scales needs to be accounted for when extending the models to predict seabed dynamics. However, the inclusion of the three most relevant ecosystem engineering species in the North Sea already shows the necessity to account for biogeomorphological interactions in predicting sand wave occurrence in shallow shelf seas. 


\title{
Chapter 6
}

\section{Creation and degradation rates of biogeomorphological structures: a study on the tube-building polychaete Lanice conchilega}

\section{This chapter is based on the paper:}

B.W. Borsje, T.J. Bouma, M. Rabaut, P.M.J. Herman, S.J.M.H. Hulscher. Creation and degradation rates of biogeomorphological structures: a model study on the tubebuilding polychaete Lanice conchilega, under review.

\begin{abstract}
In this chapter we study how organism traits of ecosystem engineering species in combination with environmental forcing affect the creation and degradation rates of biogeomorphological structures. As example of an ecosystem engineering species, we study the widely distributed marine tube-building polychaete Lanice conchilega, which live in patches that form 10-80 cm tall mounds in soft-bottom sediments. We modeled the tube-building worms as thin solid piles that affect drag and turbulence, and thereby the local sediment and thus mound dynamics. With respect to the hydrodynamics, model predictions showed good agreement with flume experiments for flow velocity adaptations both outside and within a patch of tube-building worms. The modeled equilibrium mound height increased with the organism trait 'tube length', and with population density, but was only little affected by strength of the tidal current. In all cases, the modeled mound heights remained within the range of field observations. Finally, the model outcome showed that the degradation rate of the mound after recruitment failure is comparable to the creation rate, suggesting a sort of 'legacy' that can serve as a juvenile trap and hence aid in regenerating a degrading mound.
\end{abstract}




\subsection{Introduction}

There is a growing recognition of the importance of feedbacks between organisms and physical forces in landscape formation, which is generally referred to as biogeomorphology (Corenblit et al., 2008; Murray et al., 2008; Reinhardt et al., 2010). Biogeomorphological processes shape a broad range of landscapes, ranging from aeolian dunes (Baas and Nield, 2007) and alluvial floodplain rivers (Murray and Paola, 2003; Tal and Paola, 2007) to tidal marshes (D'Alpaos et al., 2007; Kirwan and Murray, 2007; Temmerman et al., 2007). Biogeomorphological processes typically involve so-called ecosystem engineering species, which are organisms that modify the abiotic environment via their physical structures or activity (Jones et al., 1994). Since the introduction of the concept, ecologists have studied a broad range of aspects that are affected by ecosystem engineering species (Jones et al., 1997; Jones et al., 2010). However, in contrast to geomorphologists who typically focus on the balance between formation and decay processes, ecologists have only recently started to emphasize the importance of the persistence of structures created by ecosystem engineering species (Hastings et al., 2007; Jones et al., 2010; Jones, 2012). In addition to that, both in the field of ecology and geomorphology, little attention has been given to how organism traits (Bouma et al., 2005; 2010; Peralta et al., 2008) and density (Bouma et al., 2007; van Hulzen et al., 2007; Widdows and Brinsley, 2002) of ecosystem engineering species affect biogeomorphological landscape formation. As a result, there is currently a general lack of knowledge on how organism traits of ecosystem engineering species in combination with environmental forcing affect the creation and degradation rates of biogeomorphological structures and landscapes.

Intertidal and subtidal estuarine and coastal ecosystems offer an ideal system to study how the dynamics of biogeomorphological structures are affected by organism traits of ecosystem engineering species. Not only a broad range of ecosystem engineering species interact with hydrodynamics (Widdows and Brinsley, 2002), but also the range of physical forcing that these organisms may encounter is wide (Herman et al., 2001; Degraer et al., 2003). Moreover, the recent progress made in modeling biogeomorphological interactions using process-based hydrodynamic models (e.g. Le Hir et al., 2007; Borsje et al., 2008a; Orvain et al., 2012) allows in-depth study of these systems. The main biogeomorphological interactions in these ecosystems involve the stabilizing or destabilizing of the sediment by biological activity, which can modify sediment fluxes by a factor 2 and more, compared to the purely physical case (Graf and Rosenberg, 1997; Widdows and Brinsley, 2002).

In our study we focus on the widely distributed tube-building worm Lanice conchilega, as a model species. L. conchilega is an ecosystem engineering species that lives in patches and creates rigid tubes that protrude from the sediment $(1-4 \mathrm{~cm})$, whereas the main part of the species body remains hidden in the seabed (Ziegelmeister, 1952). Albeit small, these tubes directly influence the near bed water flow and thereby the sediment dynamics (Eckman et al., 1981). Flume studies (Friedrichs et al., 2000; Friedrichs and Graf, 2009; Friedrichs et al. 2009) have shown that - depending on current velocities - tube densities as low as $5 \%$ coverage cause sediment stabilization by skimming flow, whereas at lower tube densities erosion may be enhanced by enhanced turbulence. Field studies have shown that patches of L. conchilega indeed raise the sea bed by sediment trapping in between the protruding tubes (Figure 6.1). By extending the tubes after sedimentation, L. conchilega mounds can reach a height of 10 to $80 \mathrm{~cm}$ 


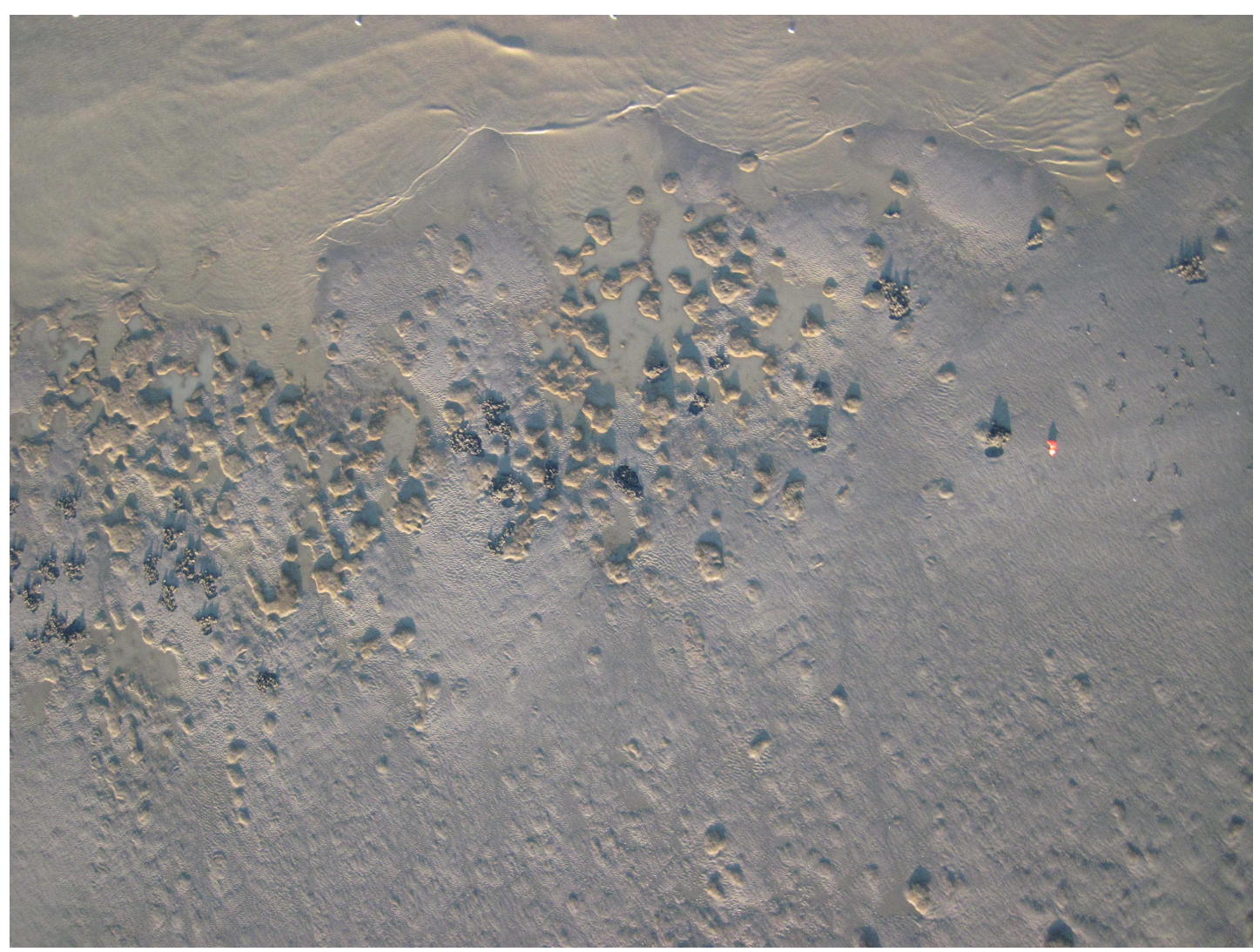

Figure 6.1: Kite Aerial Photography (KAP). Aerial picture of intertidal area with Lanice conchilega reefs. Total area is around $100 \times 100 \mathrm{~m}$. Picture taken with camera Canon D10 attached to a kite type Flow Form 4. Intertidal area of Boulogne-sur-mer during spring low tide: 14 October 2011. Picture under copyright. Picture courtesy: Dr. Klaas Pauly and Dr. Marijn Rabaut - Ghent University.

above the surrounding seabed (Carey, 1987; Degraer et al., 2008; Rabaut et al., 2009). In contrast to the flume studies, field observations show mound presence for coverage densities even smaller than 5\% (Rabaut et al., 2009).

Recently, the effect of tube-building worms has been included in large-scale geomorphological models, showing that the small-scale stabilizing effect of dense patches of tube-building worms can affect the large scale sediment transport (Bobertz et al., 2009; Borsje et al., 2009a; Chapter 4). However, as these studies use simplified empirical relations between the density of tube-building worms and their effect on sediment dynamics, they cannot reproduce the typical mound formation by L. conchilega.

In this study, we aim to provide a mechanistic understanding of the creation and degradation rates and the equilibrium height of the L. conchilega mounds, by elucidating how these characteristics depend on tube length, an organism trait, and on population density and physical forcing. We will do this by using a numerical shallow water model (Delft3D) extended with a module which accounts for the influence of rigid cylindrical structures on drag and turbulence (Dijkstra and Uittenbogaard, 2010). This Delft3D model enables us to explicitly account for the interactions among the tubes, the hydrodynamics and the sediment dynamics.

We validated the model against flume measurements on the flow adaptation both 
within and outside a $L$. conchilega patch, since the gradient in sediment transport rate induced by the flow determines the geomorphological changes. Published flume experiments only quantified the flow adaptation within a patch of $L$. conchilega mimics (Friedrichs et al., 2000; Friedrichs and Graf, 2009). In a new flume experiment we demonstrated the flow adaptation outside a patch of $L$. conchilega mimics with varying tube density. After validating the model for hydrodynamics, we applied the model to study (i) the flow adaptation within and outside a patch of tube-building worms for a wide range of population densities, (ii) the mound formation rate and mound equilibrium height by sediment trapping in relation to the biological (tube length and population density) and physical (flow velocity amplitude, water depth, grain size) factors and (iii) the degradation rate of the mound. The main findings of the model results are discussed with a focus on the role of ecosystem engineering species in landscape formation.

\subsection{Material and Methods}

\subsubsection{Flume experiments for model validation}

Data on flow velocity variations within a patch of $L$. conchilega mimics with varying tube density were obtained from Friedrichs et al. (2000). In their flume experiment the water depth was kept constant at $20 \mathrm{~cm}$ and the flow velocity was set at $0.05 \mathrm{~m}$ $\mathrm{s}^{-1}$. The artificial tubes were $5 \mathrm{~cm}$ in length, $0.5 \mathrm{~cm}$ in diameter and protruded $3.5 \mathrm{~cm}$ into the water column. The tubes had a regular distribution within the patch, and the flow deceleration within the tube field was measured for four different tube densities: 3836, 1961, 872 and 490 individuals per square meter (ind. $\mathrm{m}^{-2}$ ). First, the flume experiment was run without tubes to obtain a reference flow velocity at $z=1.5 \mathrm{~cm}$ above the bed. Next, the flow velocity for the different tube densities was measured at $z=1.5 \mathrm{~cm}$ above the bed at different positions within the patch. The flow deceleration was than expressed in percent of the reference velocity.

Flow velocity variations outside a patch of $L$. conchilega mimics with varying tube densities $\left(3264,2448\right.$ and 1632 ind. $\left.\mathrm{m}^{-2}\right)$ were measured in a large racetrack flume at NIOZ-Yerseke. The flume consists of an oval channel ( $0.6 \mathrm{~m}$ wide) with a total length of $17.5 \mathrm{~m}$, a straight working section of $10.8 \mathrm{~m}$ and a total volume of about $9 \mathrm{~m}^{3}$. For further details on the racetrack flume see Bouma et al. (2005). During the experiment, the water depth was maintained at $0.2 \mathrm{~m}$ and a free stream velocity of $0.25 \mathrm{~m} \mathrm{~s}^{-1}$ was generated by a conveyor belt system, acting as a paddle wheel. Flow measurements were carried out with a Nortek acoustic doppler velocimeter (ADV) set to operate at a rate of $10 \mathrm{~Hz}$. The ADV was mounted on a computerized 3D positioning system, which was mounted on a carriage that could be placed anywhere along the length of the working section.

In the test section of the flume ( $2 \mathrm{~m}$ long, $0.6 \mathrm{~m}$ wide) we placed $7 \mathrm{~cm}$ long rigid drinking straws $(0.5 \mathrm{~cm}$ diameter) from which $3.5 \mathrm{~cm}$ length protruded into the water column (cf. Friedrichs et al., 2000). The patch size of the straws was $0.6 \mathrm{~m}$ in width and $0.49 \mathrm{~m}$ in length. In order to construct an even but non-regular distribution, a grid was placed with a mesh size of $3.5 \times 3.5 \mathrm{~cm}$ on the bed of the flume. Within every mesh of the grid 4 straws with a different color were placed randomly. This resulted in an even distribution at a scale $>3.5 \mathrm{~cm}$, but with random inter-individual distances at the smaller scale. By removing one color from the patch the tube density of the 
patch was reduced, but still evenly and non-regularly distributed over the area. The spatial layout of the straws was based on field observations, whereas previous flume studies used a regular distribution with fixed distances between straws (Friedrichs et al., 2000; Friedrichs and Graf, 2009; Friedrichs et al., 2009). Horizontal velocities were measured at three positions $(30 \mathrm{~cm}, 15 \mathrm{~cm}$ and $0 \mathrm{~cm}$ before the leading edge) and at three different heights $(z=2 \mathrm{~cm}, z=5 \mathrm{~cm}$ and $z=10 \mathrm{~cm})$ above the bed.

\subsubsection{Model set-up}

The formation of mounds by tube-building worms is modeled using the numerical shallow water model Delft3D-FLOW (Deltares, 2012). The system of equations consists of horizontal momentum equations, a continuity equation, a turbulence closure model, a sediment transport equation, an advection-diffusion transport equation and a sediment continuity equation. In the model both bedload and suspended load transport is included. For details on the model equations, see Lesser et al. (2004). The Delft3DFLOW model contains a module which explicitly accounts for the influence of cylindrical structures on drag and turbulence by an extra source term of friction force in the momentum equation and an extra source term of Total Kinetic Energy (TKE) and turbulent energy dissipation in the turbulence closure model. Details on the equations and the calibration tests of this module are given by Temmerman et al. (2005) and Dijkstra and Uittenbogaard (2010).

Two different model set-ups are used: one to validate the flume experiments and one to simulate field conditions. The former is set-up in a 2DV mode, i.e. considering flow and variation in $x$ and $z$ direction only, while assuming zero flow and uniformity in $y$ direction and the latter in $3 \mathrm{D}$, i.e. considering flow and variation in $x, y$ and $z$ direction.

The model domain of the 2DV model is 60 meters, with a constant horizontal resolution of $0.15 \mathrm{~m}$ (400 horizontal grid cells). In the vertical, the model grid is composed of 100 layers, with small vertical grid steps near the bed and increasing towards the water surface. At the upstream boundary a flow velocity is imposed, while at the downstream boundary a water depth is imposed of $H=0.2 \mathrm{~m}$. The bottom roughness height $k_{s}=7 \cdot 10^{-4} \mathrm{~m}$, following Bouma et al. (2007). In the centre of the model domain vertical rigid cylinders were defined over a section of $2.5 \mathrm{~m}$, each with a tube diameter $d_{\text {tube }}=0.5 \mathrm{~cm}$, a tube length $L_{\text {tube }}=3.5 \mathrm{~cm}$ and a tube density varying between $D_{\text {tube }}=100$ and $D_{\text {tube }}=5000$ ind. $\mathrm{m}^{-2}$. In order to compare the model results with the new flume experiments, the unidirectional flow velocity was set at $U_{\text {uni }}=0.25$ $\mathrm{m} \mathrm{s}^{-1}$, while the unidirectional flow velocity was set at $U_{u n i}=0.05 \mathrm{~m} \mathrm{~s}^{-1}$ to compare the model results with the flume experiment executed by Friedrichs et al. (2000). The model domain of the 3D model is 50 meters $\times 50$ meters, with a variable horizontal resolution of $0.33 \times 0.33 \mathrm{~m}$ in the centre of the domain increasing towards $1 \times 1 \mathrm{~m}$ near the lateral boundaries (4900 horizontal grid cells). In the vertical, the model grid is composed of 20 layers, with small vertical steps near the bed and increasing towards the water surface. At the lateral boundaries, a so-called Riemann boundary condition is imposed (Verboom and Slob, 1984). For this type of boundary condition, outgoing waves are allowed to cross the open boundary without being reflected back into the computational domain. The default water depth $H=2 \mathrm{~m}$ and the roughness height $k_{s}=6 \cdot 10^{-3} \mathrm{~m}$ represent a typical field condition (Bouma et al., 2007; Degraer et al., 2008). In the centre of the model domain vertical rigid cylinders were defined over a section of $2 \times 2 \mathrm{~m}$, each with a diameter of $d_{\text {tube }}=0.5 \mathrm{~cm}$ and a length of $L_{\text {tube }}=3.5$ 
Table 6.1: Parameter settings for the hydrodynamic model simulations: inside the patch, outside the patch and landscape scale.

\begin{tabular}{lllll}
\hline & Symbol [unit] & Inside & Outside & Landscape scale \\
\hline Figure & & 6.2 & 6.3 & 6.4 \\
\hline Flow velocity & $U_{\text {uni }}\left[\mathrm{m} \mathrm{s}^{-1}\right]$ & 0.05 & 0.25 & 0.25 \\
Water depth & $H[\mathrm{~m}]$ & 0.2 & 0.2 & 2 \\
Roughness height & $k_{s}[\mathrm{~m}]$ & $7 \cdot 10^{-4}$ & $7 \cdot 10^{-4}$ & $6 \cdot 10^{-3}$ \\
Tube diameter & $d_{\text {tube }}[\mathrm{cm}]$ & 0.5 & 0.5 & 0.5 \\
Tube length & $L_{\text {tube }}[\mathrm{cm}]$ & $2.0,3.5$ & 3.5 & 3.5 \\
Tube density & $D_{\text {tube }}\left[\mathrm{ind} \mathrm{m}^{-2}\right]$ & 490,872, & 1632,2448, & 500, \\
& & 1961,3836 & 3264 & 5000 \\
\hline
\end{tabular}

$\mathrm{cm}$. The area of the patch reflects typical field conditions (Degraer et al., 2008).

In order to show the impact of tubes on the hydrodynamics, first the model is forced with a flow velocity of $U_{u n i}=0.25 \mathrm{~m} \mathrm{~s}^{-1}$, a grain size of $d=0.2 \mathrm{~mm}$ and a tube density of $D_{\text {tube }}=500$ ind. $\mathrm{m}^{-2}$ and $D_{\text {tube }}=5000$ ind $\mathrm{m}^{-2}$ and not allowing for geomorphological changes. Next, the model was run for a semi-diurnal tide with a period of 12.5 hours, depth averaged flow velocity amplitude of $U_{M 2}=0.50 \mathrm{~m} \mathrm{~s}^{-1}$, a tube density varying between $D_{\text {tube }}=50$ and $D_{\text {tube }}=5000$ ind. $\mathrm{m}^{-2}$ and allowing for geomorphological changes, all corresponding to realistic field conditions (Rabaut et al., 2007; Verfaille et al., 2006; Degraer et al., 2008). Both a tube length of $L_{\text {tube }}=3.5 \mathrm{~cm}$ and $L_{\text {tube }}=2 \mathrm{~cm}$ is modeled. The former tube length corresponds to tube lengths used in the flume measurements. Since tube length is very variable in the field (Ziegelmeister, 1952), the latter tube length is used to demonstrate the influence of a variation in tube length on the mound height. Moreover, a geomorphological acceleration factor (MORFAC) of 60 is used to speed up the geomorphological changes (Deltares, 2012). By using a MORFAC of 60 the deposition and erosion fluxes are multiplied with a factor 60 during each time step. Consequently, one tidal period corresponds to 12.5 hours $* 60 \approx 1$ month of geomorphological changes. Smaller MORFAC values showed quantitatively the same results, however required longer simulation times. The model is run till an equilibrium mound height $h_{e q}$ is reached. The equilibrium mound height $h_{e q}$ is reached when the morphological changes are smaller than $1 \%$ of the actual mound height. The time to reach the equilibrium mound height is defined as the equilibrium time $T_{e q}$. Next, the sensitivity in equilibrium mound height $h_{e q}$ and equilibrium time $T_{e q}$ is investigated for a variation in physical factors (flow velocity amplitude $U_{M 2}$, water depth $H$ and grain size $d$ ), while keeping the tube length at $L_{\text {tube }}=2 \mathrm{~cm}$. Finally, the degradation of the mound is investigated. All parameter settings for the hydrodynamic and geomorphodynamic model simulations are listed in Table 6.1 and Table 6.2 respectively. Table 6.2 also specifies the reference run, which is used to compare the variation in model outcome due to a variation in biological and physical factors. 
(A) tube length $L_{\text {tube }}=3.5 \mathrm{~cm}$

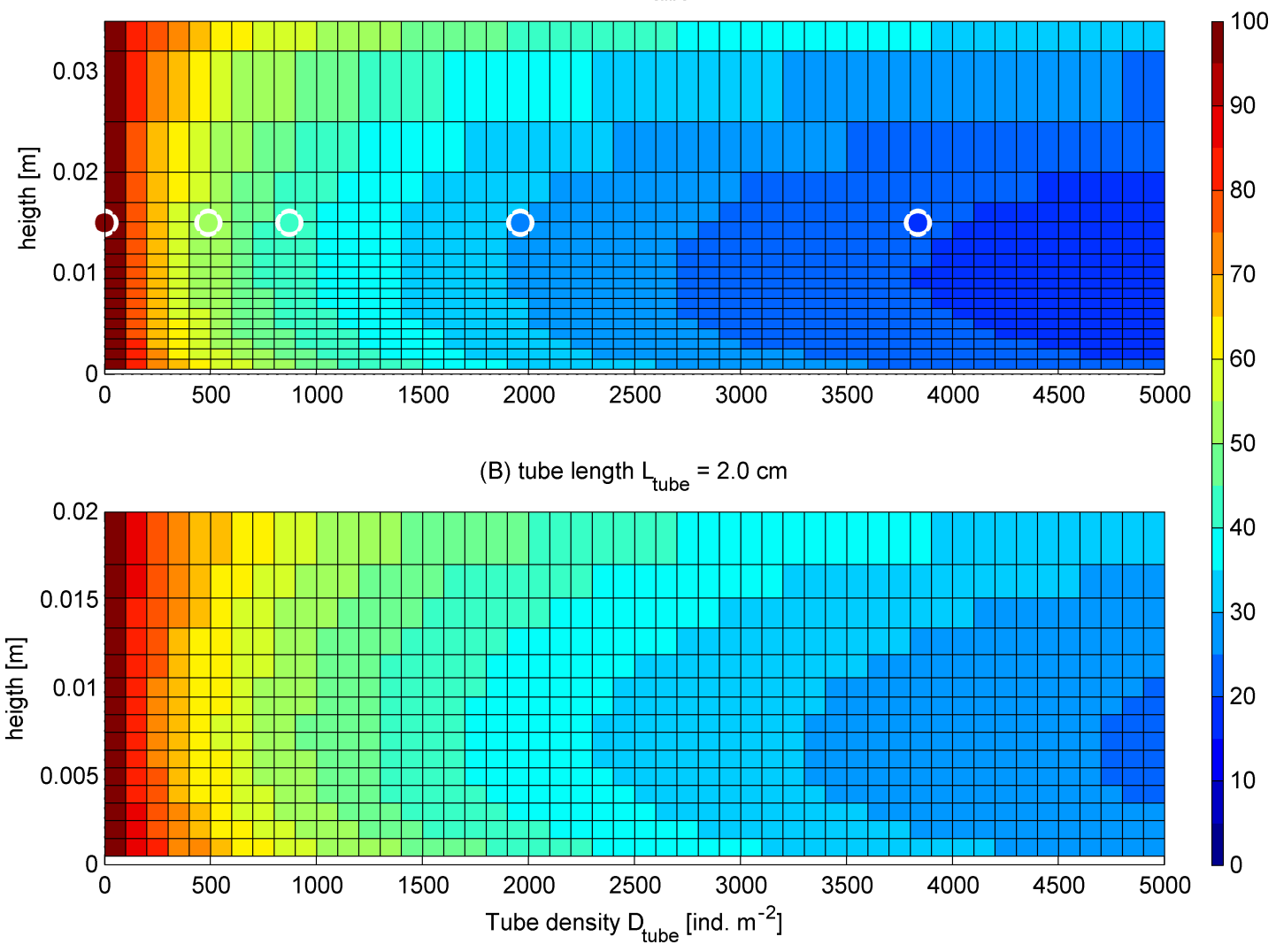

Figure 6.2: Relative flow velocity [\%] at the end of a $2.5 \mathrm{~m}$ long patch with a tube length $L_{\text {tube }}=3.5 \mathrm{~cm}(\mathrm{~A})$ and $L_{\text {tube }}=2.0 \mathrm{~cm}(\mathrm{~B})$. Results are given at different heights $[\mathrm{m}]$ above the sediment bed (Y-axis) and for increasing tube densities [ind. $\mathrm{m}^{-2}$ ] $\left(D_{\text {tube }}\right.$; $\mathrm{X}$-axis). Filled circles are flume measurements (Friedrichs et al., 2000) and colored area is model outcome. In both cases, flow velocity is expressed as percentage of a reference velocity over bare sediment, using a color scale from $0 \%$ (i.e., flow $=0 \mathrm{~m} \mathrm{~s}^{-1}$ ) to $100 \%$ (i.e., no flow deceleration) for visualization. 


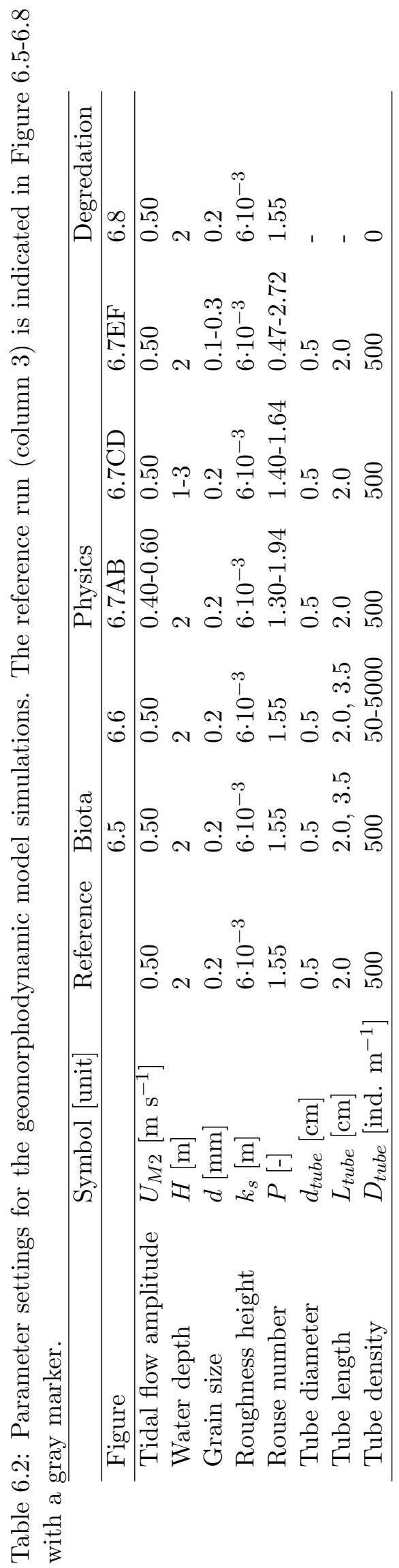




\subsubsection{Distinguishing the dominant transport mode by Rouse number}

Sediment is transported and modeled both as bedload and as suspended load. The Rouse number $P$ determines whether bedload or suspended load is the dominant transport regime for a given combination of flow velocity amplitude $U_{M 2}$, water depth $H$ and grain size $d$. The Rouse number $P$ is the ratio between the downward motion of the sediment by gravity and the upward motion by the turbulent water motion:

$$
P=\frac{w_{s}}{\kappa u_{*}},
$$

where $w_{s}$ is the settling velocity of the sediment, $\kappa$ is the von Karman constant (0.41) and $u_{*}$ is the shear velocity (for the equations see Van Rijn, 1993). Based on the Rouse number $P$, the dominant transport regime can be determined (Fredsøe and Deigaard, 1992):

suspended load transport $(P<1.2)$,

incipient suspended load transport $(1.2<P<2.5)$,

bedload transport $(P>2.5)$.

As will follow from the results section, it is important to know the dominant transport mode in order to understand the sensitivity in equilibrium mound height $h_{e q}$ and equilibrium time $T_{e q}$ of mound formation.

\subsection{Results}

\subsubsection{Hydrodynamic effects of patches - measurements \& modeling}

Comparison of our model results (Figure 6.2A: colored area) with flume observations by Friedrichs et al. (2000) (Figure 6.2A: filled circles) showed good agreement for the flow deceleration within a patch of tube-building worms. Modeling a range of tube densities showed that flow speed decreased fast with increasing tube density at low tube densities. For larger tube densities and a tube length of $L_{t u b e}=3.5 \mathrm{~cm}$ the flow deceleration reached a constant value of around $15 \%$ of the reference velocity (Figure $6.2 \mathrm{~A}$ ). For a tube length of $L_{\text {tube }}=2.0 \mathrm{~cm}$ and a tube density of $D_{\text {tube }}=5000$ ind. $\mathrm{m}^{-2}$ the flow deceleration reached a value of around $25 \%$ and was still decreasing with density (Figure 6.2B). The model showed that the flow deceleration is not uniform over the height; the maximum flow deceleration is between 0.5 and $1.5 \mathrm{~cm}$ above the bed.

There was also good agreement between the modeled (Figure 6.3: colored area) and measured (Figure 6.3: filled circles) hydrodynamic effects of the tube-building worms in front of the patch. Modeling a range of tube densities showed that both at $30 \mathrm{~cm}$ and $15 \mathrm{~cm}$ upstream of the patch, the flow velocities gradually increased near the bed (up to around $7 \mathrm{~cm}$ above the bed) for increasing tube density. However, at the leading edge (i.e., $0 \mathrm{~cm}$ in front of the patch) the flow velocity was strongly reduced near the bed and slightly underpredicted by the model for large densities. Higher in the water column (higher than around $7 \mathrm{~cm}$ above the bed), the opposite trend was observed: flow velocities decreased for increasing tube densities at $30 \mathrm{~cm}$ and $15 \mathrm{~cm}$ in front of the patch, whereas at the leading edge the flow velocities increased for increasing tube densities. The trend can be explained by the continuity of the water flow: decreasing 
flow velocities near the bed are compensated by increasing flow velocities higher in the water column and vice versa.

Subsequently, we modeled the impact of the tube-building worm patch on the largescale hydrodynamics for two different tube densities $\left(D_{\text {tube }}=500\right.$ ind. $\mathrm{m}^{-2}$ and $D_{\text {tube }}$ $=5000$ ind $\mathrm{m}^{-2}$ ) and a tube length $L_{t u b e}=3.5 \mathrm{~cm}$. The interaction between the patch and the environment clearly showed both a stabilizing and a destabilizing effect (i.e. a decrease and increase in bed shear stress respectively; Figure 6.4EF). As expected, the stabilizing and destabilizing effect was strongest for the highest tube density. For both tube densities, the flow within the patch was reduced as shown before (Figure 6.2). However, the flow over the patch was accelerated due to continuity, resulting in an uplift of water closely in front of the patch (Figure 6.4CD). This, in turn, caused an acceleration of horizontal flow just in front of the uplifting water (Figure 6.3AB). The result was an increase in bed shear stress in front of the patch and a reduction of the bed shear stress within the patch (Figure 6.4EF). In the wake zone of the patch the bed shear stress was also reduced over a long distance. Remarkably, for the high tube density patch the bed shear stress was constant within the patch (Figure 6.4F), whereas for the low tube density patch the bed shear stress decreased in the first tens of centimeters within the patch before reaching a constant value (Figure 6.4E). The

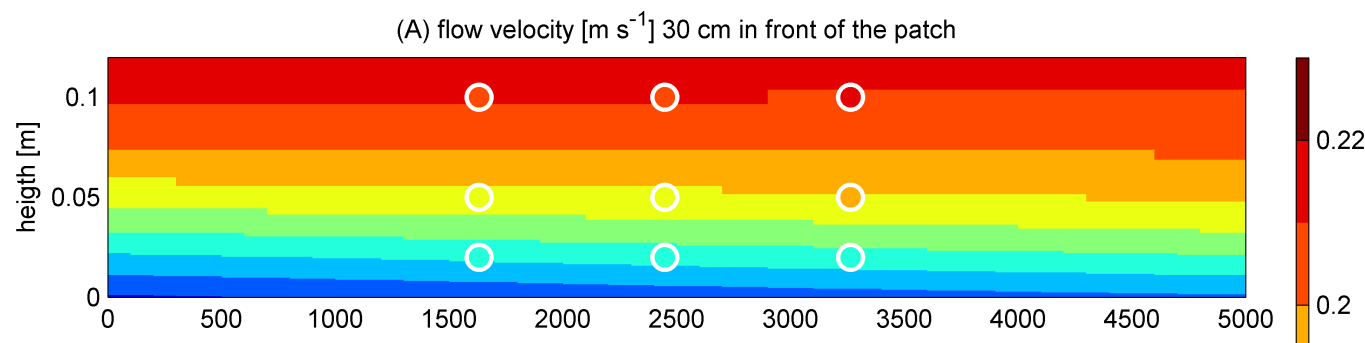

(B) flow velocity $\left[\mathrm{m} \mathrm{s}^{-1}\right] 15 \mathrm{~cm}$ in front of the patch

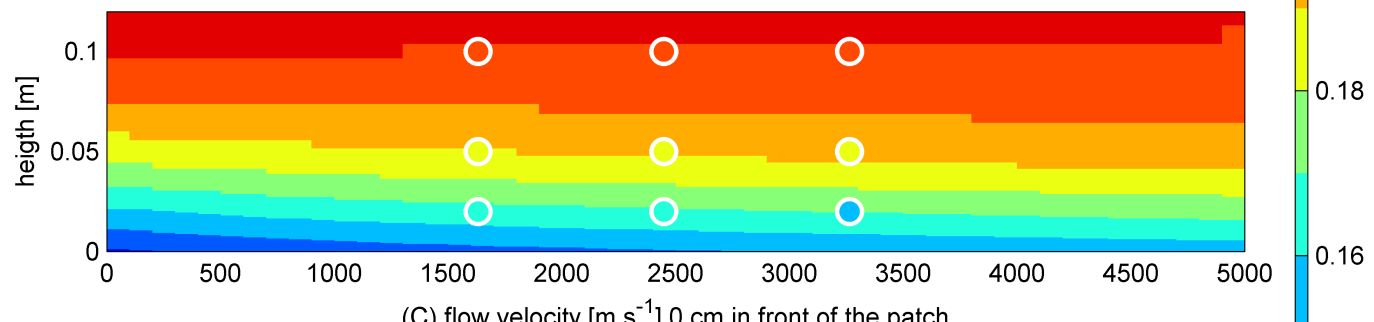

(C) flow velocity $\left[\mathrm{m} \mathrm{s}^{-1}\right] 0 \mathrm{~cm}$ in front of the patch

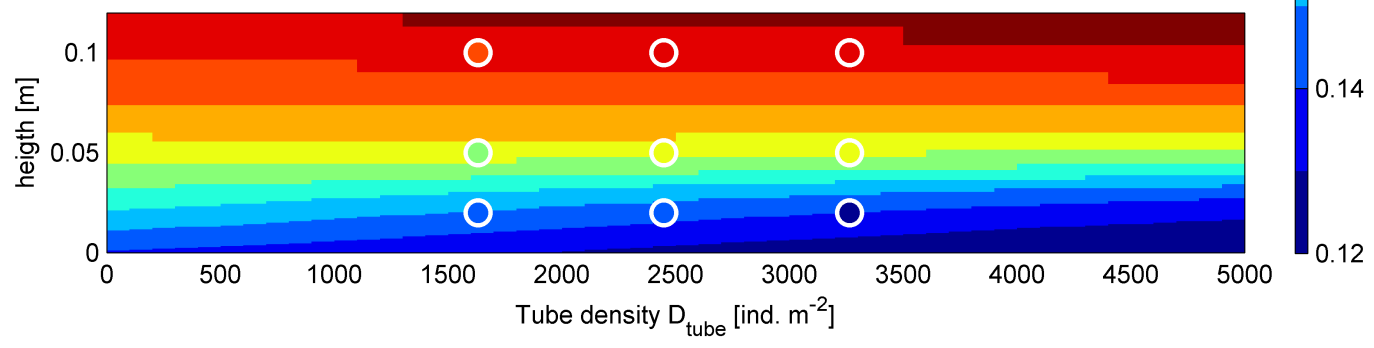

Figure 6.3: Flow velocity $\left[\mathrm{m} \mathrm{s}^{-1}\right]$ at $30 \mathrm{~cm}(\mathrm{a}), 15 \mathrm{~cm}(\mathrm{~B})$ and $0 \mathrm{~cm}(\mathrm{C})$ in front of a patch. Results are given at different heights $[\mathrm{m}]$ from the bed (Y-axis) and for increasing tube densities $D_{\text {tube }}$ [ind. $\mathrm{m}^{-2}$ ] (X-axis). Filled circles are flume measurements and colored area is model outcome. 

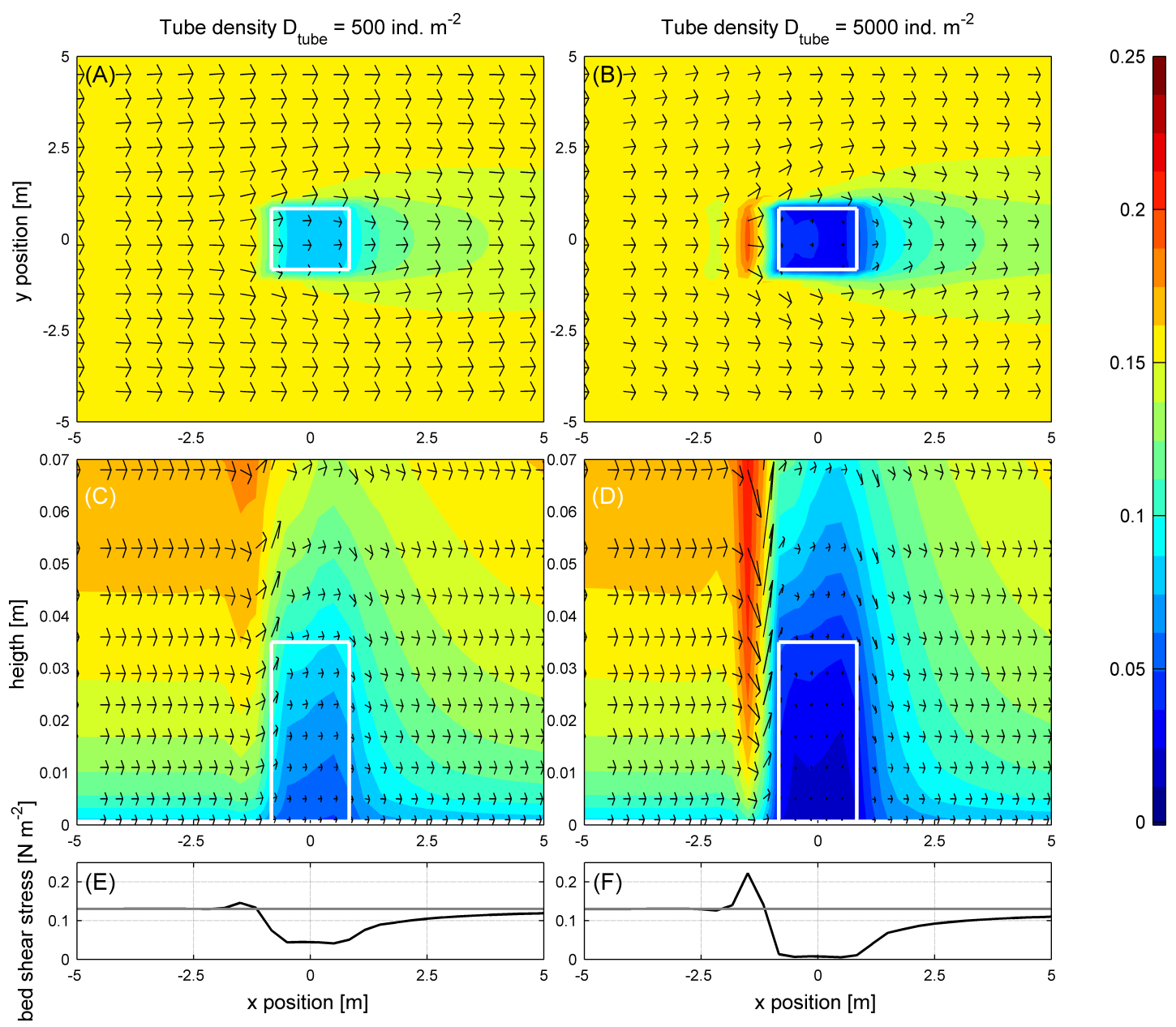

Figure 6.4: Interaction between a patch of $3.5 \mathrm{~cm}$ long tube-building worms (white box) and the environment, for a patch size of $2 \times 2 \mathrm{~m}$ and a tube density $D_{\text {tube }}=500$ ind. $\mathrm{m}^{-2}$ (left) and $D_{\text {tube }}=5000$ ind. $\mathrm{m}^{-2}$ (right). Top view of the horizontal flow velocity $u\left[\mathrm{~m} \mathrm{~s}^{-1}\right]$ at a height of $z=3.0 \mathrm{~cm}$ from the bed (AB), side view of the horizontal flow velocity $u\left[\mathrm{~m} \mathrm{~s}^{-1}\right]$ in the centre of the patch $(y=0 \mathrm{~m})(\mathrm{CD})$ and bed shear stress $\left[\mathrm{N} \mathrm{m}^{-2}\right]$ in the centre of the patch $(y=0 \mathrm{~m})(\mathrm{EF})$. Arrows indicate the flow velocity vector $(u, v)$ strength and angle $(\mathrm{AB})$ and flow velocity vector $(u, w)$ strength and angle (CD). For visualization purpose the cross-patch velocity component $v$ and vertical flow velocity component $w$ are multiplied with a factor 5 . 
flow was mostly deflected over the patch (Figure 6.4CD), and partly around the patch (Figure 6.4AB). Note the amplification factors used for visualization of the flow velocity vectors. In both simulations the maximum value of vertical velocity $w$ in front of the patch was around ten times larger than the maximum horizontal cross-patch velocity $v$ around the patch.

\subsubsection{Modeling geomorphodynamics of patches - biological factors}

Modeling the mound formation by tube-building worms of two contrasting tube lengths ( $L_{\text {tube }}=2.0 \mathrm{~cm}$ and $L_{\text {tube }}=3.5 \mathrm{~cm}$ ) showed that for both tube lengths the geomorphological changes were the largest in the first weeks, during which large amounts of sediment were deposited within the patch (Figure 6.5). However, due to the increase in bed level within the patch, the flow velocity also increased over and within the patch due to continuity of the water flow. Over time, the sediment transport rate on top of the mound equaled the sediment transport rate in front of the patch, so that an equilibrium mound height $h_{e q}$ was reached. The equilibrium time $T_{e q}$ to reach the equilibrium mound height $h_{e q}$ was almost twice as long for the longer tubes, compared to the smaller tubes (Figure 6.5). The equilibrium mound height $h_{e q}$ for the longer tubes was a factor 2.5 larger compared to the equilibrium mound height $h_{e q}$ for the smaller tubes (Figure 6.5). This is remarkable, as for a tube density of $D_{\text {tube }}=500$ ind. $\mathrm{m}^{-2}$ there was only $10 \%$ difference in flow deceleration between the longer tubes (i.e., $65 \%$ deceleration; Figure 6.2A) and the shorter tubes (i.e., 55\% deceleration; Figure 6.2B). This indicates that the relation between flow deceleration and geomorphodynamic changes is non-linear.

Next, we used the model to quantify how the equilibrium mound height $h_{e q}$ and equilibrium time $T_{e q}$ depended on tube density ( $D_{\text {tube }}$ from 50 to 5000 ind. $\mathrm{m}^{-2}$ ) for two contrasting tube lengths $\left(L_{\text {tube }}=2 \mathrm{~cm}\right.$ and $\left.L_{\text {tube }}=3.5 \mathrm{~cm}\right)$. As the gradient in flow deceleration was largest for small tube densities (Figure 6.2), the equilibrium mound height $h_{e q}$ and equilibrium time $T_{e q}$ also showed the largest variation for small tube densities (Figure 6.6). For high tube densities, the equilibrium mound height $h_{e q}$ hardly increased with further increasing tube densities, resulting in a maximum mound height for a given flow velocity amplitude $U_{M 2}$, water depth $H$ and grain size $d$. In this case, the maximum equilibrium mound height $h_{e q}=0.35 \mathrm{~m}$ and $h_{e q}=0.70 \mathrm{~m}$ for a tube length of $L_{t u b e}=2 \mathrm{~cm}$ and $L_{t u b e}=3.5 \mathrm{~cm}$, respectively.

\subsubsection{Modeling geomorphodynamics of patches - physical factors}

The model allowed us to quantify the sensitivity in equilibrium mound height $h_{e q}$ and equilibrium time $T_{e q}$ for a range of flow velocity amplitudes $U_{M 2}$, water depths $H$ and grain sizes $d$ (Figure 6.7), relative to a reference run (gray circle; Table 6.2). By increasing the flow velocity amplitude $U_{M 2}$, the equilibrium mound height $h_{e q}$ hardly changed (Figure 6.7A), since the flow deceleration within the patch was almost the same for the different flow velocity amplitudes. However, the equilibrium time $T_{e q}$ decreased for increasing flow velocity amplitude (Figure 6.7B), due to the increase in total transport rate. For increasing water depth $H$, the equilibrium mound height $h_{e q}$ increased (Figure 6.7C), because the flow acceleration on top of the patch becomes smaller, causing lower sediment transport rates within the patch. Consequently, also the equilibrium time $T_{e q}$ increased with increasing water depth (Figure 6.7D). For a variation in grain size $d$ we observed two trends. First, starting from a small grain size, 


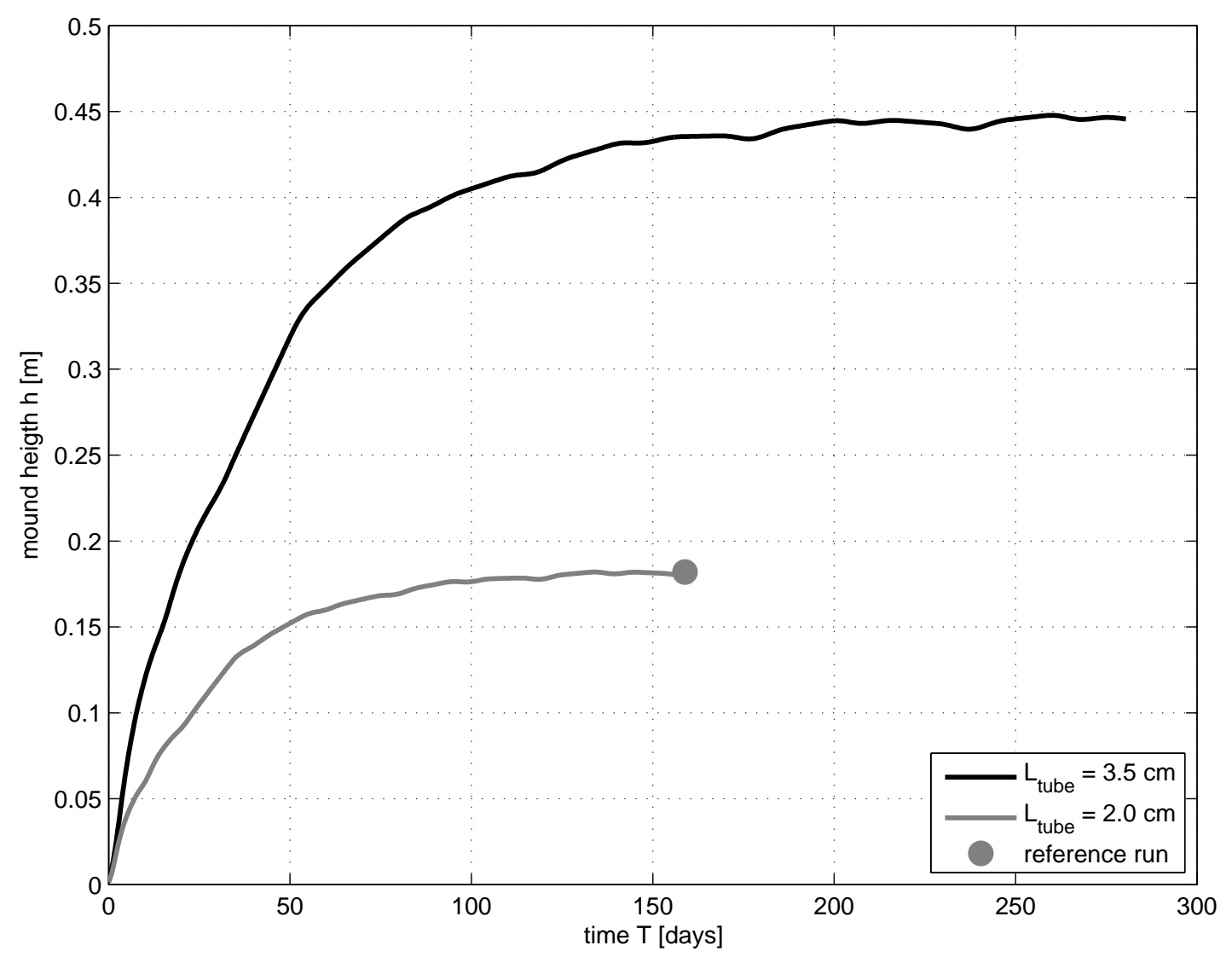

Figure 6.5: Mound formation in time for a tube density $D_{\text {tube }}=500$ ind. $\mathrm{m}^{-2}$ and a tube lengths of $L_{\text {tube }}=3.5 \mathrm{~cm}$ (black line) and $L_{\text {tube }}=2.0 \mathrm{~cm}$ (gray line). The small irregularities in mound height $h$ during growth are caused by the used MORFAC. The gray circle indicates the reference run, used for comparison.

(A)

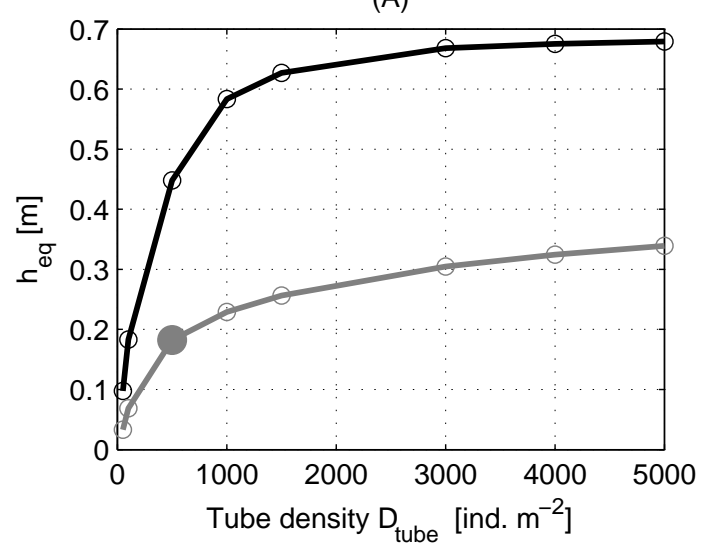

(B)

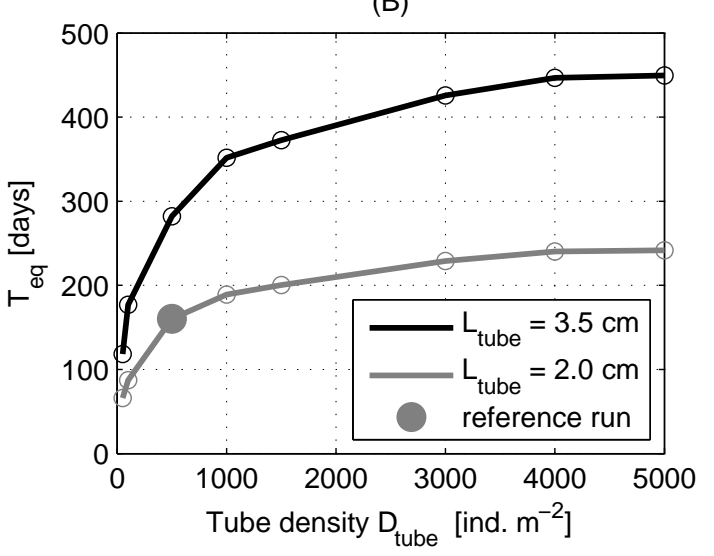

Figure 6.6: Equilibrium mound height $h_{e q}(\mathrm{~A})$ and equilibrium time $T_{e q}(\mathrm{~B})$ for increasing tube densities $D_{\text {tube }}$ and for a tube length $L_{\text {tube }}=3.5 \mathrm{~cm}$ (black line) and $L_{\text {tube }}=$ $2.0 \mathrm{~cm}$ (gray line). 
(A)

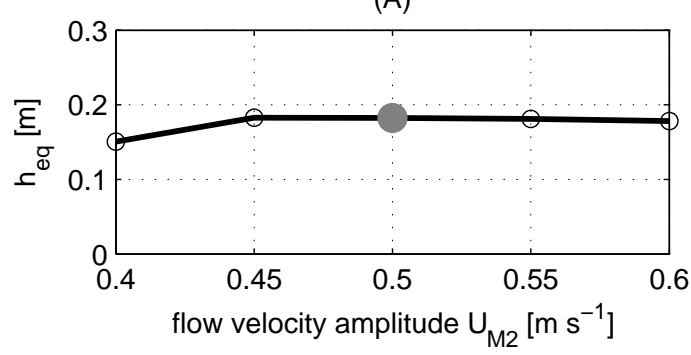

(C)

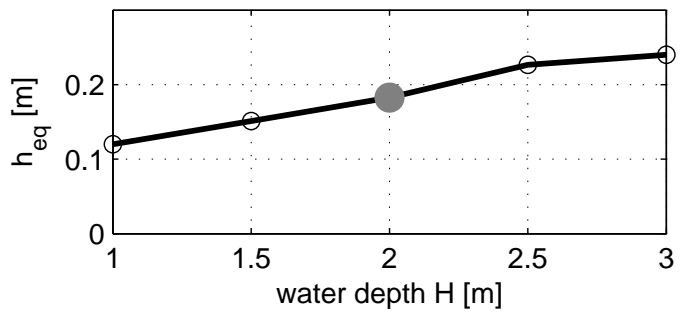

(E)

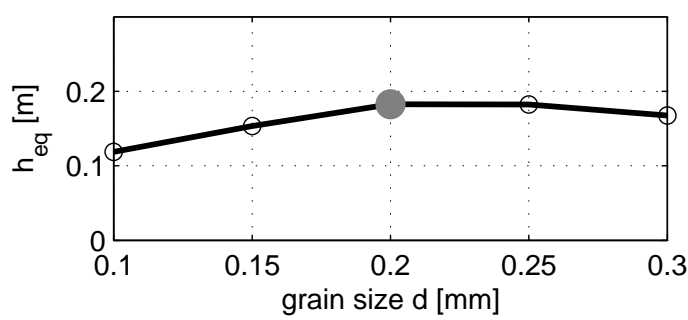

(B)

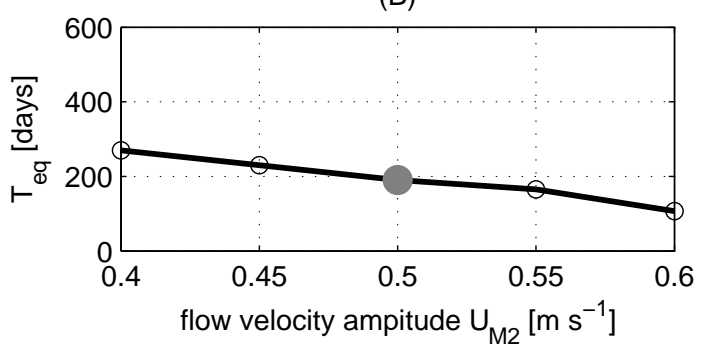

(D)

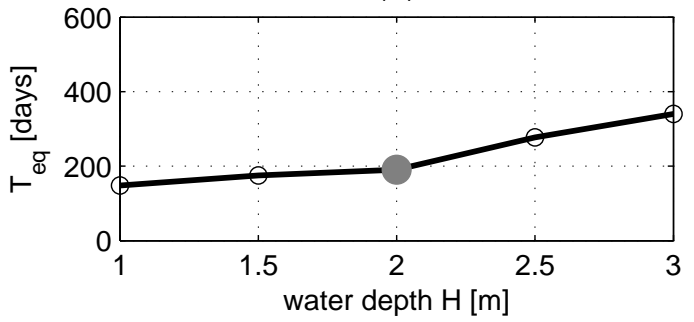

$(\mathrm{F})$

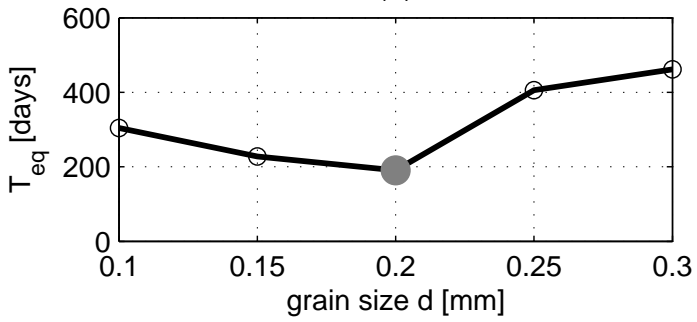

Figure 6.7: Sensitivity in equilibrium mound height $h_{e q}$ (left) and equilibrium time $T_{e q}$ (right), for a variation in flow velocity amplitude $u_{M 2}(\mathrm{AB})$, water depth $H(\mathrm{CD})$ and grain size $d(\mathrm{EF})$.

the equilibrium mound height $h_{e q}$ increased and the equilibrium time decreased for increasing grain size (i.e., from $d=0.1$ to $0.2 \mathrm{~mm})$. However, for larger grains $(d>0.2$ $\mathrm{mm}$ ) the opposite trend was observed (Figure 6.7E). For small grain sizes, the Rouse number $P$ outside the patch is within the suspended load transport regime $(P=0.47$; Table 6.2). In this regime, the small grain sizes were easily picked up from the bed, even within the patch. Consequently, the equilibrium mound height $h_{e q}$ was smaller compared to the reference run. The equilibrium time $T_{e q}$ was long in the suspended load transport regime, since the sediment was mostly transported over and along the patch. In contrast, for large grain sizes the Rouse number $P$ outside the patch was within the bedload transport regime $(P=2.72)$ and the equilibrium mound height $h_{e q}$ was comparable to the reference run (Figure 6.5: $L_{\text {tube }}=2.0 \mathrm{~cm}$ ). Nevertheless, the equilibrium time $T_{e q}$ is much longer for the larger grain size, since the total transport rate was much smaller (Figure 6.7F). The Rouse numbers $P$ for the other simulations were all within the incipient suspended load transport regime $(1.30<P<1.94$; Table $6.2)$. 


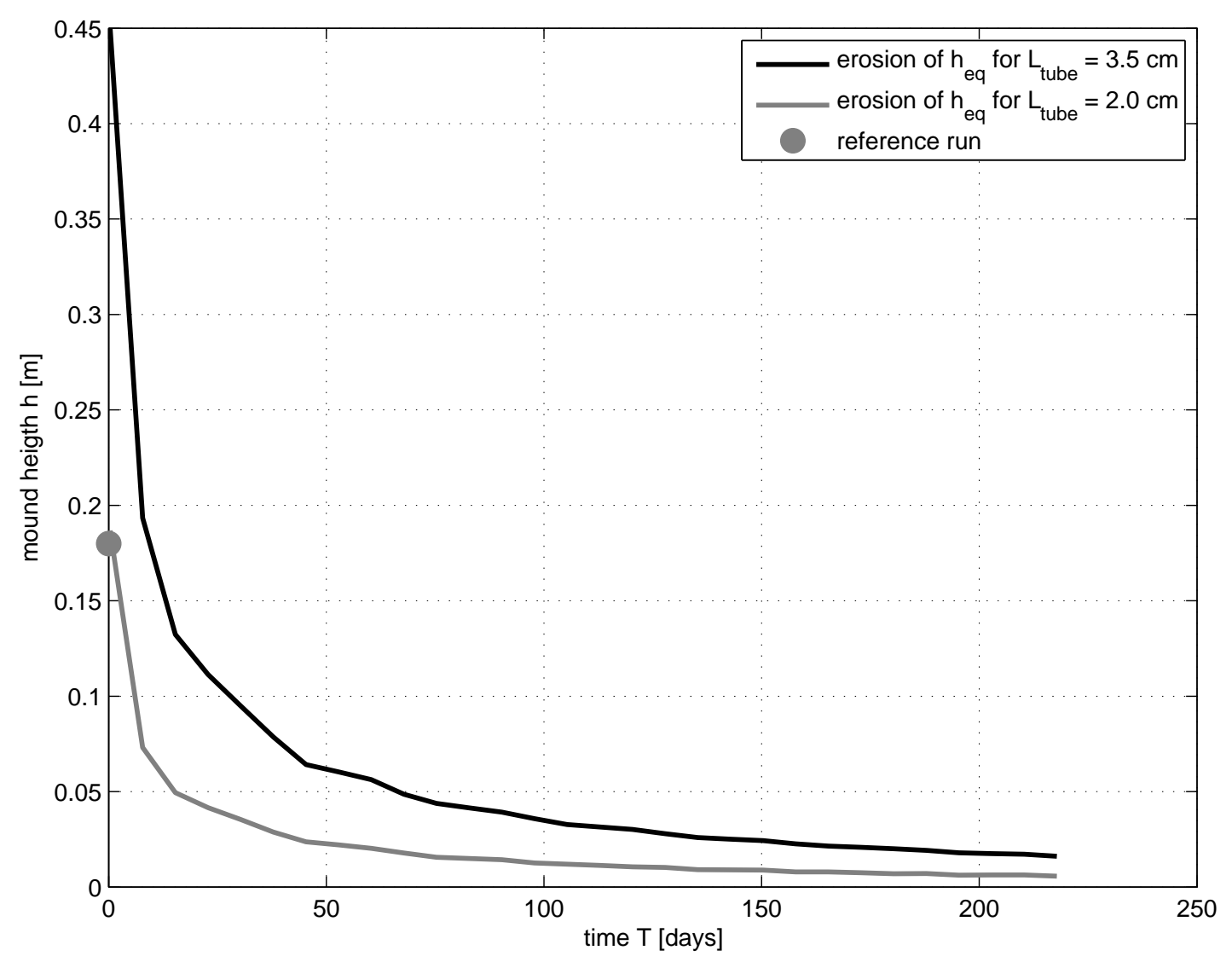

Figure 6.8: Mound degradation for two different initial topographies. The initial topographies correspond to the equilibrium mound height for a density of $D_{\text {tube }}=500$ ind. $\mathrm{m}^{-2}$ and a tube length $L_{\text {tube }}=3.5 \mathrm{~cm}$ (black line) and $L_{\text {tube }}=2.0 \mathrm{~cm}$ (black line).

\subsubsection{Modeling geomorphodynamics of patches - degradation}

Finally, the model allowed us to study the erosion of the mounds, once the tube-building worms had disappeared due to e.g. recruitment failure. As initial topography we used the equilibrium mound height reached for a tube density of 500 ind. $\mathrm{m}^{-2}$ and a tube length $L_{\text {tube }}=2.0 \mathrm{~cm}$ and $L_{\text {tube }}=3.5 \mathrm{~cm}$ (Figure 6.5). In the first weeks the mound height decreased rapidly (Figure 6.8), but later the rate slowed down and the time needed to flatten the mound (Figure 6.8) was comparable to the time needed to form the mound (Figure 6.5).

\subsection{Discussion and Conclusions}

Few studies addressed the question how organism traits of ecosystem engineering species interact with environmental forcing to affect the rates of creation and degradation of biogeomorphological structures and landscapes. The use of a physically sound model of sediment transport offered us a unique tool to quantify these processes for biogeomorphological mound-creation by the tube-building worm L. conchilega. After validating the model against flume measurements, we demonstrated that the creation and degradation rates mainly depend on biological factors (tube length and population density) 
while physical factors (flow velocity amplitude, water depth and grain size) were less important. The largest increase in equilibrium mound height was found for an increase in tube length (i.e., increase in mound height from $18 \mathrm{~cm}$ to $45 \mathrm{~cm}$ with $L_{t u b e}$ increasing from $2.0 \mathrm{~cm}$ to $3.5 \mathrm{~cm}$ for a tube density $D_{\text {tube }}=500$ ind. $\mathrm{m}^{-2}$; Figure 6.5 ). Worm density was important as long as the tube densities were low (i.e., increase mound height from $10 \mathrm{~cm}$ to $58 \mathrm{~cm}$ with $D_{\text {tube }}$ increasing from 50 ind. $\mathrm{m}^{-2}$ to 1000 ind. $\mathrm{m}^{-2}$ for a tube length $L_{\text {tube }}$ of $3.5 \mathrm{~cm}$; Figure 6.6). In contrast, variation in physical forcing hardly influenced equilibrium mound height in flow dominated environments, putting the engineering outcome in principle under the control of the population of tube worms.

Our model predictions are limited in that we could only simulate flow-dominated subtidal environments. This constitutes a natural habitat for the tube-building worm L. conchilega (Rabaut et al., 2007), but the species also occurs intertidally. Our model cannot accurately simulate this as the drying and flooding may generate numerical problems in the results if the gradient in bed level is quite large as is the case for mounds. Field studies show that mound characteristics in the intertidal environment are typically comparable to mound characteristics in the subtidal environment (Degraer et al., 2008; Rabaut et al., 2009). Therefore we feel justified to compare intertidal field observations on mound height with subtidal model results, although future research should confirm this assumption. Not being able to include waves in our model, might affect our estimates of the degradation time. Depending on the location, waves can form the major hydrodynamic force for destabilizing sediments in intertidal and shallow subtidal environments (Van der Molen, 2002). Present results on degradation rates may hence not be applicable to wave dominated environments.

As described in the introduction (Section 6.1), results from flume studies have been contradictory to the field observations: whereas in flume studies the net sediment flux switched from erosion to deposition above a roughness density of $5 \%$ (Friedrichs et al., 2009 ), field observations showed mound presence for roughness densities smaller than $5 \%$ (Rabaut et al., 2009). Based on our model results, which allowed us to explore a wide range of physical settings, we can clarify these apparent contradictory results. First of all, in the field the flow direction reverses after half a tidal period. In the flume experiment by Friedrichs et al. (2000) erosion throughout the whole tube array was only observed until a roughness density of $2 \%$. For larger roughness densities, erosion was only observed near the leading edge of the patch. Inside and at the back of the patch, the bed level was unaffected. Since the location of the leading edge changes during the tidal period, the erosion at the leading edge during the first half of the tidal period might be compensated by the accretion of sediment during the second half of the tidal period. Secondly, in the flume studies the bed roughness outside the patch is much smaller compared to field conditions. Therefore, flow velocities inside the patch are much larger in the flume studies and could therefore induce erosion, which is not observed in the field. Thirdly, in flume experiments the distribution of tube-building worms is regular and the tube length is constant. However, in the field the distribution of tube-building worms and the tube length is much more random. Consequently, energy dissipation in the field is assumed to be much higher due to the random distribution compared to the energy dissipation due to the regular distribution in the flume. Fourthly, in the flume studies no bedload transport outside the patch was accounted for. The model results showed an increase in bed shear stress outside the patch and hence erosion of sediment. This sediment settles within the patch due to a reduction in flow velocity. Fifthly and finally, stabilizing organisms like diatoms found 
within the patch in the field are assumed to bind the sediment together and therefore increase the critical bed shear stress for erosion (Eckman et al., 1981).

The results of the model showed the ecosystem engineering capacity of the tubebuilding worm $L$. conchilega. For small densities the flow velocities within the patch is relatively strongly reduced and hence sediment accretion is enhanced. As recruitment within a patch is much larger than outside a patch (Strasser and Pieloth, 2001; Van Hoey, 2006), these relatively strong effects caused by small densities of tube-building worms are likely to have a positive effect on recruitment. This may start a positive feedback loop, resulting in an increase in density and consequently an increase in mound height. However, the model results also indicate that there is a limit to this positive feedback. For a density of tube-building worms exceeding around 5000 ind. $\mathrm{m}^{-2}$ the accretion of sediment stopped. Hence our model suggests that reefs will evolve to an equilibrium that is physically determined by the prevailing hydrodynamic conditions. Feedback responses are however not yet explicitly included in the model, and need be pursued in future studies.

In nature, the patchy habitat consisting of mounds of tube-building worm L. conchilega (Figure 6.1) evolves quite dynamically, as it is very dependent on recruitment for reef renewal. L. conchilega being a short-lived species (Van Hoey, 2006), reefs can only persist over several years through renewal of the population (Godet et al., 2011). The prolonged existence of the mound as a sort of 'legacy' of the reef is important for pelagic larvae to settle (Rabaut et al., 2009). Our model results show that the mound 'legacy' can persist quite long even after a period in which worms are absent on the mounds (i.e., > 100 days; Figure 6.8). Thus, protection of areas with mounds that are temporarily not inhabited by living worms against disturbing agents such as e.g. bottom trawling is of utmost importance, because the legacy of these ecosystem engineered structures can be long enough to facilitate future establishment (Figure 6.8). In general, the dynamics including legacy of engineered structures and its role in population dynamics deserves more emphasis in ecology, and physical modeling may be a way to move this topic forward. 


\title{
Chapter 7
}

\section{Modeling bio-physical influences on seasonal variation in sand wave dynamics}

This chapter has been published as:

B.W. Borsje, M.C. Buijsman, G. Besio, M.B. De Vries, S.J.M.H. Hulscher, P.M.J. Herman, H. Ridderinkhof, 2009. On the modeling of bio-physical influences on seasonal variation in sand wave dynamics. Journal of Coastal Research 56, 698-702.

\begin{abstract}
Seasonal variation is observed in sand wave migration and sand wave length for a tidal inlet between the North Sea and the Dutch Wadden Sea (Marsdiep tidal inlet). Modeling experiments demonstrate that this seasonal variation is induced both by physical and biological processes. By including seasonal variations in (1) tides, (2) fall velocity of sediment and (3) a reduction of the near bottom flow by tube-building worms, in an idealized sand wave model, we find a quantitative agreement between the model outcomes and field measurements.
\end{abstract}




\subsection{Introduction}

The bottom of the North Sea shows a wide variety of bedforms, among which sand waves are the most mobile. These sand waves originate from the interaction between tidal flow and the sandy seabed. Residual vertical circulation cells transport sediment at the bed towards the crests (Hulscher, 1996). Sand waves have wavelengths between 100-1000 m, heights of several meters and the orientation of the crests is almost perpendicular to the direction of the main current. Field observations give an estimate of the migration of sand waves in the Dutch part of the continental shelf of $0 \mathrm{~m}_{\text {year }}{ }^{-1}$ for offshore sites up to $20 \mathrm{~m}_{\text {year }}{ }^{-1}$ for coastal sites (Van Dijk and Kleinhans, 2005). Understanding the dynamic character of the seabed is of high economic value, for example for selecting suitable locations for sandpits and windfarms (Roos and Hulscher, 2003), as well as to determine a safe burrowing depth for pipelines and telecommunication cables (Morelissen et al., 2003) and a safe navigation depth for vessels (Németh et al., 2003).

Studying the dynamics of the bottom of the seabed is not only of interest from an engineering point of view, but also from an ecological perspective. Given the high biodiversity in the subtidal area (e.g. Heip et al., 1992), insight is needed in the relation between geomorphodynamic processes and biota for the conservation and management of the biodiversity in the coastal zone. Moreover, these benthic organisms are known to influence their habitat, resulting in biogeomorphological interactions. Recently, Borsje et al. (2008b) showed that biota is able to influence the length of sand waves significantly on the Belgian Continental Shelf.

Recent studies already showed that the migration of sand waves is caused by a tidally induced residual flow (Németh et al., 2007) and higher tidal constituents (Besio et al., 2004). At the site studied in this chapter, the Marsdiep inlet in the Netherlands, the migration rate of the sand waves is up to $90 \mathrm{~m} \mathrm{year}^{-1}$ (Buijsman and Ridderinkhof, 2008a). This high migration rate is caused by the relatively high flow velocities in the tidal inlet, compared to the more moderate flow velocities in the offshore area.

The migration rate and wavelength of sand waves in the Marsdiep tidal inlet show a seasonal variation, with the highest migration rate and wavelength in winter and early spring. These relatively slowly varying seasonal variations could not be explained by the abrupt occurrence of storms or estuarine circulation (Buijsman and Ridderinkhof, 2008b).

Physical processes responsible for the seasonal variation in sand wave length and sand wave migration rate could be the variation in tides or fall velocity of sediment particles (Buijsman and Ridderinkhof, 2008b). Tidal currents are stronger in winter than in summer. Moreover, water temperature shows a minimum in winter. While the kinematic viscosity is related to water temperature, the lowest settling velocities and corresponding highest suspended sediment concentrations are expected to occur in winter. Given the strong tidal currents and high suspended sediment concentrations in winter, highest migration rates are expected in this period of the year (Buijsman and Ridderinkhof, 2008b).

The aim of this chapter is (1) to model the sand wave length and migration rate in the Marsdiep inlet and (2) to explore to what extent the seasonal variability in sand wave length and migration rate can be caused by biological and physical processes, by varying the input parameters of an idealized sand wave model.

The structure of this chapter is as follows. Section 7.2 introduces the study area. 
The data obtained from an ADCP that is mounted under a ferry, which navigates between the south and north border of the study area and the model set-up is discussed in Section 7.3. Section 7.4 presents the results of the study. After discussing the results (Section 7.5) we end by drawing some conclusions in Section 7.6.

\section{$7.2 \quad$ Study area}

The study area encompasses the inlet of the Marsdiep tidal basin $\left(52.985^{\circ} \mathrm{N}\right.$ and $4.785^{\circ} \mathrm{W}$ ), located in the western Dutch Wadden Sea (Figure 7.1). The tidal basin consists of deep tidal channels flanked by shallow sand and mud flats. The inlet is bordered by the island of Texel to the north and the town of Den Helder to the south and is about $4 \mathrm{~km}$ wide and maximally $27 \mathrm{~m}$ deep at the location where the ferry crosses. The seafloor in the inlet is covered with sand with grain sizes of $0.3-0.6 \mathrm{~mm}$ (Buijsman and Ridderinkhof, 2008b). The inlet is considered well-mixed and tides constitute up to $81 \%$ of the total variance of the water levels and $98 \%$ of the currents (Buijsman and Ridderinkhof, 2007). The semidiurnal tidal constituent $\mathrm{M}_{2}$ is the most dominant in the vertical and horizontal tides. The amplitude of water level variation is between 1 and $2 \mathrm{~m}$. Near-surface streamwise current amplitude is between 1 and $2 \mathrm{~m} \mathrm{~s}^{-1}$ for neap and spring tides, respectively. Currents are flood dominated in the southern half and ebb dominated in the northern half of the inlet. The bottom of the Marsdiep is inhabited by the tube-building worm Lanice conchilega (Holtmann et al., 1996). Lanice conchilega protrudes several centimeters from the sediment in the water column, and thereby influences the near-bottom flow. For dense tube assemblages the near-bottom flow reduces (Friedrichs et al., 2000), and consequently lower ripples are present on top of the sand waves (Featherstone and Risk, 1977). The ripples are the main origin of bottom roughness (Soulsby, 1983). The abundance of Lanice conchilega in the Marsdiep is locally extremely large (over 3000 ind. $\mathrm{m}^{-2}$ ) (Holtmann et al., 1996).

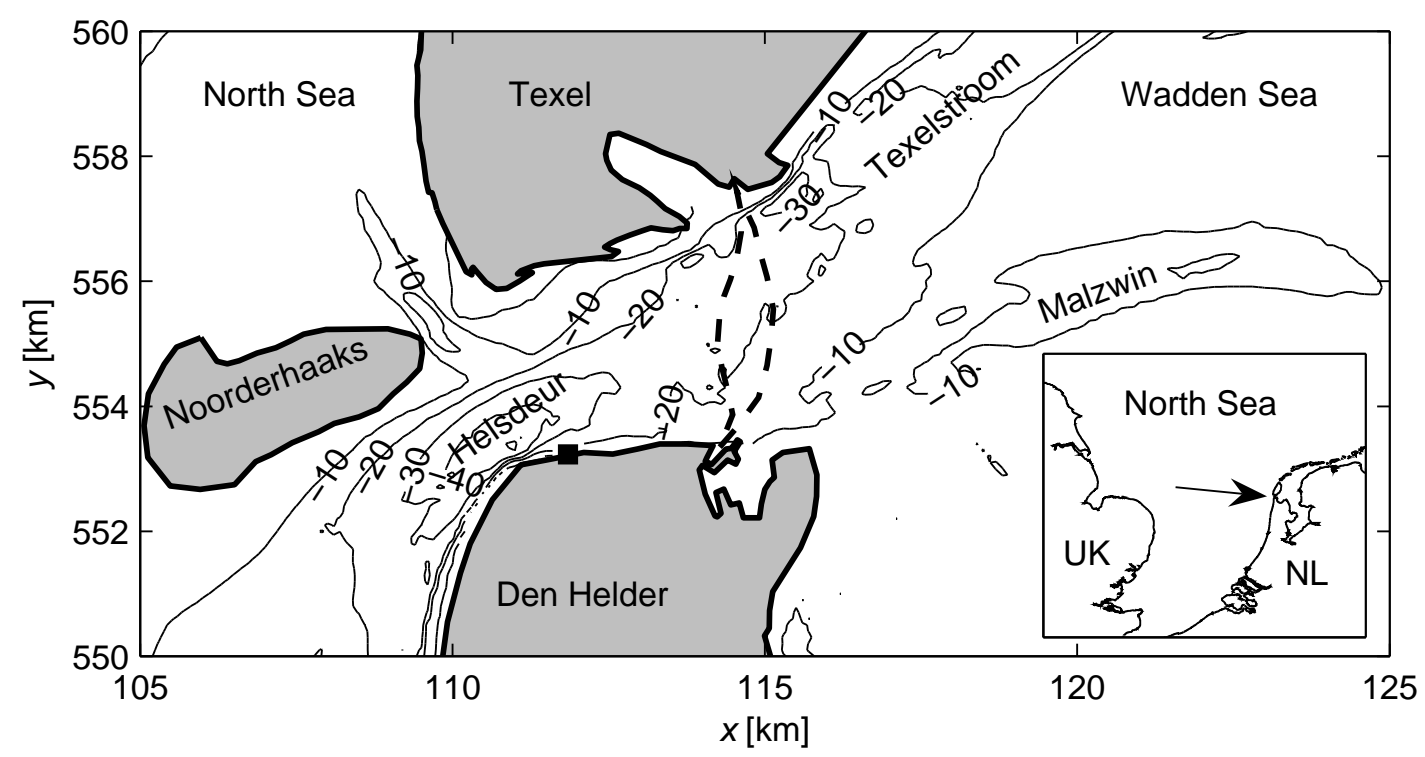

Figure 7.1: The Marsdiep tital inlet in the Netherlands. 

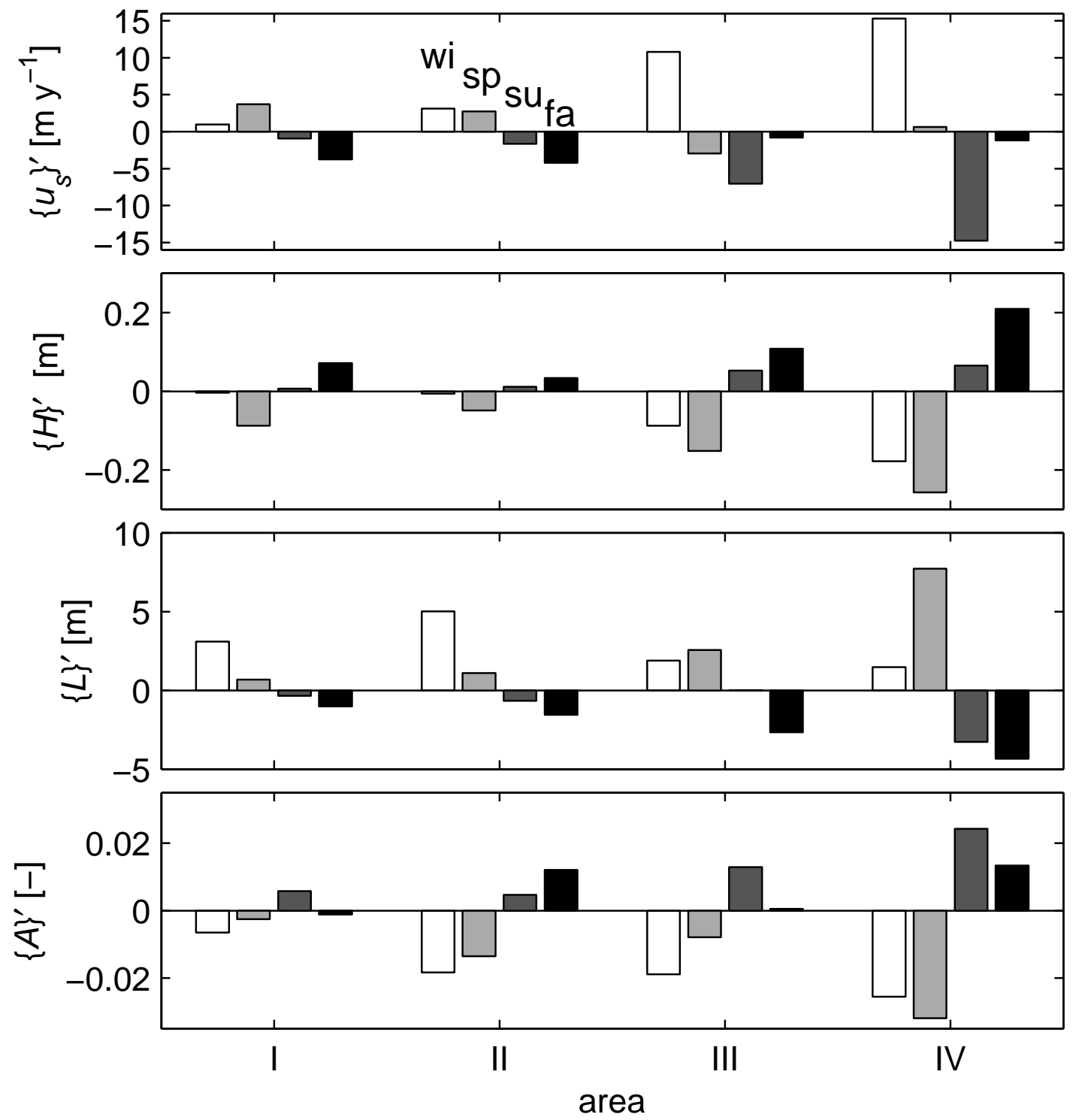

Figure 7.2: Seasonal variability around the annual mean of the migration rate $u_{s}$, heigth $H$, wavelength $L$ and asymmetry $A$ of the sand waves in the four areas. Winter, spring, summer, fall are indicated with wi, sp, su, fa (Buijsman and Ridderinkhof, 2008a).

\subsection{Data and model set-up}

For the investigation of the seasonal variation in sand wave length and migration rate, we use ADCP velocity data from 1999 to the end of 2002. The methodology to analyze the current data is presented in Buijsman and Ridderinkhof (2007). The ADCP was mounted under the ferry Schulpengat at $4.3 \mathrm{~m}$ below the water surface and recorded eastward velocities $u$, northward velocities $v$, and upward velocities $w$ in bins of $0.5 \mathrm{~m}$. The ferry crosses the inlet every half hour up to 32 times per day. Similar to Buijsman and Ridderinkhof (2008b), time gaps in the time series were filled with harmonic fits.

In addition to velocities, the ADCP also measured water depth. For the period 1998-2005 water depths collected during 30-d periods were corrected for offsets and 
assembled in bathymetric maps (digital elevation models; DEMs) with a grid size of $15 \times 15 \mathrm{~m}^{2}$. From these DEMs sand wave height $H$ and wavelength $L$ were extracted. Moreover, the sand-wave migration rate $\left(U_{w}, V_{w}\right)$ was obtained by spatially correlating patterns on DEMs that were about three months apart. In this chapter we use $u_{s}$, which is the migration rate along the main axes of $\left(U_{w}, V_{w}\right)$. A striking result is the seasonal variability in $u_{s}, H$ and $L$. We computed the mean seasonal variability for $u_{s}, H$ and $L$ around the annual mean (i.e. $\left\{u_{s}\right\}^{\prime},\{H\}^{\prime}$ and $\{L\}^{\prime}$, where \{\} indicates area averaging). The results are presented in Figure 7.2. It shows that the sand waves migrate fastest (slowest) in winter (summer), have the largest (smallest) wave heights in spring (fall), and have the largest (smallest) wave lengths in spring (fall).

To model the bio-physical influences on sand wave migration rate and sand wave length, an idealized model is adopted, which is based on a stability analysis and extensively discussed in Borsje et al. (2008b). A parameterization is added to the model to include the influence of Lanice conchilega on the deceleration of the near bed flow. For a detailed description of the parameterization of Lanice conchilega, see Borsje et al. (2009b; Chapter 5).

In order to show the physical and biological contribution to the seasonal variation in migration rate and length of the sand waves, five cases are considered. The first case is the default case, in which the proces parameters are kept constant throughout the year and only different combinations of the tidal forcing are investigated. Case 2 adds seasonal variation in water temperature to the default case. Case 3 adds seasonal variation in tides. Case 4 adds seasonal variation in biological activity and Case 5 combines all seasonal variations in cases 2-4. Evaluation of the model results is based on the seasonally averaged sand wave length and migration rate in the Marsdiep inlet (Figure 7.2).

The water temperature shows a seasonal variation, as shown in Figure 7.3. The fall velocity of the sediment is influenced by a change in water temperature, showing relative high fall velocities for warm water $\left(0.05 \mathrm{~m} \mathrm{~s}^{-1}\right)$ and relative low fall velocities for cold water $\left(0.04 \mathrm{~m} \mathrm{~s}^{-1}\right)$. Moreover, the Reynolds particle number is related to the kinematic viscosity, which in turn is related to water temperature. The lower kinematic viscosity of the water in summer will induce lower bedload transport rates for equal bed shear stresses, compared to the winter period. The seasonal variation in input parameters is expressed relative to the yearly mean value (Figure 7.4A). Seasonal variation in the

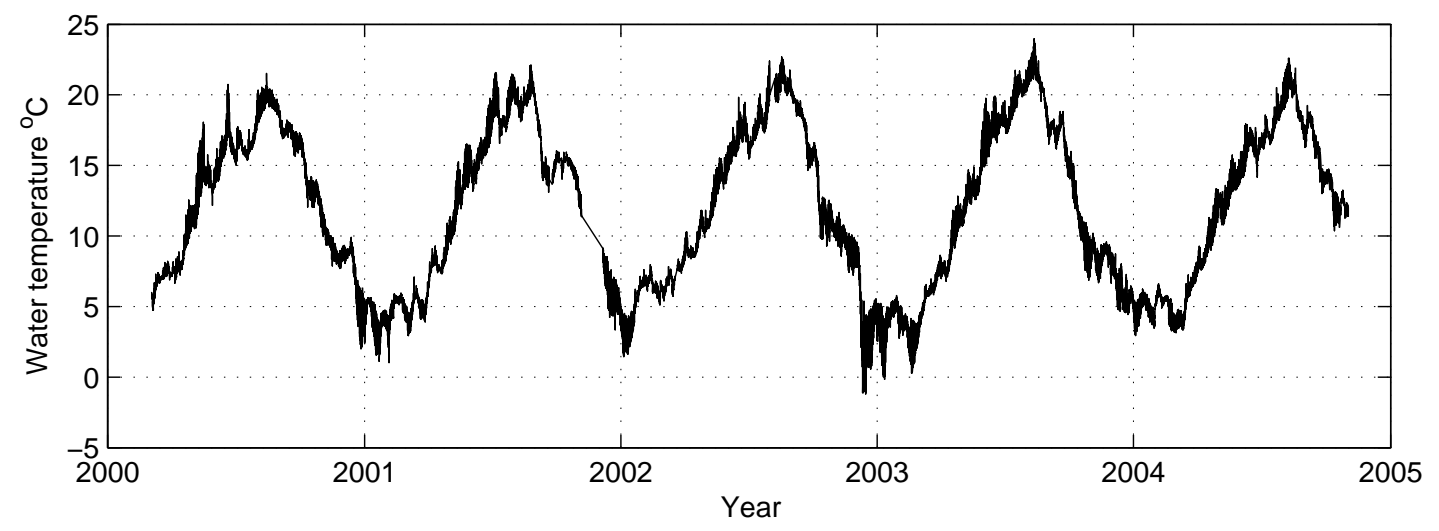

Figure 7.3: Variation in water temperature measured in the Marsdiep tidal inlet. 
Table 7.1: Process parameters.

\begin{tabular}{ll}
\hline Parameter & Value [unit] \\
\hline Grain size & $0.4 \mathrm{~mm}$ \\
Water depth & $24 \mathrm{~m}$ \\
Flow velocity $\left(\mathrm{M}_{2}\right)$ & $1.1 \mathrm{~m} \mathrm{~s}-1$ \\
Flow velocity $\left(\mathrm{M}_{4}\right)$ & $0.11 \mathrm{~m} \mathrm{~s}-1$ \\
Residual flow $\left(\mathrm{Z}_{0}\right)$ & $-0.09 \mathrm{~m} \mathrm{~s}-1$ \\
Relative phase difference between $\mathrm{M}_{2}$ and $\mathrm{M}_{4}$ & $84^{\circ}$ \\
\hline
\end{tabular}

tide is based on the measured tidal velocities (Buijsman and Ridderinkhof, 2008a). For the Marsdiep inlet, the tidal velocities are highest in winter and spring and lowest in summer and fall (Figure 7.4B). Data on temporal variation of Lanice conchilega are not available for the Marsdiep tidal inlet. However, Lanice conchilega is sensitive to low temperatures and therefore shows low densities in the area of the Wadden Sea after cold winters (Beukema, 1979). In this study, we adopt the temporal variation in biomass Lanice conchilega from a modeling study on two different bio-engineering species in the Western Wadden Sea (Borsje et al., 2008a). These two species (Macoma balthica and Hydrobia ulvae) have their smallest biomass in late winter and spring, and their largest biomass in fall (Figure 7.4C). The default model settings are shown in Table 7.1.

\subsection{Results}

For Case 1, the modeled wavelength is around $250 \mathrm{~m}$ (Figure $7.5 \mathrm{~A}$ ). This value is comparable to the measured wavelength of around $200 \mathrm{~m}$ in the Marsdiep inlet. The wavelength of the sand waves is hardly dependent on the combination of tidal constituents, showing that the $\mathrm{M}_{2}$-tidal component has the largest contribution to the wavelength of the sand waves (Table 7.1). However, the migration rate of the sand waves is greatly dependent on the different combinations of the tidal forcing. For the given settings of the tidal forcing, the $\mathrm{Z}_{0}$-component has a positive impact on the migration rate and the $\mathrm{M}_{4}$-component has a negative impact on the migration rate.

Given a measured migration rate of around $60 \mathrm{~m}_{\text {year }}{ }^{-1}$ we can conclude that the model is able to reproduce both the wavelength and migration rate of the sand waves in the Marsdiep inlet fairly well.

Concerning the seasonal variability in the wavelength and the migration rate of the sand waves, there is a striking difference (Figure 7.6). The variation in water temperature and biomass of Lanice conchilega are the main potential contributions to the seasonal variability in wavelength, while the seasonal variation in tidal velocity is mainly causing the seasonal variability in migration rate. Moreover, physical and biological processes show a non-linear interaction, when both processes are combined in Case 5.

The seasonal variability in sand wave migration rate is related to the variation in tidal velocity (Figure 7.4B), in such a way that higher tidal velocities cause a higher migration rate for sand waves. However, the relation between causal factors and variability in the wavelength of sand waves is much more complicated. In the winter period, a relative low biomass of Lanice conchilega causes higher suspended sediment concentrations compared to the default case. Furthermore, the low water temperature induces 

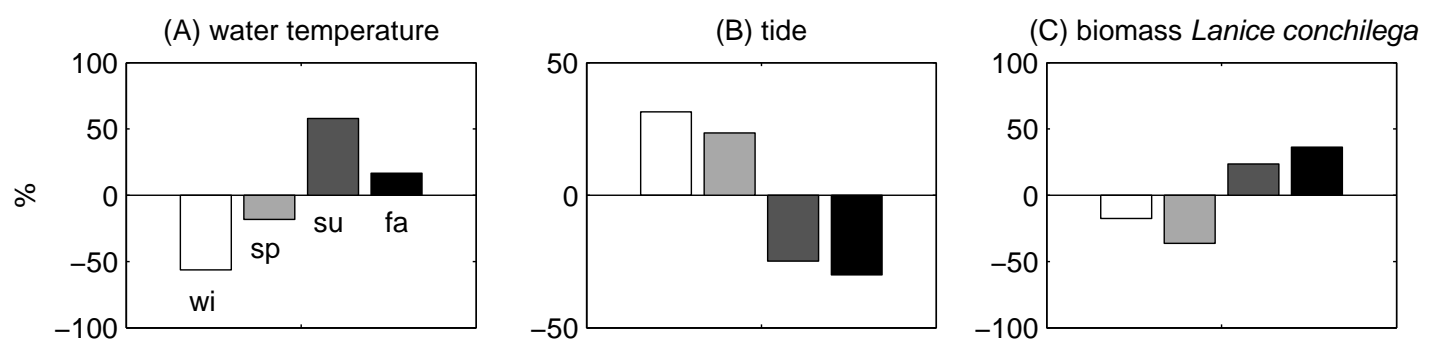

Figure 7.4: Seasonal variability around the annual mean of water temperature (A), tidal velocity (B) and biomass Lanice conchilega (C).
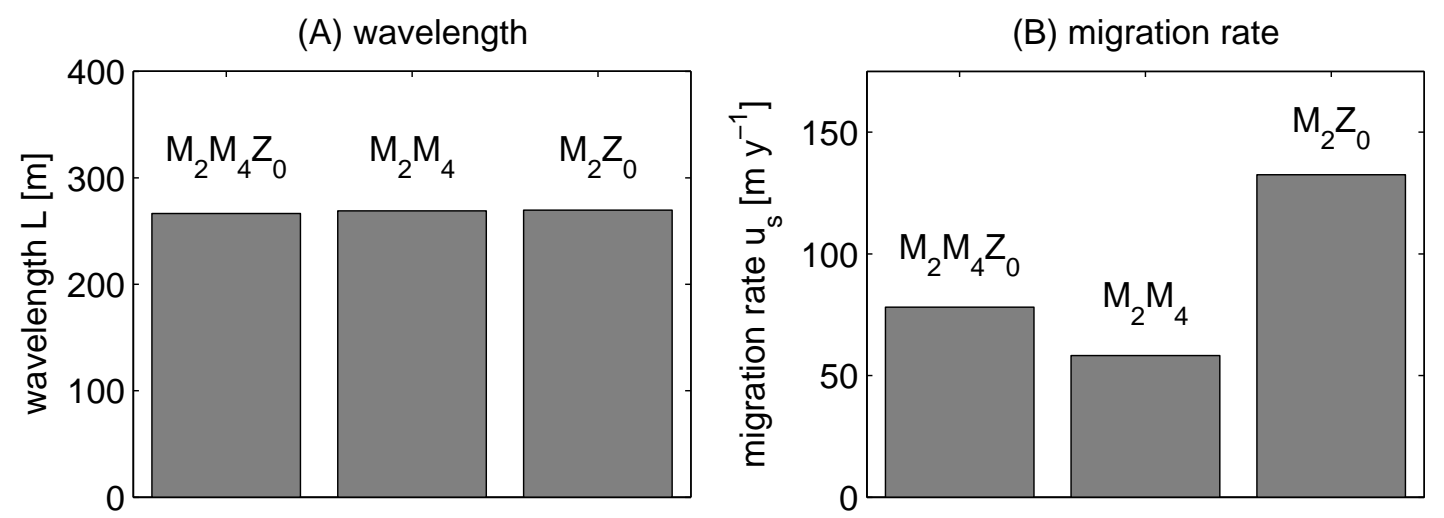

Figure 7.5: Modeled wavelength (A) and migration rate (B) for different combinations of the tidal forcing (Case 1).
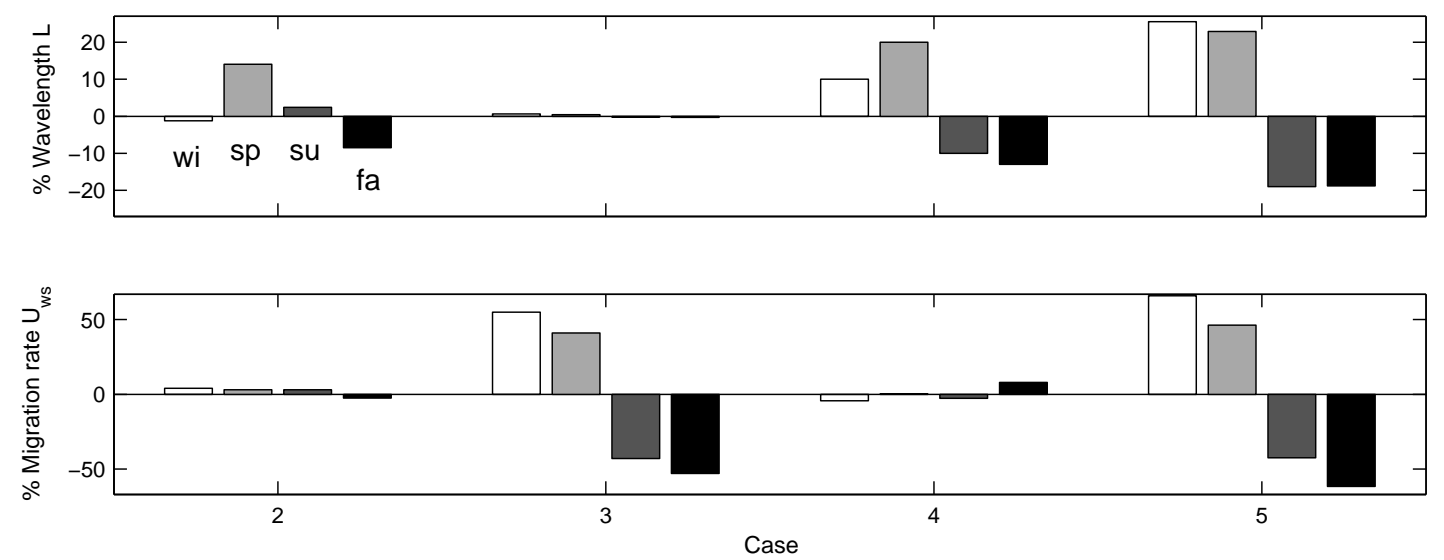

Figure 7.6: Seasonal variability expressed in percentage of the mean wavelength and migration rate (Case 1) caused by a seasonal variation in water temperature (Case 2), tidal velocity (Case 3), biomass Lanice conchilega (Case 4) and a combination of these bio-physical processes (Case 5). 
a relatively low fall velocity, resulting in sediment which is carried longer in suspension compared to the default case. Suspended sediment has a damping effect on the formation of sand waves (Borsje et al., 20012b; Chapter 3), therefore the sand wave length in winter (when suspended sediment concentrations are higher) is higher, compared to the default case. In spring, the biomass of Lanice conchilega is even lower. However, the water temperature is higher compared to the winter period. Therefore, the amount of sediment in suspension is comparable for both periods and consequently also the wavelength of the sand waves is comparable in both periods of the year. In summer, the biomass of Lanice conchilega is relatively high, resulting in relatively low suspended sediment concentrations. Combined with a high water temperature and corresponding high fall velocity, the sand wave length is much smaller, compared to the default case. Finally, in fall, both the water temperature and the biomass of Lanice conchilega are relatively high, resulting in smaller wavelength of the sand waves. In general, the physical and biological processes show a dynamic interaction concerning the wavelength of the sand waves. Biological processes determine the amount of bedload and suspended sediment transport. Water temperature determines how long the sediment is carried in suspension. Therefore whether the wavelength of the sand waves is either larger or smaller compared to the default case is determined by the biological processes. However, the exact change in wavelength is determined both by the biological and physical processes. Concerning the migration rate of the sand waves, the physical process (tidal velocity) is dominant compared to the biological process and, as a result, no dynamic interaction is found.

Seasonal variability in sand wave lengths is as much as $15 \%$ of the annual mean sand wave length, while variability in migration rates are about $60 \%$ of the annual mean migration rate, as measured in the field by Buijsman and Ridderinkhof (2008a). Based on a comparison between the modeling results and the field measurements (Figure 7.6), we can conclude that both physical and biological processes are capable of explaining the seasonal variability in wavelength and migration rate of sand waves in the Marsdiep inlet. The modeled variation is comparable in magnitude to the measured variation in the field.

\subsection{Discussion}

This chapter explores the causes for seasonal variation in sand wave length and migration rate. In this study, we took a representative case, for which the parameter setting is comparable to the Marsdiep inlet. However, without knowing the exact seasonal and spatial variation in biomass of Lanice conchilega in the study area, we are not able to model the site specific variation in sand wave length and migration rate. Moreover, the grain size used in this study is uniform, while in the field a sorting process is observed with almost twice as large medium grain sizes in the crests of the sand waves compared to the troughs at some locations (Buijsman and Ridderinkhof, 2008a).

As observed by Buijsman and Ridderinkhof (2008b), also the height of the sand waves shows a seasonal variation (Figure 7.2). The code used in this study, is based on a linear stability analysis, and therefore not able to give a prediction for the sand wave height. By including the physical and biological processes in a non-linear code (e.g. Németh et al., 2007), we are able to model the seasonal variation in sand wave

height as well. Moreover, a non-linear code will give us the possibility to include sorting effects and the corresponding implications for seasonal variation in sand wave length 
and migration rate.

Despite the shortcomings mentioned above, the present study demonstrates that an idealized model may be an useful way of assessing the impact of biological and physical processes on seasonal variation in sand wave dynamics.

\subsection{Conclusions}

This chapter demonstrates that biological and physical processes are capable of causing the seasonal variation in migration rate and wavelength of sand waves in the Marsdiep inlet (The Netherlands).

As model input the measured variation in (i) flow velocity and (ii) water temperature is used and moreover, an assumption on (iii) the biomass variation of the tube-building worm Lanice conchilega is included in the biogeomorphological model. Model results reveal that the three processes contribute differently to the seasonal variation in sand wave characteristics. Firstly, both the variation in water temperature and the biological processes may cause the variation in wavelength of the sand waves. Variation in tidal velocity is the main determinant for the variation in migration rate of the sand waves in the Marsdiep inlet. Finally, biological processes and physical processes show a nonlinear interaction, meaning that the outcome of the interaction is not simply the sum of the two different components. As a result, the biological process dominates the seasonal variation in sand wave length while the variation in tidal velocity dominates the seasonal variation in sand wave migration. 


\title{
Chapter 8
}

\section{Self-organization in the underwater landscape: exploring bio-physical interactions in tidal sand wave fields}

This chapter has been published as:

B.W. Borsje, S.J.M.H. Hulscher, P.M.J. Herman, S. Degraer, 2012. Self-organization in the underwater landscape: exploring bio-physical interactions in tidal sand wave fields. International Conference on Coastal Engineering (ICCE), in press.

\begin{abstract}
The underwater landscape of shallow shelf seas comprises different types of bed patterns, for which tidal sand waves are the most dynamic ones. Moreover, tube-building worm patches are known to impact the migration rates, the dimensions and the occurrence of sand waves. Therefore, in this chapter we focus on the formation of sand waves and the impact of mounds created by tube-building worms on these formation processes. All previous model studies on sand wave formation are based on the yet untested hypothesis that sand waves are self-organizational properties of the interaction between the tidal current and the sandy seabed. In order to test this hypothesis, we first compared the outcome of a schematized sand wave model in which the fastest growing mode is determined for a rhythmic sand wave field after one tidal cycle with the outcome of a self-organizational sand wave model in which the dominant wavelength is determined for a sand wave field which consists of a combination of wavelengths after 20 years of morphological development. We found that the fastest growing modes were close to dominant wavelengths after self-organization. Next, both the spatial and seasonal variation in tube-building worm density was prescribed and the morphological development after 20 years was studied in a two-way coupled bio-dynamic model.
\end{abstract}




\subsection{Introduction}

The bed of shallow self seas is covered with bed patterns which often show a surprisingly high degree of order. They result from the complex interaction between tidal flow and the sandy seabed. The most dynamic bed patterns are tidal sand waves, with typical wavelengths of hundreds of meters, amplitudes in the order of meters and migration rates up to tens of meters per year. The orientation of tidal sand waves is almost perpendicular to the direction of the main tidal current (Terwindt, 1971; McCave 1971). Sand waves are observed in many tide-dominated sandy shelf seas such as the North Sea, Bisanseto Sea, Irish Sea, the shelf off Spain and Argentina and in many straits and tidal inlets around the world (Van Santen et al., 2011). It is the combination of dimensions, dynamics and occurrence that makes tidal sand waves such a relevant marine bed pattern.

The bed of sandy shelf seas is also known as a valuable ecosystem. Different communities can be found on the sandy seabed (Heip et al., 1992; Künitzer et al., 1992; Rabaut et al., 2007) showing a strong spatial and temporal variation (Van Hoey et al., 2004; Baptist et al., 2006). Most of the species live in the top centimeters of the seabed and are known as ecosystem engineering species (Jones et al., 1994), i.e. organisms that change their environment in ways not done by physical processes alone (Rhoads, 1974; Nowell et al., 1981). Macrobenthic ecosystem engineers either rework the substrate (bioturbation) for feeding, burrowing, locomotion and ventilation (Meysman et al., 2006), or provide structure by themselves that can be used by other species. The stabilizing or destabilizing effect on the bed can modify sediment fluxes by a factor 2 and more, compared to the purely physical case (Graf and Rosenberg, 1997; Widdows and Brinsley, 2002; Friedrichs and Graf, 2009).

Recently, we demonstrated the potential impact of ecosystem engineering species on the migration rate, dimensions and occurrence of tidal sand waves (Borsje et al., 2009abc; Chapter 4, 5, 7). Borsje et al. (2009b; Chapter 5) showed that animal effects can be sufficient to switch the model behavior from presence to absence of sand waves in considerable parts of the North Sea off the Holland coast. This was mainly due to the stabilizing effect of the tube-building worm Lanice conchilega. However, only the one-way coupling between the static activity and homogeneous distribution of ecosystem engineering species to the stability of the seabed was studied. The feedback from the physical processes to the distribution of ecosystem engineering species (twoway coupling) could not be included in this model. Apart from the simplifications in the coupling between ecosystem engineering species activity and the morphodynamics, also fundamental simplifications are present in the current sand wave models.

Sand wave formation by tidal motion has been studied using idealized theoretical models. The first model on sand wave formation was formulated by Hulscher (1996). She showed that the interaction of the oscillatory tidal current with a bottom perturbation gives rise to a tide-averaged residual circulation directed from the trough towards the crest of a tidal sand wave. This residual circulation induces a net sediment flux towards the crest of the wave, which leads to growth of the wave if the sediment transport overcomes the opposing effect of gravity. The model by Hulscher (1996) was extended in several studies, focusing on the hydrodynamic solution method (Gerkema, 2000; Besio et al., 2003), the inclusion of residual currents and/or overtides (Németh et al., 2002; Besio et al., 2004), turbulence formulation (Komarova and Hulscher, 2000), suspended load (Blondeaux and Vittori, 2002ab) and grain size variations (Van Oyen 
and Blondeaux, 2009). The main limitation is that all models listed above are only valid for the initial stage of formation of sand waves (small amplitude sand waves; the linear regime). When amplitude increases, non-linear effects become important but these effects cannot be quantified with a linear approach. The model validity is thus limited to small-amplitude sand waves. Therefore comparison between wavelengths found in a linear stability analysis with wavelengths found in the field is questionable, despite the reasonable qualitative agreement (Cherlet et al., 2004; Van Santen et al., 2009). Németh et al. (2007) and Sterlini et al. (2009) proposed a non-linear model in which the sand wave behavior is modeled from its initial stage until an equilibrium shape in a two dimensional vertical model (2DV). In both models, the simulations start with a small-amplitude sinusoidal bed perturbation, with a wavelength based on the fastest growing mode given by a linear stability analysis. The domain length is restricted to the wavelength of a single sand wave, since model simulations on a larger domain show a tendency for the sand wave field to evolve towards one large bedform with a wavelength equal to the domain length (Sterlini et al., 2009). In conclusion, the study of sand wave formation by idealized models is limited, because sand waves formation cannot be initiated by random perturbations as is the case in nature and the domain length determines the wavelength of the outcome. The hypothesis that self-organization occurs in sand wave formation has never been tested and the self-organizational properties by which a natural, random seabed is organized into a regular sand wave field has yet to be conclusively demonstrated.

Recently, sand wave formation is modelled in a numerical shallow water model (Borsje et al., 2012ab; Chapter 2, 3). The model used (Delft3D) is a process-based model in which the same physical processes are included as in the idealized sand wave models, but non-linear and spatially heterogeneous phenomena are allowed for. Thus, the model formulations incorporate site-specific characteristics of flow, sediment and bathymetry, spatially and temporally variable turbulence formulations, sediment transport formulations for both bedload and suspended load. The model allows us to study the self-organization of tidal sand waves and to include the heterogeneous distribution of ecosystem engineering species in space and time. Consequently, we are able to study the two-way coupling between physical processes and ecosystem engineering activity in sand wave formation.

In this study, we aim to provide a mechanistic understanding of the self-organizational behavior of sand wave fields and the impact of spatially and temporally variable densities of ecosystem engineering species on the formation of sand wave fields. We will do this by using three different model set-ups in the Delft3D model. The first model set-up (schematized sand wave model) is comparable to the model set-up of idealized sand wave models: a regular sand wave field with a constant wavelength and small amplitudes. After one year of morphological development the growth rate is determined. Next, by varying the wavelength of the sand wave field in successive runs the wavelength with the fastest growth is determined. The second model set-up (self-organizational sand wave model) consists of a sand wave field composed of random perturbations with different wavelengths. After 20 years of morphological development the dominant wave length is determined. The third model set-up (bio-dynamic sand wave model) is identical to the self-organizational sand wave model but includes the impact of spatially and temporally variable densities of ecosystem engineering species. The bed level is analyzed after 20 years of morphological development.

The outline of this chapter is as follows. First, the model set-up is given for the 
schematized sand wave model (Section 8.2.1), the self-organization sand wave model (Section 8.2.2) and the coupled bio-dynamic sand wave model (Section 8.2.3). Next, model results for the schematic sand wave model are given (Section 8.3.1) and results for the self-organizational sand wave model are presented and compared with model results for the schematic sand wave model (Section 8.3.2). Moreover, model results are presented for the bio-dynamic sand wave model (Section 8.3.3). Finally, the main findings of this chapter are discussed (Section 8.4), and the conclusions are given (Section $8.5)$.

\subsection{Model}

\subsubsection{Schematized sand wave model}

The formation of sand waves is modeled using the numerical shallow water model Delft3D-FLOW (Lesser et al., 2004). In the model, both bedload and suspended load sediment transport is included and a spatially and temporally variable turbulence closure model is adopted $(k-\epsilon)$. The model description for the Delft3D sand wave model and the intercomparison between idealized sand wave models and the Delft3D sand wave model is discussed in detail in Borsje et al. (2012a; Chapter 2).

In this study, the model is run in a $2 \mathrm{DV}$ mode, i.e. considering flow and variation in vertical and only one horizontal direction, while assuming zero flow and uniformity in the opposite horizontal direction and ignoring Coriolis effects. At the length scales of sand waves, Coriolis effects are assumed to have a negligible effect (Hulscher, 1996). The horizontal model domain is 50 kilometers, with a variable horizontal resolution. In the central part of the model domain the grid size is 10 meters, increasing to a value of $1500 \mathrm{~m}$ at the lateral boundaries. In the vertical, the model grid is composed of 20 layers, with small vertical resolution near the bed and increasing towards the water surface. At the lateral boundaries, a so-called Riemann boundary condition is imposed (Verboom and Slob, 1984), for which outgoing waves are allowed to cross the open boundary without being reflected back into the computational domain, as happens for other type of boundary conditions. The tidal period $T_{M 2}$ of the semidiurnal depth-averaged velocity amplitude $U_{M 2}$ is set at 12.5 hours. The initial bed level perturbation $z_{b}$ is prescribed by a multiplication of a sinusoidal sand wave pattern of a given wavelength $L$ and amplitude $A$ with an envelope function, ensuring a gradual transition from the flat bed towards the sand wave field in the centre of the domain (Figure 8.1A). Consequently, a coarser grid can be used near the boundaries. The Chézy roughness coefficient $C$ is set at $65 \mathrm{~m}^{1 / 2} \mathrm{~s}^{-1}$. While we focus on the formation of tidal sand waves, the initial amplitude of the sand wave $A_{0}=0.5 \mathrm{~m}$. Smaller initial amplitudes show the same quantitative behavior but require more vertical layers to reproduce the near-bed flow characteristics and are consequently more time consuming. The model is run for two tidal cycles. The first tidal cycle is used for spin-up and no bed level changes are allowed. During the second tidal cycle bed level changes are allowed. Assuming exponential growth (which is valid for small-amplitude sand waves (Besio et al., 2008)), the growth rate $\gamma_{R}$ for the bed perturbation is calculated by:

$$
\gamma_{R}=\frac{1}{T} \Re\left[\log \left(\frac{A_{1}}{A_{0}}\right)\right],
$$

where $T$ is the tidal period, $A_{1}$ is the bed amplitude of the sand wave after one tidal cycle and $A_{0}$ the initial amplitude. $A_{1}$ is determined by a Fast Fourier Transform 
(A) Initial bathymetry schematised sand wave model

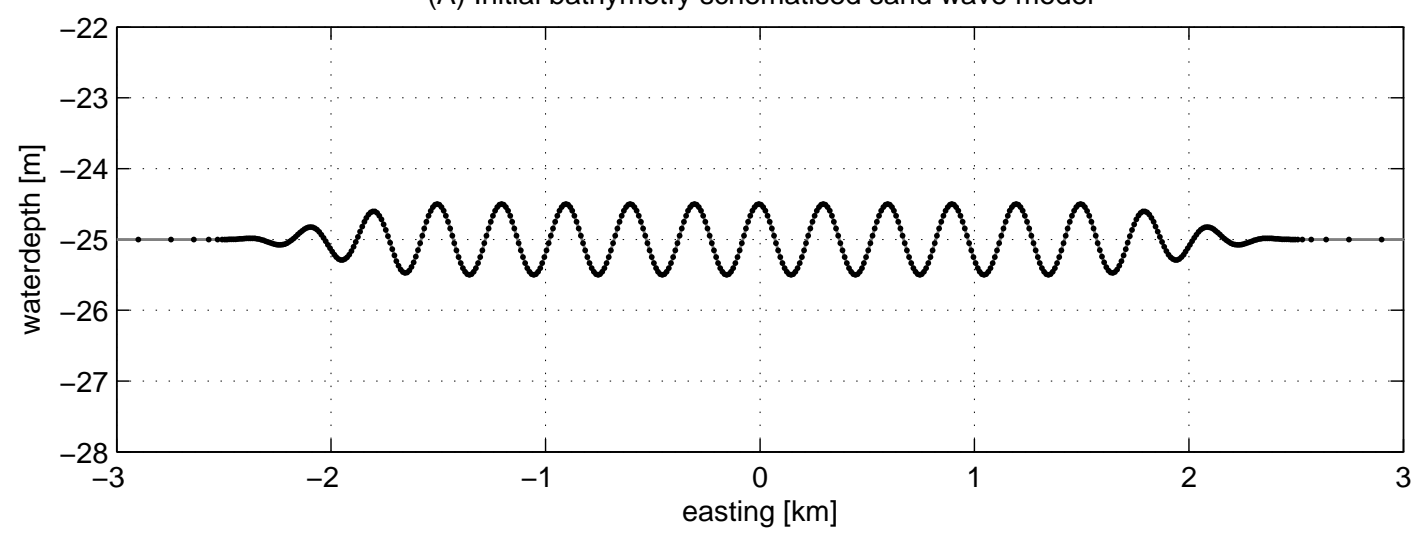

(B) Initial bathymetry self-organizational sand wave model

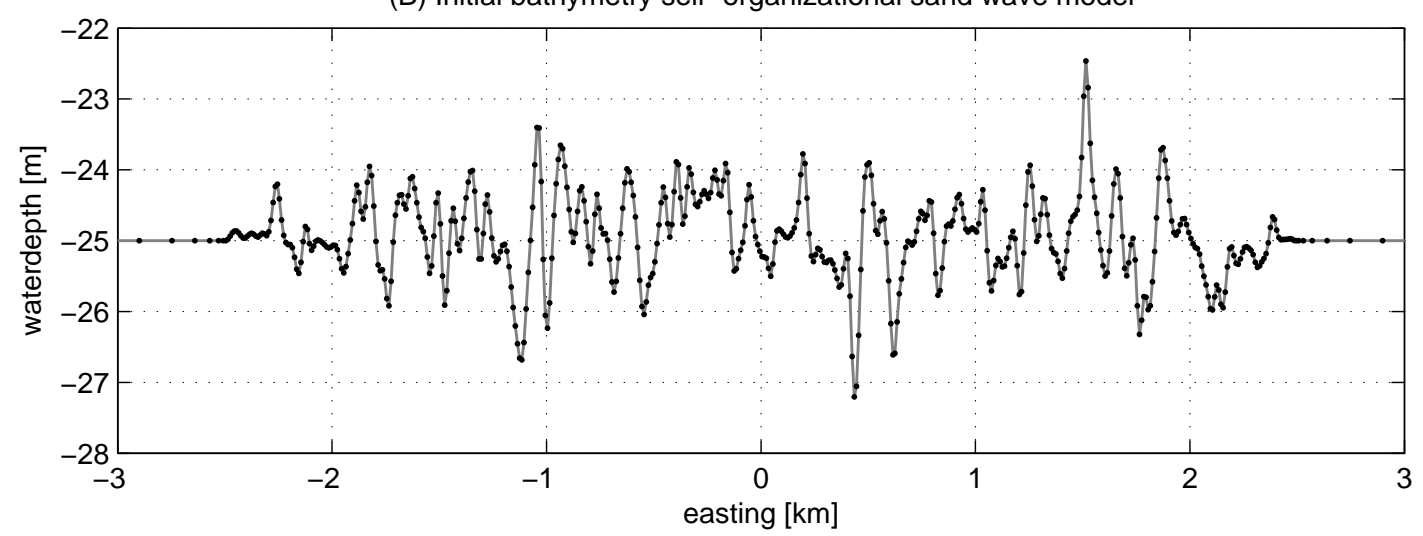

Figure 8.1: Initial bathymetry for the schematized sand wave model with a wavelength $L=300 \mathrm{~m} \mathrm{(A)} \mathrm{and} \mathrm{initial} \mathrm{bathymetry} \mathrm{of} \mathrm{the} \mathrm{self-organizational} \mathrm{sand} \mathrm{wave} \mathrm{model} \mathrm{(B).}$ The total model domain is $50 \mathrm{~km}$ and horizontal grid points are indicated with dots.

(FFT) of the central part of the sand wave domain. Positive values of $\gamma_{R}$ indicate growth of the bottom perturbation, whereas negative values indicate decay.

\subsubsection{Self-organizational sand wave model}

The model set-up of the self-organizational sand wave model is identical to the model set-up of the schematized sand wave model except for two modifications. First of all, the initial bathymetry consists of arbitrarily superimposed and sized perturbations taken from a Gaussian distribution, scaled to a mean amplitude of $0.5 \mathrm{~m}$ (Figure 8.1B). Secondly, the model is run for a time period of 20 years. To speed up the geomorphological changes, a geomorphological acceleration factor (MORFAC) of 175 is used. By using a MORFAC of 175 the deposition and erosion fluxes are multiplied with a factor 175 during each time step. Consequently, one tidal period corresponds to 12.5 hours * $175 \approx 0.25$ year of geomorphological changes. Smaller MORFAC values showed quantitatively the same results but required longer simulation times. Ten different initial bathymetries are modeled and the wavelength of the dominant tidal sand wave field after 20 years are analyzed by means of a FFT. 


\subsubsection{Bio-dynamic sand wave model}

The model set-up of the bio-dynamic sand wave model is identical to the model set-up of the self-organizational sand wave model except for one modification: the inclusion of ecosystem engineering species. In our study we focus on the widely distributed tubebuilding worm Lanice conchilega, as a model species. Lanice conchilega is an ecosystem engineering species that lives in patches and creates rigid tubes that are for the main part buried in the seabed, but protrude 1-4 cm from the sediment (Ziegelmeister, 1952). Although small, these tubes directly influence the near-bed water flow and thereby the sediment dynamics (Eckman et al., 1981). Field studies have shown that patches of Lanice conchilega raise the sea bed by sediment trapping in between the protruding tubes (Carey, 1987; Degraer et al., 2008; Rabaut et al., 2009). By extending the tubes after sedimentation, Lanice conchilega mounds can reach a height of 10 to $80 \mathrm{~cm}$ above the surrounding seabed. Borsje et al. (2012c; Chapter 6) combined flume experiments and field observations to validate a model tool in which the interaction among the hydrodynamics, sediment dynamics and the tube-building worms were quantified. This model tool explicitly accounts for the influence of cylindrical structures on drag and turbulence by an extra source term of friction force in the momentum equation and an extra source term of Total Kinetic Energy (TKE) and turbulent energy dissipation in the turbulence closure model (Dijkstra and Uittenbogaard, 2011). As parameters, only the tube-building worm density and the tube length protruding from the sediment need to be defined. The tube protruding length is set at $2 \mathrm{~cm}$ and the spatial and temporal variation in tube-building worm density is based on the variation in bed shear stress and the suspended sediment concentrations as will be discussed below.

In order to prescribe the spatial and temporal variation in tube-building worm density we make five assumptions:

1. There are three recruitment periods for the tube-building worms (spring, summer and autumn), following field observations during a sampling campaign along the Belgian coastline (Van Hoey, 2006).

2. $10 \%$ of the area is covered by tube-building worms after seeding, following field observations at the Belgian coastline by Rabaut et al. (2009).

3. Once a patch is formed, all recruitment occurs within the patch, since field observations in the German Wadden Sea show that all juvenile tubes were directly attached to the tubes of the adult worms (Heuers and Jaklin, 1999).

4. Recruitment factors are higher at locations where the suspended sediment concentrations are higher since tube-building worms are filter-feeders (Buhr, 1976).

5. All tube-building worm patches disappear during winter, since tube-building worms are sensitive to low water temperatures (Strasser and Pieloth, 2001).

By using a MORFAC of 175 , every tidal period corresponds to a season ( 0.25 year) of morphological changes. Therefore, the update in tube-building worm density is done after every tidal cycle. First, the model is run during winter and the tube-building worm density for the winter $D_{\text {tube,winter }}=0$ ind. $\mathrm{m}^{-2}$. After winter, the tide-averaged bed shear stress is determined and tube-building worms are randomly seeded at locations where the tide-averaged bed shear stress is smaller than the mean tide-averaged bed shear stress in the model domain. Consequently, tube-building worm patches are only 
seeded where the tube-building worm seedlings will not be eroded by the water motion. The tube-building worm density during spring $D_{\text {tube,spring }}$ is calculated as follows:

$$
D_{\text {tube,spring }}=D_{\text {tube, } \text {,initial }}(\text { chance }=10 \% \text { if }\langle\tau\rangle \leq \text { mean }\langle\tau\rangle),
$$

where $D_{\text {tube,initial }}$ is the initial density of the tube-building worms, which is set at 50 ind. $\mathrm{m}^{-2}$. Tube-building worms are only seeded at $10 \%$ of the area for which the tide-averaged bed shear stress $\langle\tau\rangle$ is smaller than the mean tide-averaged bed shear stress for the model domain.

After spring, the tube-building worm densities are adapted based on the concentration of suspended sediment, which is assumed to correlate with the food availability for the filter-feeding tube-building worms and hence the recruitment. The tube-building worm density during summer $D_{\text {tube,summer }}$ is calculated as follows:

$$
D_{\text {tube,summer }}=D_{\text {tube,spring }}(r(\langle c\rangle / \max \langle c\rangle)),
$$

where $r$ is the recruitment factor, which is set at 4 and $\langle c\rangle$ is the tide-averaged suspended sediment concentration at the same height from the bed as the tube-ends of the tube-building worms $(2 \mathrm{~cm})$ and $\max \langle c\rangle$ is the maximum tide-averaged suspended sediment concentration at $2 \mathrm{~cm}$ from the bed in the model domain.

After summer, the tube-building worm density during autumn $D_{\text {tube,autumn }}$ is calculated by:

$$
D_{\text {tube,autumn }}=D_{\text {tube,summer }}(r(\langle c\rangle / \max \langle c\rangle)) .
$$

Finally, after autumn all tube-building worms are assumed to disappear and the tube-building worm density during winter $D_{\text {tube, winter }}=0$ ind. $\mathrm{m}^{-2}$. The random seeding of tube-building worm patches starts again after the winter according to Equation (8.2).

\subsection{Model Results}

\subsubsection{Schematized sand wave model}

First, the schematized sand wave model was run for a flow velocity amplitude $U_{M 2}=$ $0.65 \mathrm{~m} \mathrm{~s}^{-1}$, a mean water depth $H_{0}=25 \mathrm{~m}$, a range of different grain sizes $(d=0.20 \mathrm{~mm}$ $-d=0.45 \mathrm{~mm})$ and sand waves with a range of different wave numbers $\left(k=0.4 \cdot 10^{-3}\right.$ $\mathrm{m}^{-1}-k=0.04 \mathrm{~m}^{-1}$, where $\left.k=2 \pi / L\right)$. The setting for flow velocity amplitude, mean water depth and grain size variation resembled a typical North Sea situation for sand wave occurrence (Borsje et al., 2009a; Chapter 4). For every wave number $k$ and grain size $d$, first the growth rate $\gamma_{R}$ was calculated. Next, for a range of wave numbers $k$ and one grain size $d$ the fastest growing mode $L_{F G M}$ was determined. Finally, for a variation in grain sizes $d$ the fastest growing modes $L_{F G M}$ were determined (Figure 8.2A). The fastest growing mode $L_{F G M}$ increased from $310 \mathrm{~m}$ for a grain size $d=0.45$ $\mathrm{mm}$ to a fastest growing mode $L_{F G M}=780 \mathrm{~m}$ for a grain size $d=0.26 \mathrm{~mm}$. For smaller grain sizes, no sand waves were formed due to the dominance of the damping effect of suspended load transport over the build-up effect by the bedload transport as discussed by Borsje et al. (2012b; Chapter 3). The suspended sediment concentrations and hence the damping effect of suspended load transport for a grain size of $d=0.26$ $\mathrm{mm}$ was much larger compared to a grain size $d=0.45 \mathrm{~mm}$. Consequently, the growth 
rate for the fastest growing mode $L_{F G M}$ was larger for the larger grain sizes compared to the smaller grain sizes. For all grain sizes between $d=0.26 \mathrm{~mm}$ and $d=0.45 \mathrm{~mm}$, a finite range of wavelengths showed positive growth rates (Figure 8.2B). Short sand waves showed a relatively large negative growth rate compared to the relative small negative growth rates of the long sand waves (Figure 8.2A).

\subsubsection{Self-organizational sand wave model}

Next, the self-organizational sand wave model was run with the same settings for flow velocity amplitude $U_{M 2}$, water depth $H_{0}$ and grain size variation $d$ as the settings for the schematic sand wave model. For a grain size of $d=0.28 \mathrm{~mm}$, all perturbations with small wavelengths decayed after 5 years, due to the relative large negative growth rates of these perturbations (Figure 8.3A). After 5 years, only the slow growing sand wave lengths and longer perturbations were left. After 20 years of development most perturbations still showed a decrease in amplitude (Figure 8.3A). Similar, for a grain size of $d=0.45 \mathrm{~mm}$ the perturbations with small wavelengths were damped within 5
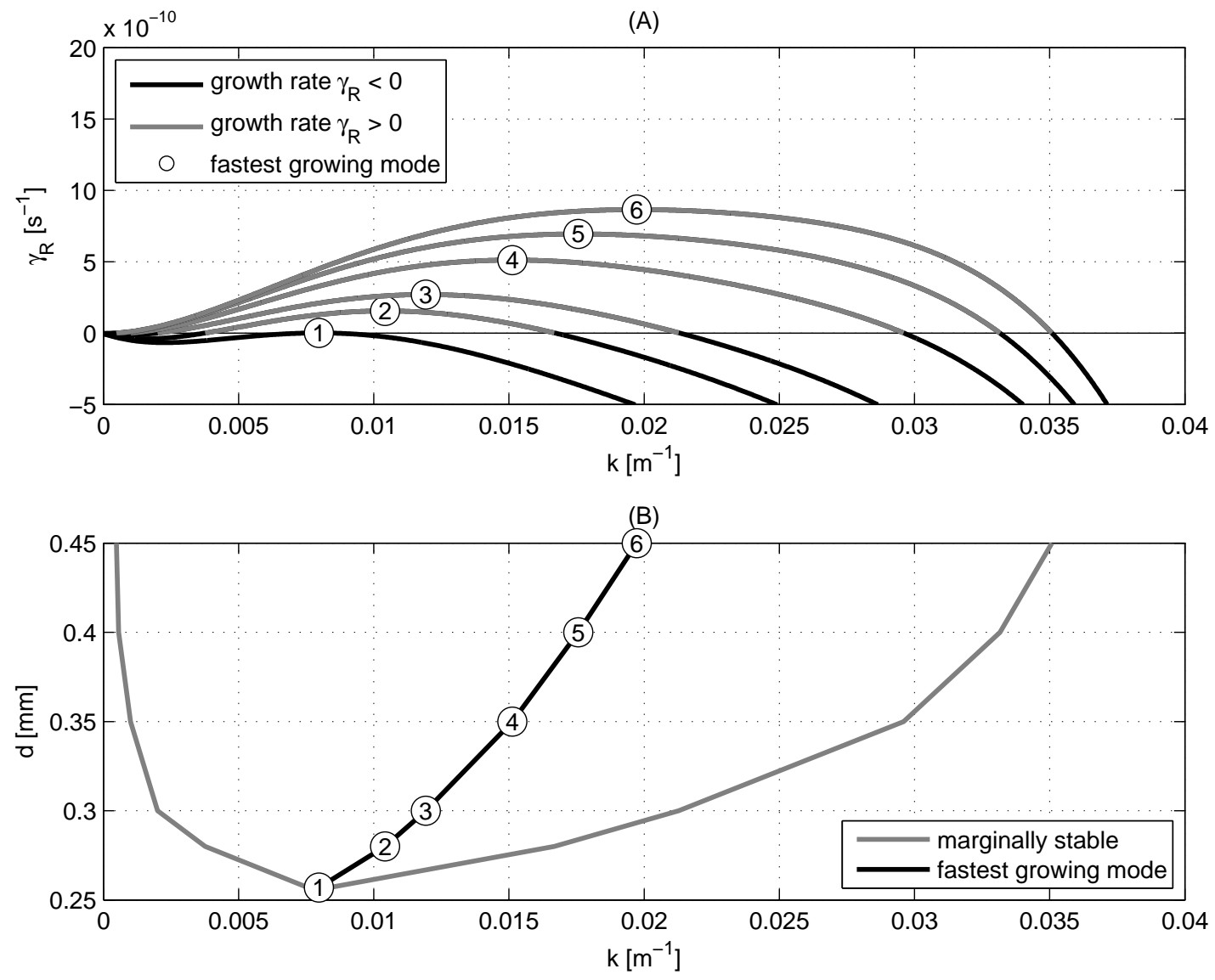

Figure 8.2: Growth rates $\gamma_{R}\left[\mathrm{~s}^{-1}\right]$ for a variation in wave numbers $k\left[\mathrm{~m}^{-1}\right]$ and for a grain size variation between $d=0.26 \mathrm{~mm}(1)$ and $d=0.45 \mathrm{~mm}(6)$. Fastest growing mode $L_{F G M}$ is indicated with a circle (A). Range in fastest growing mode $L_{F G M}$ (black line) and marginally stable conditions (gray line) for a variation in grain size $d(\mathrm{~B})$. Flow velocity amplitude $U_{M 2}=0.65 \mathrm{~m} \mathrm{~s}^{-1}$ and mean water depth $H_{0}=25 \mathrm{~m}$. 
years. However, most perturbations showed an increase in amplitude after 20 years of morphological development (Figure 8.3B).

Next, we studied the growth rate of the perturbations after 1, 5 and 10 years of morphological development for two grain sizes by means of a FFT (Figure 8.4). For a grain size of $d=0.28 \mathrm{~mm}$, almost all perturbations show a negative growth rate. Only for a small range of wave numbers the growth rate was positive. Moreover, the variation in growth rate between the different runs is large, especially after 1 year of morphological changes. Nevertheless, the mean in growth rate for the ten simulations (black line in Figure 8.4C) was comparable to the growth rate for the schematized model for a grain size of $d=0.28 \mathrm{~mm}$ after 10 years (Figure 8.2). For a grain size of $d$ $=0.45 \mathrm{~mm}$, the growth rate was positive for a larger range of wave numbers. Again, the mean in growth rate for the ten simulations (black line in Figure $8.4 \mathrm{~F}$ ) was comparable to the growth rate for the schematized model (Figure 8.2).

The range in dominant wavelengths after 20 years of self-organization for 10 different initial bathymetries and 8 different grain sizes was close to the fastest growing modes $L_{F G M}$ found in the schematic sand wave model (Figure 8.5). The mean of the 10 dominant wavelengths were even within $7 \%$ of the fastest growing modes of the schematized sand wave model.
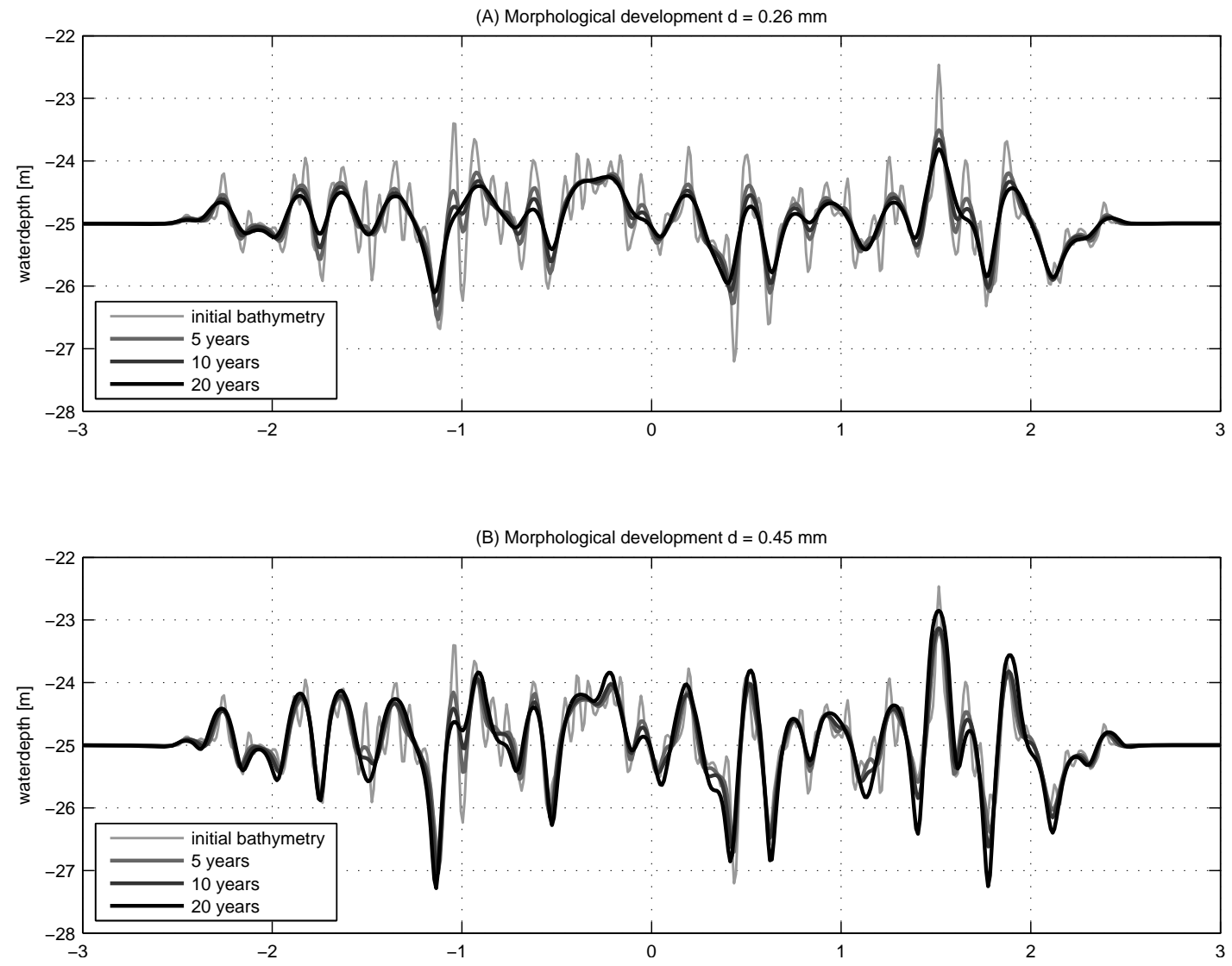

Figure 8.3: Morphological change after 5, 10 and 20 years for a grain size $d=0.26 \mathrm{~mm}$ (A) and a grain size $d=0.45 \mathrm{~mm}(\mathrm{~B})$. Flow velocity amplitude $U_{M 2}=0.65 \mathrm{~m} \mathrm{~s}^{-1}$ and mean water depth $H_{0}=25 \mathrm{~m}$. 

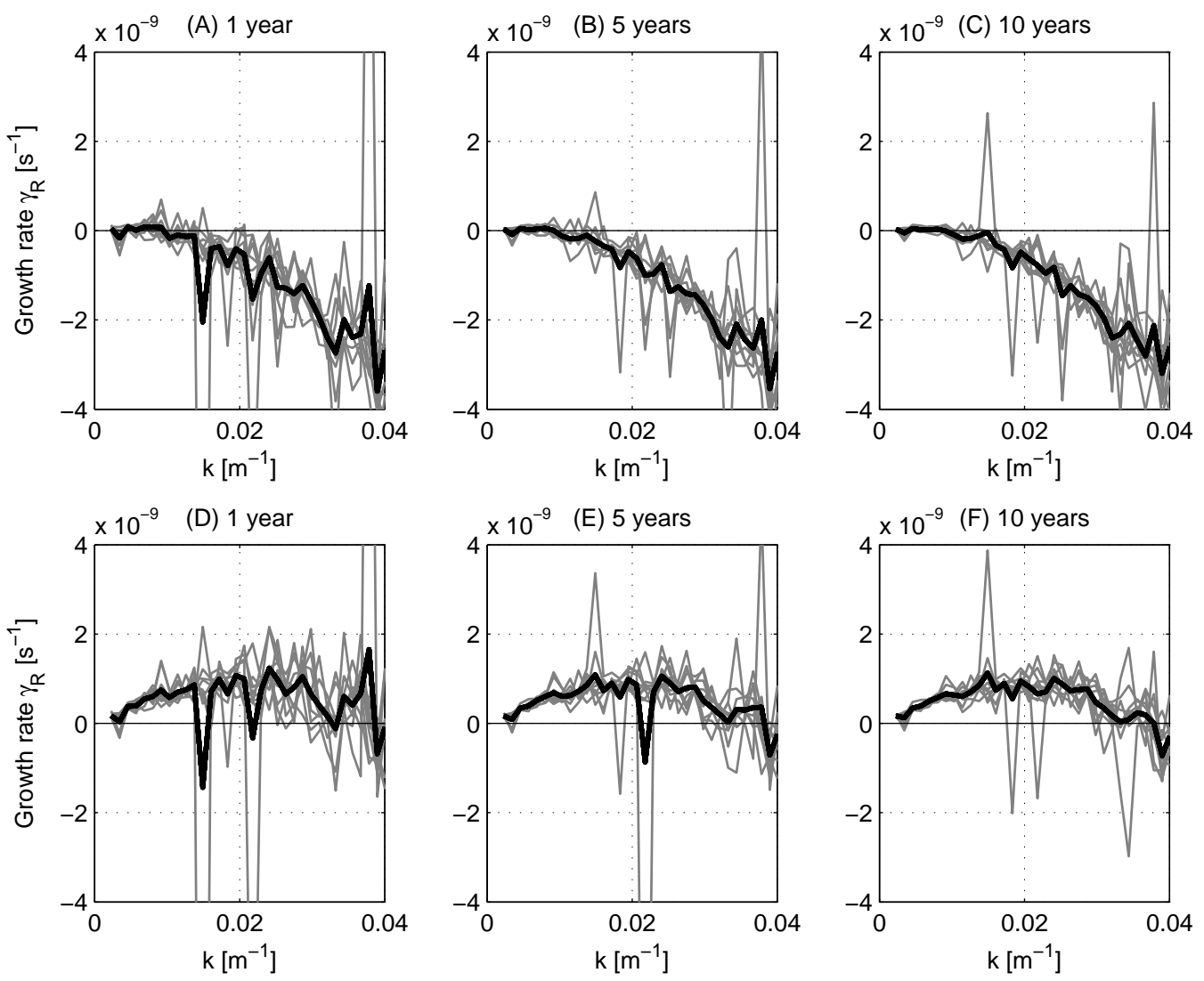

Figure 8.4: Growth rate $\gamma_{R}\left[\mathrm{~s}^{-1}\right]$ for different wave numbers $k\left[\mathrm{~m}^{-1}\right]$ after 1,5 and 10 years of morphological changes for a grain size $d=0.26 \mathrm{~mm}(\mathrm{ABC})$ and a grain size $d$ $=0.45 \mathrm{~mm}(\mathrm{DEF})$. The individual simulations are indicated with a gray line, whereas the mean of the 10 simulations is indicated with a black line. Flow velocity amplitude $U_{M 2}=0.65 \mathrm{~m} \mathrm{~s}^{-1}$ and mean water depth $H_{0}=25 \mathrm{~m}$.

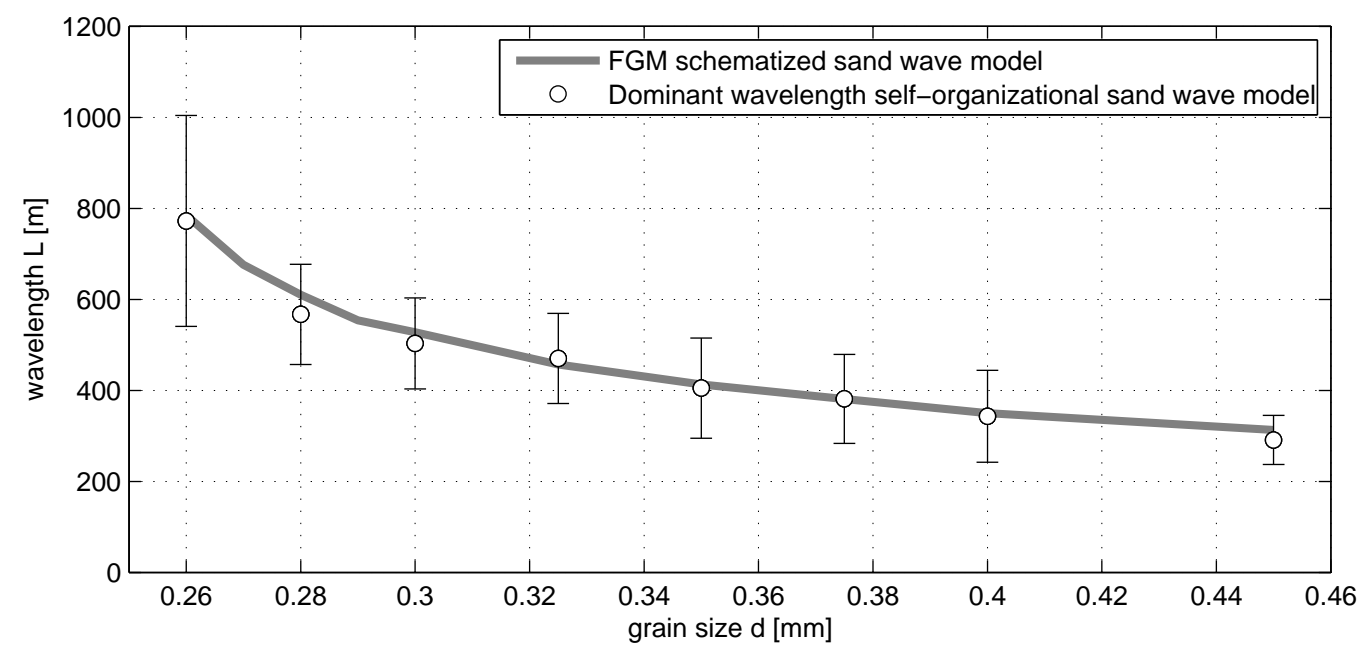

Figure 8.5: Comparison between the fastest growing mode $L_{F G M}$ found in the schematized sand wave model (gray line) and the mean dominant wavelength $L$ found in the self-organizational sand wave model after 20 years (circles) for a variation in grain size $d$. Error bars indicate the $95 \%$ confidence bound. Flow velocity amplitude $U_{M 2}=$ $0.65 \mathrm{~m} \mathrm{~s}^{-1}$ and mean water depth $H_{0}=25 \mathrm{~m}$. 
8.3 Model Results

137
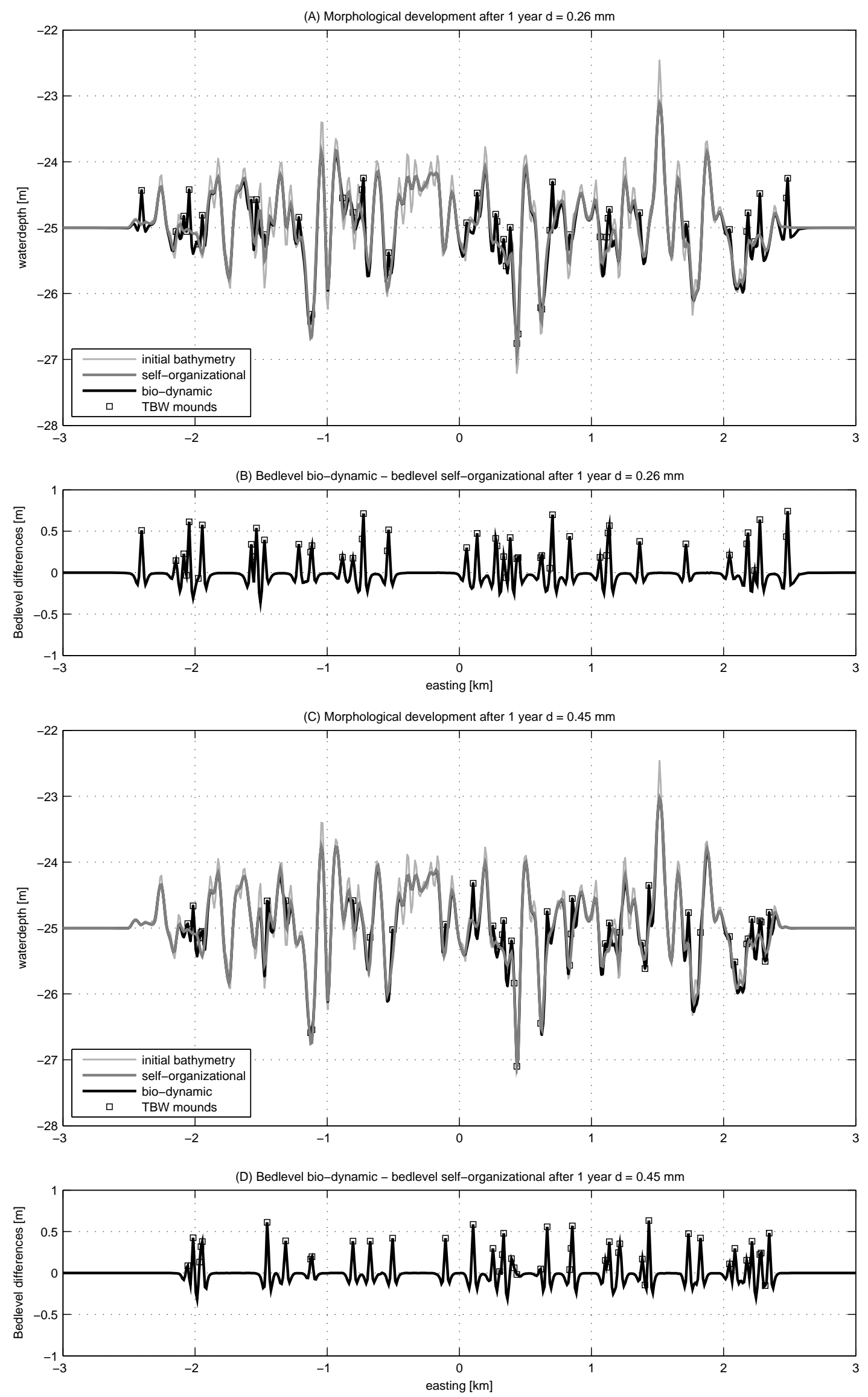
Figure 8.6: (Previous page) Morphological development after 1 year for the selforganizational sand wave model (gray line: free of biological activity) and bio-dynamic sand wave model (black line) for a grain size $d=0.26 \mathrm{~mm}(\mathrm{~A})$ and a grain size $d=0.45$ $\mathrm{mm}(\mathrm{C})$. The initial bathymetry is indicated with the light gray line and the locations of the tube-building worm (TBW) mounds are indicated with squares. Mound heights $[\mathrm{m}]$ are calculated based on the difference between the bed level of the bio-dynamic run and the self-organizational sand wave model after one year for a grain size $d=0.26$ $\mathrm{mm}$ (B) and a grain size $d=0.45 \mathrm{~mm}(\mathrm{D})$. Flow velocity amplitude $U_{M 2}=0.65 \mathrm{~m} \mathrm{~s}^{-1}$ and mean water depth $H_{0}=25 \mathrm{~m}$.

\subsubsection{Bio-dynamic sand wave model}

Finally, the bio-dynamic sand wave model was run with the same settings for flow velocity amplitude $U_{M 2}$ and water depth $H_{0}$ as the settings for the self-organizational and schematic sand wave model. However, only two grain sizes $(d=0.26 \mathrm{~mm}$ and $d$ $=0.45 \mathrm{~mm}$ ) and one initial bathymetry was modeled. Already after one year, mounds were formed by the tube-building worms. The maximum and mean mound height for a grain size $d=0.26 \mathrm{~mm}$ was $74 \mathrm{~cm}$ and $33 \mathrm{~cm}$ respectively (Figure 8.6B). On the other hand, the maximum and mean mound height for a grain size $d=0.45 \mathrm{~mm}$ was $63 \mathrm{~cm}$ and $27 \mathrm{~cm}$ respectively (Figure 8.6D). The slightly larger mound heights for the smaller grain size were caused by the larger total transport rates near the bed. However, the most important factor controlling the mound height is tube density (Borsje et al., 2012c; Chapter 6), which varies between 0 and 130 ind. $\mathrm{m}^{-2}$ for both simulations. At both sides of the mounds, small erosion holes were formed. These holes were also found in the field (Rabaut et al., 2009). At locations where no mounds were formed during the first year, the bed levels were equal for the self-organizational and the biodynamic sand wave model (Figure 8.6), indicating that at the short time-scale (1 year) the tube-building worm patches only influence the bed level changes locally.

After 20 years of morphological development, the mounds formed by tube-building worms prevented the formation of recirculation cells and thereby also prevented the formation of sand waves (compare black line and gray line in Figure 8.7AC). However, at locations where the bed shear stress was relatively high or the suspended sediment concentrations were relatively low, hardly any patch of tube-building worms were found during the 20 years of simulation (Figure 8.7BD). During the 20 years of simulation, $26 \%$ and $35 \%$ of the sand wave field was free of tube-building worm patches for the small $(d=0.26 \mathrm{~mm})$ and the large grain size $(d=0.45 \mathrm{~mm})$ respectively. At locations where no tube-building worms occurred, the bed level in the bio-dynamic model was comparable to the bed level in the self-organizational model, indicating the formation of sand waves (Figure 8.7AC). Nevertheless, the amplitudes of these perturbations were smaller in the bio-dynamic sand wave model than in the self-organizational sand wave model, indicating that at the long time-scale (20 year) the tube-building worm patches influence the bed level changes along the whole sand wave field. 

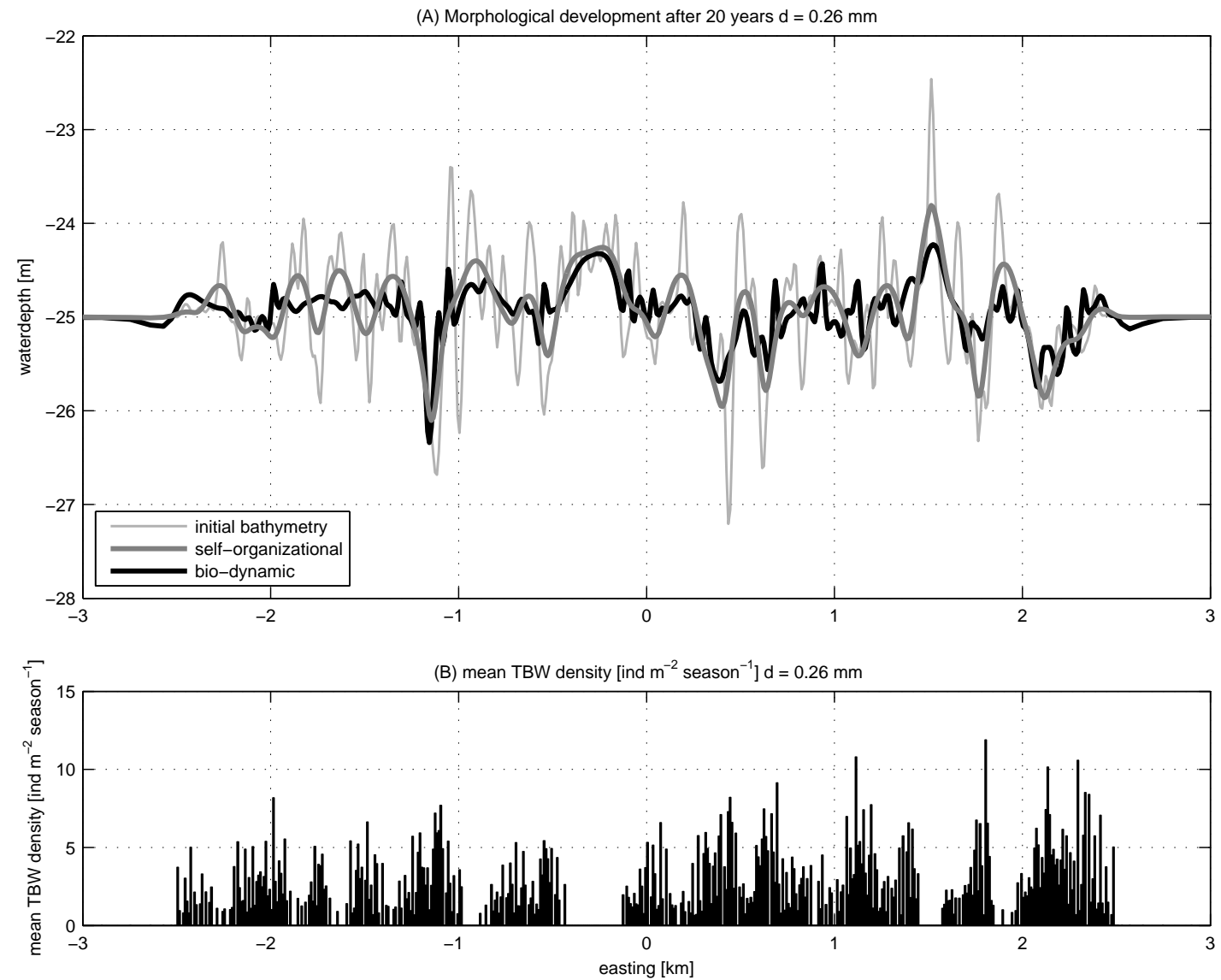

(C) Morphological development after 20 years $\mathrm{d}=0.45 \mathrm{~mm}$
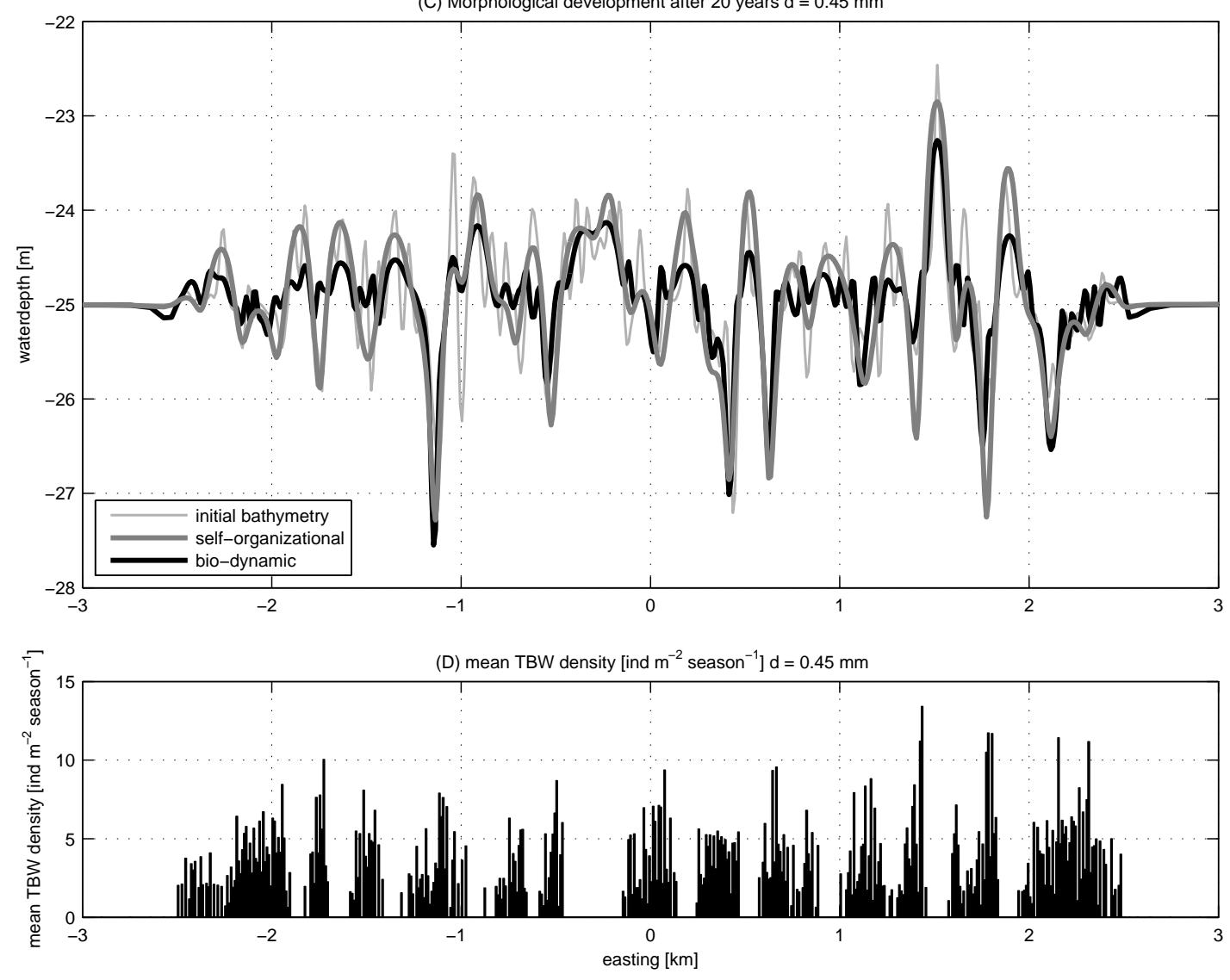
Figure 8.7: (Previous page) Morphological development after 20 years for the selforganizational sand wave model (gray line: free of biological activity) and bio-dynamic sand wave model (black line) for a grain size $d=0.26 \mathrm{~mm}$ (A) and a grain size $d=$ $0.45 \mathrm{~mm}(\mathrm{C})$. The initial bathymetry is indicated with the light gray line. The mean tube-building worm densities [ind. $\mathrm{m}^{-2}$ season $^{-1}$ ] for a grain size $d=0.26 \mathrm{~mm}$ (B) and a grain size $d=0.45 \mathrm{~mm}$ (D) are indicated in bars. Flow velocity amplitude $U_{M 2}=$ $0.65 \mathrm{~m} \mathrm{~s}^{-1}$ and mean water depth $H_{0}=25 \mathrm{~m}$.

\subsection{Discussion}

In this chapter we explored the self-organization in tidal sand wave formation and the role of mounds created by tube-building worms on the self-organization of tidal sand waves. The self-organizational sand wave model is not validated against field data. However, previous model studies with idealized sand wave models already showed that the fastest growing modes in the linear regime found by means of a linear stability analysis were in reasonable agreement with the wavelengths found in the field for sand wave fields (Cherlet et al., 2004; Van Santen et al., 2009). While the dominant wavelengths after self-organization were close to the fastest growing modes in the schematized sand wave model (Figure 8.5), results of this study suggested that the fastest growing mode is a good indicator for the dominant wavelength found after self-organization. Nevertheless, the range in dominant wavelength after self-organization between the ten different simulations is up to $94 \%$ compared to the mean dominant wavelength. As a consequence, both the range in field observations and model outcome should be known in order to compare field observations with model results.

Self-organization in sand wave formation is only modeled in 2DV. In the bio-dynamic sand wave model, 3D effects might influence the outcome of the model. For 3D tubebuilding worm patches, the flow is both deflected over and around a patch of tubebuilding worms, resulting in erosion trenches around the tube-building worm mounds (Rabaut et al., 2009; Borsje et al., 2012c; Chapter 6). Therefore, a 3D simulation will give insight in the impact of trenches created by tube-building worm mounds on the sand wave development and the lateral expansion of tube-building worm patches in time.

In intertidal environments, ecosystem engineering species are shown to form regular patterns on a landscape scale. For example both for mussels (Van de Koppel et al., 2008) and diatoms (Weerman et al., 2010) regular patterns emerge from scaledependent feedback mechanisms, characterized by a local positive feeback and a longer range negative feedback (Rietkerk et al., 2004). Also, for tube-building worms selforganization is observed in the field on a patch scale (Degraer et al., 2008), although on the landscape scale the self-organization in sand wave fields is less obvious, both in the field (Rabaut, 2009) and in the model (Figure 8.7).

The bio-dynamic sand wave model predicted the occurrence of tube-building worm patches on the flanks of sand waves. Also in the field, tube-building worm patches are typically positioned on the flanks of sand waves (Degraer et al., 2008; Rabaut, 2009). Moreover, the maximum densities predicted of 150 ind $\mathrm{m}^{-2}$ also resemble field observations (Holtman et al., 1996), although densities up to 3000 ind. $\mathrm{m}^{-2}$ were recorded in subtidal areas (Rabaut et al. 2008; Degraer et al., 2008). These high densities are measured in much smaller tube-building worm patches than the $10 \mathrm{~m}$ 
wide patches modeled in our bio-dynamic sand wave model. The average patch size measured in the field was $1.37 \mathrm{~m}^{2}$ (Rabaut et al., 2009). To include these small patches in the model, the horizontal resolution in the grid size should be increased. However, this will result in much longer calculation times and is therefore not recommended. Future research should focus on ways to model the impact of the small-scale patches on the large-scale morphodynamics.

Since this study is an explorative study, future research aims to give further insight in the bio-physical interactions in offshore sand wave fields. Therefore, several issues need to be further examined. First of all, by using different initial bathymetries, an analysis on the growth rate of the different wavelengths could be determined for the bio-dynamical sand wave model. For now, only one initial bathymetry is used in the bio-dynamical sand wave model. As shown for the self-organizational sand wave model, the growth rate for a single simulation showed a large scatter, whereas the mean of ten simulations showed a trend (Figure 8.4). By executing an analysis on the growth rate for the bio-dynamic sand wave, the dominant wavelength could be determined. Secondly, the role of a variation in the initial tube-building worm density $D_{\text {tube, initial }}$ (Equation 8.2), the recruitment factor $r$ (Equation 8.3 and 8.4) and the persistence of tubebuilding worm patches during mild winters on the final outcome of the bio-dynamic sand wave model should be studied. Moreover, only 20 years of morphological development is modeled after which morphological developments are still observed. Modeling longer time periods will show the impact of tube-building worms on the equilibrium heights of sand waves. Next, by including residual currents and/or overtides, the impact of tube-building worms on the migration rate of sand waves could be studied. Finally, the impact of human activities like sand extraction and beam trawling in sand wave fields on both the physical and ecological system are important to know. The bio-dynamic sand wave model proposed in this study offers a valuable tool to quantify these impacts.

\subsection{Conclusions}

In this chapter we explored both the physical and bio-physical interactions in tidal sand wave formation in a numerical shallow water model (Delft3D). First, the model was run with an initial bathymetry consisting of random perturbations and free of biological activity. In the first years, all small perturbations were damped, leaving only the perturbations with positive growth rates and the perturbations with long wavelengths which showed small negative growth rates. For the situation where bedload is the dominant transport mode, all long perturbations were damped within 10 years of morphological development and the self-organized sand wave field started to grow in amplitude. However, for the situation near critical conditions of sand wave formation (incipient suspended load dominant case), both the growth rate of the perturbations with intermediate wavelength and the decay rate of the long perturbations were much smaller compared to the bedload dominant case, and after 20 years of morphological development the sand wave field was still decreasing in amplitude. Nevertheless, the range in dominant wavelength found after 20 years of morphological development was close to the fastest growing mode found in the schematized model for both cases.

Next, the bio-dynamical model was run for both the bedload dominant case and the incipient suspended load dominant case, starting with a randomized bed in which mounds were formed by tube-building worms. The heights of these mounds were mostly determined by the tube-building worm density and showed therefore little variation 
between the two runs. However, the area free of tube-building worms during the 20 years simulation period was slightly larger $(35 \%)$ for the bedload dominant case, compared to the suspended load dominant case (26\%), due to less sheltered areas in the bedload dominant case. As a consequence, after 20 years of morphological development the bed was more or less flat with mounds superimposed for the suspended load dominant case, whereas the bedlevel showed alternating mounds and sand waves for the bedload dominant case. 


\section{Chapter 9}

\section{Discussion and Conclusions}

This thesis addresses the interactions between biological and physical processes that determine the formation of the underwater landscape in sandy shelf seas. In combined model studies, flume experiments and field observations it is shown that the species living in the top centimeters of the seabed have a large impact on both the hydrodynamics and sediment dynamics and hence the formation of tidal sand waves.

Before presenting the conclusions of the study (Section 9.2), first the implications of the results presented in this thesis are discussed with a focus on the formation of landscapes (Section 9.1.1), biogeomorphological interactions in landscape formation (Section 9.1.2), validation of biogeomorphological interactions (Section 9.1.3) and the impact of anthropogenic influences on the coupled bio-physical system (Section 9.1.4).

\subsection{Discussion}

\subsubsection{Understanding the formation of landscapes}

In order to identify the relevant processes in the formation of landscapes, two different approaches are known: the scale-concept (De Vriend, 1991) and the self-organization concept (Coco and Murray, 2007). First we will introduce both concepts and next we will apply the insights from this thesis to give recommendations on how to apply both concepts in understanding the formation of landscapes.

In order to explain morphological developments in coastal environments, the scaleconcept introduced by De Vriend (1991) is often applied. De Vriend (1991) suggests that dynamic interactions between driving forces in landscape formation are only possible if processes act on the same temporal and spatial scale. Influences from higher scales are described as boundary conditions, whereas influences from lower scales are considered to be noise. Noise does not mean that these processes are irrelevant, but that only the net effects of these processes are important. For example, a single wave can be seen as noise in coastal evolution. However, the net effect of waves is assumed to trigger the entrainment of sediment and reacts in a dynamic interaction in coastal evolution. On the other hand, sea level rise can be seen as a boundary condition in coastal evolution. Idealized sand wave models are set-up according to the scale-concept: the hydrodynamic processes are strongly schematized (e.g. constant eddy viscosity) and sediment transport is only modeled as bedload. In idealized models it is assumed that spatially and temporally varying turbulence in combination with advanced suspended sediment transport formulations are noise in sand wave formation and therefore not 


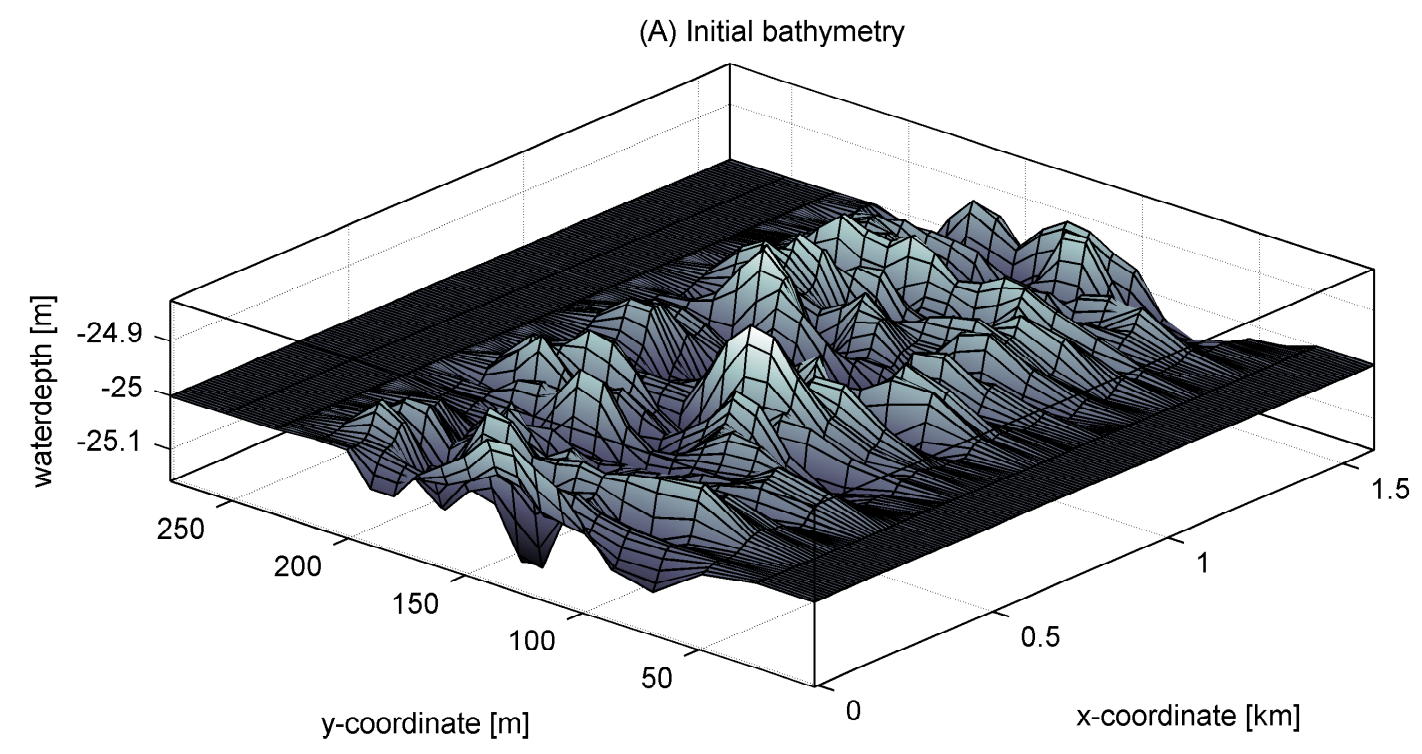

(B) Morphological development after 20 years

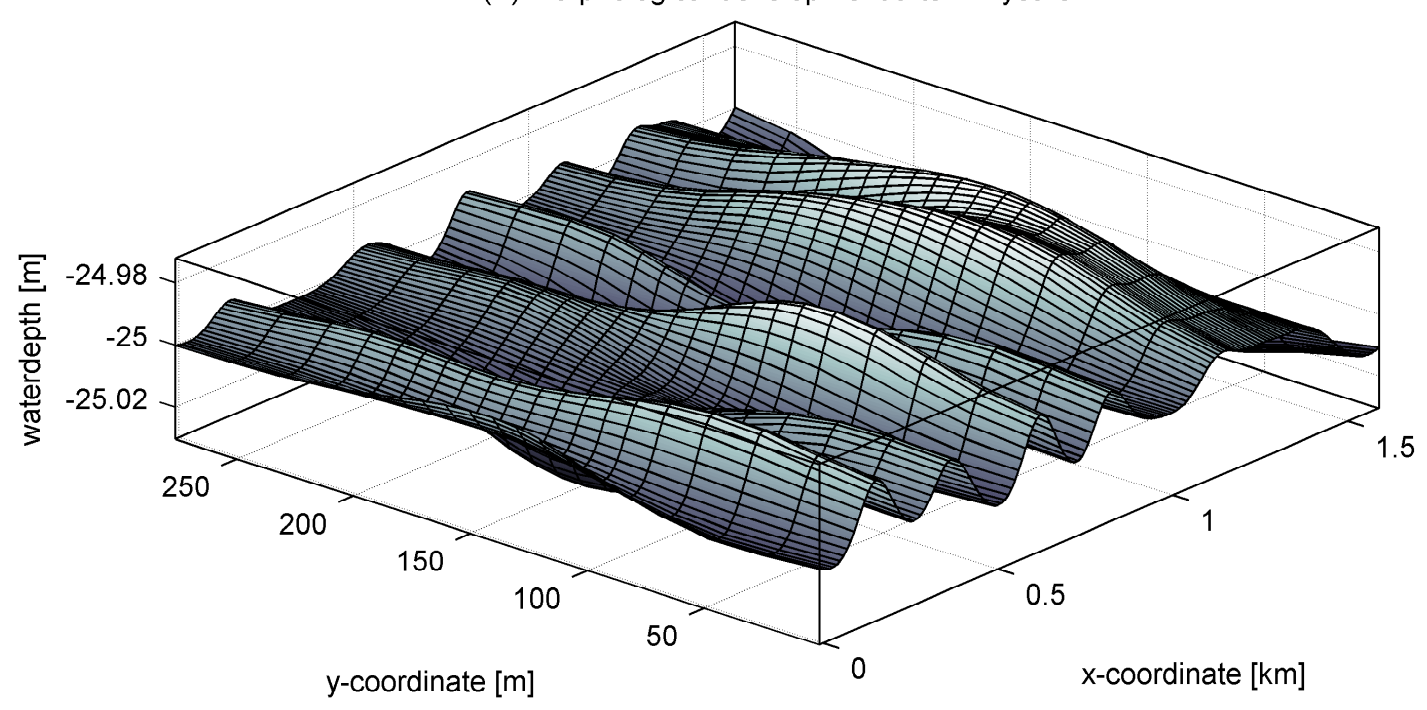

Figure 9.1: Self-organization in a tidal sand wave field. Starting from a bed with random perturbations (top) a regular sand wave field is generated (under) in a time span of 20 years. Flow velocity amplitude $U_{M 2}=0.65 \mathrm{~m} \mathrm{~s}^{-1}$, mean water depth $H_{0}=$ $25 \mathrm{~m}$ and grain size $d=0.35 \mathrm{~mm}$. 
included in the models.

Recently, the concept of self-organization is introduced to explain the formation of landscapes (Coco and Murray, 2007). Self-organization appears to be a common property of geomorphological environments that are characterized by interactions between flow and sediment, including deserts (Werner, 1999; Baas, 2005), rivers (Stølum, 1996; Seminara, 2006) and coasts (Werner and Fink, 1993; Coco et al., 2000). Models involving self-organization show that local interactions between flow and sediment transport can collectively give rise to patterns with large-scale coherence (Coco and Murray, 2007). In this thesis we succeeded for the first time in modeling sand wave formation in a numerical shallow water model (Chapter 2) and with the model we were able to model the self-organization in tidal sand wave fields (Chapter 8). In this thesis, selforganization in sand wave formation is only modeled in 2DV. A first test simulation in 3D confirms that self-organization is also observed in 3D (Figure 9.1). The model used (Delft3D) is a process-based model in which the same physical processes are included as in the idealized sand wave models. However, in the Delft3D model the process formulations are more sophisticated with site-specific characteristics of flow, sediment and bathymetry, spatially and temporally variable turbulence formulations and transport formulations for both bedload and suspended load. An intercomparison between an idealized sand wave model (Van den Berg et al., 2012) and a schematized Delft3D model, in which a constant vertical eddy viscosity profile was imposed and only bedload sediment transport was modeled, showed good agreement (Chapter 2). By imposing a spatially and temporally variable vertical eddy viscosity model $(k-\epsilon$ turbulence model) and modeling sediment transport both as bedload and suspended sediment transport we found negative growth rates for both short and long sand waves, resulting in a finite range of wave numbers which showed growth (Chapter 3). The physical mechanism responsible for decay of short sand waves is the slope effect (Chapter 2), and the decay of long sand waves is induced by suspended sediment transport (Chapter 3).

In conclusion, model simulations with the Delft3D model confirm the hypothesis that a detailed description for both the turbulence structure and sediment transport is required to explain the self-organizational properties of tidal sand wave fields. Nevertheless, the gross properties of sand wave characteristics (wavelength, migration rate, orientation) are fairly well predicted by idealized sand wave models (Cherlet et al., 2004; Van Santen et al., 2009) but the observed variability in wavelength (as found both in the field and in the Delft3D model: Chapter 8) cannot be reproduced in idealized sand wave models (Sterlini et al., 2009). Given the high spatial and temporal resolution required to model sand wave formation in a numerical shallow water model, large computational effort is required. Therefore, using both modeling approaches in a complementary way is recommended: numerical shallow water models for the detailed short-term predictions and idealized models for the long-term qualitative behavior.

\subsubsection{Biogeomorphological interactions in landscape formation}

Biogeomorphological studies are concerned with the two-way coupling between geomorphology and biota. In one direction, geomorphological processes shape the distribution of biota within a landscape, and in the other direction biota modify geomorphological processes (Stallins, 2006). Remarkably, for the biogeomorphological interactions in the underwater landscape only the former coupling is studied. For example, Baptist et al. (2006) showed that richer benthos communities (high density, high diversity) were found in the finer-grained troughs and poorer (low density, low diversity) were found 
at the well-sorted sandy crests, based on sampling in a sand wave area on the Dutch Continental Shelf. In this thesis we studied also the latter coupling: the impact of biota on the geomorphological processes. We showed that mounds created by patches of tube-building worms not only influence the hydrodynamics and sediment dynamics within the patch, but also have a large-scale effect. For example, the footprint of a tube-building worm patch (defined as the area around the patch for which the bed shear stress is influenced by more than $5 \%$ compared to the background bed shear stress divided by the area of the patch) was up to 13 (Chapter 6). Moreover, model simulations showed that when the tube-building worms are absent on the mounds due to recruitment failure, the mound still has an impact on the hydrodynamics and sediment dynamics on the large-scale for a long period (> 100 days: Chapter 6$)$. As already shown for other ecosystem engineering species (Hastings et al., 2007), we showed that the effect of the tube-building worm Lanice conchilega on their environment can reach beyond the spatial scale of their activities, and can persist longer than the life-time of the engineering organism itself. Consequently, biota is able to dynamically interact in the formation of tidal sand waves. Moreover, we were the first to show that the bio-physical interaction is determined by the morphological time scale of the formation of sand waves in relation to the bio-physical time scale of the formation of mounds (Chapter 8). Both in the field of ecology and geomorphology, little attention has been paid to the time scale of formation of geomorphological structures. Therefore, it is recommended to focus in future research on the creation and destruction rates of biogeomorphological structures by other organisms (e.g. flexible worm patches) and also focus on creation and destruction rates of biogeomorphological structures in other environments (e.g. patches of vegetation in intertidal areas and river floodplains).

\subsubsection{Validation of biogeomorphological interactions}

Validation of the results found in this thesis is done on different spatial scales. On the smallest scale, we validated the interaction between tube-building worms and the hydrodynamics in a flume experiment. Moreover, we validated the height of the mound created by tube-building worms with field observations and data found in literature (Chapter 6). On a much larger scale, we validated the impact of benthos on the wavelength and migration rate of sand waves on the scale of a tidal inlet (Chapter 7) and the impact of benthos on the occurrence of sand waves on the scale of the whole North Sea (Chapter 5). However, the results from the two-way coupled model (Chapter 8) are not validated against field observations. To validate these results, both the occurrence of tube-building worm patches and the morphodynamics development should be monitored. The use of very-high resolution $(410 \mathrm{kHz})$ side-scan sonar has proven successful in mapping the patchy distribution of the tube-building worm Lanice conchilega (Degraer et al., 2008) and also the morphodynamics behavior could be determined with the help of side-scan sonar images (Van Dijk et al., 2008). However, by knowing the patchy distribution of tube-building worms and the morphodynamics behavior, only correlative relationships could be determined and no causal relationships could be proven. In order to prove causal relationships, the recovery after a human interference in both the morphological and biological system should be monitored, for example after a shore face nourishment (Borsje et al., 2010), after sand-mining in a sand wave field (Boyd et al., 2005) or after the construction of the Zandmotor in the Netherlands (Mulder and Tonnon, 2010). In general, the benthic community is completely killed after such human interferences (Baptist et al., 2008). Therefore, the morpho- 
logical development at locations where the benthic community recovers relatively fast could be compared with locations where the benthic community recovers relatively slow and consequently causal relationships could be determined.

\subsubsection{Impact of anthropogenic influences on the coupled system}

Systems characterized by strong positive feedbacks between the physical and the biological components can show strongly non-linear behavior and alternative stable states (van de Koppel et al., 2001). In these systems, regime shifts between the different stable states are difficult to reverse and therefore important to understand (Rietkerk et al., 2004). In the case of sand wave formation, we showed that small changes in process parameters (grain size and flow velocity amplitude) resulted in the absence of sand waves (Chapter 3 ) and that benthic organisms are able to influence the grain size and flow velocity amplitude locally, and are therefore able to preserve a flat bed whereas the physical parameters suggest the occurrence of sand waves (Chapter 4). For the Southern Bight of the North Sea, at present characterized by the patchy distribution of ecosystem engineering species and dynamic sand waves, it is an interesting question whether alternative stable states could be caused, at least in part, by the disturbance related to e.g. beam trawling and sand mining. Beam trawling in the Southern North Sea has shown to impact the ecological system in the last century (Callaway et al., 2000) and changes the local morphology for years, while increased sand-mining to protect the coast against an increasing sea level rise may impact on the ecological system in the future (Baptist et al., 2008). Given the absence of beam-trawling in the past, we hypothesize that tube-building worm patches were much more abundant and hence the total area of sand wave fields was much smaller in the Southern North Sea. Future research should test this hypothesis and focus whether impacts on the biological system can change the physical behavior of the bed, which in turn can give feedback on the biology and lead to the occurrence of alternative stable states. 


\subsection{Conclusions}

The objectives of this thesis were as follows: (1) to model tidal sand wave formation in a numerical shallow water model, (2) to quantify the interactions among ecosystem engineering activity, sediment dynamics and hydrodynamics, (3) to implement and validate biogeomorphological models, and (4) to find the dominant processes and timescales in biogeomorphological interactions for tidal sand waves. Five research questions were formulated to achieve these objectives. Answers to these research questions are given below.

Q1. Can tidal sand wave formation be reproduced in a numerical shallow water model (Delft3D), and how do the results of the model compare to the results of idealized sand wave models?

As shown in Chapter 2, the initial stage of tidal sand wave formation has been successfully reproduced in a numerical shallow water model (Delft3D). In order to resolve the tide-averaged residual current over a sand wave, non-reflective lateral boundaries and a high resolution both in time and space were needed. Whereas transport formulations were simplified in idealized sand wave models, the Delft3D model allowed us to include transport formulations in a sophisticated way. Consequently, the Delft3D model has been run with two different turbulence models (Chapter 2): constant vertical eddy viscosity model (often used in idealized sand wave models) and an advanced spatially and temporally variable vertical eddy viscosity model ( $k-\epsilon$ turbulence model). In both model set-ups sediment transport was only modeled as bedload transport. The tide-averaged residual current found in the Delft3D model with constant vertical eddy viscosity showed good agreement with the tide-averaged vertical residual current found in an idealized sand wave model with constant vertical eddy viscosity (Van de Berg et al., 2012). Moreover, the wavelengths predicted by the $k-\epsilon$ turbulence model showed good agreement with field data on sand wave length for different locations in the Southern North Sea, whereas the constant eddy viscosity model overestimates the wavelength of the sand waves considerably.

In Chapter 3, the model has been run with the $k-\epsilon$ turbulence model and sediment transport was modeled both as bedload transport and suspended load transport. Model simulations showed that suspended load transport in combination with the $k-\epsilon$ turbulence model caused very long sand waves to damp, resulting in a finite range of wavelengths of sand waves that experience growth. Moreover, critical conditions for sand wave occurrence were found in the model by varying the flow velocity amplitude and grain size independently. The simulations showed that sand waves were only found when bedload transport is the dominant transport mode. As soon as suspended load transport became the dominant transport regime, sand waves were absent. Field observations on sand wave occurrence also showed that sand waves were only found where bedload transport is the dominant transport mode. 
Q2. What is the potential impact of biogeomorphological influences on tidal sand wave dynamics?

In Chapter 4 we reviewed the available field and flume data for three benthic species that are likely to influence the formation process of sand waves. Three species were selected on the basis of (i) their abundance in shallow shelf seas, (ii) their strong modification of the environment they are living in, and (iii) their contrasting type of feeding and burrowing, and thereby contrasting influence on the sediment dynamics and hydrodynamics. First of all, the sea urchin Echinocardium cordatum feeds from the surface sediment layer and brings fine sediment particles to the deeper sediment and consequently influences the vertical sediment distribution. Secondly, the clam Tellina fabula makes the top layer of the sediment more prone to erosion due to its burrowing and grazing activities. Accordingly, the critical bed shear stress for erosion is reduced. Finally, the tube-building worm Lanice conchilega reduces the near bottom flow. As a result, the ripple height on top of the bed forms is reduced.

Q3. How can the most important ecosystem engineering species be parameterized in order to be incorporated in existing geomorphological models?

A parameterization was proposed in Chapter 5 which links the abundance of the three dominant ecosystem engineering species (Q2) to physical properties of the seabed (vertical sediment distribution, the critical bed shear stress and the ripple height). Inclusion of the parameterization in an idealized sand wave model (Hulscher, 1996) showed that animal effects can be sufficient to change the model behavior from presence to absence of sand waves in considerable parts of the North Sea off the Holland coast. This was mainly due to the stabilizing effect of the tube-building worm Lanice conchilega.

Moreover, a model tool was set-up in which the interaction among the hydrodynamics, sediment dynamics and patches of tube-building worms Lanice conchilega were quantified (Chapter 6). This model tool explicitly accounted for the influence of cylindrical structures on drag and turbulence by an extra source term of friction force in the momentum equation and an extra source term of Total Kinetic Energy (TKE) and turbulent energy dissipation in the turbulence closure model (Dijkstra and Uittenbogaard, 2011). The model tool was validated with flume experiments, in which tube-building worms were mimicked with straws and the flow adaptation in front and within a patch was quantified for varying tube densities. The modeled equilibrium mound height increased with the tube length of the tube-building worms and with population density, but was only little affected by the strength of the tidal current. 
Q4. Can the biogeomorphological models (Q3) be applied to different test cases, and how do the results of the models compare to field observations?

Tree different test cases were selected to apply the biogeomorphological models (Q3). In the first test case, an idealized biogeomorphological sand wave model was applied in the Dutch part of the North Sea focusing on the occurrence of sand waves (Chapter 5). In the second case, a biogeomorphological model tool was applied in the Belgian part of the North Sea focusing on the mound height created by patches of tube-building worms (Chapter 6). In the third test case (Chapter 7), we demonstrated in an idealized biogeomorphological sand wave model that variations in biological and physical processes are capable of causing the seasonal variation in migration rate and wavelength of sand waves in the Marsdiep inlet (The Netherlands). For all cases, the outcome of the biogeomorphological models showed good agreement with field observations.

Q5. By extending a biogeomorphological tidal sand wave model (Q3) with the feedback from the bed evolution, hydrodynamics and sediment transport to ecosystem engineering activity, what are the dominant processes and time scales in this two-way coupled biogeomorphodynamic model?

To study the two-way coupling between biota and physical forces in sand wave formation we combined the numerical shallow water model (Q1) with the tube-building worm tool (Q3) (Chapter 8). The initial bathymetry in the biogeomorphological model consisted of randomized perturbations and the seasonal and patchy distribution for tube-building worms was prescribed by a simple tube-building worm growth model. First the self-organization of a tidal sand wave field free of biological activity was studied to determine the dominant processes and timescales of sand wave formation. Already after 5 years of morphological development all perturbations with small wavelengths were damped and after 20 years of morphological development a dominant wavelength was found which matches the fastest growing mode in the schematized sand wave model (Q1) very well. In the bio-dynamic model, every year tube-building worm mounds were formed at sheltered locations which influenced the morphological development already after one year locally. After 20 years of growth and decay of tube-building worm mounds, the morphological development along the whole sand wave field was influenced. At locations near the critical conditions of sand wave formation (Q1), tube-building worm patches were able to form a landscape which consisted of tubebuilding worm mounds. However, at locations in the bedload regime, the landscape consisted of tube-building worm mounds alternated with tidal sand waves. 


\section{Bibliography}

Acda, T., De Munnik, P., 1997. Tien seconden. Acda en De Munnink (CD Album), In Dutch.

Andersen, T.J., Jensen, K.T., Lund-Hansen, L., Mouritsen, K.N., Pejrup, M., 2002. Enhanced erodibility of fine-grained marine sediments by Hydrobia ulvae. Journal of Sea Research 48, 51-58.

Apotsos, A., Gelfenbaum, G., Jaffe, B., 2011. Process based modeling of tsunami inundation and sediment transport. Journal of Geophysical Research 116, F01006.

Austen, I., Andersen, T.J., Edelvang, K., 1999. The influence of benthic diatoms and invertebrates on the erodibility of an intertidal mudflat, the Danish Wadden Sea. Estuarine, Coastal and Shelf Science 49, 99-111.

Baas, A.C.W., 2005. Chaos, formation and behavior of aeolian streamers. Journal of Geophysical Research, F03011.

Baas, A.C.W., Nield, J.M., 2007. Modelling vegetated dune landscapes. Geophysical Research Letters 34, L06405.

Bagnold, R.A., 1956. The flow of cohesionless grains in fluids. Proc. Royal Soc. Philos. Trans., London, vol. 249, pp. 71-81.

Baptist, M.J., Van Dalfsen, J., Weber, A., Passchier, S., Van Heteren, S., 2006. The distribution of macrozoobenthos in the Southern North Sea in relation to mesoscale bedforms. Estuarine, Coastal and Shelf Science 68, 538-546.

Baptist, M.J., Tamis, J.E., Borsje, B.W., Van der Werf, J.J., 2008. Review of the geomorphological, benthic ecological and biogeomorphological effects of nourishments on the shoreface and surf zone of the Dutch coast. Report IMARES C113/08, Deltares Z4582.50.

Barrio Froján, C.R.S., Boyd, S.E., Cooper, K.M., Eggleteon, J.D., Ware, Z., 2008. Long-term benthic responses to sustained disturbance by aggregate extraction in an area off the east coast of the United Kingdom. Estuarine, Coastal and Shelf Science 79, 204-212.

Baumfalk, Y.A., 1979. Heterogeneous grain size distribution in tidal flat sediment caused by bioturbation activity of Arenicola marine (polychaeta). Netherlands Journal of Sea Research 13, 428-440.

Besio, G., Blondeaux, P., Frisina, P. 2003. A note on tidally generated sand waves. Journal of Fluid Mechanics 485, 171-190. 
Besio, G., Blondeaux, P., Brocchini, M., Vittori, G., 2004. On the modelling of sand wave migration. Journal of Geophysical Research 109, 1-13.

Besio, G., Blondeaux, P., Vittori, G., 2006. On the formation of sand waves and sand banks. Journal of Fluid Mechanics 557, 1-27.

Besio, G., Blondeaux, P., Brocchini, M., Hulscher, S.J.M.H., Idier, D., Knaapen, M.A.F., Németh, A.A., Roos, P.C., Vittori, G., 2008. The morphodynamics of tidal sandwaves: a model overview. Coastal Engineering 55, 657-670.

Beukema, J.J., 1979. Biomass and species richness of the macrobenthic animals living on a tidal flat area in the Dutch Wadden Sea: effects of a severe winter. Netherlands Journal of Sea Research 13, 203-223.

Blondaux, P., 2001. Mechanics of coastal forms. Annual Review of Fluid Mechanics $33,339-370$.

Blondeaux, P., Vittori G., 2005a. Flow and sediment transport induced by tide propagation. 1. The flat bottom case. Journal of Geophysical Research 110, C07020.

Blondeaux, P., Vittori, G., 2005b. Flow and sediment transport induced by tide propagation. 2. The wavy bottom case. Journal of Geophysical Research 110, C08003.

Bobertz, B., Harff, J., Bohling, B., 2009. Parameterisation of clastic sediments including benthic structures. Journal of Marine Systems 75, 371-381.

Borja, A., Franco, J., Pérez, V., 2000. A marine biotic index to establish the ecological quality of soft-bottom benthos within European estuarine and coastal environments. Marine Pollution Bulletin 12, 1100-1114.

Borsje, B.W., De Vries, M.B., Hulscher, S.J.M.H., De Boer, G.J, 2008a. Modeling large scale cohesive sediment transport with the inclusion of biological activity. Estuarine, Coastal and Shelf Science 78, 468-480.

Borsje, B.W., Besio, G., Blondeaux, P., Hulscher, S.J.M.H., Vittori, G., 2008b. Exploring biological influence on offshore sandwave length. Marine and River Dune Dynamic III, International Workshop, April 1-3 2008, Leeds. Parsons, D.R., Garlan, T., Best, J.L. (Eds), pp 31-38.

Borsje, B.W., De Vries, M.B., Bouma, T.J., Besio, G., Hulscher, S.J.M.H., Herman, P.M.J., 2009a. Modelling biogeomorphological influences for offshore sandwaves. Continental Shelf Research 29, 1289-1301.

Borsje, B.W., Hulscher, S.J.M.H., Herman, P.M.J., De Vries, M.B. 2009b. On the parameterization of biological influences on offshore sandwave dynamics. Ocean Dynamics 59, 659-670.

Borsje, B.W., Buijsman, M.C., Besio, G., De Vries, M.B., Hulscher, S.J.M.H., Herman, P.M.J., Ridderinkhof, H., 2009c. On the modelling of bio-physical influences on seasonal variation in sandwave characteristics. Journal of Coastal Research 56, 698-702. 
Borsje, B.W., Van der Werf, J.J., Kruijt, M.A., Hulscher, S.J.M.H., Herman, P.M.J., 2010. Modeling biogeomorphological interactions for the Dutch sandy coast. Submitted for the 32nd International Conference on Coastal Engineering (ICCE), Shanghai, China.

Borsje, B.W., Roos, P.C., Kranenburg, W.M., Hulscher, S.J.M.H., 2012a. Modeling sandwave evolution in a numerical shallow water model, the role of turbulence. Under review.

Borsje, B.W., Kranenburg, W.M., Roos, P.C., Jordan, M., Hulscher, S.J.M.H., 2012b. The role of suspended sediment in the occurrence of tidal sand waves.Under review.

Borsje, B.W., Bouma, T.J., Rabaut, M., Herman, P.M.J., Hulscher, S.J.M.H., 2012c. Creation and degradation rates of biogeomorphological structures: a study on the tube-building polychaete Lanice conchilega. Under review.

Bouma, T.J., De Vries, M.B., Low, E., Peralta, G., Tanczos, I.C., Van de Koppel, J., Herman, P.M.J., 2005. Trade-offs related to ecosystem-engineering: a case study on stiffness of emerging macrophytes. Ecology 86, 2187-2199.

Bouma, T.J., Van Duren, L.A., Temmerman, S., Claverie, T., Blanco-Garcia, A., Ysebaert, T., Herman, P.M.J., 2007. Spatial flow and sedimentation patterns within patch of epibenthic structures: combining field, flume and modeling experiments. Continental Shelf Research 27, 1020-1045.

Bouma, T.J., De Vries, M.B., Herman, P.M.J., 2010. Comparing Ecosystem engineering efficiency of 2 plant species with contrasting growth strategies. Ecology 91, 2696-2704.

Boyd, S.E., Limpenny, D.S., Rees, H.L., Cooper, K.M., 2005. The effects of marine sand and gravel extraction on the macrobenthos at a commercial dredging site (results 6 years post-dredging). ICES Journal of Marine Science 62, 145-162.

Buhr, K.J., 1976. Suspension-feeding and assimilation efficiency in Lanice conchilega (Polychaeta). Marine Biology 38, 373-383.

Buijsman, M.C., Ridderinkhof, H., 2007. Long-term ferry-ADCP observations of tidal currents in the Marsdiep inlet. Journal of Sea Research 57, 237-256.

Buijsman, M.C., Ridderinkhof, H., 2008a. Long-term evolution of sandwaves in the Marsdiep inlet. I: high-resolution observations. Continental Shelf Research 28, 1190-1201.

Buijsman, M.C., Ridderinkhof, H., 2008b. Long-term evolution of sandwaves in the Marsdiep inlet. II: Relation to hydrodynamics. Continental Shelf Research 28, 1202-1215.

Burchard, H., Craig, P.D., Gemmrich, J.R., Van Haren, H., Mathieu, P.-P., Meier, H.E.M., Nimmo Smith,W.A.M., Prandke, H., Rippeth, T.P., Skyllingstad, E.D., Smyth,W.D., Welsh, D.J.S., Wijesekera, H.W., 2008. Observational and numerical modeling methods for quantifying coastal ocean turbulence and mixing. Progress in Oceanography 76, 399-442. 
Burone, L., Muniz, P., Pires-Vanin, A.M.S., Rodrigues, M., 2003. Spatial distribution of organic matter in the surface sediments of Ubatuba Bay (Southesatern -Brazil). Annals of the Brazilian Academy of Sciences 75, 77-90.

Callaway, R., Engelhard, G.H., Dann, J., Cotter, J., Rumohr, H., 2007. A century of North Sea epibenthos and trawling: comparison between 1902-1912, 1982-1985 and 2000. Marine Ecology Progress Series 346, 27-43.

Carey, D.A., 1987. Sedimentological effects and palaeoecological implications of the tube-building polychaete Lanice conchilega Pallas. Sedimentology 34, 49-66.

Cherlet, J., Besio, G., Blondeaux, P. Van Lancker, V., Verfaillie, E., Vittori, G., 2007. Modeling sand wave characteristics on the Belgian Continental Shelf and in the Calais-Dover Strait. Journal of Geophysical Research, C06002,

Coco, G., Huntley, D.A., O‘Hare, T.J., 2000. Investigation of a self-organisation model for beach cusp formation and development. Journal of Geophysical Research 105, 21991-22002.

Coco, G., Murray, A.B., 2007. Patterns in the sand: From forcing templates to selforganization. Geomorphology 91, 271-290.

Colombini, M., 2004. Revisiting the linear theory of sand dune formation. Journal of Fluid Mechanics 502, 1-16.

Corenblit, D., Baas, A.C.W., Bornette, G., Darrozes, J., Delmotte, S., Francis, R.A., Gurnell, A.M., Julien, F., Naiman, R.J., Steiger, J., 2011. Feedbacks between geomorphology and biota controlling Earth surface processes and landforms: A review of foundation concepts and current understandings. Earth-Science Reviews 106, 307-311.

Cramer, A., Duineveld, G.C.A., Jenness, M.I., 1991. Observations on spatial distribution, metabolism and feeding strategy of Echinocardium cordatum (Pennant) (Echinodermata) and the implications for its energy budget. In: Cramer, A., (Ed.), Benthic Metabolic Activity at Frontal Systems in the North Sea. PhD Thesis, University of Amsterdam, Amsterdam, pp. 63-74.

D‘Alpaos, A., Lanzoni, S., Marani, M., Bonornetto, A., Cecconi, G., Rinaldo, A., 2007. Spontaneous tidal network formation within a constructed salt marsh: observations and morphodynamic modelling. Geomorphology 91, 186-197.

Daniell, J.J., Harris, P.T., Hughes, M.G., Hemer, M., Heap, A., 2008. The potential impact of bedform migration on seagrass communities in Torres Strait, northern Australia. Continental Shelf Research 28, 2188-2202.

De Deckere, E.M.G.T., Tolhurst, T.J., De Brouwer, J.F.C., 2001. Destabilization of cohesive intertidal sediments by infauna. Estuarine, Coastal and Shelf Science 53, 665-669.

De Vriend, H.J., 1991. Mathematical modelling and large-scale coastal behaviour. Part 1: physical processes. Journal of Hydraulic Research 29, 727-740.

Dean R.B., 1974. AERO Report 74-11. Imperial College, London. 
Degraer, S., Van Lancker, V., Moerkerke, G., Van Hoey, G., Vincx, M., Jacobs, P., Henriet, J.P., 2002. Intensive evaluation of the evolution of a protected benthic habitat: HABITAT. Final report 01/02. Federal Office for Scientific, Technical and Cultural Affairs (OSTC).

Degraer, S., Volckaert, A., Vincx, M., 2003. Macrobenthic zonation patterns along a morphodynamical continuum of macrotidal, low tide bar/rip and ultra-dissipative sandy beaches. Estuarine, Coastal and Shelf Science 56, 459-468.

Degraer, S., Van Lancker, V., Moerkerke, G., Van Hoey, G., Vanstaen, K., Vincx, M., Henriet, J.P., 2003. Evaluation of the ecological value of the foreshore: habitat-model and macrobenthic side-scan sonar interpretation: extension along the Belgian Coastal Zone. Final report. Ministry of the Flemish Community, Environment and Infrastructure. Department. Waterways and Marine Affairs Administration, Coastal Waterways.

Degraer, S., Moerkerke, G., Rabaut, M., Van Hoey, G., Du Four, I., Vincx, M., Henriet, J.P., Van Lancker, V. 2008. Very high resolution side-scan sonar mapping of biogenic reefs of the tube-worm Lanice conchilega. Remote Sensing of Environment 112, 3323-3328.

Degraer, S., Verfaillie, E., Willems, W., Adriaens, E., Vincx, M., Van Lancker, V., 2008. Habiat suitability modelling as a mapping tool for macrobenthic communities: An example from the Belgian part of the North Sea. Continental Shelf Research 28, 369-379.

Deltares, 2012. User manual Delft-3D FLOW, Deltares (www.deltares.nl), Delft, The Netherlands.

Dijkstra, J.T., Uittenbogaard R.E., 2010. Modeling the interaction between flow and highly flexible aquatic vegetation. Water Resources Research 46, W12547.

Dodd, N., Blondeaux, P., Calvete, D., De Swart, H., Falques, A., Hulscher, S.J.M.H., Rozynski, G., Vittori, G., 2003. The use of stability methods for understanding the morphodynamical behaviour of coastal systems. Journal of Coastal Research $19,849-865$.

Dorst, L.L., Roos, P.C., Hulscher S.J.M.H., Lindenbergh, R.C., 2009. The estimation of sea floor dynamics from bathymetric surveys of a sand wave area. Journal of Applied Geodesy 3(3), 97-120.

Dyer, K.R., Huntley, D.A., 1999. The origin, classification and modeling of sandbanks and ridges. Continental Shelf Research 19, 1285-1330.

Eckman, J.E., Nowell, A.R.M., Jumars, P.A., 1981. Sediment destabilization by animal tubes. Journal of Marine Research 39, 361-374.

Ernstsen, V.B., Noormets, R., Winter, C., Hebbeln, D., Bartholoma, A., Flemming, B.W., Bartholdy, J., 2005. Development of subaqueous barchanoid-shaped dunes due to lateral grain size variability in a tidal inlet channel of the Danish Wadden Sea. Journal of Geophysical Research 110, F04S08. 
Featherstone, R.P., Risk, M.J., 1977. Effect of tube-building polychaetes on intertidal sediments of the Minas Basin, Bay of Fundy. Journal of Sedimentary Petrology $47,446-450$.

Fredsøe, J., Deigaard, R., 1992. Mechanics of Coastal Sediment Transport. World Scientific.

Friedrichs, M., 1997. Report about the characteristics of the NIOO-CEMO flume system-pilot study. NIOO-CEMO, NI00 rapporten 1997-6, Yerseke.

Friedrichs, M., Graf, G., Springer, B., 2000. Skimming flow induced over a simulated polychaete tube lawn at low population densities. Marine Ecology Progress Series 192, 219-228.

Friedrichs, M., Graf, G., 2009. Characteristic flow patterns generated by macrozoobenthic structures. Journal of Marine Systems 75, 348-359.

Friedrichs, M., Leipe, T., Peine, F., Graf, G., 2009. Impact of macrozoobenthic structures on near-bed sediment fluxes. Journal of Marine Systems 75, 336-347.

Gerkema, T., 2000. A linear stability analysis of tidally generated sand waves. Journal of Fluid Mechanics 417, 303-322.

Gilbert, F., Hulth, S., Grossi, V., Poggiale, J.C., Desrosiers, G., Rosenberg, R., Gerino, M., Francois-Carcaillet, F., Michaud, E., Stora, G., 2007. Sediment reworking by marine benthic species from the Gullmar Fjord (Western Sweden): Importance of faunal biovolume. Journal of Experimental Marine Biology and Ecology 348, $133-144$.

Godet, L., Fournier, J., Jaffre, M., Desroy, N., 2011. Influence of stability and fragmentation of a worm-reef on benthic macrofauna. Estuarine, Coastal and Shelf Science 92, 472-479.

Graf, G., Rosenberg, R., 1997. Bioresuspension and biodeposition: a review. Journal of Marine Systems 11, 269-278.

Gutierrez, J.L., Jones, C.G., 2006. Physical ecosystem engineers as agents of biogeochemical heterogeneity. Bioscience 56, 227-236.

Hartmann-Schröder, G., 1971. Annelida, Borstenwürmer, Polychaete. Gustav Fischer Verlag, Jena., 594 pp.

Hastings, A., Byers, J.E., Crooks, J.A., Cuddington, K., Jones, C.G., Lambrinos, J.G., Talley, T.S., Wilson, W.G., 2007. Ecosystem engineering in space and time. Ecological Letters 10, 153-164.

Heip, C., Basford, D., Craeymeersch, J.A., Dewarumez, J.-M., Dörjes, J., De Wilde, P., Duineveld, G., Eleftheriou, A., Herman, P.M.J., Niermann, U., Kingston, P., Künitzer, A., Rachor, E., Rumohr, H., Soetaert, K., Soltwedel, T., 1992. Trends in biomass, density and diversity of North Sea macrofauna. Journal of Marine Science 49, 13-22. 
Herman, P.M.J., Middelburg, J.J., Heip, C.H.R., 2001. Benthic community structure and sediment processes on an intertidal flat: results from the ECOFLAT project. Continental Shelf Research 21, 2055-2071.

Heuers, J., Jaklin, S., 1999. Initial settlement of Lanice conchilega. Senckenbergiana marit. 29, 6769.

Hirano, M., 1971. River bed degradation with armouring. Proceedings, Jap. Soc. of Civil Eng. 195, 55-65.

Holthe, T., 1986. Polychaeta Terebellomorpha. Marine invertebrates of Scandinavia, No. 7. Norwegian University Press. Oslo, 194 pp.

Holtmann, S.E., Groenewold, A., Schrader, K.H.M., Asjes, J., Craeymeersch, J.A., Duineveld, G.C.A., Van Bostelen, A.J., Van der Meer, J., 1996. Atlas of the zoobenthos of the Dutch Continental Shelf. Ministry of Transport, Public Works and Water Management, North Sea Directorate, Rijswijk, 244 pp.

Hulscher, S.J.M.H., 1996. Tidal-induced large-scale regular bed form patterns in a three-dimensional shallow water model. Journal of Geophysical Research $101 \mathrm{C} 9$.

Hulscher, S.J.M.H., Roelvink, J.A., 1997. Comparison between predicted and observed large-scale sea bed features in the southern North Sea. Technical Report, University of Twente.

Hulscher, S.J.M.H., Van den Brink, G.M. 2001. Comparison between predicted and observed sand waves and sand banks in the North Sea. Journal of Geophysical Research C5 106, 9327-9338.

Huntley, D.A., Huthnance, J.M., Collins, M.B., Liu, C.L., Nicholls, R.J., Hewitson, C.,1993. Hydrodynamics and sediment dynamics of North Sea sand waves and sand banks, Philos. Trans. R. Soc. London, Ser. A, 343, 461-474.

Huthnance, J., 1982, On one mechanism forming linear sandbanks. Estuarine Coastal and Shelf Science 14, 79-99.

Jones, C.G., Lawton, J.H., Shachak, M., 1994. Organisms as ecosystem engineers. Oikos 69, 373-386.

Jones, C.G., Lawton, J.H., Shachak, M., 1997. Positive and negative effects of organisms as physical ecosystem engineers. Ecology 78, 1946-1957.

Jones, C.G., Gutierrez, J.L., Byers, J.E., Crooks, J.A., Lambrinos, J.G., Talley, T.S., 2010. A framework for understanding physical ecosystem engineering by organisms. Oikos 119, 1862-1869.

Jones, C.G., 2012. Ecosystem engineers and geomorphological signatures in landscapes. Geomorphology, in press.

Künitzer, A., Duineveld, G.C.A., Basford, D., Dewarumez, J.M., Dörjes, J., Eleftheriou, A., Heip, C., Herman, P.M.J., Kingston, P., Niermann, U., Rumohr, H., de Wilde, P.A.W.J., 1992. The benthic infauna of the North Sea: species distribution and assemblages. Journal of Marine Science 49, 127-143. 
Katoh, K., Kume, H., Kuroki, K., Hasegawa, J., 1998. The development of sand waves and the maintenance of navigation channels in the Bisanteto Sea, in Proceedings of International Conference on Coastal Engineering, 3490-3502.

Kirwan, M.L., Murray, A.B., 2007. A coupled geomorphic and ecological model of tidal marsh evolution, PNAS 104, 6118-6122.

Knaapen, M.A.F., Hulscher, S.J.M.H., 2002. Regeneration of sand waves after dredging. Coastal Engineering 46, 277-289.

Knaapen, M.A.F., Holzhauer, H., Hulscher, S.J.M.H., Baptist, M.J., De Vries, M.B., Van Ledden, M., 2003. On the modelling of biological effects on morphology in estuaries and seas. In: Sánchez-Arcilla, A., Bateman, A. (Eds.), Proceedings of the Third IAHR Symposium on River, Coastal and Estuarine Morphodynamics Conference. IAHR, Barcelona, Spain, pp. 773-783.

Komarova, N.L., Hulscher, S.J.M.H., 2000. Linear instability mechanisms for sand wave formation. Journal of Fluid Mechanics 413, 219-246.

Le Hir, P., Monbet, Y., Orvain, F., 2007. Sediment erodability in sediment transport modelling: can we account for biota effects? Continental Shelf Research 27, 11161142 .

Lesser, G., Roelvink, J., Van Kester, J., Stelling, G., 2004. Development and validation of a three-dimensional morphological model. Coastal Engineering 51, 883-915.

Lohrer, A.M., Thrush, S., F., Hunt, L., Hancock, N., Lundquist, C., 2005. Rapid reworking of subtidal sediments by burrowing spatangoid urchins. Journal of Experimental Marine Biology and Ecology 321, 155-169.

Lumborg, U., Andersen, T.J., Pejrup, M., 2006. The effect of Hydrobia ulvae and microphytobenthos on cohesive sediment dynamics on an intertidal mudflat described by means of numerical modeling. Estuarine, Coastal and Shelf Science $68,208-220$.

Meysman, J.R.F., Middelburg, J.J., Heip, C.H.R., 2006. Bioturbation: A fresh look at Darwins last idea. Trends in Ecology and Evolution 21, 688-695.

McCave, I.N., 1971. Sandwaves in the North Sea off the coast of Holland. Marine Geology 10, 199-225.

Morelissen, R., Hulscher, S.J.M.H., Knaapen, M.A.F., Németh, A.A., Bijker, R., 2003. Mathematical modeling of sand wave migration and the interaction with pipelines. Coastal Engineering 48, 197-209.

Mortensen, T., 1927, Handbook of the Echinoderms of the British Isles. Oxford University Press. Oxford, $471 \mathrm{pp}$.

Mulder, J.P.M., Tonnon, P.K., 2010. Sand Engine: background and design of a meganourishment pilot in the Netherlands, Proceedings of the 32nd Conference on Coastal Engineering, Shanghai, China. 
Murray, A.B., Paola, C., 2003. Modeling the effect of vegetation on channel pattern in bedload rivers. Earth Surface Processes and Landforms 28, 131-143.

Murray, A.B., Knaapen, M.A.F., Tal, M., Kirwan, M.L., 2008. Biomorphodynamics: physical-biological feedbacks that shape landscapes. Water Resources Research 44, W11301.

Németh, A.A., Hulscher, S.J.M.H., De Vriend, H.J., 2002. Modelling sand wave migration in shallow shelf seas. Continental Shelf Research 22, 2795-2806.

Németh, A.A., Hulscher, S.J.M.H., De Vriend, H.J., 2003. Offshore sand wave dynamics, engineering problems and future solutions. Pipeline and Gas Journal $230,67-69$.

Németh, A.A., Hulscher, S.J.M.H., Van Damme, R.M.J., 2007. Modelling offshore sandwave evolution. Continental Shelf Research 27, 713-728.

Nowell, A.R.M., Church M., 1979. Turbulent flow in a depth-limited boundary layer. Journal of Geophysical Research 84, 4816-4824.

Nowell, A.R.M., Jumars, P.A., Eckman, J.E., 1981. Effects of biological activity on the entrainment of marine sediments. Marine Geology 42, 133-153.

O'Donoghue, T., Doucette, J.S., Van der Werf, J.J., Ribberink, J.S., 2006. The dimensions of sand ripples in full-scale oscillatory flows. Coastal Engineering 53, 997-1012.

Orvain, F., Sauriau, P., Bacher, C., Prineau, M., 2006. The influence of sediment cohesiveness on bioturbation effects due to Hydrobia ulvae on the initial erosion of intertidal sediments: A study combining flume and model approaches. Journal of Sea Research 55, 54-73.

Orvain, F., Le Hir, P., Sauriau, P., Lefebvre, S., 2012. Modelling the effects of macrofauna on sediment transport and bed elevation: Application over a cross-shore mudflat profile and model validation. Estuarine, Coastal and Shelf Science.

Osinga, R., Kop A.J., Malschaert, J.F.P., Van Duyl, F.C., 1997. Effects of the sea urchin Echinocardium cordatum on bacterial production and carbon flow in experimental benthic systems under increasing organic loading. Journal of Sea Research 37, 109-121.

Paarlberg, A.J., Knaapen, M.A.F., de Vries, M.B., Hulscher, S.J.M.H., Wang, Z.B., 2005. Biological influences on morphology and bed composition of an intertidal flat. Estuarine, Coastal and Shelf Science 64, 577-590.

Peralta, G., Van Duren, L.A., Morris, E.P., Bouma, T.J., 2008. Consequences of shoot density and stiffness for ecosystem engineering by benthic macrophytes in flow dominated areas: a hydrodynamic flume study. Marine Ecology Progress Series 368, 103-115.

Rabaut, M., Guilini, K., Van Hoey, G., Vincx, M., Degraer, S., 2007. A bio-engineered soft-bottom environment: The impact of Lanice conchilega on the benthic speciesspecific densities and community structure. Estuarine, Coastal and Shelf Science $75,525-536$. 
Rabaut, M., 2009. Lanice conchilega, fisheries and marine conservation: Towards an ecosystem approach to marine management. Ghent University (UGent), PhD thesis, $354 \mathrm{pp}$.

Rabaut, M., Vincx, M., Degraer, S. 2009. Do Lanice conchilega (sandmason) aggregations classify as reefs? Quantifying habitat modifying effects. Helgoland Marine Research 63, 37-46.

Reinhardt, L., Jerolmack, D., Cardinale, B.J., Vanacker, V., Wright, J., 2010. Dynamic interactions of life and its landscape: feedbacks at the interface of geomorphology and ecology. Earth Surface Processes and Landforms 35, 78-101.

Rhoads, D.C., 1974. Organism-sediment relations on the muddy sea floor. Oceanography and Marine Biology: An Annual Review 12, 263-300.

Richards, K., 1980. The formation of ripples and dunes on an erodible bed. Journal of Fluid Mechanics 99, 597618.

Rietkerk, M., Dekker S.C., De Ruiter, P.C., Van de Koppel, J. 2004. Self-Organized Patchiness and Catastrophic Shifts in Ecosystems. Science 305, 1926-1929.

Rodi, W., 1984. Turbulence models and their application in hydrodynamics: A state of the art review, Univ. of Karlsruhe, Karlsruhe, Germany.

Roos, P.C., Hulscher, S.J.M.H., 2003. Large-scale seabed dynamics in offshore morphology: Modeling human intervention. Reviews of Geophysics 41(2), 1010,

Rubin, D.M., McCulloch, D.S., 1980. Single and superimposed bedforms: a synthesis of San Francisco Bay and flume observations. Sedimentary Geology 26, 207-231.

Ryan, D.A., Brooke, B.P., Collins, L.B., Kendrick, G.A., Baxter, K.J., Bickers, A.N., Siwabessy, P.J.W., Pattiaratchi, C.B., 2007. The influence of geomorphology and sedimentary processes on shallow-water benthic habitat distribution: Esperance Bay, Western Australia. Estuarine, Coastal and Shelf Science 72, 379-386.

Sekine, M., Parker, G., 1992. Bed-load transport on transverse slope. Journal of Hydraulic Engineering 118, 513-535.

Seminara, G., 2006. Meanders. Journal of Fluid Mechanics 554, 271-297.

Soulsby, R.L., 1983. The bottom boundary layer of shelf seas. Physical Oceanography of coastal and Shelf seas. B. Johns. Amsterdam, Elsevier: 189-266.

Soulsby, R.L., 1997. Dynamics of Marine Sands: a manual for practical applications. London, Thomas Telford Publications.

Soulsby, R.L., Whitehouse, R.J.S., 2005. Prediction of ripples properties in shelf seas: Mark 2 Predictor for Time Evolution. Rep. TR 154, HR Wallingford Ltd, Wallingford UK.

Stølum, H.H., 1996. river meandering as a self-organization process. Science 271, 1710-1713. 
Sterlini, F.M., Hulscher, S.J.M.H., Hanes, D.M., 2009. Simulating and understanding sand wave variation: A case study of the Golden Gate sand waves. Journal of geophysical research 144(F02007).

Strasser, M., Pieloth, U., 2001. Recolonization pattern of the polychaete Lanice conchilega on an intertidal sand flat following the severe winter of 1995/96. Helgololand Marine Research 55, 176-191.

Tal, M., Paola, C., 2007. Dynamic single-thread channels maintained by the interaction of flow and vegetation. Geology 35, 347-350.

Talmon, A.M., Struiksma, N., Van Mierlo, M.C.L.M., 1995. Laboratory measurements of the direction of sediment transport on transverse alluvial bed slopes. Journal of Hydraulic Research 33, 495-517.

Tebble, N., 1966. British bivalve seashells. British Museum (Natural History). London, $212 \mathrm{pp}$.

Temmerman, S., Bouma, T.J., Govers, G., Wang, Z.B., De Vries, M.B., Herman, P.M.J., 2005. Impact of vegetation on flow routing and sedimentation patterns: three-dimensional modeling for a tidal marsh. Journal of Geophysical Research 110, F04019.

Temmerman, S., Bouma, T.J., Van de Koppel, J., Van der Wal, D., De Vries, M.B., Herman, P.M.J., 2007. Vegetation causes channel erosion in a tidal landscape. Geology 35, 631-634.

Terwindt, J.H.J., 1971. Sand waves in the Southern Bight of the North Sea. Marine Geology 10, 51-67.

Tobias, C.J., 1989. Morphology of sand waves in relation to current, sediment and wave data along the Eurogeul, North Sea. Report GEOPRO 1989.01, University of Utrecht, The Netherlands.

Tonnon, P.K., Van Rijn, L.C., Walstra, D.J.R., 2007. The morphodynamic modelling of tidal sand waves. Coastal Engineering 54, 279-296.

Uittenbogaard, R., 2003. Modelling turbulence in vegetated aquatic flows. In International workshop on RIParian FORest vegetated channels: hydraulic, morphological and ecological aspects, 20-22 February 2003, Trento, Italy, 2003.

Van Alphen, J.S.L.J., Damoiseaux, M.A., 1989, A geomorphological map of the Dutch shoreface and adjacent part of the continental shelf. Geol. Mijnbouw, 68, 433-444.

Van de Koppel, J., Herman, P.M.J., Thoolen, P., Heip, C.H.R., 2001. Do alternate stable states occur in natural ecosystems? Evidence from a tidal flat. Ecology 82, 3449-3461.

Van de Koppel, J., Gascoigne, J.C., Theraulaz, G., Rietkerk, M., Mooij, W.M., Herman, P.M.J., 2008. Experimental evidence for spatial self-organization and its emergent effects in mussel beds. Science 322, 739-742. 
Van de Meene, J.W.H., Van Rijn, L.C., 2000. The shoreface-connected ridges along the central Dutch coast -part 1: field observations. Continental Shelf Research 20, 2295-2323.

Van den Berg, J., Sterlini, F., Hulscher, S.J.M.H., Van Damme, R., 2012. Non-linear process based modelling of offshore sand waves. Continental Shelf Research 37, 26-35.

Van der Molen, J., 2002. The influence of tides, wind and waves on the net sand transport in the North Sea. Continental Shelf Research 22, 2739-2762.

Van der Veen, H.H., Hulscher, S.J.M.H., Knaapen, M.A.F. 2006. Grain size dependency in the occurrence of sand waves. Ocean Dynamics 56, 228-234.

Van Dijk, T.A.G.P., Kleinhans, M.G., 2007. Processes controlling the dynamics of compound sand waves in the North Sea, Netherlands. Journal of Geophysical Research.

Van Dijk, T.A.G.P., Lindenbergh, R.C., Egberts, P.J.P., 2008. Separating bathymetric data representing multiscale rhythmic bed forms: a geostatistical and spectral method compared. Journal of Geophysical Research 113, F04017.

Van Duren, L.A., Herman, P.M.J., Sandee, A.J.J., Heip, C.H.R., 2006. Effects of mussel filtering activity on boundary layer structure. Journal of Sea Research 55, $3-14$.

Van Hoey, G., 2006. Spatio-temporal variability within the macrobenthic Abra alba community, with the emphasis on the structuring role of Lanice conchilega. Ghent University (UGent), $\mathrm{PhD}$ thesis, $187 \mathrm{pp}$.

Van Hulzen, J.B., van Soelen, J., Bouma, T.B., 2007. Morphological variation and habitat modification are strongly correlated for the autogenic ecosystem engineer Spartina anglica (common cordgrass). Estuaries and Coast 30, 3-11.

Van Leeuwen, B., Augustijn, D.C.M., Van Wesenbeeck, B.K., Hulscher, S.J.M.H., De Vries, M.B., 2008. Modeling mussel bed influence on fine sediment dynamics on a Wadden Sea intertidal flat. Proceedings BioGeoCivil Engineering Conference 23-25 June 2008, Delft, the Netherlands, p. 90-98.

Van Rijn, L.C., 1991. Sediment transport in combined waves and currents, in Proceedings of Euromech 262, Balkema, A.A., Brookfield, Vt.

Van Rijn, L.C., 1993. Principles of sediment transport in rivers, estuaries and coastal seas. Amsterdam, Aqua publications.

Van Rijn, L.C., Walstra, D. J. R., van Ormondt, M., 2004. Description of TRANSPOR 2004 (TR2004) and implementation in DELFT3D online, Rep. Z3748, Delft Hydraul., Delft, Netherlands.

Van Rijn, L.C., 2007. Unified view of sediment transport by currents and waves. II: Suspended transport, Journal of Hydraulic Engineering 133, 668-689. 
Van Santen, R.B., de Swart, H.E., van Dijk, T.A.G.P., 2011. Sensitivity of tidal sand wavelength to environmental parameters: A combined data analysis and modeling approach. Continental Shelf Research 31, 966-978.

Verboom, G.K., Slob, A., 1984. Weakly-reflective boundary conditions for 2D water flow problems. Advances in Water Resources 7, 192-197.

Verfaillie, E., Van Lancker, V., Van Meirvenne, M., 2006. Multivariate geostatistics for the predictive modeling of the surficial sand distribution in shelf seas. Continental Shelf Research 26, 2454-2468.

Verfaillie, E., 2008. Development and validation of spatial distribution models of marine habitats, in support of the ecological valuation of the seabed. $\mathrm{PhD}$ thesis, Ghent University, Belgium.

Weerman E.J., Van de Koppel, J., Eppinga, M.B., Montserrat, F., Liu, Q.X., Herman, P.M.J., 2010. Spatial self-organization on intertidal mudflats through biophysical stress divergence. American Naturalist 176, 15-32.

Werner, B.T., 1999 Complexity in natural landform patterns. Science 284, 102-104.

Werner, B.T., Fink, T.M., 1993. Beach cusps as self-organised patterns. Science 260, 968-971.

Widdows, J., Brinsley, M.D., 2002. Impact of biotic and abiotic processes on sediment dynamics and the consequences to the structure and functioning of the intertidal zone. Journal of Sea Research 48, 143-156.

Widdows, J., Brinsley, M.D., Bowley, N., Barrett, C., 1998. A benthic annular flume for in situ measurement of suspension feeding/biodeposition rates and erosion potential of intertidal cohesive sediments. Estuarine, Coastal and Shelf Science $56,27-38$.

Widdows, J., Brinsley, M.D., Salkeld, P.N., Lucas, C.H., 2000. Influence of biota on spatial and temporal variation in sediment erodability and material flux on a tidal flat (Westerschelde, The Netherlands). Marine Ecology Progress Series 194, 23-37.

Willems, W., Goethals, P., Van den Eynde, D., Van Hoey, G., Van Lancker, V., Verfaillie, E., Vincx, M., Degraer, S., 2008. Where is the worm? Predictive modelling of the habitat preferences of the tube-building polychaete Lanice conchilega. Ecological Modelling 212, 74-79.

Ziegelmeier V.E., 1952. Beobachtungen über den Rhrenbau von Lanice conchilega (Pallas) im Experiment und am natürlichen Standort. Helgoländer Wissenschaftliche Meeresuntersuchungen, pp 108-129. 


\section{List of publications}

\section{Peer reviewed journal papers}

1. Borsje, B.W., Kranenburg, W.M., Roos, P.C., Jordan, M., Hulscher, S.J.M.H., 2012. The role of suspended sediment in the occurrence of tidal sand waves, under review. (Chapter 3)

2. Borsje, B.W., Roos, P.C., Kranenburg, W.M., Hulscher, S.J.M.H., 2012. Modeling sandwave evolution in a numerical shallow water model, under review. (Chapter 2)

3. Borsje, B.W., Bouma, T.J., Rabaut, M., Herman, P.M.J., Hulscher, S.J.M.H., 2012. Creation and degradation rates of biogeomorphological structures: a study on the tube-building polychaete Lanice conchilega, under review. (Chapter 6)

4. Borsje, B.W., Cronin, K., Holzhauer, H., De Mesel, I., Ysebaert, T., Hibma, A., 2012. Biogeomorphological interactions on a nourished tidal flat: lessons learned on building with nature. Aqua et Terra 126, 1-10.

5. Borsje, B.W., van Wesenbeeck, B., Dekker, F., Paalvast, P., Bouma, T.J., de Vries, M.B., 2011. How ecological engineering can serve in coastal protection - a review. Ecological Engineering 37, 113-122. doi: 10.1016/j.ecoleng.2010.11.027.

6. Borsje, B.W., De Vries, M.B., Hulscher, S.J.M.H., Herman, P.M.J., 2009. On the parameterization of biological activity on sandwave and sandbank dynamics. Ocean Dynamics 59, 659-670. doi: 10.1007/s10236-009-0199-0. (Chapter 5).

7. Borsje, B.W., Buijsman, M.C., Besio, G., De Vries, M.B., Hulscher, S.J.M.H., Herman, P.M.J., Ridderinkhof, H., 2009. On the modelling of bio-physical influences on seasonal variation in sandwave characteristics. Journal of Coastal Research 56, 698-702. (Chapter 7)

8. Borsje, B.W., De Vries, M.B., Bouma, T.J., Besio, G., Hulscher, S.J.M.H., Herman, P.M.J., 2009. Modelling bio-geomorphological influences for offshore sand waves. Continental Shelf Research 29, 1289-1301. doi: 10.1016 / j.csr.2009.02.008. (Chapter 4)

9. Borsje, B.W., De Vries, M.B., Hulscher, S.J.M.H., De Boer, G.J, 2008. Modeling large-scale cohesive sediment transport with the inclusion of small-scale biological activity. Estuarine, Coastal and Shelf Science 78, 468-480. doi: 10.1016 / j.ecss.2008.01.009. 


\section{Conference papers}

1. Hulscher, S.J.M.H., Matthieu, J., Borsje, B.W., Sterlini, F., 2012. Improving sand wave heigth predicitons in a numerical model. ICCE 2012.

2. Borsje, B.W., Hulscher, S.J.M.H., Herman, P.M.J., 2012. Self-organization in the underwater landscape: exploring bio-physical interactions in tidal sand wave fields. ICCE 2012. (Chapter 8)

3. Cronin, K., Borsje, B.W., Morphological modelling of a tidal flat nourishment in the Eastern Scheldt, The Netherlands. JONSMOD 2012.

4. Borsje, B.W., P.C. Roos, W.M. Kranenburg, S.J.M.H. Hulscher, 2011. Modeling sandwave formation in a numerical shallow water model, In: Shao, X., Z. Wang \& G. Wang. RCEM 2011, 7th IAHR symposium on River, Coastal and Estuarine Morphodynamics, Beijing, China.

5. Elizondo Garcia, F.A., D.C.M. Augustijn, Borsje, B.W., R.S.E.W. Leuven, 2011. Do invasive benthic mollucs impact river morphology? In: E. Mostert, L.J.E. Bouaziz (Eds.) NCR-Days 2011: Controlling the Dutch Rivers, Book of Abstracts, p. 18-19.

6. De Vries, M.B., Borsje, B.W., De Vriend, H.J., 2011. Understanding biogeomorphological interactions as basis for building with living nature. In: (Eds). Proceedings of the NCK-days 2011, Texel, The Netherlands, pp. 30.

7. Borsje, B.W., van Wesenbeeck, B., Dekker, F., Paalvast, P., Bouma, T.J., van Katwijk, M.M., de Vries, M.B., 2010. How ecological engineering can serve in coastal defence strategies. In: (Eds). Proceedings of the NCK-days 2010, Zeeland, The Netherlands, pp. 30.

8. Borsje, B.W., Van der Werf, J.J., Kruijt, M.A., Hulscher, S.J.M.H., Herman, P.M.J., Modeling biogeomorphological interactions for the Dutch sandy coast. Submitted for the 32nd International Conference on Coastal Engineering (ICCE), Shanghai, China.

9. Borsje, B.W., Buijsman, M.B., Besio, G., De Vries, M.B., Hulscher, S.J.M.H., Herman, P.M.J., Ridderinkhof, H., 2009. Modelling bio-physical influences on sandwave dynamics. In: Baptist, M.J. (Ed). Proceedings of the NCK-days 2009, Texel, The Netherlands, pp. 30.

10. Borsje, B.W., Buijsman, M.C., Besio, G., Hulscher, S.J.M.H., Herman, P.M.J., Ridderinkhof, H., 2009. Bio-geomorphological interactions in sandwave migration. In: Vionnet, C.A., Garcia, M.H., Latrubesse, E.M., Perillo, G.M.E. (Eds). Proceedings of the sixth IAHR Symposium on River, Coastal and Estuarine Morphodynamics (RCEM), Santa Fe, Argentina, pp. 567-574.

11. Borsje, B.W., Bouma, T.J., De Vries, M.B., Hulscher, S.J.M.H., Herman, P.M.J., Besio, G., 2009. Bio-geomorphological interactions in offshore seabed patterns. In: McKee Smite, J. (Eds). Proceedings of the 31st International Conference on Coastal Engineering (ICCE), Hamburg, Germany, pp. 4423-4435. 
12. Besio, G., Borsje, B.W., 2008. Influenza degli organismi bentonici sulla formazione di sand waves: la lunghezza d'onda. Atti XXXI Convegno di Idraulica e Costruzioni Idrauliche, Perugia, Italy, 9-12 Settembre, 8 pp (In Italian).

13. De Vries, M.B., Borsje, B.W., 2008. Organisms influence fine sediment dynamics on basin scale. In: Souza, A.J. (Eds). PECS, Liverpool, England, pp. 103-106.

14. Borsje, B.W., De Vries, M.B., Hulscher, S.J.M.H., Herman, P.M.J., 2008. On the parameterization of biological activity on sandwave and sandbank dynamics. In: Souza, A.J. (Eds). PECS, Liverpool, England, pp. 19-22.

15. Borsje, B.W., Besio, G., Hulscher, S.J.M.H., Blondeaux, P., Vittori, G., 2008. Exploring biological influences on offshore sandwave length. In: Parsons D.R., Garlan T., Best J.L. (Eds). Proceedings of Marine and River Dune Dynamics III (MARID), Leeds, England, pp. 31-38.

16. De Vries, M.B., Borsje, B.W., 2007. Species response to climate change could affect the fate of fine sediment in the Wadden Sea. In: Dohmen-Janssen, C.M., Hulscher, S.J.M.H. (Eds). Proceedings of the fifth IAHR Symposium on River, Coastal and Estuarine Morphodynamics (RCEM), Enschede, The Netherlands, pp. 299-305.

17. Borsje, B.W., Hulscher, S.J.M.H., De Vries, M.B., De Boer, G.J., 2007. Modeling large scale biological influences on morphodynamics in estuaries. In: DohmenJanssen, C.M., Hulscher, S.J.M.H. (Eds). Proceedings of the fifth IAHR Symposium on River, Coastal and Estuarine Morphodynamics (RCEM), Enschede, The Netherlands, pp. 255-262.

18. De Vries, M.B., Borsje, B.W., 2007. Basin shape and erodibility determinants for the longer term development of estuaries? In: Hoekstra, P. (Ed), Proceedings of the 15th Anniversary NCK International symposium, IJmuiden, The Netherlands, pp. 35 . 


\section{About the author}

Bas Borsje was born in Ede, The Netherlands, on 16 June 1983. He grew up in Bennekom, Eethen and Vriezenveen, the Netherlands. He finished secondary education (HAVO) in 1999 at Noordik Scholengemeenschap in Almelo. One year later, he received his Atheneum diploma at the same school. Bas Borsje started studying Civil Engineering and Management in 2001 at the University of Twente, Enschede, The Netherlands. In 2006 he finished his study cum laude with a master thesis on the modeling of biological influences on sediment dynamics. He conducted his master thesis at WL|Delft Hydraulics, Delft, The Netherlands. After his graduation, Bas started working at WL|Delft Hydraulics. From 1 November 2009 he started his $\mathrm{PhD}$ research (0.8 fte), while he kept

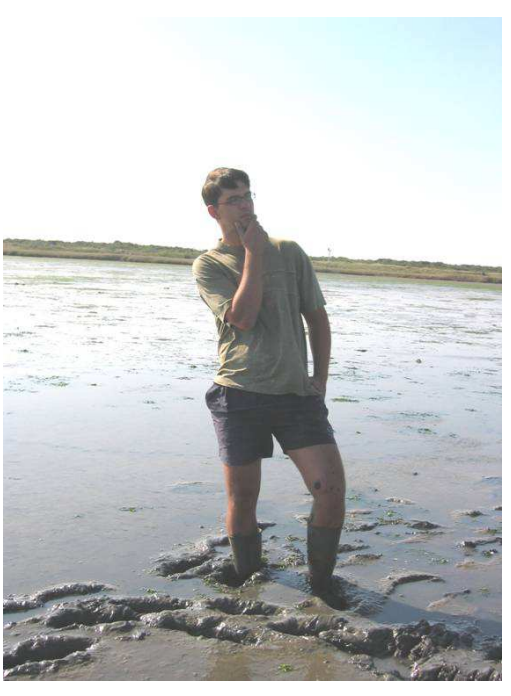
working for WL|Delft Hydraulics (0.2 fte), which merged into Deltares. Following the $\mathrm{PhD}$ defense in October 2012, Bas continues to work as advisor at Deltares, and as researcher at the University of Twente. 